\title{
Facilities Condition and Hazards Assessment for Materials and Fuel Complex Facilities MFC- 799, 799A, and 770C
}

November 2009

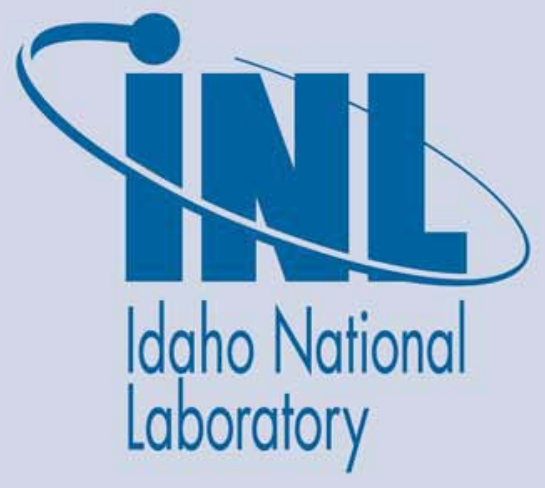

The INL is a U.S. Department of Energy National Laboratory operated by Battelle Energy Alliance 
INL/EXT-09-17292

\title{
Facilities Condition and Hazards Assessment for Materials and Fuel Complex Facilities MFC-799, 799A, and $770 \mathrm{C}$
}

November 2009

\author{
Idaho National Laboratory \\ Idaho Falls, Idaho 83415
}

http://www.inl.gov

Prepared for the

U.S. Department of Energy

Office of Nuclear Energy

Under DOE Idaho Operations Office

Contract DE-AC07-05ID14517 


\section{DISCLAIMER}

This information was prepared as an account of work sponsored by an agency of the U.S. Government. Neither the U.S. Government nor any agency thereof, nor any of their employees, makes any warranty, expressed or implied, or assumes any legal liability or responsibility for the accuracy, completeness, or usefulness, of any information, apparatus, product, or process disclosed, or represents that its use would not infringe privately owned rights. References herein to any specific commercial product, process, or service by trade name, trade mark, manufacturer, or otherwise, does not necessarily constitute or imply its endorsement, recommendation, or favoring by the U.S. Government or any agency thereof. The views and opinions of authors expressed herein do not necessarily state or reflect those of the U.S. Government or any agency thereof. 



\section{ABSTRACT}

The Materials and Fuel Complex (MFC) facilities MFC-799, Sodium Processing Facility (a single building consisting of two areas: the Sodium Process Area and the Carbonate Process Area); MFC-799A, Caustic Storage Area; and MFC-770C, Nuclear Calibration Laboratory, have been declared excess to future Department of Energy Office of Nuclear Energy mission requirements. Transfer of these facilities from NE to the Department of Energy Office of Environmental Management, and an associated schedule for doing so, have been agreed upon by the two offices. The prerequisites for this transfer are removal of nonexcess materials and chemical inventory, deinventory of the calibration source in MFC-770C, and rerouting or isolation of utility and service systems.

This report provides a description of the current physical condition and any hazards (material, chemical, nuclear, or occupational) that may be associated with past operations of these facilities. This information will document the conditions at the time of transfer of the facilities from the Office of Nuclear Energy to the Office of Environmental Management and will serve as the basis for disposition planning. The process used in obtaining this information included document searches, interviews, and facility walk-downs.

MFC-799, 799A, and 770C are all structurally sound and associated hazardous or potentially hazardous conditions are well defined and well understood. All installed equipment items (e.g., tanks and filters) used to process hazardous materials remain in place and appear to have maintained their integrity. There is no evidence of leakage and all openings are properly sealed or closed off and connections are sound. The pits appear clean with no evidence of cracking or deterioration that could lead to migration of contamination.

Based on the available information/documentation reviewed and the overall conditions observed during the facility walk-downs, it is concluded that these facilities may be disposed of at minimal risk to human health and safety and the environment. 


\section{CONTENTS}

ABSTRACT

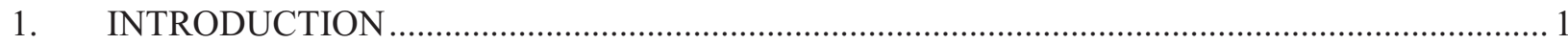

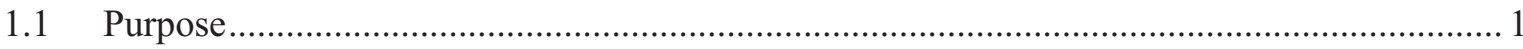

1.2 Location and Boundaries of Facilities Being Transferred ................................................ 1

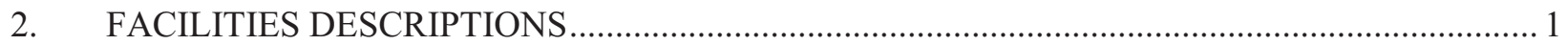

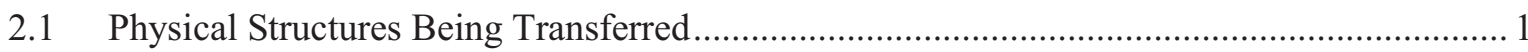

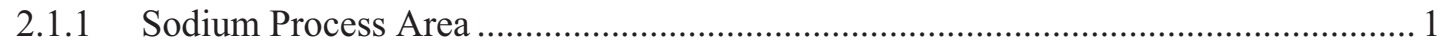

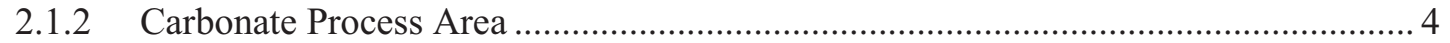

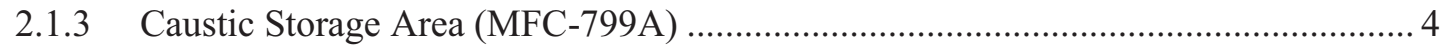

2.1.4 Nuclear Calibration Laboratory (MFC-770C) ….................................................... 4

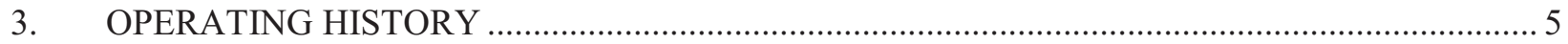

3.1 Sodium Process Facility Basic Process Description ......................................................... 5

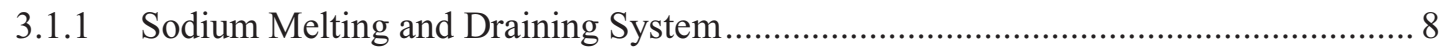

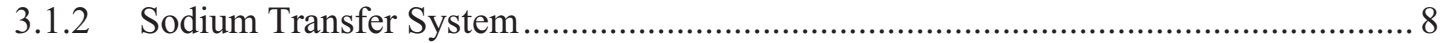

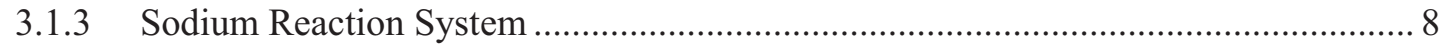

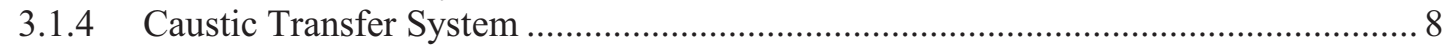

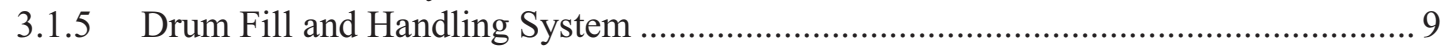

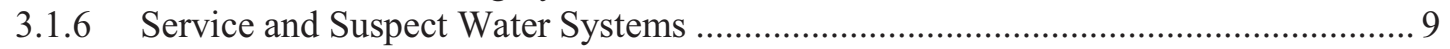

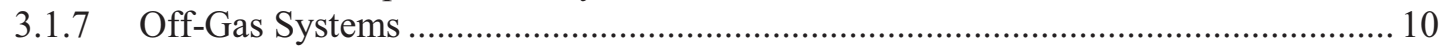

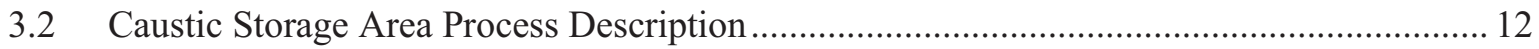

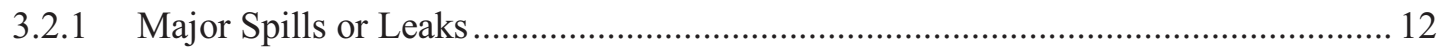

3.3 Nuclear Calibration Laboratory Basic Process Description............................................. 12

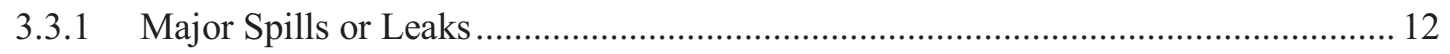

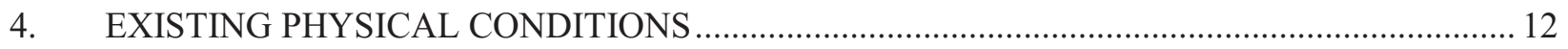

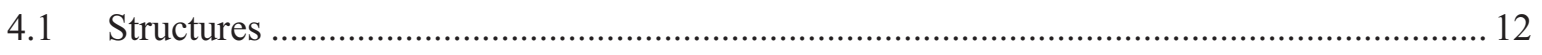

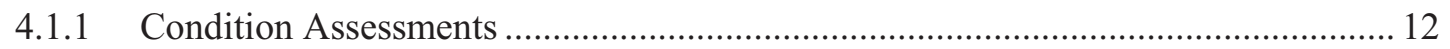

4.1.2 Engineered Protective Barriers and Systems ........................................................ 12

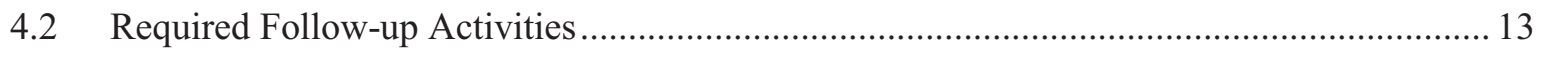

5. EXISTING HAZARDOUS RADIOLOGICAL AND CHEMICAL CONTAMINATION............. 13 


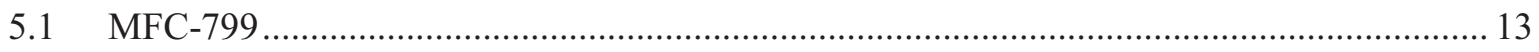

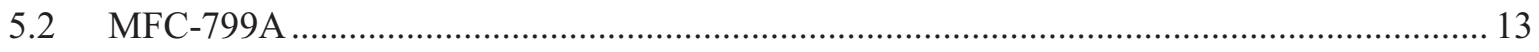

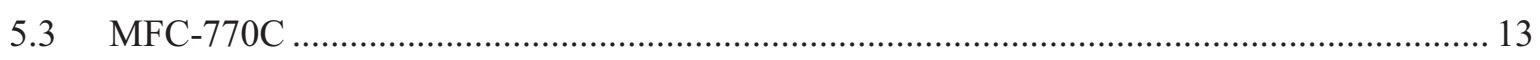

6. SPECIAL NUCLEAR AND FISSIONABLE MATERIALS INVENTORY ............................... 13

7. HAZARDOUS MATERIALS, WASTE, AND CHEMICAL INVENTORIES ............................ 14

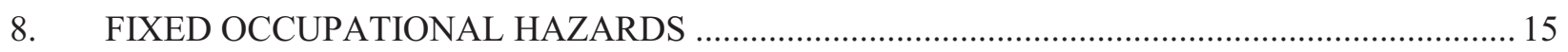

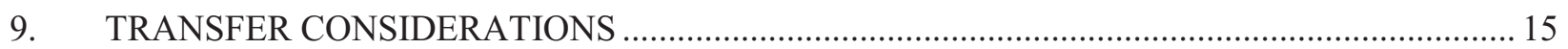

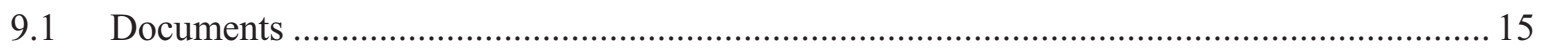

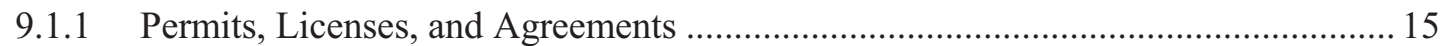

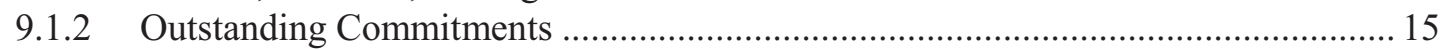

9.1.3 Excess Equipment and Material..................................................................... 15

9.2 Stabilization and Other Required Actions Required for Transfer...................................... 16

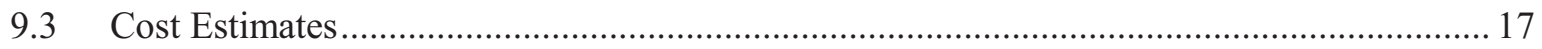

10. SUMMARY, CONCLUSIONS, AND RECOMMENDATIONS ….......................................... 18

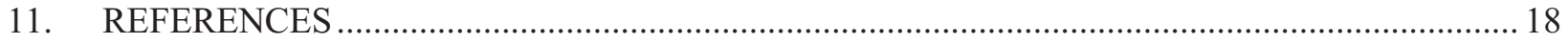

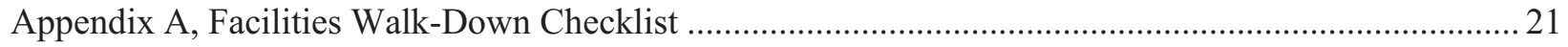

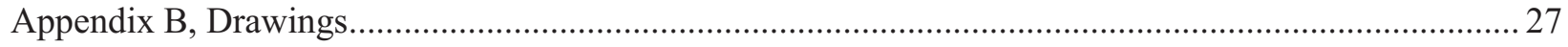

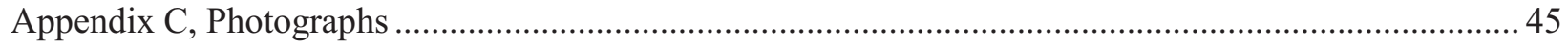

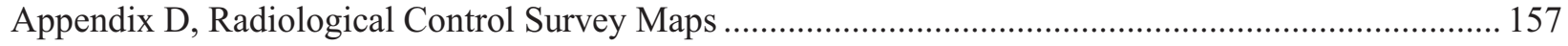

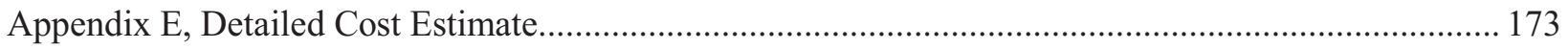

\section{FIGURES}

1. Location of facilities being transferred at the Materials and Fuels Complex ...........................2

\section{TABLES}

1. Sodium Processing Facility summary operations details .................................................. 6

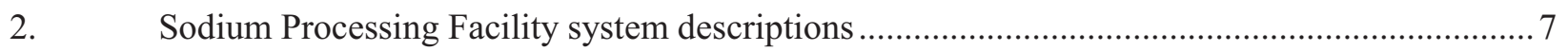

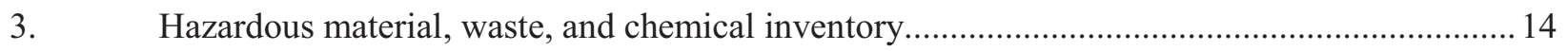

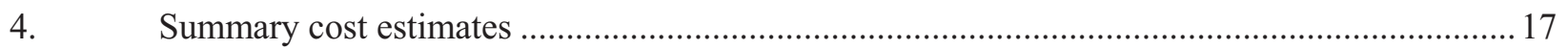




\section{ACRONYMS}

DOE Department of Energy

EBR-II Experimental Breeder Reactor-II

EM Office of Environmental Management (DOE)

HEPA high-efficiency particulate air

INL Idaho National Laboratory

MFC Materials and Fuels Complex

$\mathrm{Na} \quad$ sodium

NaK sodium-potassium

NE Office of Nuclear Energy (DOE)

RCRA Resource Conservation and Recovery Act 


\section{Facilities Condition and Hazards Assessment for Materials and Fuel Complex Facilities MFC-799, 799A, and $770 \mathrm{C}$}

\section{INTRODUCTION}

\subsection{Purpose}

The purpose of this report is to provide a detailed description of the Materials and Fuel Complex (MFC) facilities MFC-799, Sodium Processing Facility (a single building consisting of two areas: the Sodium Process Area and the Carbonate Process Area); MFC-799A, Caustic Storage Area; and MFC-770C Nuclear Calibration Laboratory. It also provides details of their current physical condition and any hazards (material, chemical, nuclear, or occupational) that may be associated with past operations. This information will document the conditions at the time of transfer of the facilities from the U.S. Department of Energy (DOE) Office of Nuclear Energy (NE) to the DOE Office of Environmental Management (EM) and will serve as the basis for disposition planning. The process used in obtaining this information included document searches, interviews, and facility walk-downs. A copy of the facility walk-down checklist is included in Appendix A of this report.

\subsection{Location and Boundaries of Facilities Being Transferred}

These structures as shown in Figure 1 are all part of or adjacent to the Sodium Processing Facility (SPF), which is located in the northwest corner of the MFC complex at the Idaho National Laboratory (INL) and are fairly isolated from the adjoining structures and facilities.

\section{FACILITIES DESCRIPTIONS}

\subsection{Physical Structures Being Transferred}

The Sodium Processing Facility (Building MFC-799) consists of one building with two designated areas used for hazardous waste/mixed waste container and tank storage, repackaging, and treatment. The two areas are the Sodium Process Area and the Carbonate Process Area. MFC-799A, Caustic Storage Area, consists of a single building containing a caustic storage tank over a spill containment pit and associated piping and pumping equipment. A separate exterior carbonate storage tank rests on a concrete pad next to the building. The Nuclear Calibration Laboratory (MFC-770C) is a 240- $\mathrm{ft}^{2}$ single structure that is not directly associated with the operations or function of the Sodium Processing Facility. However, it is adjacent to these facilities and excess to mission requirements. Therefore, it is included in this transfer as a matter of efficiency. Descriptions of each building are provided in the following subsections.

\subsubsection{Sodium Process Area}

The Sodium Process Area was used for storage and treatment of hazardous waste/mixed waste in both containers and tanks. This area consists of an original four-roomed, L-shaped structure. An enclosed and covered, carbon steel-lined, concrete pad was later constructed where process equipment is located. The building is supported on a thickened-edge, reinforced-concrete pad. Three rooms in the Sodium Process Area were used for hazardous waste/mixed waste storage and treatment: the Barrel Holding Room, Sodium Melting and Draining Room, and Sodium Process Equipment Room. The fourth room is the Sodium Processing Facility Control Room. Each of these rooms is described briefly in the following subsections. Approximate overall dimensions of the enclosed Sodium Process Area are $65 \times 57 \mathrm{ft}$. Most 
of the exterior of the Sodium Processing Facility is constructed of galvanized-steel siding and roof panels on a structural steel frame. However, the Sodium Melting and Draining Room (the central room along the north wall) has 12 -in. thick reinforced-concrete block walls and an 8-in. thick reinforced-concrete slab roof.

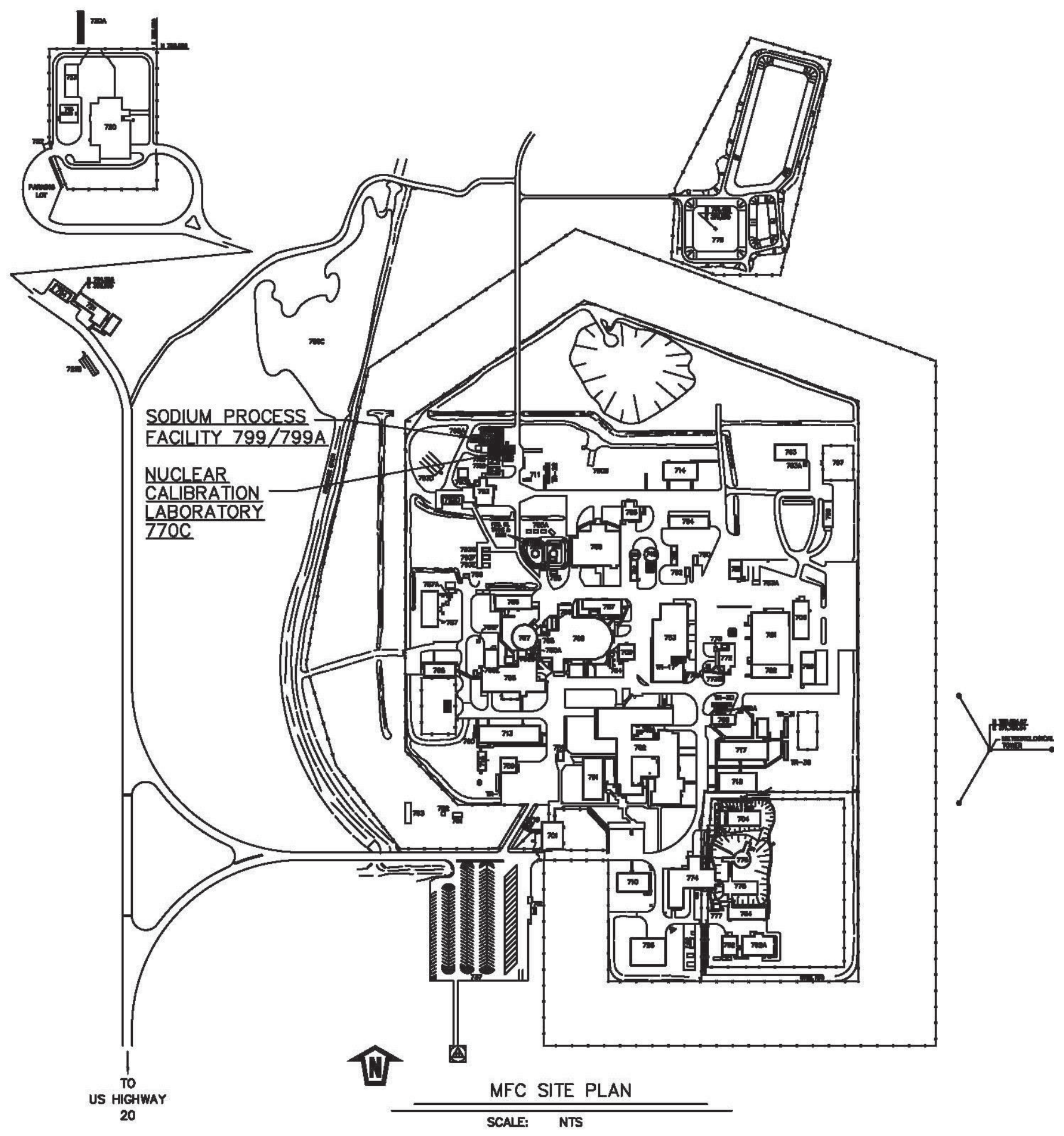

Figure 1. Location of facilities being transferred at the Materials and Fuels Complex. 
2.1.1.1 Barrel Holding Room. The Barrel Holding Room was used to receive (store up to) 32 drums of hazardous waste/mixed waste. The dimensions of the room are $20 \mathrm{ft} 6 \mathrm{in} . \times 25 \mathrm{ft}$. The hazardous waste/mixed waste was brought into this area through a $10 \times 10-\mathrm{ft}$ sliding service door (east exterior wall), removed from the skid where they were received, and placed onto individual barrel dollies. Once placed on the dollies, the drums were moved into the Sodium Melting and Draining Room (the Sodium Processing Facility typically processed sodium $[\mathrm{Na}]$ and sodium-potassium $(\mathrm{NaK})$ alloy waste, but was permitted to process other alkali metals) through a $6 \times 6$-ft sliding door on the west wall of the Barrel Holding Room. In addition, the Barrel Holding Room also was the pathway for removal of the drained drums from the Sodium Melting and Draining Room as discussed in the next section. A 1,000-lb lift capacity jib crane is available for moving full drums (as needed) for sodium processing activities and maintenance support.

2.1.1.2 Sodium Melting and Draining Room. The Sodium Melting and Draining Room was used to melt and drain drums of alkali metal hazardous waste/mixed waste. The dimensions of the room are $25 \times 22 \mathrm{ft}$. There were eight barrel container assemblies used to hold the drums of hazardous waste/mixed waste (typically $\mathrm{Na}$ and $\mathrm{NaK}$ ) while they melted and drained. There is a bridge crane used to transfer the drums into the barrel container assemblies. The crane has a capacity of $1,000 \mathrm{lb}$ and coverage of $15 \mathrm{ft}$ laterally and $18 \mathrm{ft}$ along the rail. The barrel container assemblies are arranged in two banks of four. A barrel draining manifold, which is insulated, served each of the two banks of four barrel assemblies. A flexible, stainless-steel line is provided at each barrel container assembly to connect the drum to the manifold. Each manifold (Manifold "A" on north side, Manifold "B" on south) is constructed of 3/4-in., Series-300, stainless steel pipe. A nitrogen purge is provided for each of the flexible barrel drain lines. The two barrel draining manifolds are combined into an insulated 1-in., Series-300, stainless-steel pipe, and, in turn, connected to the 5,000-gal sodium storage tank. The manifolds and 1-in. pipe are all sloped to drain into the 5,000-gal sodium storage tank. One drum can be drained through each manifold simultaneously.

2.1.1.3 Sodium Process Equipment Area. The Sodium Process Equipment Area was used to store and treat alkali metal hazardous waste/mixed waste. There are several major components in the sodium process area, including a 5,000-gal sodium storage tank, two 730-gal sodium day tanks (Tank A on west side, Tank B on east), sodium reaction vessel, 1,000-gal caustic cooling tank, 4,000-gal caustic storage tank, and the caustic off-gas system. The dimensions of the area are approximately $20 \times 57 \mathrm{ft}$ in an L-shaped configuration. The process area floor is a concrete pad and the process area secondary containment pits are lined with welded 3/16-in. carbon-steel plate. The building is supported on a thickened-edge, reinforced-concrete pad.

The sodium storage tank is a carbon-steel tank that received alkali metal from the barrel drain stations. The storage tank filled the day tanks, which fed the alkali metal to the reaction vessel at a rate of approximately 0.75 to $1.0 \mathrm{gal} / \mathrm{min}$. The reaction vessel converted the alkali metal to a liquid hydroxide waste form, which was then loaded into drums and allowed to cool to solidify. The caustic cooling tank and the caustic storage tank allowed for storage of caustic during reaction vessel shutdowns. The caustic storage tank was used for backup storage only. The caustic storage tank is located in a separate building (MFC-799A) just west of the Sodium Process Equipment Area.

The caustic off-gas system is composed of several components designed to remove moisture, entrained caustic, and caustic vapor, and provides a vent path for hydrogen from the reaction vessel. The caustic off-gas system is located on the wall, in the southwest corner of the Sodium Process Equipment Area.

2.1.1.4 Control Room. The dimensions of the Control Room are approximately $20 \times 10 \mathrm{ft}$. The Sodium Processing Facility Control Room houses the control computer and input/output front-end computer. An 
operator was in attendance whenever the process system was in operation. The control computer was programmed to provide the control and operator interface for the Sodium Processing Facility that allowed control of system pressures, valves, temperatures, and so forth. More detailed information as to interlocks, pressure, level, and temperature controls is provided in Appendix A, the process description, and Subsection D-2(d) of the Resource Conservation and Recovery Act (RCRA) Permit.

The primary power distribution panel is located in the control room. It should be noted that this power distribution panel is used for the main power distribution to the Radioactive Waste Storage Facility, which is located about $800 \mathrm{ft}$ to the northeast of the Sodium Processing Facility. The Radioactive Waste Storage Facility is a Security Category 1 facility; therefore, the power must be maintained and controlled at all times.

\subsubsection{Carbonate Process Area}

The Carbonate Process Area is an addition to the Sodium Processing Facility and is adjoined to the original structure to the south. Doors allow access between the original Sodium Processing Facility and the Carbonate Process Area. The Carbonate Process Area accommodated equipment for filling drums and provided storage of the hydroxide solution while it solidified. The Carbonate Process Area includes approximately $23 \times 25 \mathrm{ft}$ of main processing area with an associated upper mezzanine level and a shielded staging area of approximately $17 \times 16 \mathrm{ft}$.

The building height in the main processing and staging areas is approximately $31 \mathrm{ft}$. The other wing of the L-shaped structure adds approximately $30 \times 72 \mathrm{ft}$ of drum storage and handling area with room for forklift operations. There are two 5-ton trolley cranes in this area that were used for supporting maintenance operations. The building height in the second wing is approximately $12 \mathrm{ft}$. The building is placed on a reinforced-concrete pad capable of supporting a uniform live load of $500 \mathrm{lb} / \mathrm{ft}^{2}$. All sections of the Sodium Processing Facility meet the requirements of the UBC and Seismic Zone 2 or 2B.

Storage of empty and filled hydroxide drums was provided by two storage bays in the southeast area of the Carbonate Process Area. The storage bays are placed on a reinforced concrete pad with cinder block walls. Roll-up doors provide access to the Carbonate Process Area side of each bay, and an external roll-up door is available on the west bay. Permanent carbon-steel pans provided secondary containment for the liquid caustic drums stored in the bays. Poly platforms were placed inside the pans to allow forklift operation in the secondary containment areas and to elevate the caustic drums off the floor.

\subsubsection{Caustic Storage Area (MFC-799A)}

The Caustic Storage Area is a pre-engineered metal building that was added as part of the 1996 Sodium Processing Facility upgrade in support of the Experimental Breeder Reactor-II (EBR-II) shutdown. This conversion is discussed in detail in the following subsection. The facility is a single story, single room structure used to house a 4,000-gal storage tank within a containment pit and the associated piping and pumping equipment. There also is an external storage tank located on a concrete pad adjacent to the building. The exterior storage tank was never used.

\subsubsection{Nuclear Calibration Laboratory (MFC-770C)}

The Nuclear Calibration Laboratory is a $240-\mathrm{ft}^{2}$, single story facility constructed in the mid-1960s. MFC-770C houses a JL Sheperd Model 81-12 Beam Calibrator (Serial No. 540) and Model 155 Attenuator System (Serial No. 783), as well as a Cs-137 Source. This Cs-137 source was validated to be $200 \mathrm{Ci}$ on August 19, 1975. Based on a 30.3-year half-life, the Cs-137 Source should be approximately 94 $\mathrm{Ci}$ in strength. 


\section{OPERATING HISTORY}

\subsection{Sodium Process Facility Basic Process Description}

The Sodium Processing Facility was originally designed and built in the 1980s for reacting the $290 \mathrm{~m}^{3}$ (77,000 gal) of primary sodium from the Fermi-1 Reactor in Detroit, Michigan, into a $50 \mathrm{wt} \%$ sodium hydroxide solution. This solidified sodium had been stored in 55-gal drums at Argonne National Laboratory-West (is now MFC) near Idaho Falls, Idaho since the early 1970s.

The sodium hydroxide was scheduled to be used to neutralize acid produced in the PUREX process at the Hanford site in Washington State. Because of a change in the PUREX mission, the sodium hydroxide was no longer required and the mission was abandoned before the Sodium Processing Facility became operational.

With the shutdown of EBR-II, the necessity for a facility for reacting the primary and secondary sodium was identified. In 1996, Argonne National Laboratory-West engineering and operations undertook the task of upgrading the existing Sodium Processing Facility to convert the sodium hydroxide to a dry, nonhazardous sodium carbonate waste that is acceptable for burial in the State of Idaho. Using thin film evaporator technology, the $50 \mathrm{wt} \%$ sodium hydroxide was combined with carbon dioxide in the reaction section of the thin film evaporator to form sodium carbonate product and water.

The sodium carbonate product and water were heated in the evaporation section of the thin film evaporator to remove the water and dry the sodium carbonate product into a powder. After testing the thin film evaporator for approximately 1 year, it was determined that this technology was not suitable due to plugging of equipment, minimal throughput, and powder containment issues. In 1998, it was decided to convert the sodium to a $70 \mathrm{wt} \%$ sodium hydroxide, a substance that solidifies at $65^{\circ} \mathrm{C}\left(150^{\circ} \mathrm{F}\right)$ and is acceptable for burial in Idaho.

The Sodium Processing Facility was modified and initial testing of the new process was successfully completed in November 1998 with nonradioactive sodium. Full production operations with FERMI sodium began on December 20, 1998.

Sodium could be introduced into the Sodium Processing Facility from two sources. The first source was the 208-L (55-gal) FERMI-1 barrels, which were melted and drained at the Sodium Processing Facility. The second source was the EBR-II primary and secondary sodium, which was transferred to the Sodium Processing Facility through a transfer line. The sodium was then injected into a nickel reaction vessel into a $70 \mathrm{wt} \%$ solution of sodium hydroxide. Water also was injected, maintaining the $70 \mathrm{wt} \%$ concentration by controlling the boiling point of the solution.

The sodium hydroxide was transferred from the reaction vessel into specially fabricated 269-L (71-gal) square drums, four to a pallet, and allowed to cool. The square drums occupied the same volume as the standard 208-L (55-gal) cylindrical drums; however, the square drums maximized utilization of the space on a pallet, minimizing the landfill space required for disposal. As part of the hazardous waste permit, daily drum samples were required to ensure solid sodium hydroxide was produced.

After completion of the secondary sodium processing, drum sampling revealed some liquid in drums that should have been solid. Upon investigation, it was determined that the liquid was due to inadvertent water addition into the reaction vessel, which diluted the sodium hydroxide concentration. In addition, the process was operated at temperatures that were too low, causing the sodium hydroxide concentration to fall below $69 \mathrm{wt} \%$ (the sodium hydroxide monohydrate crystallization concentration). At the lower sodium hydroxide concentration, not all of the solution solidifies at nominal ambient temperatures. 
The Sodium Processing Facility was shutdown in August 1999 to undergo upgrades to the process to ensure the cooled product drums solidify and liquid is not present. Process system upgrades included increasing the operating temperature from $177^{\circ} \mathrm{C}\left(350^{\circ} \mathrm{F}\right)$ to $191^{\circ} \mathrm{C}\left(375^{\circ} \mathrm{F}\right)$ and installing physical and computer controls to prevent inadvertent water addition. During this shutdown, modifications to the off-gas system also were performed. Sodium hydroxide carryover in the off-gas system attacked the borosilicate glass high-efficiency particulate air (HEPA) filters and required replacement after approximately 7 days. Off-gas system modifications included changing the HEPA filter media to Teflon, which is resistant to sodium hydroxide, and installing parallel HEPA filters to increase the operating time between HEPA filter changeouts.

The sodium was scheduled to be processed in five separate and distinct campaigns, based on their radiation levels. The FERMI-1 and EBR-II secondary sodium contained only low levels of radiation, while the EBR-II primary sodium had radiation levels of approximately 40 millirem per hour at 1 meter. Approximately $145 \mathrm{~m}^{3}$ (38,000 gal) of FERMI-1 primary sodium was processed initially to gain operator experience with the least radioactive sodium. Second, all of the $50 \mathrm{~m}^{3}$ (13,000 gal) EBR-II secondary sodium was processed. Next, approximately 106 to $125 \mathrm{~m}^{3}$ (28,000 to 33,000 gal) of FERMI-1 primary sodium was processed to validate modifications made to the Sodium Processing Facility. This was scheduled to start in June 2000. Fourth, all of the $330 \mathrm{~m}^{3}$ (87,000 gal) of EBR-II primary sodium was processed. Finally, the remaining FERMI-1 primary sodium, approximately 20 to $39 \mathrm{~m}^{3}$ (5,000 to 10,000 gal) was processed as a flush of the Sodium Processing Facility systems.

In March 2001, the Sodium Processing Facility was placed in standby pending decisions on sodium treatment associated with the Remote Treatment Project/Remote-Handled Waste Disposition Project.

Table 1 summarizes the information related to materials handled and the various vessels used in the conversion of sodium to sodium hydroxide.

Table 1. Sodium Processing Facility summary operations details.

\begin{tabular}{|l|l|}
\hline Allowed Waste Types & $\begin{array}{l}\text { Sodium Processing Facility Sodium Storage Tank: Ignitable reactive, corrosive, or } \\
\text { toxic metal waste: Na NAK, NAOH, KOH }\end{array}$ \\
& Sodium Day Tanks (2): Ignitable reactive, corrosive, or toxic metal waste: NA NAK, \\
NAOH, KOH & Sodium Reaction Vessel: Toxic metal waste: NA NAK, NAOH, KOH \\
& Caustic Cooling Tank: Na NAK, NAOH, KOH \\
Sodium Processing Facility Caustic Storage Tank: Na NAK, NAOH, KOH \\
Water Holding Tank: Corrosive or toxic metal waste
\end{tabular}


Table 1. (continued).

\begin{tabular}{|c|c|}
\hline Maximum Volume & 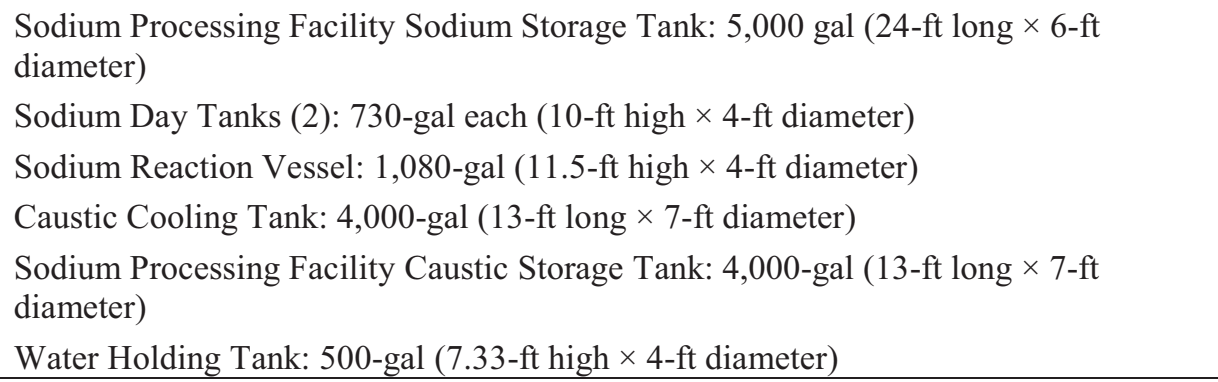 \\
\hline $\begin{array}{l}\text { Tank Construction } \\
\text { Material }\end{array}$ & $\begin{array}{l}\text { Sodium Processing Facility Sodium Storage Tank: Carbon steel (0.25 in.) } \\
\text { Sodium Day Tanks (2): Carbon steel ( } 0.25 \text { in.) } \\
\text { Sodium Reaction Vessel: S-200 nickel ( } 0.25 \text { in.) } \\
\text { Caustic Cooling Tank: S-200 nickel ( } 0.13 \text { in.) } \\
\text { Sodium Processing Facility Caustic Storage Tank: S-300 stainless steel (0.25 in.) } \\
\text { Water Holding Tank: S-304 stainless steel (10 gauge) }\end{array}$ \\
\hline Activities Allowed & Storage, deactivation (ignitable/reactives), melt/drain, and neutralization \\
\hline $\begin{array}{l}\text { Secondary Containment } \\
\text { System Description }\end{array}$ & $\begin{array}{l}\text { Sodium Processing Facility Sodium Storage Tank and Sodium Day Tanks (2): Carbon } \\
\text { steel }(0.19 \text { in. }) \text { over sand floor and concrete walls }- \text { dimensions: } 41 \mathrm{ft} \times 16 \mathrm{ft} \times 1.5 \mathrm{ft}- \\
\text { capacity: } 7,360 \text {-gal } \\
\text { Sodium Reaction Vessel and Caustic Cooling Tank: Type }- \text { Carbon steel-lined } \\
(0.19 \text { in. }) \text { compacted-sand floor pit and formed concrete walls }- \text { dimensions: } 21.5 \mathrm{ft} \times \\
13 \mathrm{ft} \times 14 \mathrm{ft}-\text { capacity: } 2,440 \text {-gal } \\
\text { Sodium Processing Facility Caustic Storage Tank: Type - carbon-steel lined - } \\
\text { dimensions: } 12 \mathrm{ft} \times 17 \mathrm{ft} \times 3 \mathrm{ft}-\text { capacity: } 4,580 \text {-gal } \\
\text { Water Holding Tank: Capacity }- \text { drain into the Caustic Tank Pit. Caustic Tank Pit: } \\
2,440 \text {-gal }- \text { dimensions: } 21.5 \mathrm{ft} \times 13 \mathrm{ft} \times 14 \mathrm{ft}\end{array}$ \\
\hline
\end{tabular}

Table 2 provides a reference to major system drawings and photographs contained in Appendices B and $\mathrm{C}$, respectively.

Table 2. Sodium Processing Facility system descriptions.

\begin{tabular}{|l|l|l|}
\hline \multicolumn{1}{|c|}{ System } & \multicolumn{1}{|c|}{ Drawings } & \multicolumn{1}{c|}{ Photos } \\
\hline $\begin{array}{l}\text { Sodium Process Facility General } \\
\text { Arrangement } \\
\text { Sodium Process Flow Diagram }\end{array}$ & $\begin{array}{l}\text { W7990-0207-ED-01 } \\
\text { E5274-0006-ED-06 }\end{array}$ & P1015404 through -444 \\
\hline Sodium Drum Melting and Draining System & E5274-0047-ED-01 & $\begin{array}{l}\text { P1015389 through -394 and - } \\
402\end{array}$ \\
\hline Drum Fill and Handling Systems & W7990-0229-ED-01 & $\begin{array}{l}\text { P1015298 through -300, -302, } \\
\text { and -307 }\end{array}$ \\
\hline Service and Suspect Water Systems & E5274-0179-ED-07 & P1015405 and -415 \\
\hline Off-Gas Systems & E5274-0054-ED-06 & $\begin{array}{l}\text { P1015318, -319, -321, -330, } \\
-337, \text { and }-343\end{array}$ \\
\hline Steam and Condensate System & E5274-0180-ED-03 & P1015312 and -322 \\
\hline Nitrogen System & E5274-0049-ED-08 & P1015392, -401, -402, and -414 \\
\hline
\end{tabular}

The following subsections provide information regarding the major systems for the Sodium Processing Facility. 


\subsubsection{Sodium Melting and Draining System}

Containerized $\mathrm{Na} / \mathrm{NaK}$ generally arrived at Sodium Processing Facility in 55-gal drums. The sodium melting and draining system was used to do the following:

- Melt NA/NaK (which is solid at room temperature) in its storage container

- Remove $\mathrm{Na} / \mathrm{NaK}$ from its storage container

- Transfer it to the 5,000-gal sodium storage tank.

The same process occurred for the $\mathrm{NaK}$, except $\mathrm{NaK}$ is liquid at room temperature; therefore, "melting" NaK was not necessary. The transfer of containerized liquid $\mathrm{Na} / \mathrm{NaK}$ was by vacuum pump to the 5,000-gal sodium storage tank.

\subsubsection{Sodium Transfer System}

The sodium transfer system was used to transfer the waste $(\mathrm{Na} / \mathrm{NaK})$ from the 5,000-gal sodium storage tank to the 730-gal sodium day tanks. Following completion of the melting and draining operation from the drums to the 5,000-gal sodium storage tank, the 5,000-gal sodium storage tank was pressurized with nitrogen. The pressurization provided the driving force to transfer the $\mathrm{Na} / \mathrm{NaK}$ from the 5,000-gal sodium storage tank to the selected 730 -gal sodium day tank. The transfer rate was approximately 39 gallons per minute.

\subsubsection{Sodium Reaction System}

The sodium reaction system was used to do the following:

- Transfer $\mathrm{Na} / \mathrm{NaK}$ from the 730 -gal sodium day tanks to the 2,440-gal reaction vessel, where it was converted to a hydroxide solution

- Transfer hydroxide to the drum fill station

- Transfer $50 \mathrm{wt} \%$ hydroxide to the 1,000-gal caustic cooling tank and from the caustic cooling tank to the reaction vessel during startup.

When the reaction vessel was in operation, the 730-gal sodium day tank supplying the waste to the reaction vessel was pressurized with nitrogen gas. This provided the driving force for the $\mathrm{Na} / \mathrm{NaK}$ transfer and injection into the reaction vessel.

In the reaction vessel, the $\mathrm{Na} / \mathrm{NaK}$ reacted with water to produce sodium hydroxide/potassium hydroxide and hydrogen $\left(\mathrm{H}_{2}\right)$. Reaction: $\mathrm{Na}+2 \mathrm{H}_{2} \mathrm{O}+$ caustic $=>\mathrm{NaOH}+\mathrm{KOH}+\mathrm{H}_{2}$.

Nitrogen/steam was introduced into the injection nozzles to atomize the $\mathrm{Na} / \mathrm{NaK}$ upon injection into the reaction vessel to ensure the $\mathrm{Na} / \mathrm{NaK}$ would react completely beneath the surface of the hydroxide solution. The nitrogen left the reaction vessel via the caustic off-gas system along with the reaction-produced hydrogen and some water vapor.

The hydroxide in the reaction vessel was recirculated with approximately 1 to 2 gallons per minute of the 8 to 10 gallons per minute recirculated solution continuously diverted to either the drum fill station (during operation) or to the 1,000-gal caustic cooling tank (during shutdown operations).

\subsubsection{Caustic Transfer System}

The caustic transfer system began at the reaction-vessel solution caustic recirculation pump and piping where a portion of the hydroxide being recirculated was diverted to the drum fill station or to the 
1,000-gal caustic cooling tank. The caustic metering pump transferred the $50 \mathrm{wt} \%$ hydroxide solution form the 1,000-gal caustic cooling tank directly to the reaction vessel upon startup, or if backup hydroxide storage was needed. The 4,000-gal caustic storage tank was used (in an emergency only) to transfer hydroxide solution to or from the caustic storage tank to the reaction vessel. The caustic recirculation pump, metering pump, and the caustic cooling tank are located in the sodium process area and the caustic storage tank and caustic transfer pump are housed in MFC-799A, a building on the west side of Sodium Processing Facility.

\subsubsection{Drum Fill and Handling System}

The hydroxide solution was transferred to the drum fill station through a concentric pipe heat exchanger. The heat exchanger is an inner pipe (nickel) for high-temperature hydroxide and an outer pipe (stainless steel) for the coolant (water).

The high-temperature hydroxide (i.e., 360 to $375^{\circ} \mathrm{F}$ ) flowed from the caustic recirculation line to the drum fill station. At the drum fill station, the hydroxide exited into the drums at an approximate temperature of 200 to $225^{\circ} \mathrm{F}$. The reduction of the hydroxide temperature was by the counter-flow of coolant (water). Heat was removed from the cooling medium of the concentric pipe heat exchanger system via a shell and tube water heat exchanger.

The suspect exhaust off-gas system collected vapors from the enclosures (hood) for the drum fill and capping stations. From the hoods, the effluent (consisting mainly of minute quantities of hydroxide vapor and potentially some entrained particulate) was exhausted through a baghouse and HEPA filter to the atmosphere.

The product from the caustic transfer system was placed in drums via the drum fill and handling system, which included the drum filling station, capping station, survey and decontamination station, drum palletizing area, and storage areas.

\subsubsection{Service and Suspect Water Systems}

Two separate water systems - the service and suspect water systems - comprised the Sodium Processing Facility water system. The service water system was a clean potable water system and had the following two main functions in the sodium process area:

- Cooled the off-gas condenser

- Served as a heat sink for the shell and tube (concentric pipe) heat exchanger.

The service water supply delivers water to Sodium Processing Facility at approximately 100 psig through galvanized-steel piping.

The suspect water system was potentially contaminated with radioactive constituents from the processed $\mathrm{Na} / \mathrm{NaK}$. Makeup water was supplied to a 500-gal holding water holding tank from the MFC deionized water system. [NOTE: This tank is shown on facility drawings, but was not observed on facility walk-down]. The suspect water system's main function was to provide water from the 500-gal water holding tank for the following uses:

- Hydrolyze $\mathrm{Na} / \mathrm{NaK}$ in the reaction vessel

- Dewater and cleanse off-gas emissions from the reaction vessel

- Maintain water level in the scrubber. 
Sources of suspect water in the Sodium Processing Facility include the following:

- Condensed water vapor that is removed from the off-gas streams of the reaction vessel

- Water associated with cleanup activities associated with potentially-contaminated areas or surfaces.

The water system was used for cooling the vacuum pump inlets, off-gas condenser, caustic transfer system shell, tube heat exchanger, and for use in the scrubber.

\subsubsection{Off-Gas Systems}

Two separate off-gas systems were used to control effluent release from Sodium Processing Facility treatment operations. The system controlled effluents from the sodium process area and the suspect exhaust system controlled effluents from the sodium carbonate process area as described in the following subsections.

3.1.7.1 Caustic Off-Gas System. The caustic off-gas system was used to contain the gases and water vapor resulting from the conversion of $\mathrm{Na} / \mathrm{NaK}$ to hydroxides in the reaction vessel. It condensed and recovered water vapor for reuse and removed radioactive aerosol prior to the release of filtered gases to the atmosphere. Principle constituents in the caustic off-gas stream, as it exited the reaction vessel, were water vapor, hydrogen, and nitrogen. Hydrogen was a reaction product. Nitrogen was used to atomize the $\mathrm{Na} / \mathrm{NaK}$ in the reaction-vessel injection nozzles and to purge the reaction vessel to maintain low oxygen concentrations. The caustic off-gas system processed this stream and ultimately released hydrogen and nitrogen to the atmosphere and returned the condensed water vapor to the reaction process. Condensate was returned to the 500-gal water holding tank through a series of drain lines.

3.1.7.2 Suspect Exhaust System. The purpose of the suspect exhaust system was to control effluents that may be generated during the drum filling and capping processes. The off-gas consisted primarily of hydroxide vapor and particulate. The off-gas stream from the drum fill and capping stations exited the hoods surrounding the drum into the suspect exhaust system. This effluent was processed through a HEPA filtration system prior to release to the atmosphere. The effluent gas from the baghouse then passed through a HEPA filter that removed remaining particulate prior to discharge to the atmosphere.

3.1.7.3 Vent Systems. There are two independent vent systems associated with the Sodium Process Area (MFC-799) and 4,000-gal caustic storage tank (MFC-799A). All vent system piping is made of carbon steel. In the sodium process area, the vent systems collected gaseous effluents from all of the following tanks:

- 5,000-gal sodium storage tank

- 730-gal sodium day tanks

- 1,000-gal caustic cooling tank

- 4,000-gal caustic storage tank

- 500-gal water holding tank.

Effluent from the 5,000-gal sodium storage tank included vacuum pump exhaust, normal operational venting, or effluent from the poppet check valve. Effluent from the 730-gal sodium day tanks and 1,000-gal caustic cooling tank included normal operational venting or over-pressurization release from their respective poppet check valves. Effluent from the 500-gal water holding tank included normal operational venting through its own HEPA filter on top of the tank. These effluent streams vented to the caustic off-gas system upstream of the HEPA filters. 
In the sodium carbonate process area addition, the sources of effluents were the drum fill and capping station hoods. All vent piping in this area is made of stainless steel.

3.1.7.4 Steam and Condensate System. Steam was used for the following:

- Atomization of the $\mathrm{Na} / \mathrm{NaK}$

- Clearing of the injection nozzles in the reaction vessel in the sodium process area.

The 175-psig steam from the site steam supply was reduced in pressure to 30 to 50 psig for the injection process in the reaction. The steam system piping is made of carbon steel. Solenoid, ball, globe, and gate valves were used in the system. Relief valves provided overpressure protection.

3.1.7.5 Nitrogen System. Nitrogen gas was used in the sodium melting and draining room and sodium process area as follows:

1. Sodium Melting and Draining Room - Nitrogen was applied to the drums of $\mathrm{Na} / \mathrm{NaK}$ (while being heated) and flexible drain lines (when not in use). It was supplied at 3 to 5 in. $\mathrm{H}_{2} \mathrm{O}$.

2. Sodium Process Area - Nitrogen was used in the sodium process area to transfer sodium from the following:
a. 5,000-gal sodium storage tank to the 730-gal sodium day tanks (nitrogen was supplied at 15 psig)
b. $\quad 730$-gal sodium day tanks to the injection nozzles (nitrogen was supplied at 10 to $30 \mathrm{psig}$ ).

3.1.7.6 Support Systems. The support systems for operation of the Sodium Processing Facility are described in the following subsections.

\section{following: \\ 3.1.7.6.1 Compressed Air System-The compressed air system was used to do the}

- Operate the barrel tilting mechanism for the melting-draining operation

- Operate the pneumatically actuated valves in the Na, caustic, and vacuum piping

- Operate the pneumatic tilting device to move drums of hydroxide to the drum palletizing area.

3.1.7.6.2 Heater System-The following five types of heaters were used throughout the process: drum strap-on heaters, disc heaters, strip heaters, mineral insulated wire, and heating tape.

3.1.7.6.3 Fire Suppression System-A fixed fire suppression system was provided in the sodium melting and draining room. Two ANSUL MET-L-X, Model 101-30, dry-powder fire extinguishers were provided to discharge through four modified ANSUL F-1 nozzles directly into each barrel container assembly. A single actuator was provided for each of these pairs of extinguishers. A fire hazard analysis of other Sodium Processing Facility areas determined that additional fire suppression systems were not required.

\subsubsection{Major Spills or Leaks}

There has been only one incident of a spill or leak that qualified for the filing of an Occurrence Report. It was a Na leak associated with a small crack at the root of the reducer connecting the 3/4-in. stainless steel piping to the 3/8-in. nickel tubing for the sodium injection nozzle on the Sodium Reaction Vessel in MFC-799. Evaluation of the failed reducer by a materials characterization engineer confirmed the failure (crack) was fatigue induced by excessive movement in the piping runs from the sodium day tanks to the sodium reaction vessel. 
Approximately $4 \mathrm{oz}$ of sodium were leaked; the total amount was contained in the reaction vessel secondary containment. The sodium did not react and burn when exposed to air. The smoke appeared to come from the outside material of the pipe lagging. No hazardous material was released to the environment nor was the health and safety of personnel ever compromised.

Details of this occurrence may be found in Occurrence Report Number: NE-CH-AA-ANLW-EBR1999-0001, "Sodium Leak in the Sodium Process Facility."

There also was a small leak associated with the failure of the caustic pump. No Occurrence Report was filed as this failure happened during testing with clean caustic. The record of the leak is in the $\log$ book that will be turned over to CH2M-WG Idaho, LLC with the building.

\subsection{Caustic Storage Area Process Description}

The purpose of the Caustic Storage Area was to house the caustic storage tank, pump, and associated plumbing to transfer the caustic from the storage tank to MFC-799 for use in the sodium processing operation. The pad-mounted, exterior, caustic storage tank (A23-T-203) was intended to provide additional storage capacity, but it has never had any caustic or any other hazardous or radioactive material placed in it.

\subsubsection{Major Spills or Leaks}

There have been no spills or leaks associated with the Caustic Storage Area.

\subsection{Nuclear Calibration Laboratory Basic Process Description}

The laboratory was used to calibrate radiation detection/measurement instruments. The calibration equipment consists of a JL Sheperd Model 81-12 Beam Calibrator and Model 155 Attenuator System and a Cs-137 Source. This Cs-137 source was validated to be $200 \mathrm{Ci}$ on August 19, 1975. Based on a 30.3 year half-life, the $\mathrm{Cs}-137$ source should be approximately $94 \mathrm{Ci}$ in strength.

\subsubsection{Major Spills or Leaks}

There have been no spills or leaks associated with the Nuclear Calibration Laboratory.

\section{EXISTING PHYSICAL CONDITIONS}

\subsection{Structures}

\subsubsection{Condition Assessments}

All facilities appear to be structurally sound and secure. There is no evidence of any damage or deterioration other than normal wear and tear incident to age and the normal effects of weather.

\subsubsection{Engineered Protective Barriers and Systems}

All installed equipment items (e.g., tanks and filters) used to process hazardous materials remain in place and appear to have maintained their integrity. There is no evidence of leakage and all openings are properly sealed or closed off and connections are sound. The pits appear clean with no evidence of cracking or deterioration that could lead to migration of contamination. 


\subsection{Required Follow-up Activities}

The MFC-799 and MFC-799A facilities are still covered under the MFC Hazardous Waste Management Act RCRA Storage and Treatment Permit, No. ID4890008952, dated August 16, 2004, and modified on October 2, 2008. Therefore, inspections related to these two facilities as specified in Appendix D of that permit will need to be complied with until such time as the facilities meet the RCRA Closure criteria. MFC-770C is not part of the RCRA permit.

The primary power line that supplies power to the Radioactive Waste Storage Facility will need to be rerouted prior to transition of ownership for the Sodium Processing Facility.

\section{EXISTING HAZARDOUS RADIOLOGICAL AND CHEMICAL CONTAMINATION}

MFC-799 and -799A both contain radiological and nonradiological hazardous materials and MFC-770C contains a sealed Cs-137 source. The hazardous materials in MFC-799 and MFC-799A are processing "heels" that are contained within enclosed tanks. The MFC-770C source is properly contained, and MFC-770C is a secure, controlled-entry building. The radiological hazards associated with MFC-799 and MFC-799A are less than Hazard Category-3 quantities per DOE-STD-1027-92, "Hazard Categorization and Accident Analysis Techniques for Compliance With DOE Order 5480.23, Nuclear Safety Analysis Reports," whereas the quantity of source material in MFC-770C designates that facility as Hazard Category-3. Inventories are provided in Section 7 of this report.

\section{$5.1 \quad$ MFC-799}

While radiological surveys indicate no external contamination of concern, past operational surveys have indicated significant counts (up to $40,000 \mathrm{cpm}$ ) on internal components, particularly the caustic recirculation pump at the bottom of the sodium reactor. The MFC-799 sodium tanks were drained as low as practical and have only "heels" remaining in the tanks. There is an estimated residual of approximately 200 to 240 gal of $50 \%$ by weight sodium hydroxide solution present in these tanks that will be transferred to EM with the facility.

\subsection{MFC-799A}

The 4,000-gal caustic storage tank within MFC-799A is estimated to contain a residual "heel" of approximately 50 gal of $50 \%$ by weight solution of sodium hydroxide that will be transferred to EM with the facility.

\subsection{MFC-770C}

MFC-770C has no contamination.

\section{SPECIAL NUCLEAR AND FISSIONABLE MATERIALS INVENTORY}

The only special nuclear material associated with these facilities is the Cs-137 source material in the Nuclear Calibration Laboratory (MFC-770C). Currently, the following four disposition options are available:

3. Relocate source "as is" to another INL laboratory

4. Ship source back to supplier for refurbishment and return to service within the DOE complex

5. Ship source back to supplier for disposition 
6. Ship source to the Off-site Source Recovery Project at the Los Alamos National Laboratory, New Mexico, for disposition.

NE will make the appropriate determination of which option is most cost effective and complete this action prior to facility transfer.

\section{HAZARDOUS MATERIALS, WASTE, AND CHEMICAL INVENTORIES}

Table 3 summarizes the hazardous materials, waste, and chemical inventories for the facilities being transferred. Note that some materials have been exempted from further consideration due to the relatively small quantities remaining.

Table 3. Hazardous material, waste, and chemical inventory.

\begin{tabular}{|c|c|c|c|c|c|}
\hline Location & Material & $\begin{array}{c}\text { Maximum } \\
\text { Quantity }\end{array}$ & $\begin{array}{l}\text { Threshold } \\
\text { Quantity }\end{array}$ & $\begin{array}{c}\text { Threshold } \\
\text { Quantity Reference }\end{array}$ & $\begin{array}{c}\text { Basis for Exemption } \\
\text { from Further } \\
\text { Consideration } \\
\end{array}$ \\
\hline $\begin{array}{l}\text { MFC-799 } \\
\text { and } \\
\text { MFC-799A }\end{array}$ & Radiological & $\begin{array}{l}\text { Less than } \\
\text { Hazard } \\
\text { Category-3 }\end{array}$ & NA & DOE-STD-1027.92 & $\begin{array}{l}\text { MFC-799 and } \\
\text { MFC-799A are less than } \\
\text { Hazard Category-3 } \\
\text { facilities }\end{array}$ \\
\hline MFC-770C & Radiological & $100 \mathrm{Ci}$ & $\begin{array}{l}60 \text { Ci for } \\
\text { Hazard } \\
\text { Category-3 }\end{array}$ & DOE-STD-1027.92 & Not exempted \\
\hline $\begin{array}{l}\text { MFC-799 } \\
\text { and } \\
\text { MFC-799A }\end{array}$ & Sodium & NA & NA & NA & $\begin{array}{l}\text { The MFC- } 799 \text { sodium } \\
\text { tanks have been drained } \\
\text { to an "as low as } \\
\text { practical" level; this is } \\
\text { judged to be reasonable } \\
\text { to exempt the sodium } \\
\text { from further evaluation }\end{array}$ \\
\hline MFC-799 & $\begin{array}{l}\text { Sodium } \\
\text { hydroxide }\end{array}$ & $1,522 \mathrm{lb}$ & $\begin{array}{l}5,000 \mathrm{lb} \\
(5 \times 1,000)\end{array}$ & $\begin{array}{l}\text { Less than five times the } \\
\text { reportable quantity of the } \\
\text { screening threshold in } \\
40 \text { CFR } 302.4 \text {, } \\
\text { Table } 302.4 \text {; however, } \\
\text { material has a National } \\
\text { Fire Protection } \\
\text { Association Health Hazard } \\
\text { Rating of } 3 \text { with a quantity } \\
\text { greater than laboratory } \\
\text { quantity (approximately } \\
5 \text { gal or } 40 \text { lb) }\end{array}$ & NA \\
\hline
\end{tabular}


Table 3. (continued).

\begin{tabular}{|c|l|l|l|l|l|}
\hline Location & Material & $\begin{array}{c}\text { Maximum } \\
\text { Quantity }\end{array}$ & $\begin{array}{c}\text { Threshold } \\
\text { Quantity }\end{array}$ & $\begin{array}{c}\text { Threshold } \\
\text { Quantity Reference }\end{array}$ & $\begin{array}{c}\text { Basis for Exemption } \\
\text { from Further } \\
\text { Consideration }\end{array}$ \\
\hline MFC-799A & $\begin{array}{l}\text { Sodium } \\
\text { hydroxide }\end{array}$ & $317 \mathrm{lb}$ & $\begin{array}{l}5,000 \mathrm{lb} \\
(5 \times 1,000)\end{array}$ & $\begin{array}{l}\text { Less than five times the } \\
\text { reportable quantity of the } \\
\text { screening threshold in } \\
\text { 40 CFR 302.4, } \\
\text { Table 302.4; however, } \\
\text { material has a National } \\
\text { Fire Protection } \\
\text { Association Health Hazard } \\
\text { Rating of 3 with a quantity } \\
\text { greater than laboratory } \\
\text { quantity (approximately } \\
\text { gal or 40 lb) }\end{array}$ \\
\end{tabular}

\section{FIXED OCCUPATIONAL HAZARDS}

The only occupational hazards noted on the walk-down were two uncaged ladders and miscellaneous tripping hazards due to clutter in some areas. The first ladder is on the north exterior wall of MFC-799 and the second is located inside MFC-799 on the west side of the mezzanine. The tripping hazards will be eliminated as excess equipment is removed from the facility prior to transfer.

\section{TRANSFER CONSIDERATIONS}

\subsection{Documents}

\subsubsection{Permits, Licenses, and Agreements}

MFC-799 and MFC-799A are included in the following permits:

- $\quad$ MFC Hazardous Waste Management Area RCRA Storage and Treatment Permit, No. ID4890008952, dated August 16, 2004, and modified on October 2, 2008

- $\quad$ Air Quality Tier I Operating Permit, No T1-030520, Facility ID Nos. 023-0001, 011-00022.

\subsubsection{Outstanding Commitments}

There are no outstanding commitments related to MFC-799, MFC-799A, and MFC-770C.

\subsubsection{Excess Equipment and Material}

Excess equipment associated with MFC-799 and 799A includes the following:

- Daewoo BC30S electric forklift and charger

- Spacemaster II 5-ton single beam overhead electric hoist

- P\&H Beta HEVI-LIFT 500-lb overhead gantry crane

- $\quad$ P\&H Spectrum 1,000-lb pedestal crane.

Excess equipment associated with MFC-770C includes the following:

- JL Sheperd Model 81-12 beam calibrator (Serial No. 540) 
- JL Sheperd Model 155 attenuator system (Serial No. 783) (with Cs-137 source).

\subsection{Stabilization and Other Required Actions Required for Transfer}

The criteria/end points that must be met prior to facility transfer, the current status of each, and the actions that remain to be completed are listed as follows. Estimates for the time required to complete the action and associated cost are shown in parentheses following the activity description.

1. Facility Structure/Personnel Safety - Structural integrity is such that (1) inspection personnel are safe, and (2) engineered protective barriers and containment systems (for example, but not limited to, safety class systems) are sufficient to prevent the release of radiological or hazardous chemical substances.

Status: Facilities have been walked down and determined to be structurally sound. Hazardous materials are safely and effectively contained and present minimal risk as long as enclosures (tanks in the case of MFC-799 and 799A and sealed source in the case of MFC-770C) are not breached.

Actions to be Completed: None.

2. Process Systems and Equipment - Process systems and equipment are systematically shut down, isolated, sealed off, or removed (if there is a compelling reason to do so) to establish a stable and known condition.

Status: MFC-799 and 799A process systems and equipment were systematically shut down when these facilities were placed in standby in March 2001. The source contained in MFC-770C is secure. The systems and equipment for all three facilities are in stable and known conditions.

Actions to be Completed: None.

3. Service and Utility Systems and Equipment - Only systems required to support disposition and surveillance and maintenance and maintain the stable condition (such as lighting, exhaust ventilation, and sump pumps) are operational. Equipment that has been judged to be valuable for future decommissioning is left available for future use. Other utility systems are isolated or sealed off for safety of future personnel or removed (if there is a compelling reason to do so).

Status: All three facilities are in stable condition and necessary support systems remain operational.

Actions to be Completed:

- Modification of electrical service for the Radioactive Storage Waste Facility(MFC-771) (14 days, $\$ 52,500)$

- Electrical engineering and design (10 days, \$12,100)

- Install new underground power duct bank for power to MFC-771 (4 days, $\$ 28,000$ )

- Install new power panel and disconnects (1 day, \$5,200)

- Outage - disconnect old power/reconnect new power systems and re-energize new power supply system (1 day, \$4,500)

- Final burial of manholes and final cleanup of site areas (1 day, \$1,500)

- As built drawings/final report (2 days, \$1,200)

- Disposition of equipment and property (20 days, \$66,100)

- Delisting of excess property - disposition of equipment to other programs (10 days, $\$ 12,000)$

- Removal of applicable excess equipment (7 days, \$27,000)

- Removal of stored materials and equipment - interior of MFC-799, 799A and 770C (5 days, $\$ 19,300)$ 
- Removal of stored materials and equipment - exterior of MFC-799 and 799A (2 days, $\$ 7,800)$.

4. Radiation Protection - Barriers and so forth are established in accordance with standard procedure per the site/DOE radiological control manual. Radioactive contamination remaining in the facility is contained in limited areas or has been stabilized against release.

Status: Radioactive contamination in MFC-799 and 799A is internal to tanks and systems, is properly placarded, and is considered stabilized against release. There is no radioactive contamination at MFC-770C.

Actions to be Completed: None.

5. Radioactive Materials - Radioactive materials are removed.

Status: There are no radioactive materials in MFC-799 or 799A. MFC 770C contains a sealed Cs-137 source.

Actions to be Completed: Removal and disposition of the Cs-137 source (assuming the source will be excessed) (14 to 20 days, $\$ 82,000)$.

6. Hazardous Materials and Waste - Hazardous materials and chemicals are removed in accordance with environmental regulations. The only liquids remaining are minor quantities that cannot be readily removed with installed equipment. Where feasible, RCRA closure has been achieved for listed materials. Hazardous materials remaining in the facility are contained in limited areas or have been stabilized against release. Documentation of the amount and location of remaining hazardous material is complete.

Status: The hazardous materials and chemicals remaining are residuals (i.e., heels) within the processing and storage vessels in MFC-799 and 799A. These are minor quantities that cannot be readily removed, are in a stabilized condition, and will be transferred to EM with the facilities. Estimated quantities are documented and are presented in this report. RCRA closure activities will be performed by EM post-transfer.

\section{Actions to be Completed:}

- $\quad$ Limited characterization plan development (4 days, \$6,000)

- Verification of caustic and sodium levels in tanks/vessels (4 days, \$36,000)

- $\quad$ Transfer MFC-799 and 799A out of the PER 116 MFC RCRA Permit (45 days, \$8,400).

7. Housekeeping and Miscellaneous Materials - Classified and valuable materials are removed. Remove all classified documents, materials, and tools and downgrade security requirements.

Status: There are no classified materials in any of these facilities. Other housekeeping activities will be completed as part of the disposition of equipment and property activities associated with Item 3 in the list above.

Actions to be Completed: Prepare end state condition report (5 days, \$12,700).

\subsection{Cost Estimates}

Summary costs estimates are provided in Table 4 . The detailed estimates from which they are derived may be found in Appendix E.

Table 4. Summary cost estimates.

\begin{tabular}{|l|l|r|}
\hline Category & Itemized Expense & Category Total \\
\hline Surveillance and maintenance & & $\$ 20,800 / \mathrm{mo}$ \\
\hline
\end{tabular}




\begin{tabular}{|l|r|c|}
\hline MFC-799 and 799A & $\$ 18,500 / \mathrm{mo}$ & \\
\hline MFC-770C & $\$ 2,300 / \mathrm{mo}$ & \\
\hline Stabilization activities & & $\$ 198,300$ \\
\hline Calibration source disposition & $\$ 82,000$ & \\
\hline Excess equipment/property disposition & $\$ 66,100$ & \\
\hline Reroute of electrical service for the Radioactive Waste Storage Facility & $\$ 52,500$ & \\
\hline Characterization and Transfer MFC-799/799A RCRA Permit & & $\$ 50,400$ \\
\hline End state condition report preparation & & $\$ 12,700$ \\
\hline
\end{tabular}

\section{SUMMARY, CONCLUSIONS, AND RECOMMENDATIONS}

MFC-799, 799A, and 770C are excess to future NE mission requirements. These facilities are in good overall physical condition, and associated hazardous or potentially hazardous conditions are well defined and well understood. Transfer of these facilities from NE to EM and an associated schedule for doing so have been agreed upon by the two offices. The prerequisites for this transfer are the removal of nonexcess materials and chemical inventory, deinventory of the calibration source in MFC-770C, and the rerouting or isolation of utility and service systems.

Based on the available information/documentation reviewed and overall conditions observed during the facilities walk-down, it is concluded that these facilities may be disposed of at minimal risk to human health and safety or the environment.

Therefore, the following is recommended:

1. NE proceed with stabilization activities that will ensure the identified pre-transfer end states are met

2. Upon completion of these pre-transfer requirements, NE and EM perform a joint pre-transfer review, which will include a joint facility walk-down

3. NE and EM execute a final transfer memo documenting date of transfer and any other information pertinent to the transfer of management responsibility.

\section{REFERENCES}

40 CFR 270, "EPA Administered Permit Programs: the Hazardous Waste Permit Program," Code of Federal Regulations, Office of the Federal Register, 2000.

IDAPA 58.01.05, July 2000, "Rules and Standards for Hazardous Waste," Idaho Administrative Code, Idaho Administrative Procedures Act, Idaho Department of Environmental Quality.

MFC Hazardous Waste Management Act RCRA Storage and Treatment Permit, No. ID4890008952, dated August 16, 2004, and modified on October 2, 2008.

Air Quality Tier I Operating Permit, No T1-030520, Facility ID Nos. 023-0001, 011-00022 (Section 3.4).

EHA-70, Appendix R, “Emergency Management Hazards Assessment for MFC-799, Sodium Process Facility, and MFC-799A, Caustic Storage Tank Building,” Rev 0, Effective Date July 05, 2006. 
DOE-STD-1027-92, "Hazard Categorization and Accident Analysis Techniques for Compliance with DOE Order 5480.23, Nuclear Safety Analysis Reports," U.S. Department of Energy, December 1992. 
Appendix A

Facilities Walk-Down Checklist 


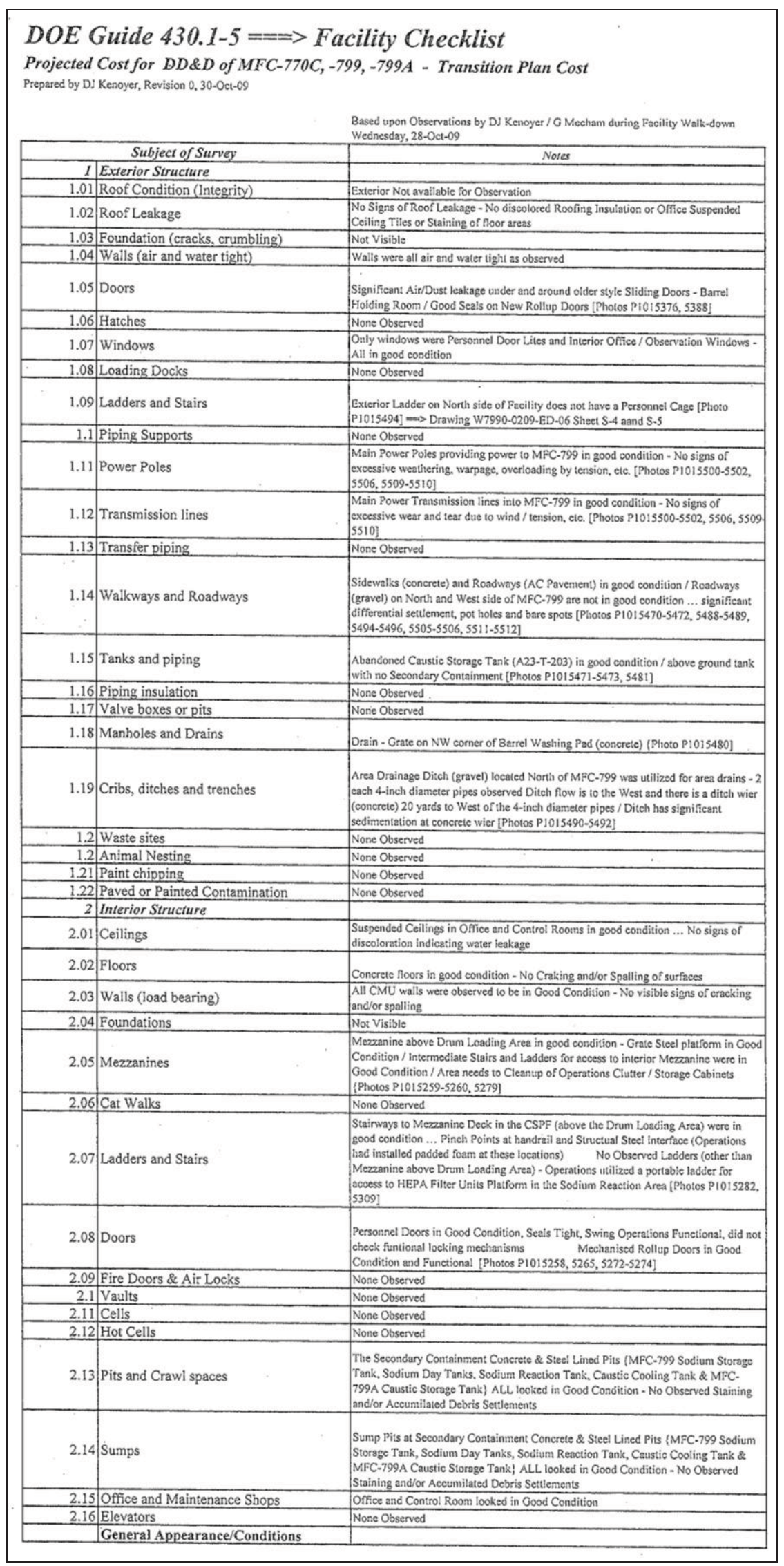




\begin{tabular}{|c|c|c|}
\hline 2.17 & Housekeeping & $\begin{array}{l}\text { Observed Areas - Good Housckeeping - All Areas keep neat and orderly / Some } \\
\text { Limited Cleanup Required } \Rightarrow \text { NOTE: Need to Relocate ALL Storage ltems from this } \\
\text { Facility to Other Storage Locations in Preparation for Transition / Transfer ... } \\
\text { Equipment Laydown Area [Pholos P1015258-5267,5324-5325] ... Barrei Holding } \\
\text { Area [Plotos P1015376-77, 5381-5385, 5445-5446] ... Metting Draining Room } \\
\text { [Pliotos P101597-5400, 5403] .. Sodium Reaction Room [Pholo P1015406] }\end{array}$ \\
\hline 2.18 & Maintenance & Oosserved Areas - Good S\&M, being Maintained \\
\hline 2.19 & Lighting & $\begin{array}{l}\text { Observed Areas - Good Lighting / Ail Lighting Fixtures working properiy - No } \\
\text { Observed burned out ballasts, elc. }\end{array}$ \\
\hline 2.2 & Signage & Observed Sigrage Scemed up to date and aderguate \\
\hline 2.21 & Access Control & Access to Facility is Limited by Locked and Controlled Access \\
\hline \multirow[t]{2}{*}{3} & Environmental Compliance & \\
\hline & Liquid Effluents & \\
\hline 3.01 & Liquid Discharge Points & See 1.19 \\
\hline 3.02 & Cribs, Ditches, Ponds & See 1.19 \\
\hline 3.03 & Sampling and monitoring & None Observed \\
\hline 3.04 & Abandoned systems & None Observed \\
\hline 3.05 & Marking and Mapping & Not Know a This Time \\
\hline 3.06 & Characterization info & Not Know a This Time \\
\hline 3.07 & Storm water Management & Not Know a This Time \\
\hline \multirow{2}{*}{3.08} & Records Retention & Not Know a This Time \\
\hline & Gaseous Effluents & \\
\hline 3.09 & Discharge Points (stacks) & $\begin{array}{l}\text { Stack Not Observed - Known to have } 2 \text { Stacks on MFC-799 } \Rightarrow \text { 1) Sodium Reactor } \\
\text { Off-Gas and 2) Carbonate Drum Loading Off-Gas Both these OfroGas systems } \\
\text { inciuded Pre-Fitilers and HEPA Filters proor to disclarge into Stack }\end{array}$ \\
\hline 3.1 & Fugitive Emission sources & Not Know a This Time \\
\hline 3.11 & Sampling and monitoring & $\begin{array}{l}\text { Low Oxygen Monitoring in the Sodium Reaction Room with Low Oxygen Alarm } \\
\text { f:1307 [Photo PI0:5432] }\end{array}$ \\
\hline 3.12 & Abandoned systems & $\begin{array}{l}\text { The } \mathrm{CO}_{2} \text { Storage Tank Pad (50 ton tank capacity) located East of the MFC-799 facility } \\
\text { shown on Drawings W7990-0207-ED-01, w7990-0209-ED-06 Sheet } 3 \text { of } 32 \text {, shect } 5 \\
\text { of } 32 \text {, sheet } 7 \text { of } 32 \text {... is still in place however the } \mathrm{CO}_{2} \text { Storage Tank itself has been } \\
\text { removed previously. This } \mathrm{CO}_{2} \text { Storage Tank provided the } \mathrm{CO}_{2} \text { for the Carbonate } \\
\text { Sodium Process [Photo } \mathrm{P} 1015501 \text {... } \mathrm{CO}_{2} \text { Storage Pad shows a wrapped electrical } \\
\text { manlifit stored in tank location] }\end{array}$ \\
\hline 3.13 & Records Retention & Not Know a This Time \\
\hline 3.14 & Characterization info & Not Know a This Time \\
\hline 3.15 & Filter calibration & Not Know a This Time \\
\hline \multirow{2}{*}{3.16} & Filter loading info & Not Know a This Time \\
\hline & Chemical Management & \\
\hline 3.17 & Spills and Releases & $\begin{array}{l}\text { Two Know Spilis / Releases } \Rightarrow \text { 1) Leak in Magnetic Seals of Caustic Recircuiation } \\
\text { Pump in Sodiumm Reactor Subsystem and 2) Leak in Sodium Injector on Sodium } \\
\text { Renctor Subsystem }\end{array}$ \\
\hline 3.18 & Chemical Storage & None Observed \\
\hline 3.19 & Underground Tanks & None Observed \\
\hline \multirow{2}{*}{3.2} & Records Retention & Not Know a This Time \\
\hline & Regulatory & \\
\hline 3.21 & Permitted Area boundary & MFC-799/ MFC-799A - All Physical Boundaries in Place \\
\hline 3.22 & TSCA -PCB Labeis & None Observed \\
\hline 3.23 & Hazard Labels & Caustic and Sodium Hazards L.abeis throughout the MFC-799, MFC-799A \\
\hline 3.24 & Calibration records/stickers & Observed Calibration Stickers - Facility in Operational Layup Status \\
\hline 4 & Process Systems & \\
\hline 4.01 & Process Contro! Room & $\begin{array}{l}\text { Oeneral Observation - Good Condition / Operations Manuals in Place / Drawings in } \\
\text { Place / File Cabinets Locked / Storage Cabinets containing Electronics Spare Pars / } \\
\text { Old Components, etc. }\end{array}$ \\
\hline 4.02 & Exhaust Systems & $\begin{array}{l}\text { See 3.09/ Drawing ES274-0013-ED-19 } 4 \text { Sheets shows the various Exhaust Details } \\
\text { ES274-0054-ED-?? E-402 Sht 1(C-8)/ E5274-0180-ED-?? R-605 Sht 1(D-8)/ }\end{array}$ \\
\hline 4.03 & Fans & Did NOT Check These \\
\hline 4.04 & Motors & Did NOT Check These \\
\hline 4.05 & Stacks & Sec 3.09 \\
\hline 4.06 & Ductwork & $\begin{array}{l}\text { Bullding HVAC Duet work in Good Condition - Duet Insulation is in place and in } \\
\text { Good Condition }\end{array}$ \\
\hline 4.07 & HEPA Filters & $\begin{array}{l}\text { See } 3.09 \text { - The SPF Operations Manual has a Skematic of the latest physical } \\
\text { configuration of the } 2 \text { eachl Pre-Filters and } 2 \text { each HEPA Filters for the Sodium Renctor } \\
\text { Off-Gas subsystem prior to discharge into the Stack fthe existing drawings found so far } \\
\text { do NOT reflect correct configuration\}) [Photos P1015440-544! - Pre-Filters / Main } \\
\text { HEPA Filters on Platform] }\end{array}$ \\
\hline 4.08 & Off Gas Scrubber & None Observed \\
\hline 4.09 & Stack Monitoring & None Observed \\
\hline 4.1 & Glove Boxes & $\begin{array}{l}\text { Glove Box stored on floor of Equipment Storage Area of CSPF - To be Relocationed } \\
\text { Prior to Turnover / Other Gloveboxes are part of Drum Filling Room [Photos P1015292. } \\
5296,5300-5303]\end{array}$ \\
\hline 4.11 & Lab Hoods & None Observed \\
\hline 4.12 & Fume Hoods & None Observed \\
\hline 4.13 & Vacuum Pumps & $\begin{array}{l}\text { Vacuum Pump (AII-P-401) Appeared in Good Condition [Photo P101xxxx dod Not } \\
\text { Take Pieture] }\end{array}$ \\
\hline 4.14 & Vessels or tanks & $\begin{array}{l}\text { Main Tanks and Vessels shown on Drawing ES274-0006-ED-06 SPF Process Flow } \\
\text { Dingram - ALL in Good Condition [Photos P1015405, 5410, 5413, 5417-5420, 5423- } \\
5424,5438 \text { ] }\end{array}$ \\
\hline 4.15 & Pumps & $\begin{array}{l}\text { Main Pumps shown on Drawing E5274-0006-ED-06 SPF Process Fiow Diagram - ALL } \\
\text { in Good Condition }\end{array}$ \\
\hline 4.16 & Motors & $\begin{array}{l}\text { Motor Control stiown on Drawing E5274-0169-ED-04 Normal Power Singie Line } \\
\text { Diagram } \Rightarrow \text { Specifically MCC.AN1 / MCC.AN2 - All in Good Condition NOTE: } \\
\text { RSIYF BIdg } 771 \text { Powered from MCCCANI 3B 100.4F 50AT labeled os 3B ANOII7 }\end{array}$ \\
\hline 4.17 & Piping & Caustic Piping has High Nickei content/ Sodium Piping \\
\hline 4.18 & Level Detection & $\begin{array}{l}\text { Level Detection Instrumentation is shown on Drawing ES274-0013-ED-19 Sheets } 1 \\
\text { thrut } 4 \Rightarrow \text { High / Low Level Indicalors on Tanks and Vessels - Did Not Check these in } \\
\text { Ficid }\end{array}$ \\
\hline
\end{tabular}




\begin{tabular}{|c|c|c|}
\hline 4.19 & Inert Gas Systems & 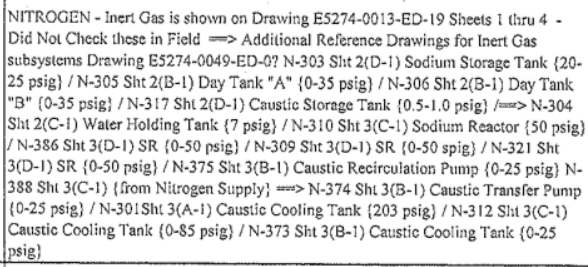 \\
\hline 4.2 & Heat Detection Systems & a \\
\hline \multirow[t]{2}{*}{4.21} & Compressed Air Systems & 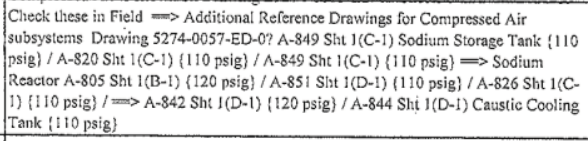 \\
\hline & & $\begin{array}{l}\text { Main Air Compressor supporting the (AFFF) Aqueous Film Forming Foam Alcohol } \\
\text { Type Concentrate Fire Supression subsystem is iocated in the MFC-770B Building } \\
\text { located just South of the MFC-770C / - } 779 \text { facilitilies } m \Rightarrow \text { Drawing W7990-0209-ED-06 } \\
\text { stieet } 32 \text { of } 32 / \text { Photos P1015459 thru P1015466 }\end{array}$ \\
\hline 4.22 & Containment Systems & $\begin{array}{l}\text { The Drum Filling Room served as a Secondary Containment for the Sodium / } \\
\text { Carbonate Drum Filling Operations } \Rightarrow \text { This included Shielding Walls (Concrete 8- } \\
\text { inch to } 12 \text { inch thickness) / Gloveports / Liquid Filled Lead Glass Viewing Window, } \\
\text { etc. [Pholos P1015291-5307] }\end{array}$ \\
\hline 4.23 & Conveyer Systems & $\begin{array}{l}\text { Barel Trasnfer Trolley Subsystem Associaled with the Drum Filling Room Appeared } \\
\text { in Good Condition [Photos P1015268, 5291, 5298] }\end{array}$ \\
\hline 4.24 & Waste Handling Systems & None Observed \\
\hline 4.25 & Waste Assay Systems & None Observed \\
\hline 4.26 & Reactor & $\begin{array}{l}\begin{array}{l}\text { None Observed \{This being a Nuclear Reactor\} The Sodium Reaction Vessel / Tank } \\
\text { was observered to be in Good Condition }\end{array} \\
\end{array}$ \\
\hline 4.27 & Storage Pool or basins & None Observed \\
\hline 4.28 & Manipulators & None Observed \\
\hline 4.29 & Water Filtration & Not Know a This Time \\
\hline 4.3 & Water Treatment & Not Know a This Time \\
\hline 4.31 & Assay Requirements & Not Know a This Time \\
\hline 5 & Infrastructure \& Support Systems & \\
\hline 5.01 & Electrical Distribution & $\begin{array}{l}\text { Set } 1.11 \text { \& } 1.12 \text { / Main Power Transmission lines into MFC-799 in good condition - } \\
\text { [Plioto P1015509] Power Pole PPI } 10 \text { Fed from PPI11 CKTH1 } 480 \text { V (underground } \\
\text { High Voitage) }\end{array}$ \\
\hline 5.02 & Normal Power & $\begin{array}{l}\text { Normal Power shiown on Drawing E5274-0169-ED-04 [Ploto P1015349-5351] } \Rightarrow \\
\text { MCC-ANI }\end{array}$ \\
\hline 5.03 & UPS & None Observed \\
\hline 5.04 & Emergency Generators & $\begin{array}{l}\text { Emergency Power Diesel Generator shown on Drawing E5274-01 82-ED-00 SPF Bldg. } \\
799 \text { Stand-By Power Conduit \& E Euipment } \Rightarrow \text { NOTE: emergency Diesel Generator } \\
\text { Previously Removed [Photos P1015511-5512] }\end{array}$ \\
\hline 5.05 & Steam Turbines & None Observed \\
\hline 5.06 & Switchgear & Seet 5.02 \\
\hline 5.07 & Breaker Panels & See 5.02 \\
\hline 5.08 & General Wiring & General Observation - ALL Wiring in Good Condition \\
\hline 5.09 & Emergency Lighting & Emergency Lighting in Place - Exit Signs Above Doorways, etc. [Photo P1015278] \\
\hline 5.10 & Security Power & None Observed \\
\hline 5.11 & Steam and Water Systems & Still Active and Observered to be Active and in Good Condition [Photo P1015444] \\
\hline 5.12 & Potable Supply & Did Not Observe \\
\hline 5.13 & Process Supply & $\begin{array}{l}\begin{array}{l}\text { Process Water Still under Pressure in Sodium Reactor Area \{Observed Pressure of } 70 \\
\text { psig) }\end{array} \\
\end{array}$ \\
\hline 5.14 & Distiller & None Observed \\
\hline 5.15 & Floor and Sanitary Drains & None Observed \\
\hline 5.16 & Process Drains & $\begin{array}{l}\text { Process Drain at corner of Secondary Containment Pit / Sodium Reactor Vessel Pit and } \\
\text { Soditum Storage \& Sodium Day Tanks "A" \& "B" Pit [Photos P101xxxx Did NOT Take } \\
\text { Photos of Sumps / Drains] Shown on Drawing W7990-0207-ED-01, W7990-0124-ED- } \\
\text { oo Sheets } 1 \text { \& } 2 \text { of } 3\end{array}$ \\
\hline 5.17 & Cranes & 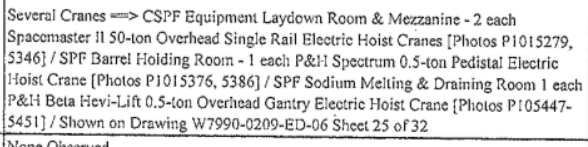 \\
\hline 5.18 & Moving Platforms & None Observed \\
\hline 5.19 & Elevators & None Observed \\
\hline 5.2 & Security & \\
\hline 5.21 & Communication Systems & $\begin{array}{l}\text { Emergency Paging / Communications System was in Good Working Condition - } \\
\text { Several Announcements were made during Walk-down and could be Clearly Heard in } \\
\text { ALL Areas }\end{array}$ \\
\hline 5.22 & Phone and Computer Networks & Did NOr Clieck these Networks at this time \\
\hline 5.23 & Fire Systems & MET-L-X was ONLy Observed Fire Subsystem in Place \\
\hline 5.24 & Fire Detection & Fire Detection in Place in the Sodium Melting and Draining Room \\
\hline 5.25 & Fire Suppression & $\begin{array}{l}\text { The Sodium Metling and Draining Room hats its own Specialized Fire Suppression } \\
\text { System specifially designed for Sodium Fires. The MET-L-X is shown on Drawings } \\
\text { [Plotos P1015368-5369, 5390-5391, 5394] }\end{array}$ \\
\hline 5.26 & Fire Maintenance & Not Know a This Time \\
\hline 5.27 & Criticality Alarms & None Observed \\
\hline 5.28 & Industrial Alarms & O2 Sensors in Sodium Reactor Area \\
\hline 5.29 & Emergency Broadcasting & $\begin{array}{l}\text { Emergency Paging / Communications System was in Good Working Condition - } \\
\text { Several Announcements were made during Walk-down and could be Clearly Heard in } \\
\text { ALL Areass }\end{array}$ \\
\hline
\end{tabular}




\begin{tabular}{|c|c|c|}
\hline 5.3 & HVAC Supply & 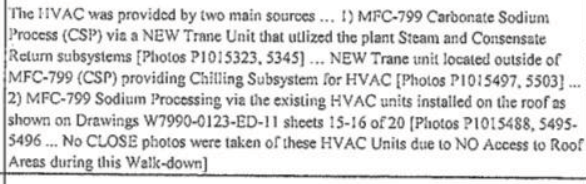 \\
\hline 5.31 & Air filtering & 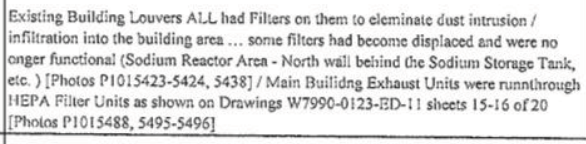 \\
\hline 5.32 & Building Heat & $\begin{array}{l}\text { SFP MFC-799 Building Heat was being maintained during Winter monthis / Plant } \\
\text { Steam and Condensate Return subsysterns were operationat [Plotos P1015323, } 5444 \text { ] / } \\
\text { Main Trane HVAC Units working / Individual Electrical Heater Units Operational in } \\
\text { Sodium Reactor Area for adititional heat }\end{array}$ \\
\hline 5.33 & Building $\mathrm{A} / \mathrm{C}$ & Not Observered as Operational since this was Winter Season \\
\hline 5.34 & Freon Systems & None Observed \\
\hline 5.35 & Shop systems & None Observed \\
\hline 5.36 & Supply Storage & $\begin{array}{l}\text { There were two } 20 \text { foot cargo containers located to NW of the MFC-799 Faielity that } \\
\text { serve as Storage Units for the SPF... Inventories Not Known at this time ... no access } \\
\text { to locked stroage containers during walk-down [Plotos P1015495-5499] } \\
\end{array}$ \\
\hline 5.37 & Change Rooms & None Observed \\
\hline 5.38 & Emergency Response Org & Nol Know a This Time \\
\hline 5.39 & Temporary Structures & None Observed \\
\hline 5.4 & Site Services/Support i.e. Rigging & None Observed \\
\hline 6 & Nuclear Safety \& Materials & \\
\hline & Plutonium & 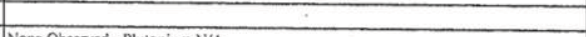 \\
\hline 6.01 & Material in Storage & None Observed - Plutonium N/A \\
\hline 6.02 & In Solution & None Observed - Plutonium N/A \\
\hline 6.03 & In Equipment & None Observed - Plutonium N/A \\
\hline 6.04 & In Glove Boxes & None Observed - Plutonium N/A \\
\hline 6.05 & In Hot Cells & None Observed - Plutonium N/A \\
\hline 6.06 & In Cells, Sumps & None Observed - Plutonium N/A \\
\hline 6.07 & In Ducts & None Observed - Plutonium N/A \\
\hline 6.08 & In HEPA Filters & None Observed - Plutonium N/A \\
\hline 6.09 & Sump or Pool Sludge & None Observed - Plutonium N/A \\
\hline & Uranium or Thorium & \\
\hline 6.1 & Material in Storage & None Observed - Uranitm or Thoritum N/A \\
\hline 6.11 & In Solution & None Observed - Uranium of Thorium N/A \\
\hline 6.12 & In Equipment & None Observed - Uranium or Thorium N/A \\
\hline 6.13 & In Glove Boxes & None Observed - Uranium or Thorium N/A \\
\hline 6.14 & In Hot Cellis & None Observed - Uranium or Thoorium N/A \\
\hline 6.15 & In Cells, Sumps & None Observed - Uranium or Thoorium N/A \\
\hline 6.15 & In Ducts & None Observed - Uranium or Thorium N/A \\
\hline 6.16 & In HEPA Filters & None Observed - Uranium or Thorium N/A \\
\hline 6.17 & Sump or Pool Sludge & None Observed - Uranium or Thoorium N/A \\
\hline & Nuclear Fuel & \\
\hline 6.18 & New in Storage & None Observed-Nuclear Fuel N/A \\
\hline 6.19 & In Reactor & None Observed - Nuclear Fuel N/A \\
\hline 6.2 & In Wet Storage & None Observed -Nuclear Fuel N/A \\
\hline 6.21 & In Dry Storage & None Observed -Nuclear Fuel N/A \\
\hline & $\mathrm{TRU}-(\mathrm{am}, \mathrm{cm}, \mathrm{bk}, \mathrm{cf})$ & \\
\hline 6.22 & Material in Storage & None Observed - TRU N/A \\
\hline 6.23 & In Solution & None Observed - TRU N/A \\
\hline 6.24 & In Equipment & None Observed - TRU N/A \\
\hline 6.25 & In Glove Boxes & None Observed - TRU N/A \\
\hline 6.26 & In Hot Cells & None Observed - TRU N/A \\
\hline 6.27 & In Cells, Sumps & None Observed - TRU N/A \\
\hline 6.28 & In Ducts & None Observed - TRU N/A \\
\hline 6.29 & In HEPA Filters & None Observed - TRU N/A \\
\hline 6.3 & Sump or Pool Sludge & None Observed - TRU N/A \\
\hline & Other Nuclear Materials & 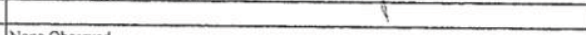 \\
\hline 6.31 & Deuterium. Tritium, Lithium 6 & None Observed \\
\hline 6.32 & Sealed Sources & MFC-770C - Nuclear Calibration Laboratory \\
\hline 6.33 & Source Accountability & Not Known at this Time \\
\hline 6.34 & Neutron Monitors & None Observed \\
\hline 6.35 & Neutron Absorbers & None Observed \\
\hline 6.36 & In line Neutron Source & None Observed \\
\hline 7 & Hazardous Material & \\
\hline & Process Chemicals & \\
\hline 7.01 & Acids & None Observed \\
\hline 7.02 & Caustics & $\begin{array}{l}\text { Caustic Subbystem - Chemical makeup } \rightarrow \text { Specific Chemical Constituents and } \\
\text { Concentrations are being provided by BEA / See MSDS (Malerial Safety Data Sheets) } \\
\text { on Caustic }\end{array}$ \\
\hline 7.03 & Sodium & $\begin{array}{l}\text { Sodium Subsystemss - Limiled amounis of Radioactive Contamination / See MSDS } \\
\text { (Material Safety Data Sheets) on Sodium Metals }\end{array}$ \\
\hline 7.04 & Hydrazine & None Observed \\
\hline 7.05 & Lab Reagents & None Observed \\
\hline 7.06 & Misc. Chemicals or Expiosives & None Observed \\
\hline & $\begin{array}{l}\text { Environmental Hazards } \\
\text { Lead, Heavy Metals }\end{array}$ & \\
\hline$\frac{7.07}{7.09}$ & $\begin{array}{l}\text { Lead, Heavy Metals } \\
\text { Potassium Chromate }\end{array}$ & \begin{tabular}{|l} 
None Observed \\
None Observed \\
\end{tabular} \\
\hline 7.08 & $\begin{array}{l}\text { Potassium Chromate } \\
\text { PCBs }\end{array}$ & None Observed \\
\hline 7.1 & Solvents and thinners & None Observed \\
\hline 7.11 & Freon, CFC's & None Observed \\
\hline 7.12 & Paints, Sealants, Adhesives & None Observed \\
\hline
\end{tabular}




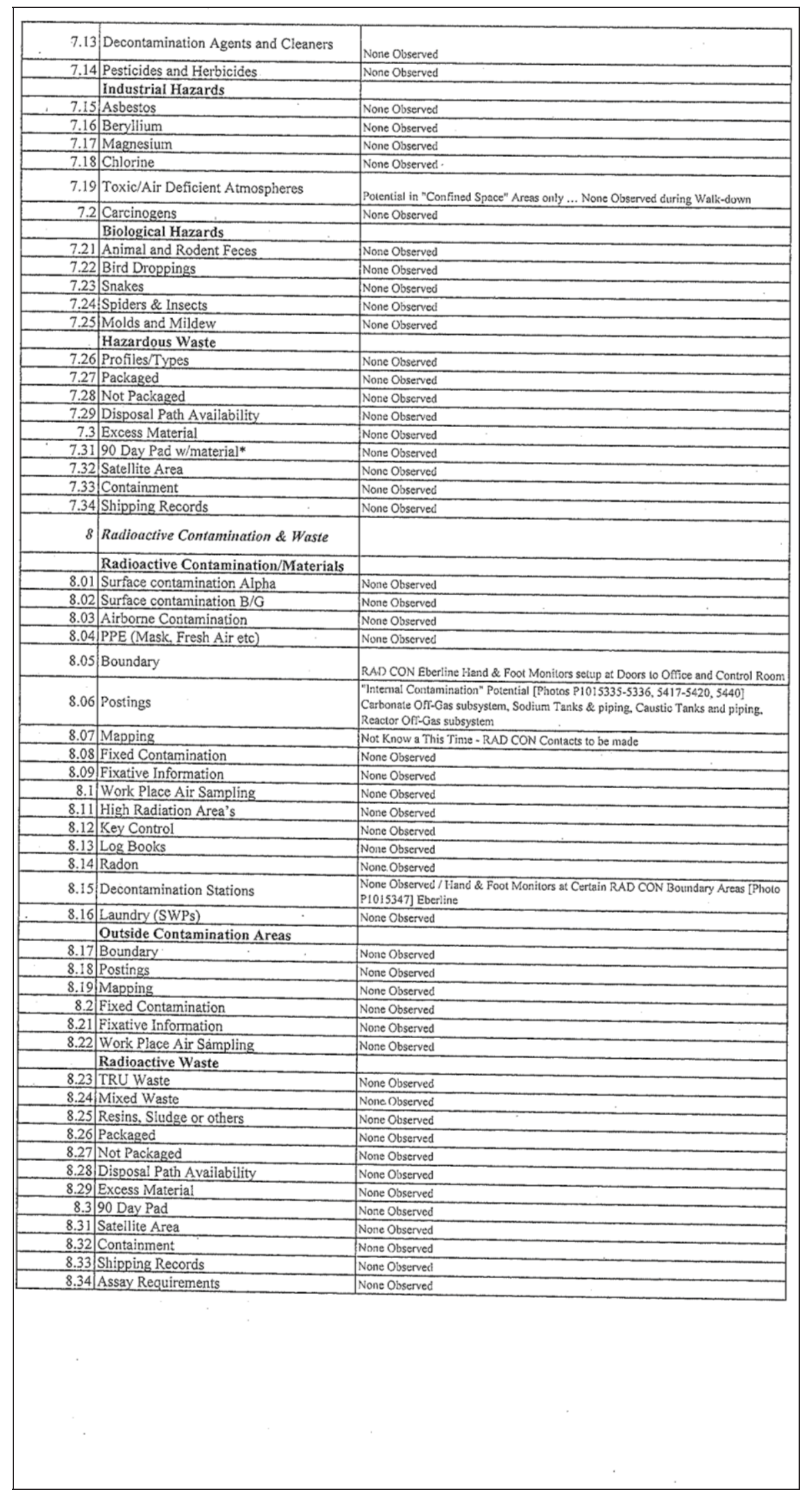


Appendix B

\section{Drawings}




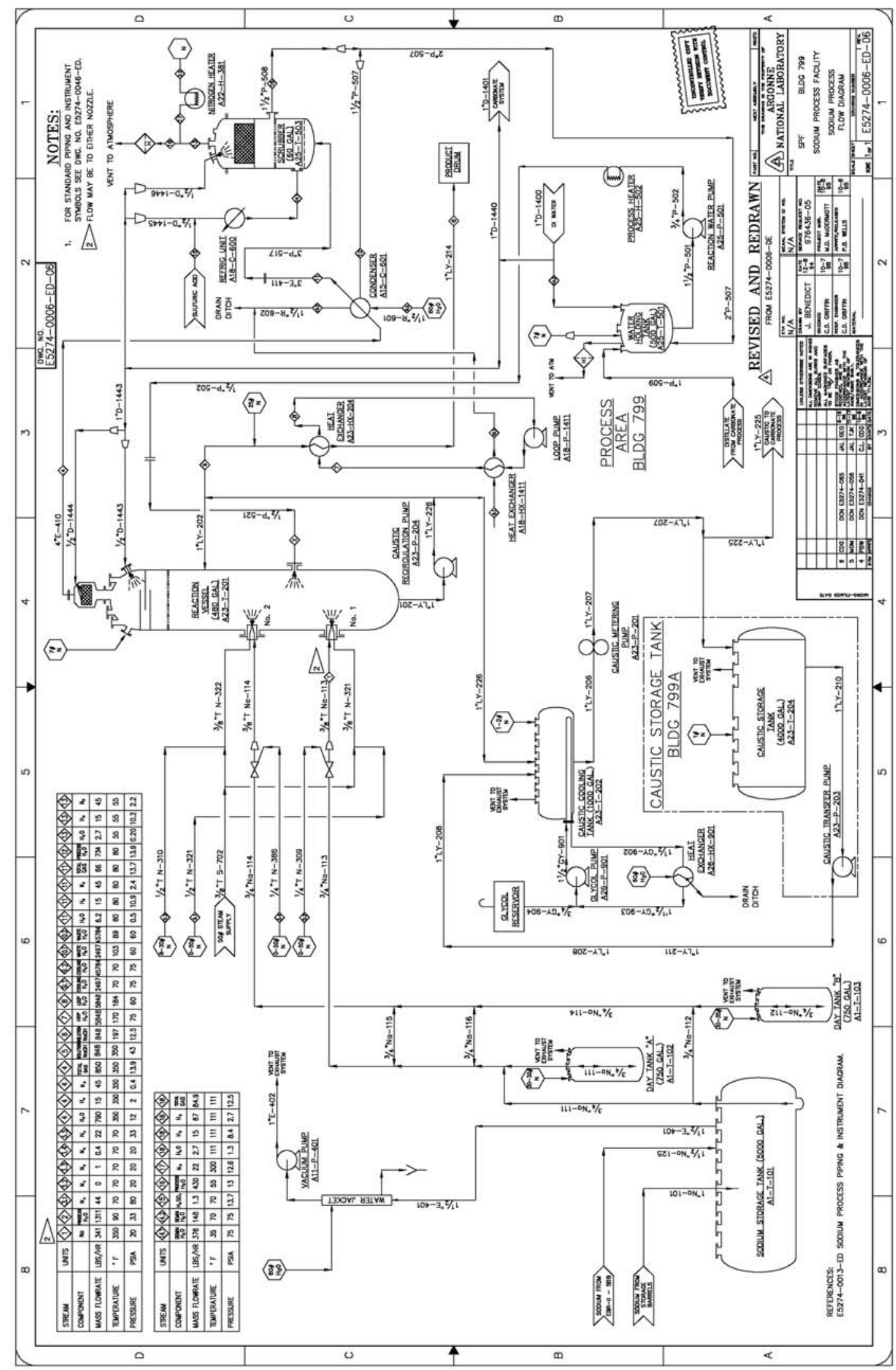




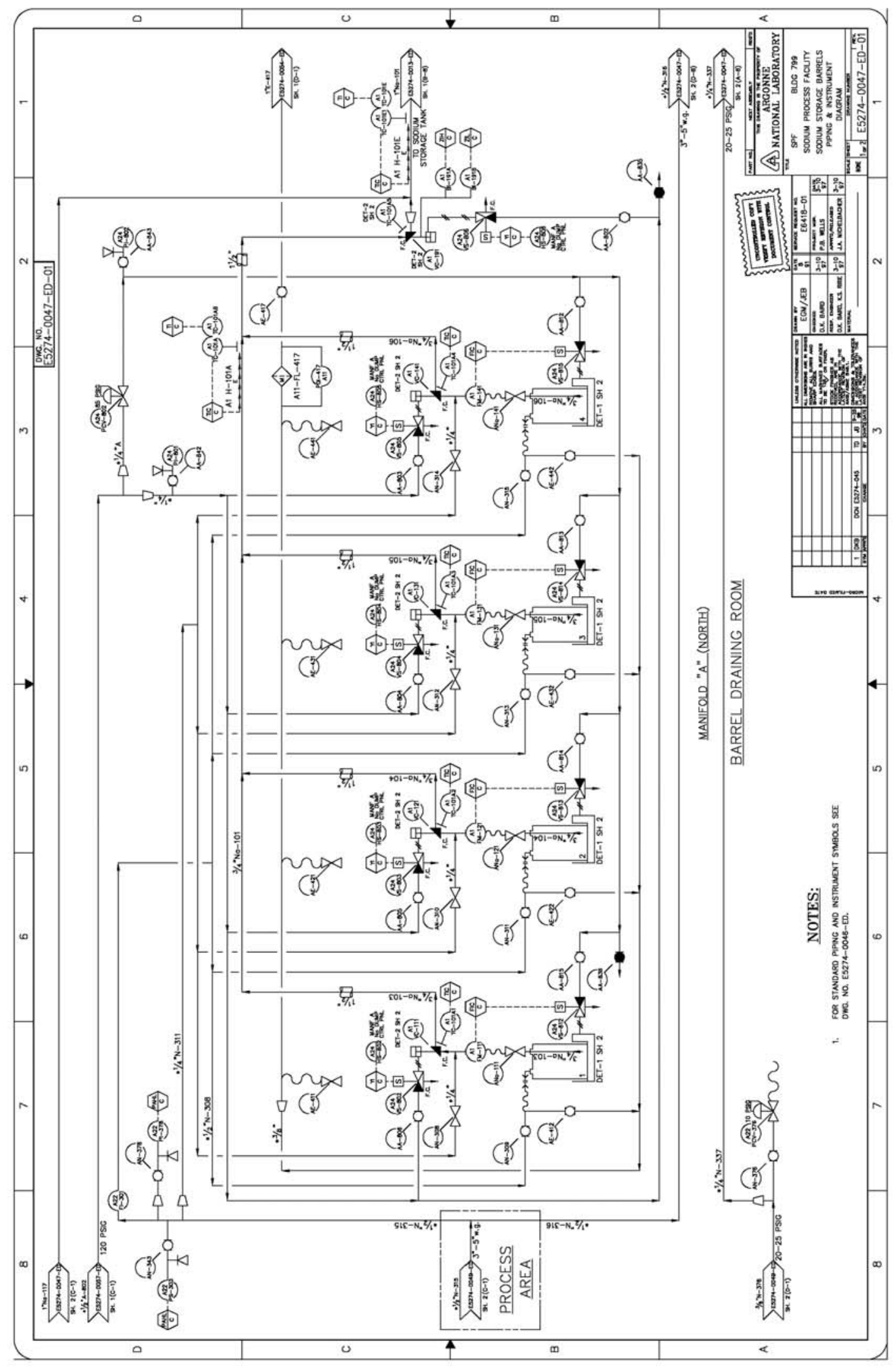




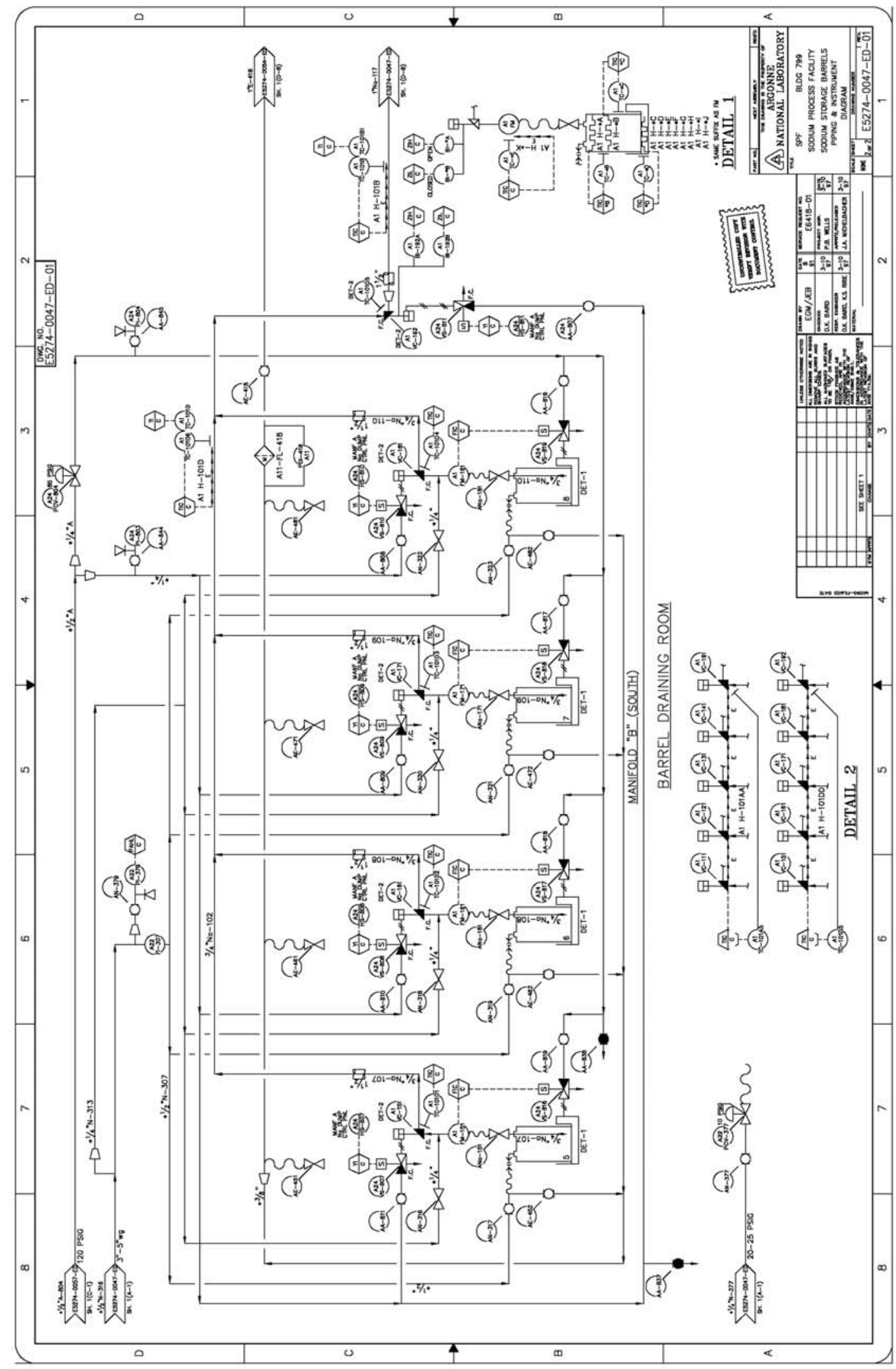




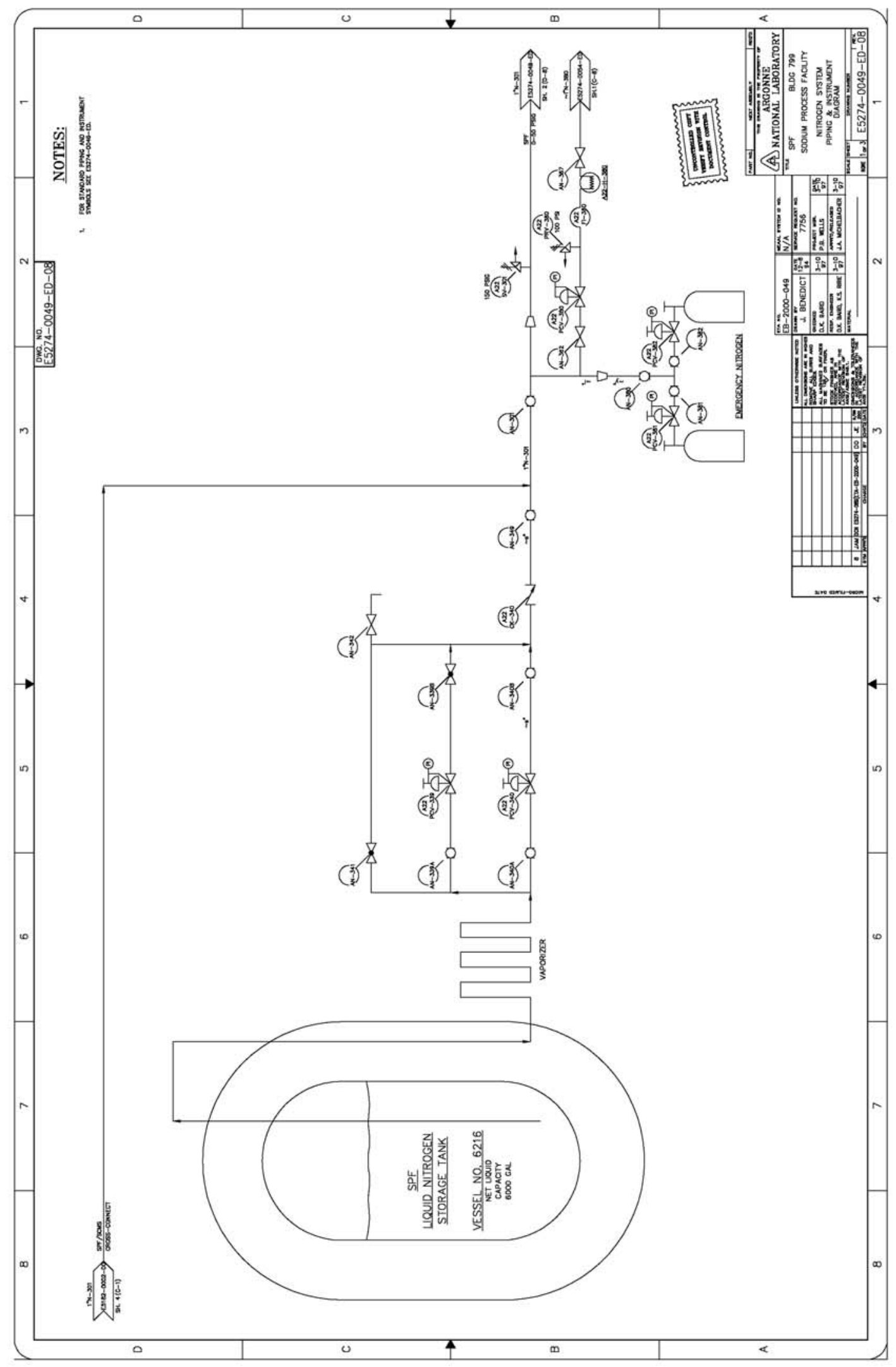




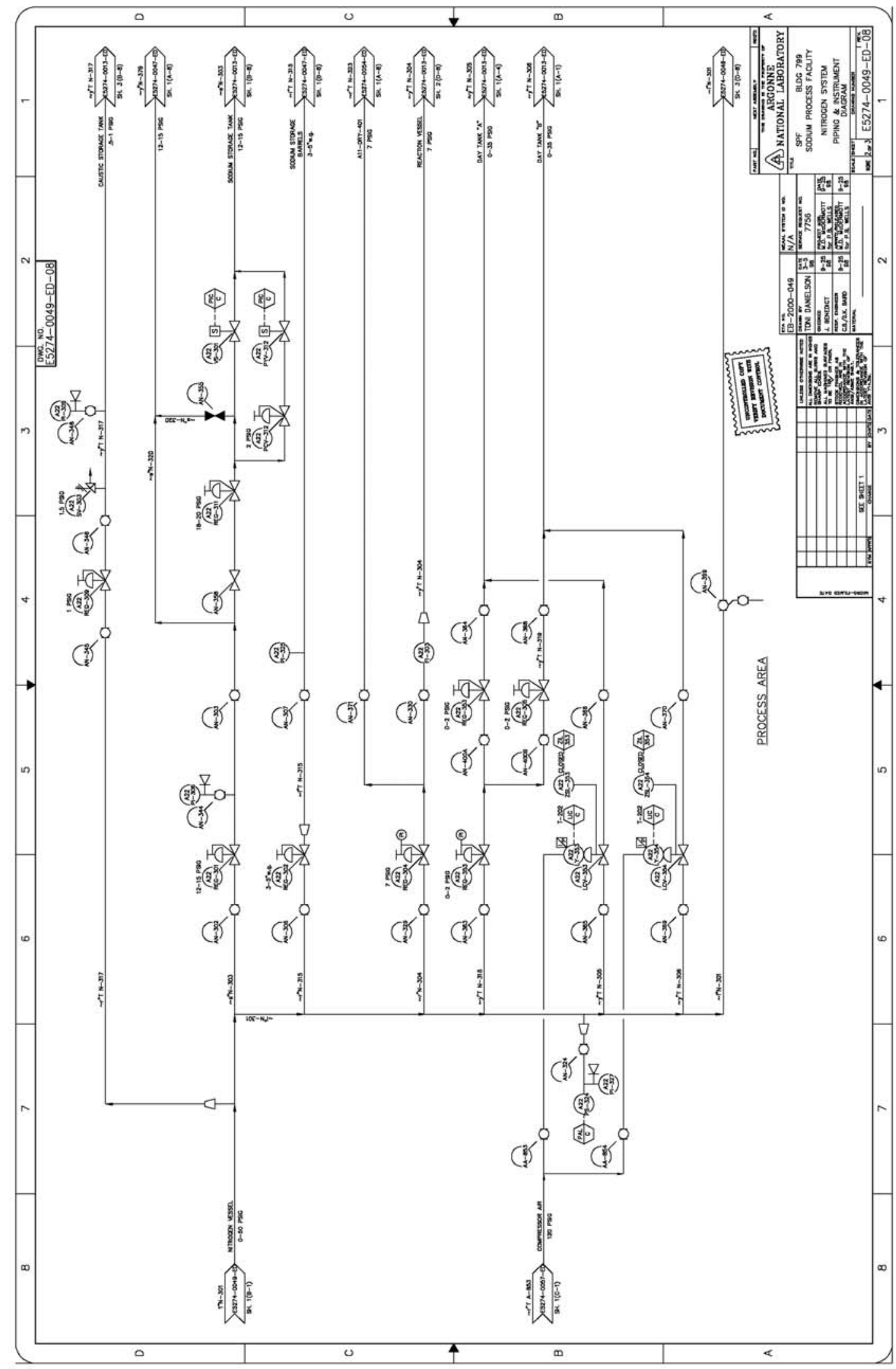




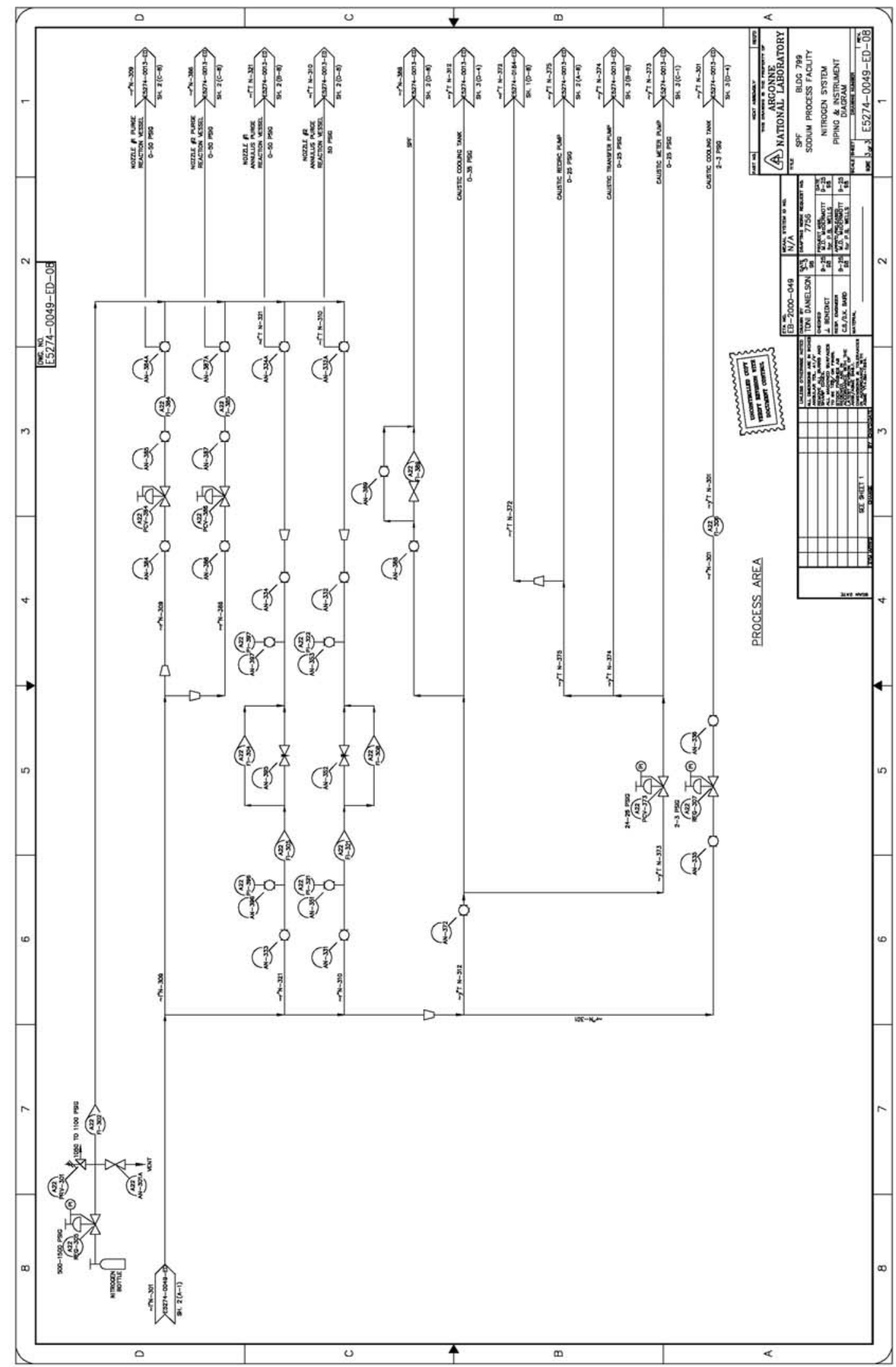









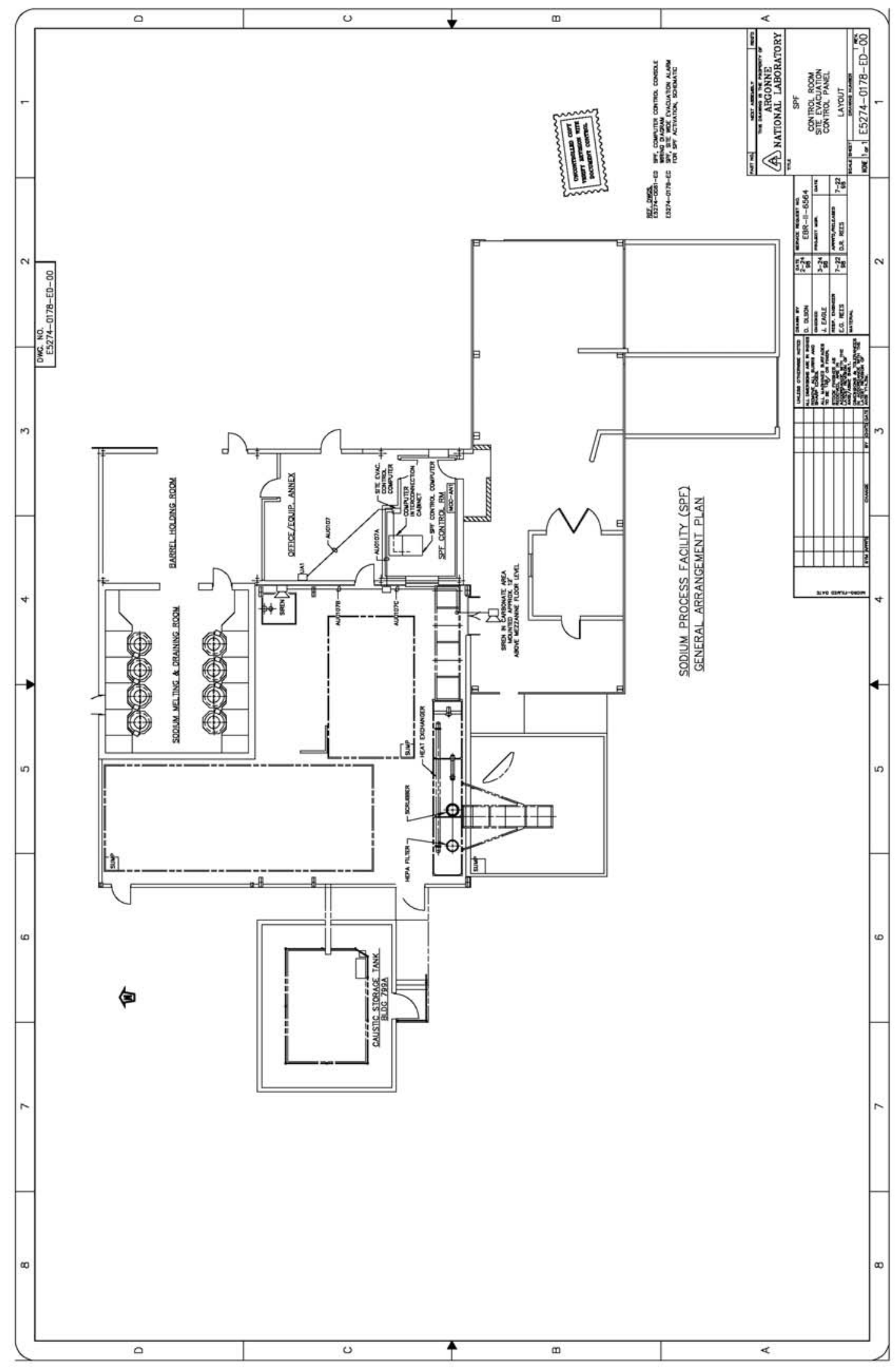




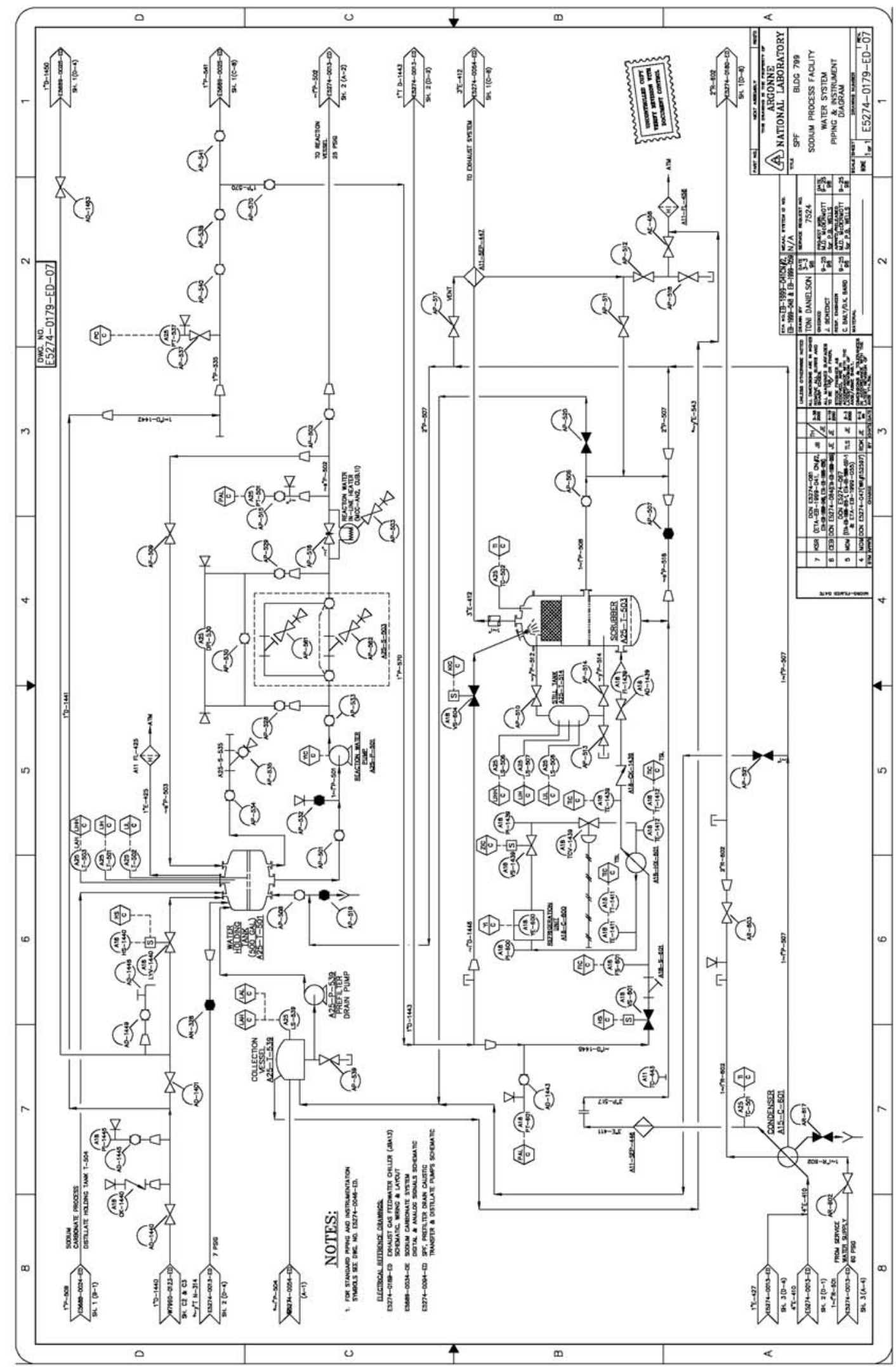




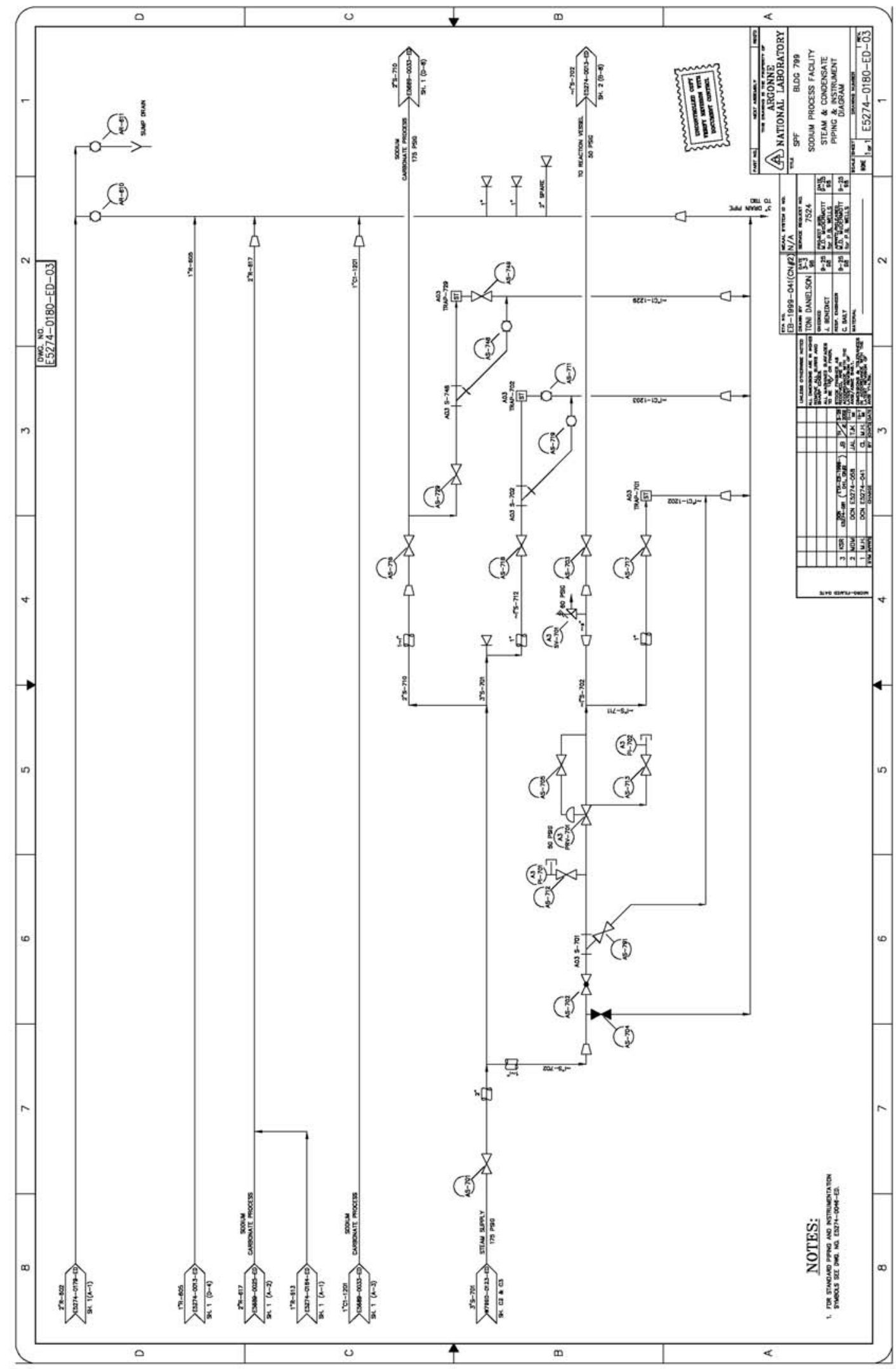




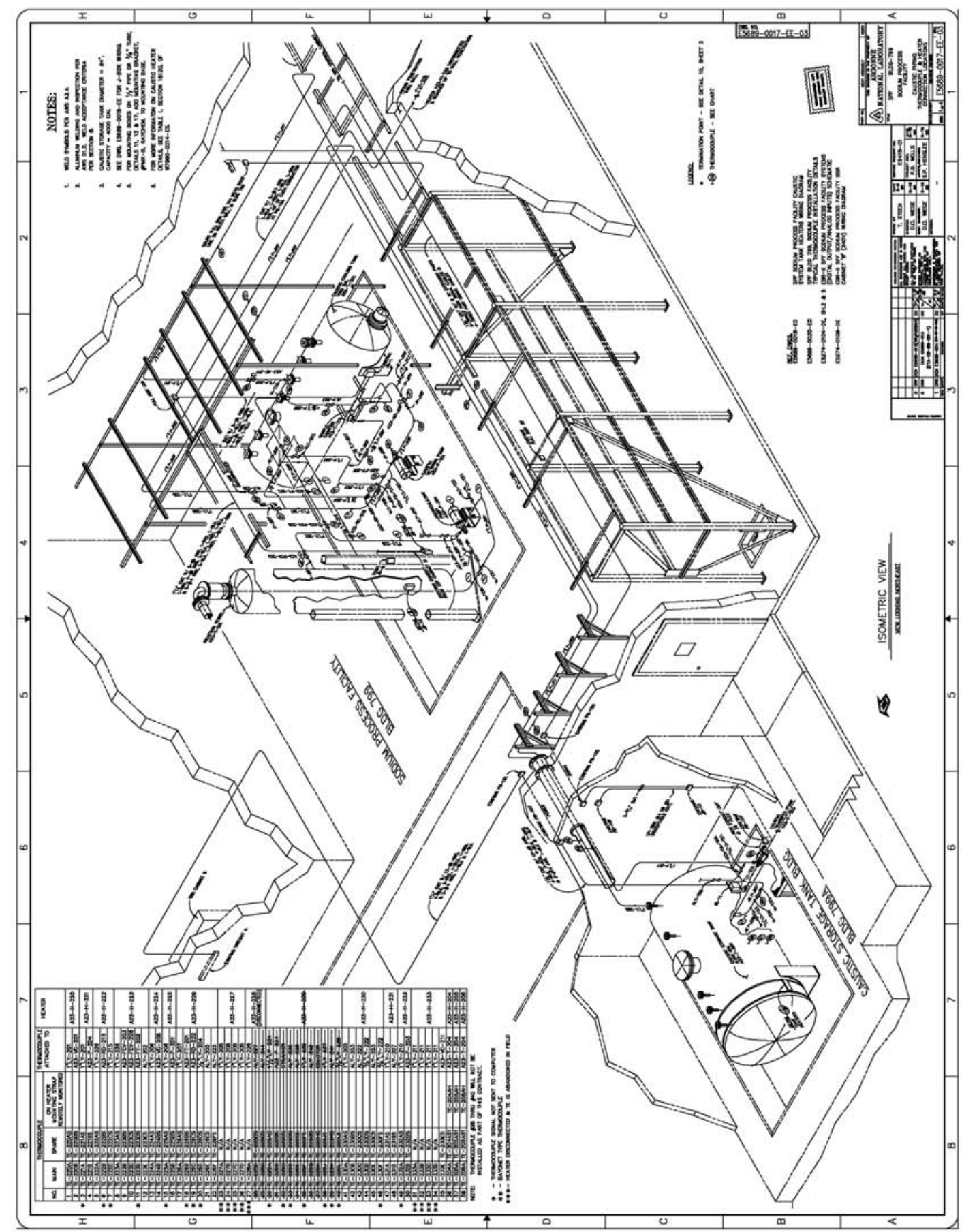




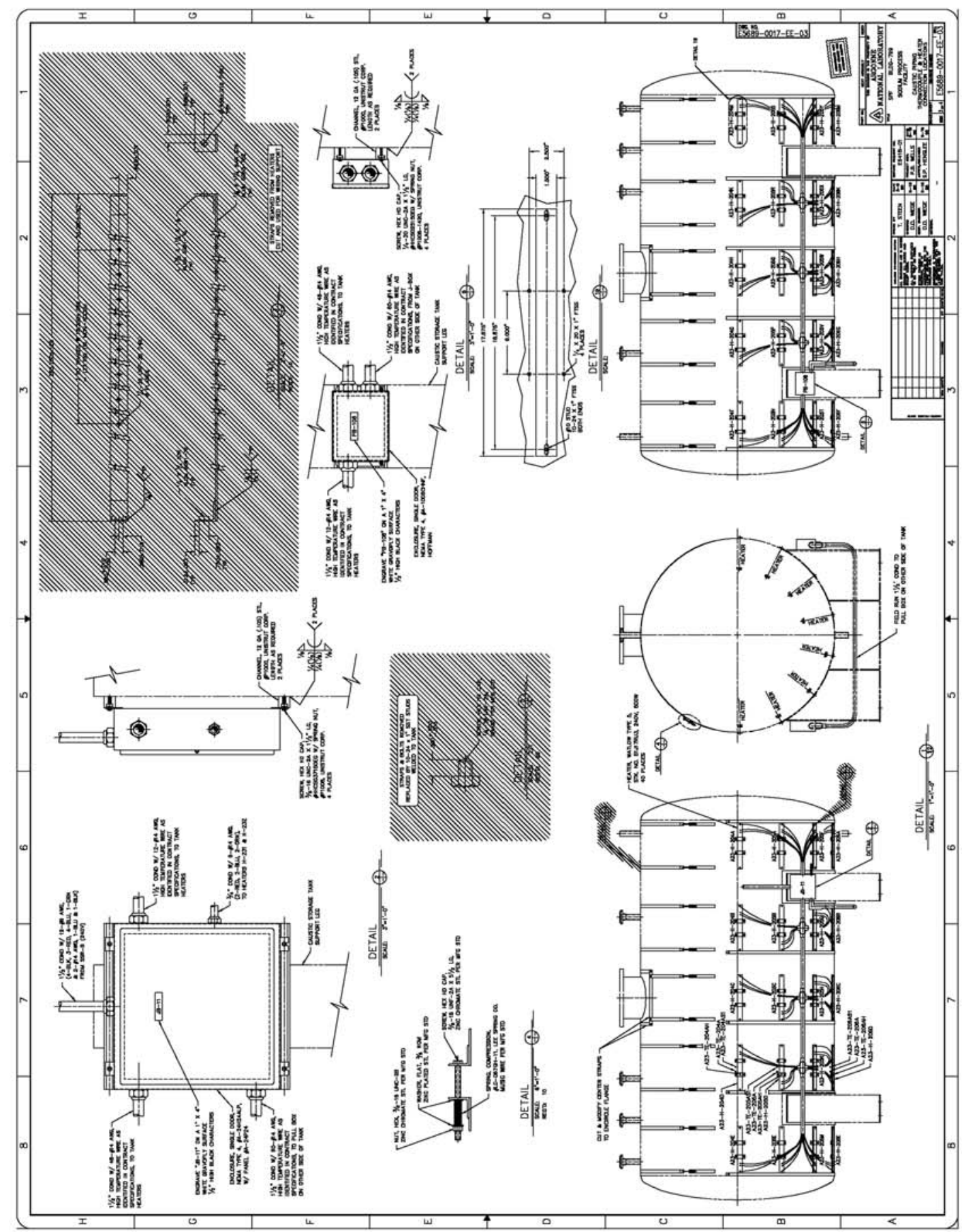




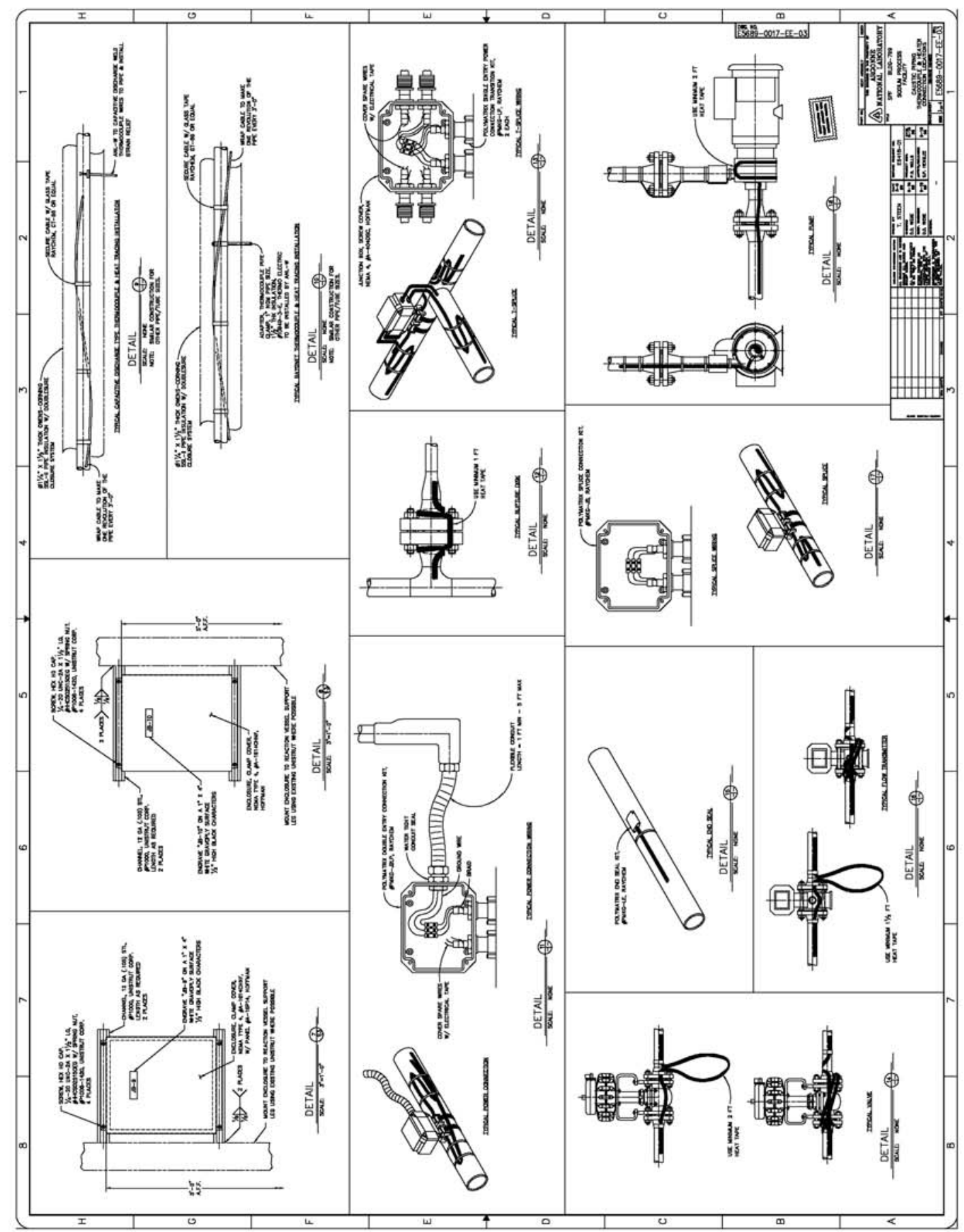




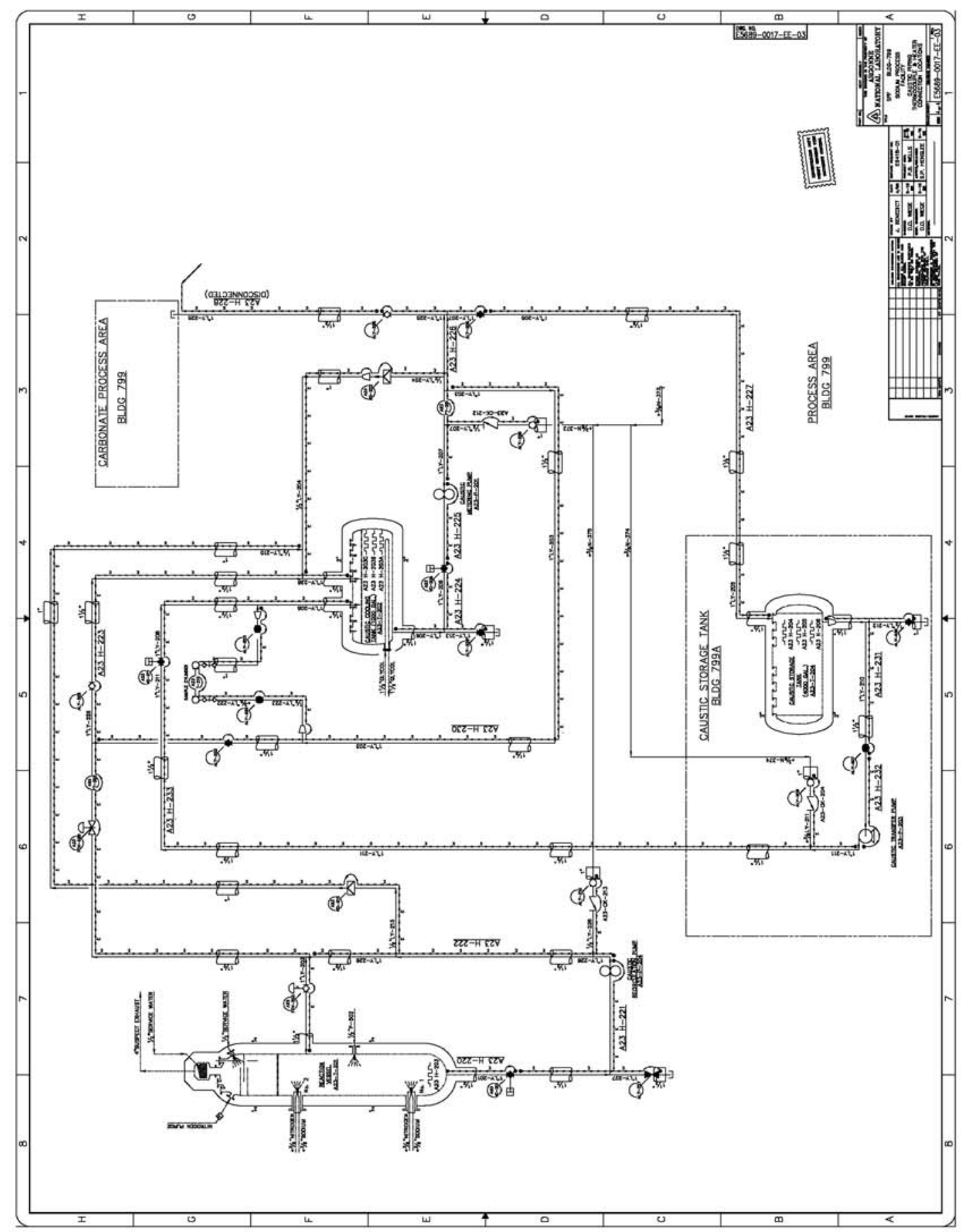




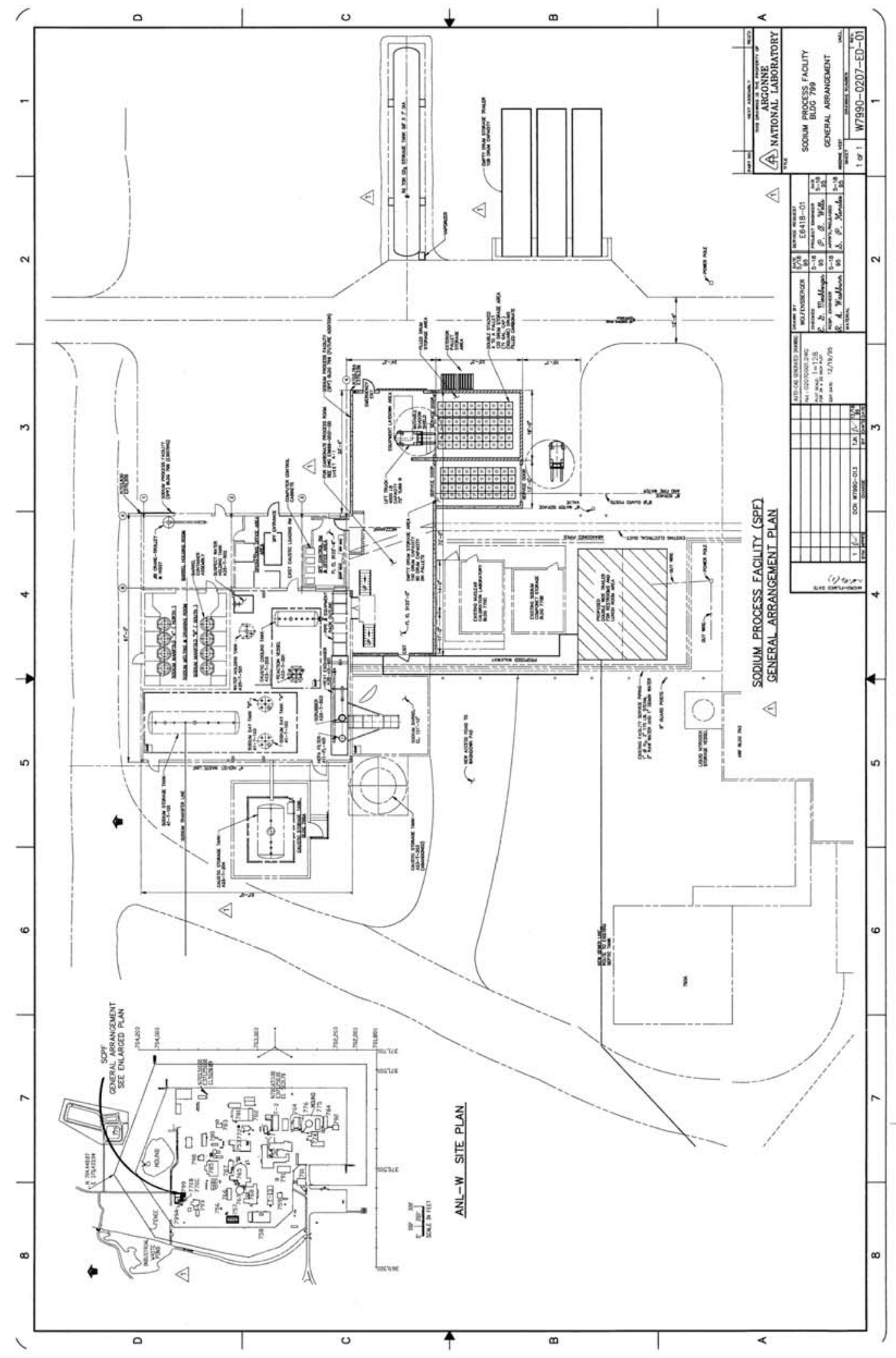




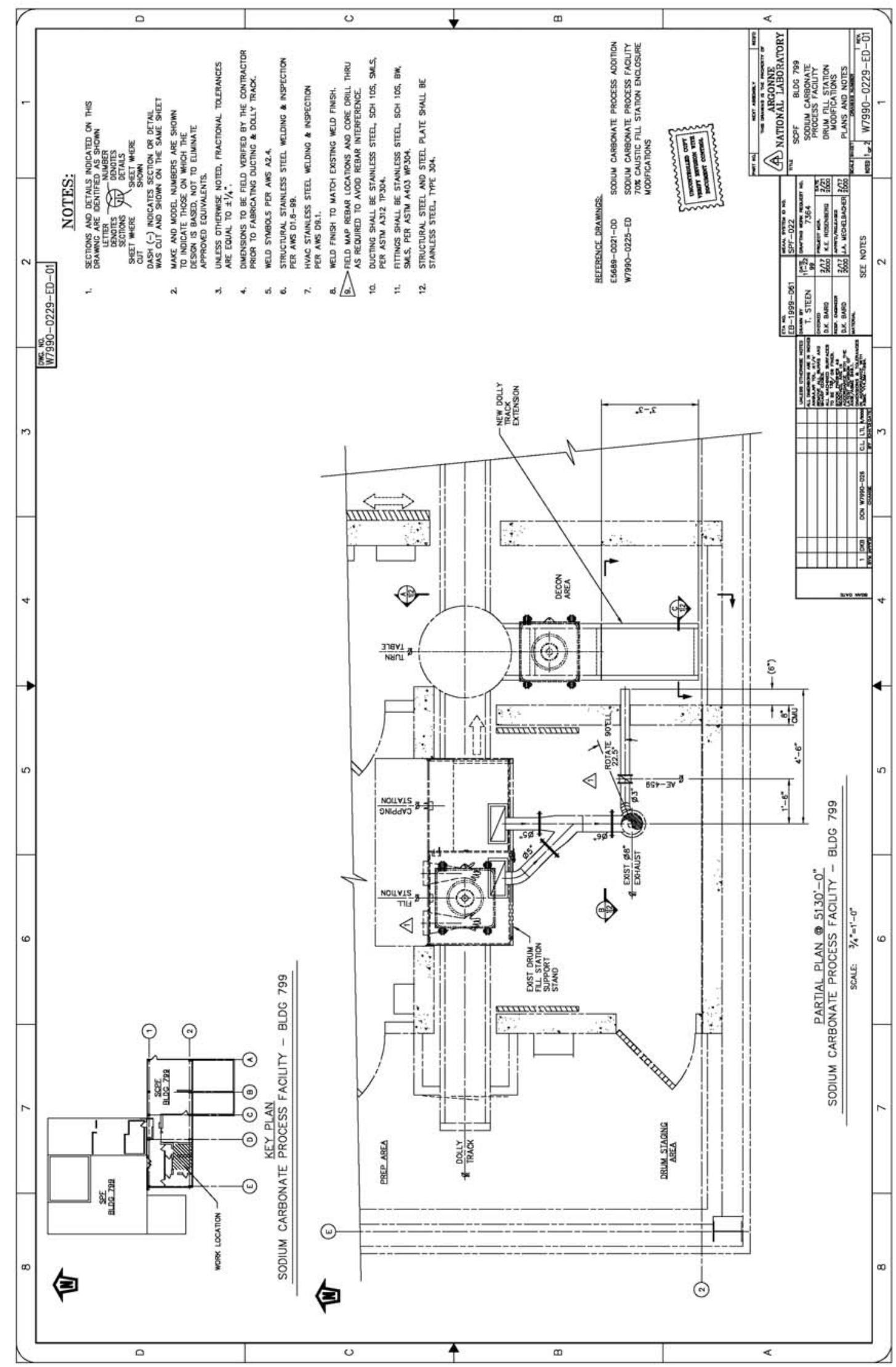




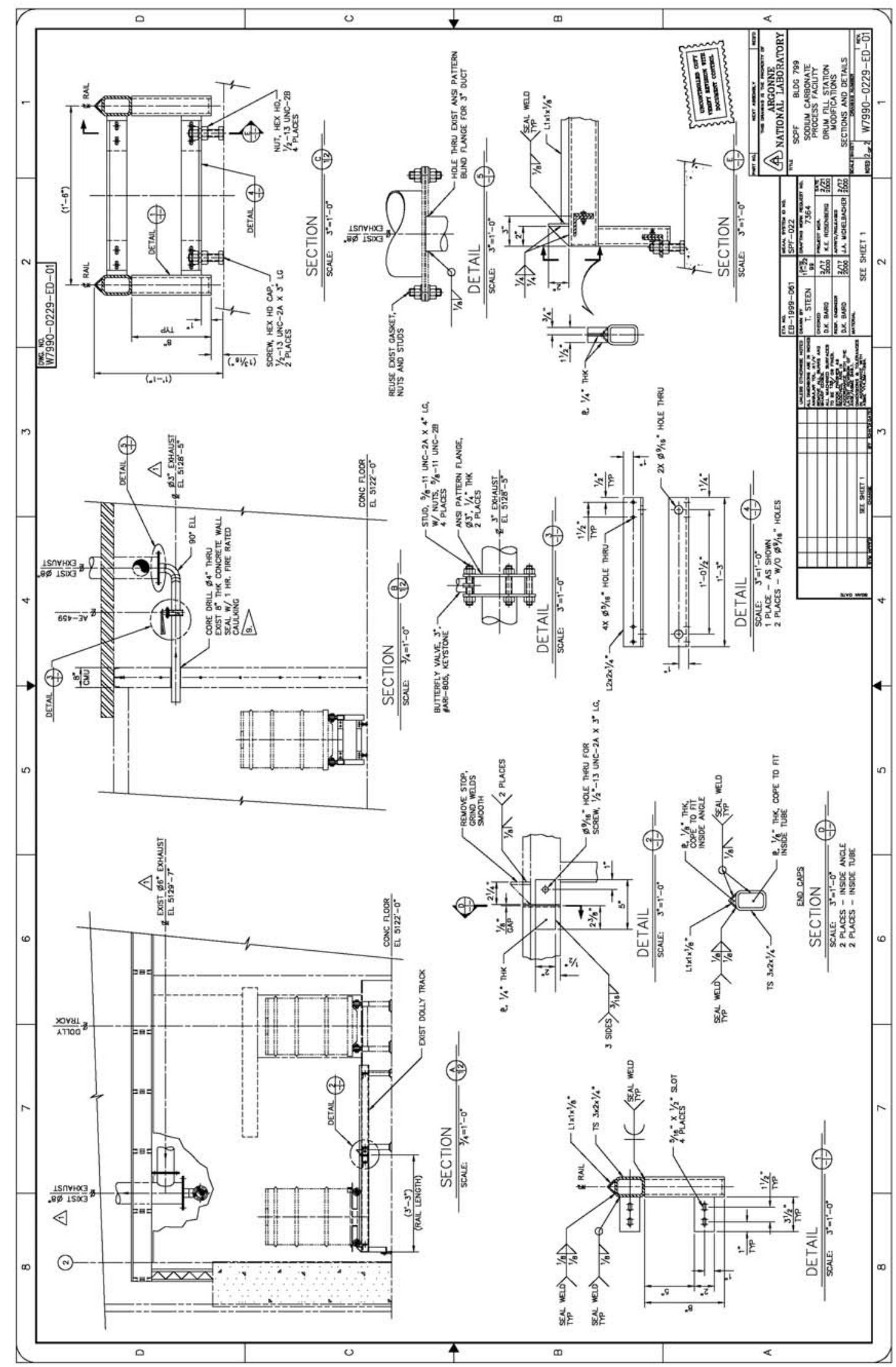


Appendix C

\section{Photographs}


MFC-799, 799A, 770B, and 770C Photo Description Log

Sodium Processing Facility MFC-799 - Equipment Laydown Area

P1015258

Filled Drum Room (looking south)

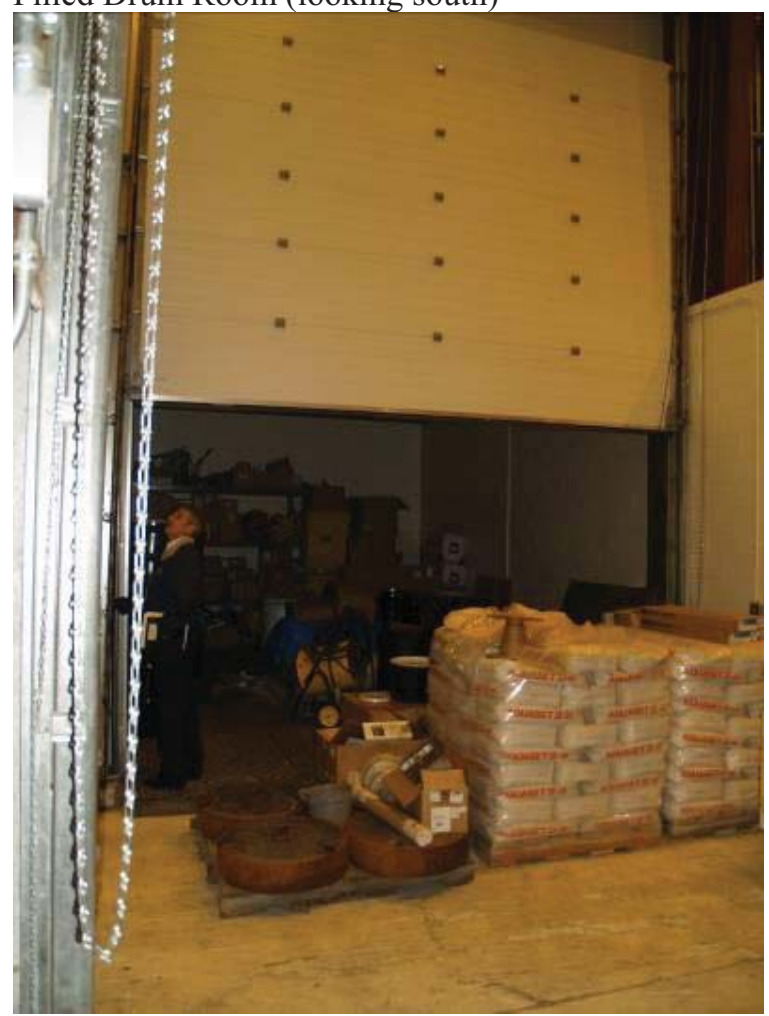


P1015259

Equipment Laydown Area (looking east)

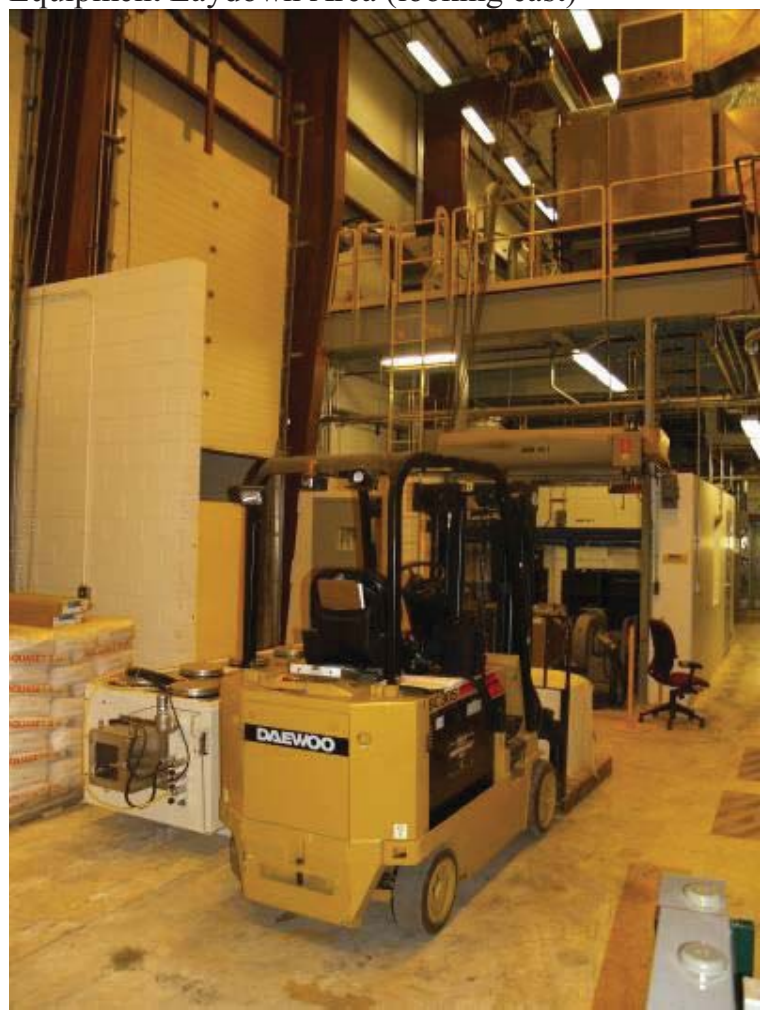

P1015260

Equipment Laydown Area (looking east)

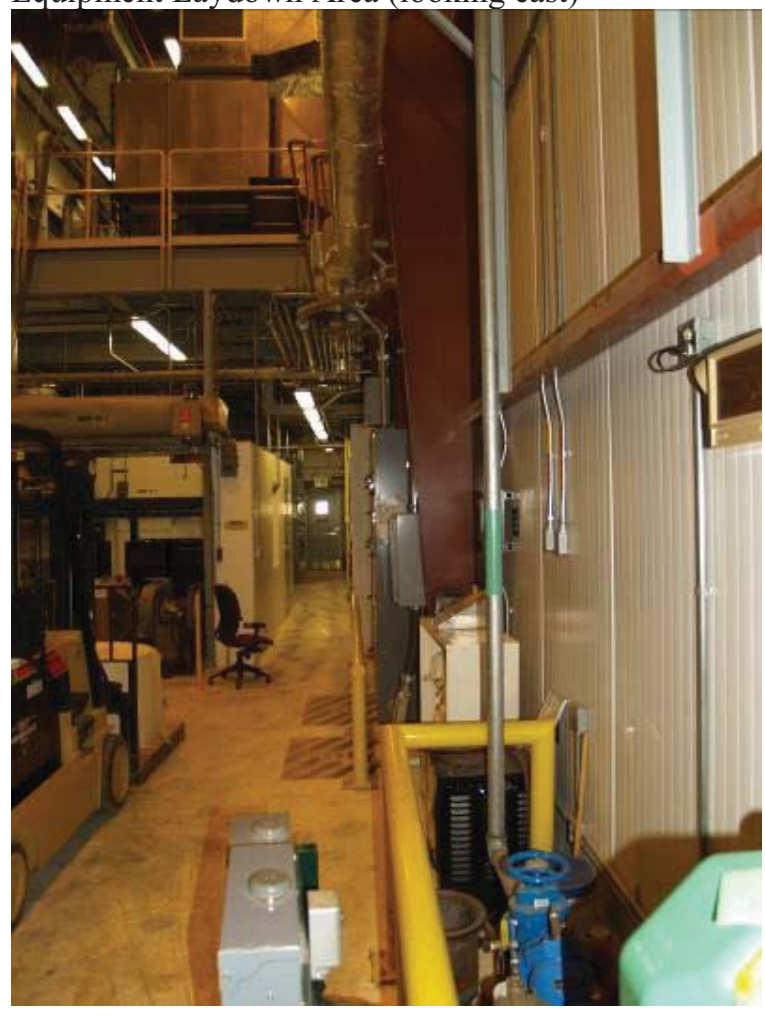


P1015261

Eyewash Station/Potable Water Lines/Portable Unit

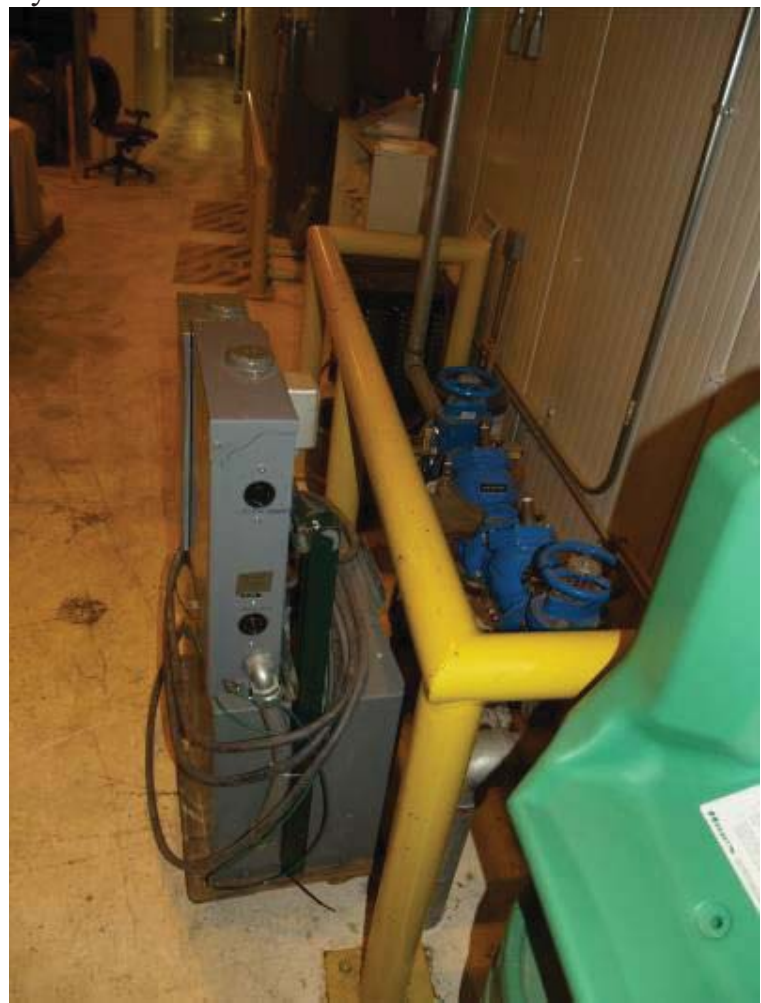

P1015262

Filled Drum Room/Excess Storage

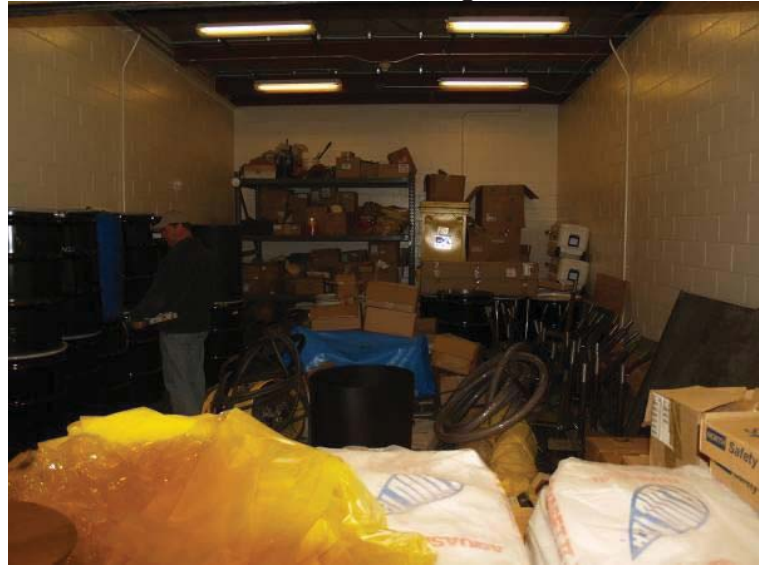


P1015263

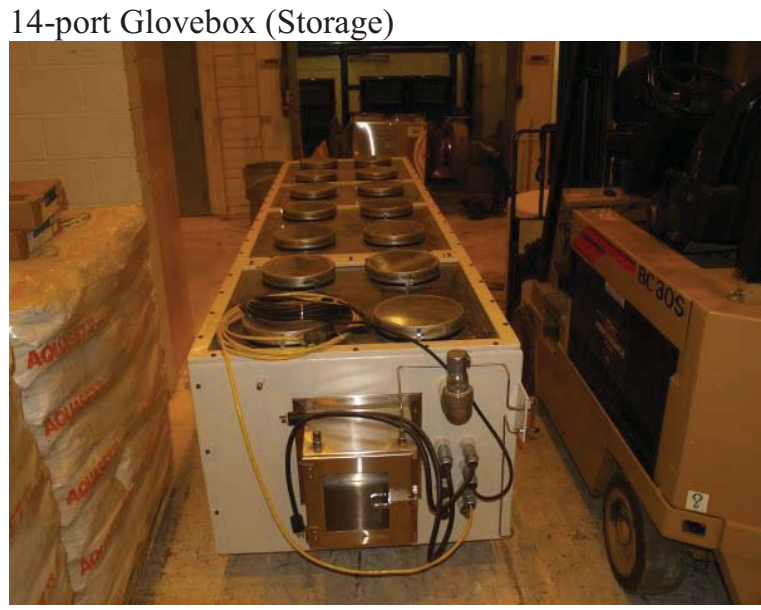

P1015264

Daewoo BC30S Electric Forklift

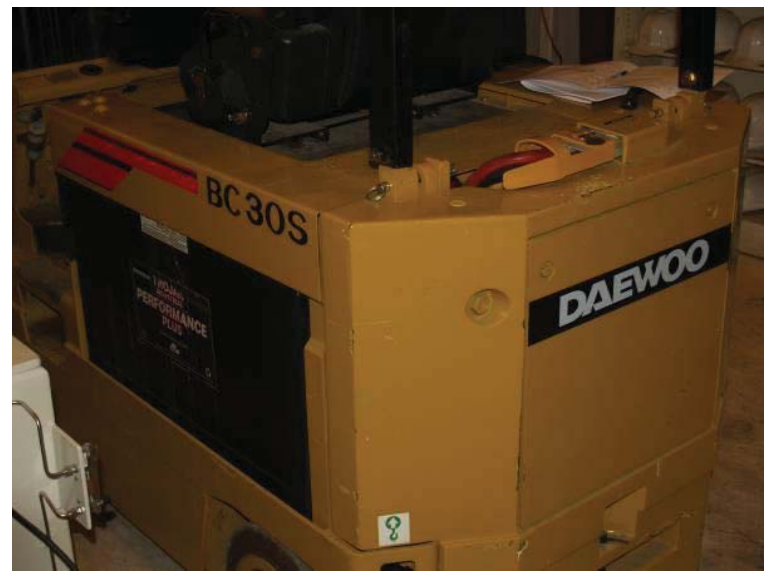

P1015265

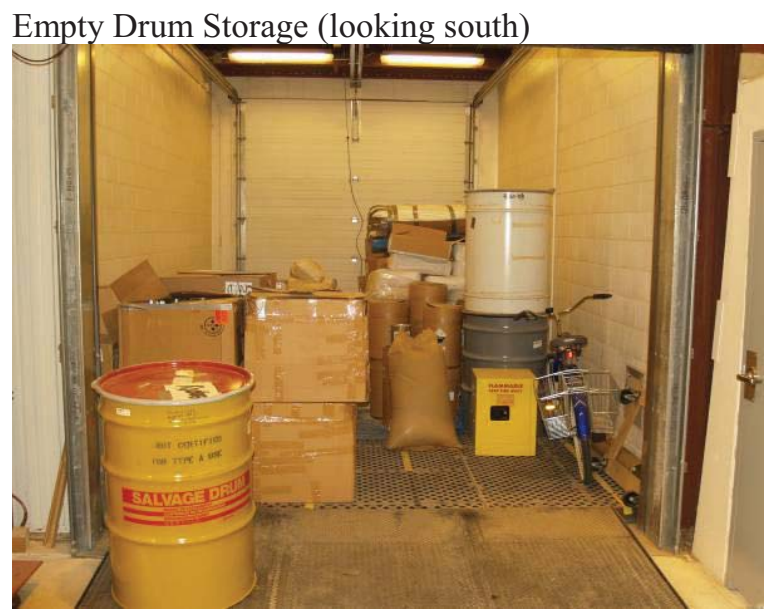


P1015266

Outside Empty Drum Storage Room/Spill Cabinet

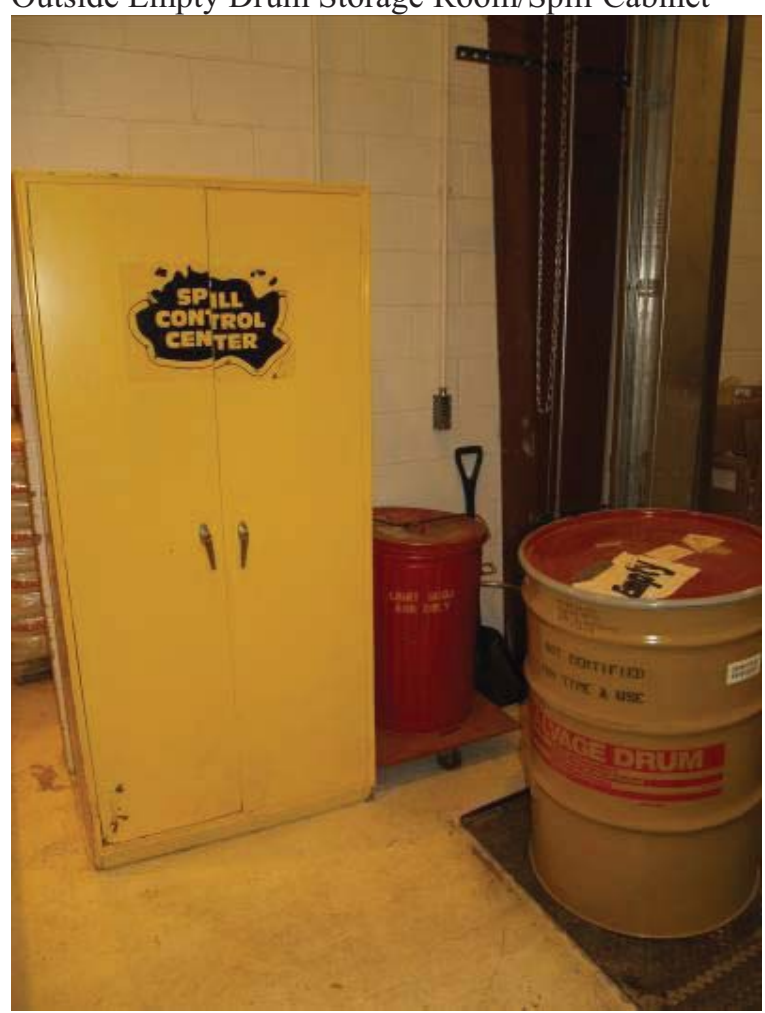

P1015267

Portable HEPA (Outside Drum Filling Room)

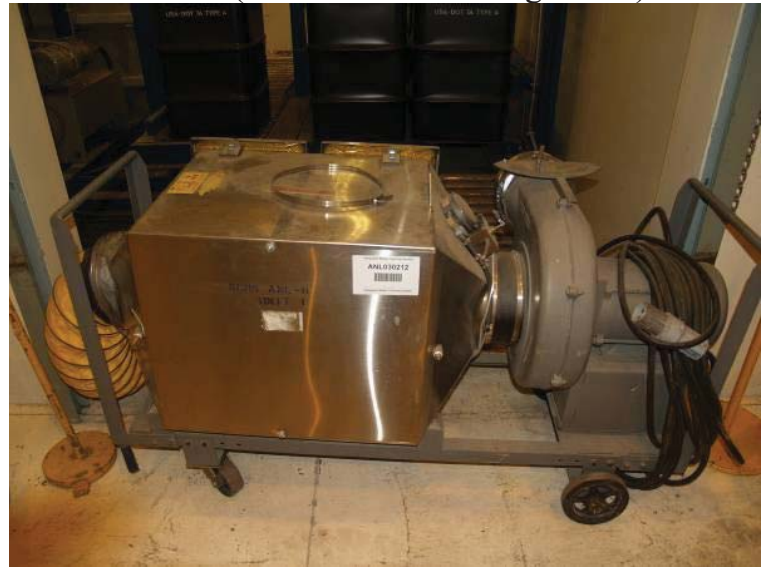


P1015268

Drum Filling Room (looking west)

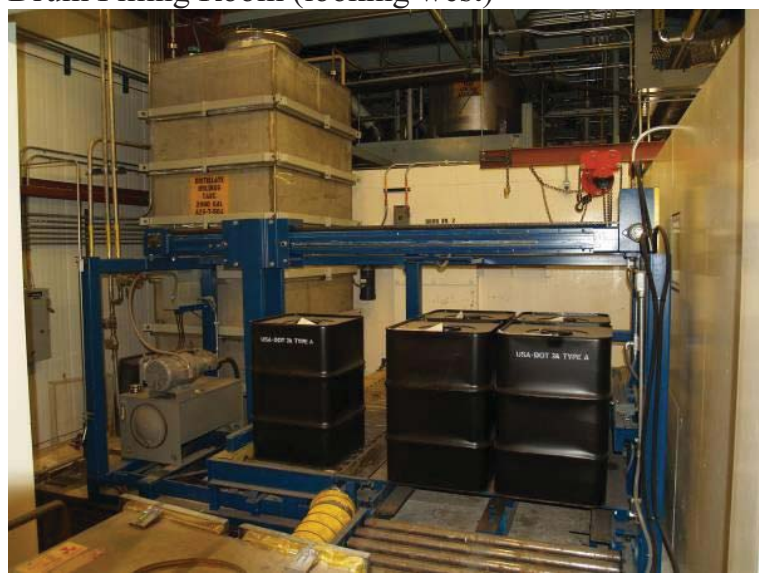

P1015269

MCC-AE1 (north wall, Equipment Laydown Area)

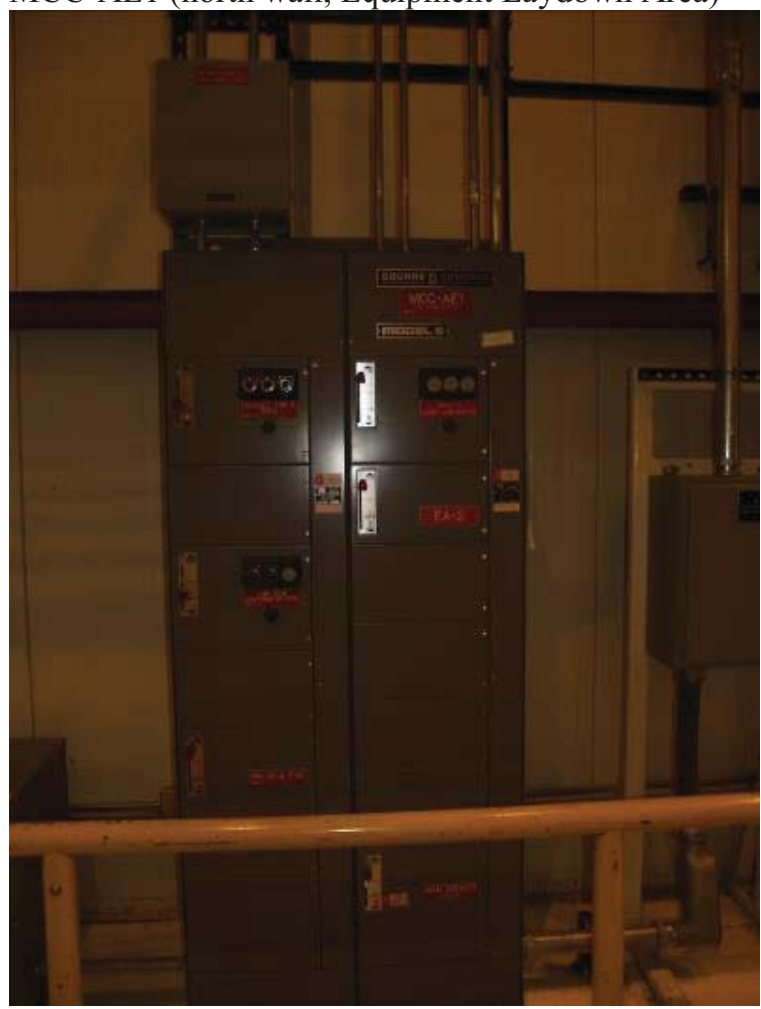


P1015270

Junction Box JB-200/Forklift Battery Disconnect (north wall, Equipment Laydown Area)

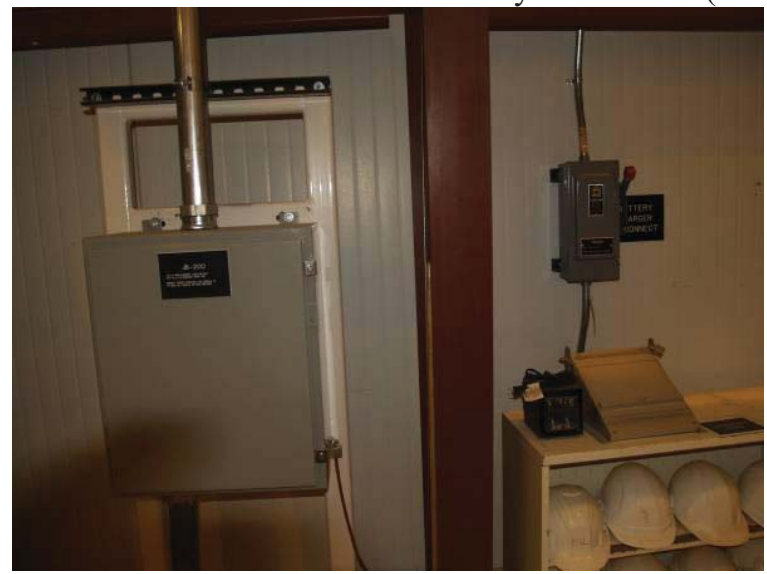

P1015271

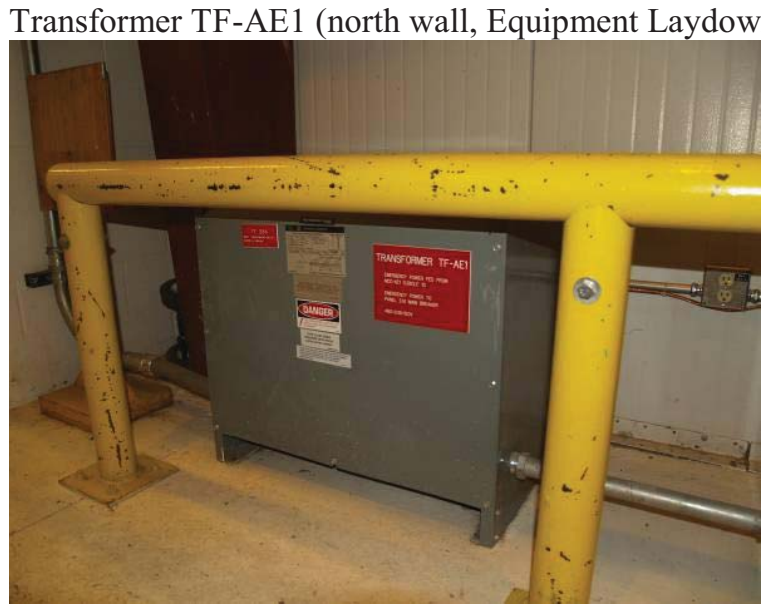


P1015272

Equipment Laydown Area (looking west)

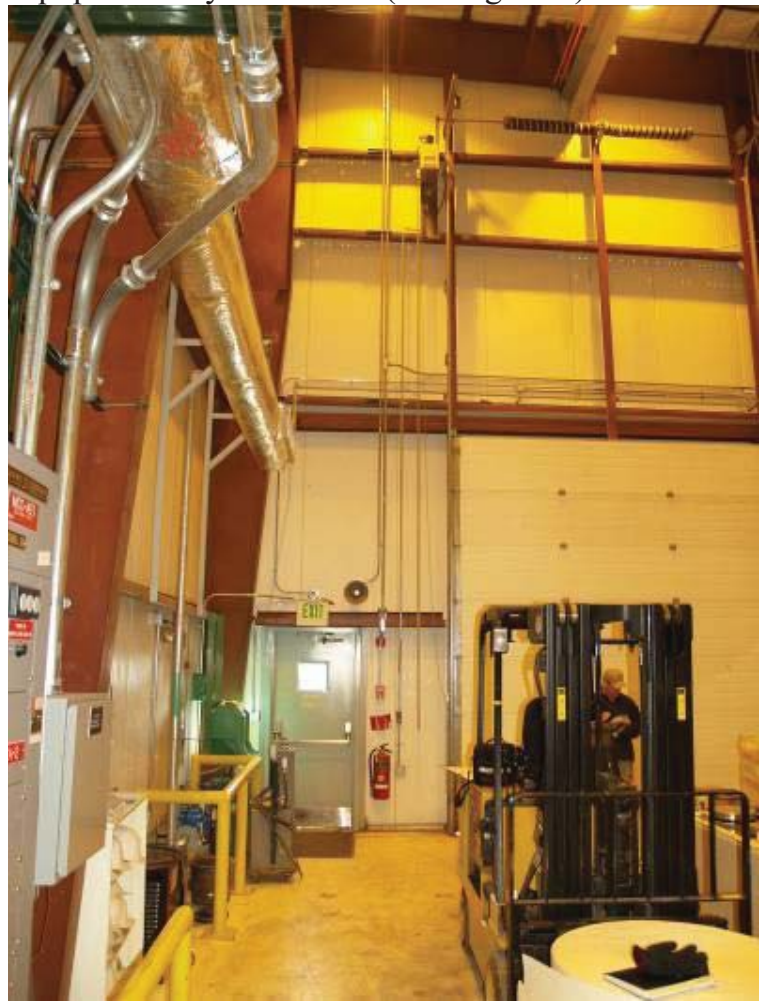

P1015273

Equipment Laydown Area (looking southwest)

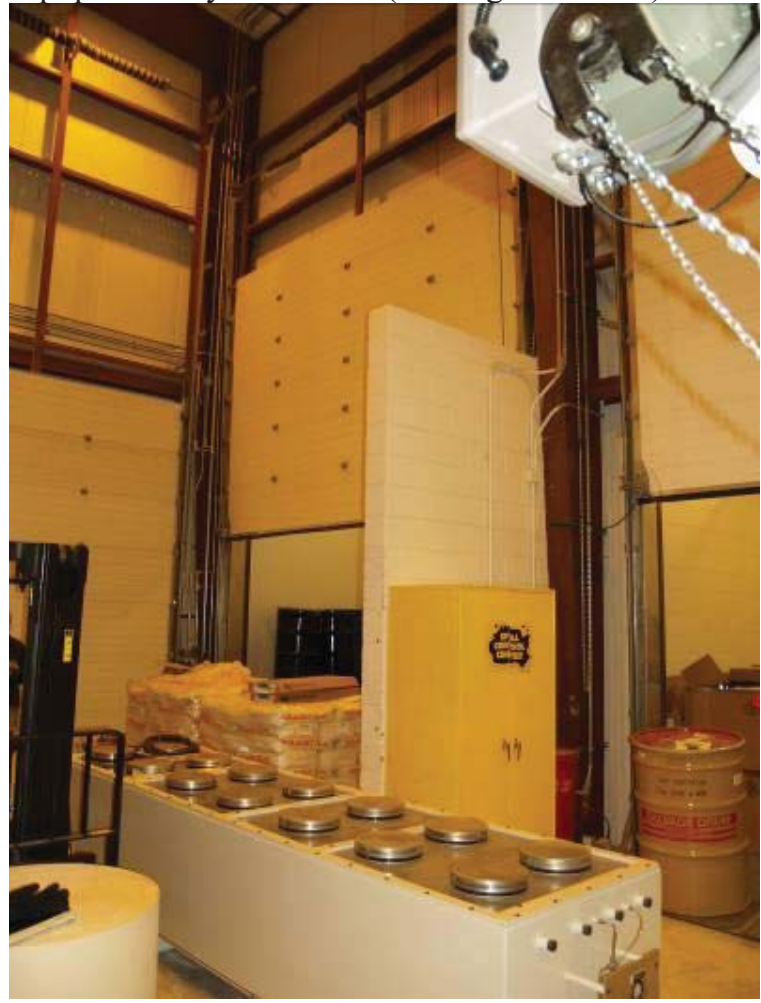


P1015274

Empty Drum Room (south view)

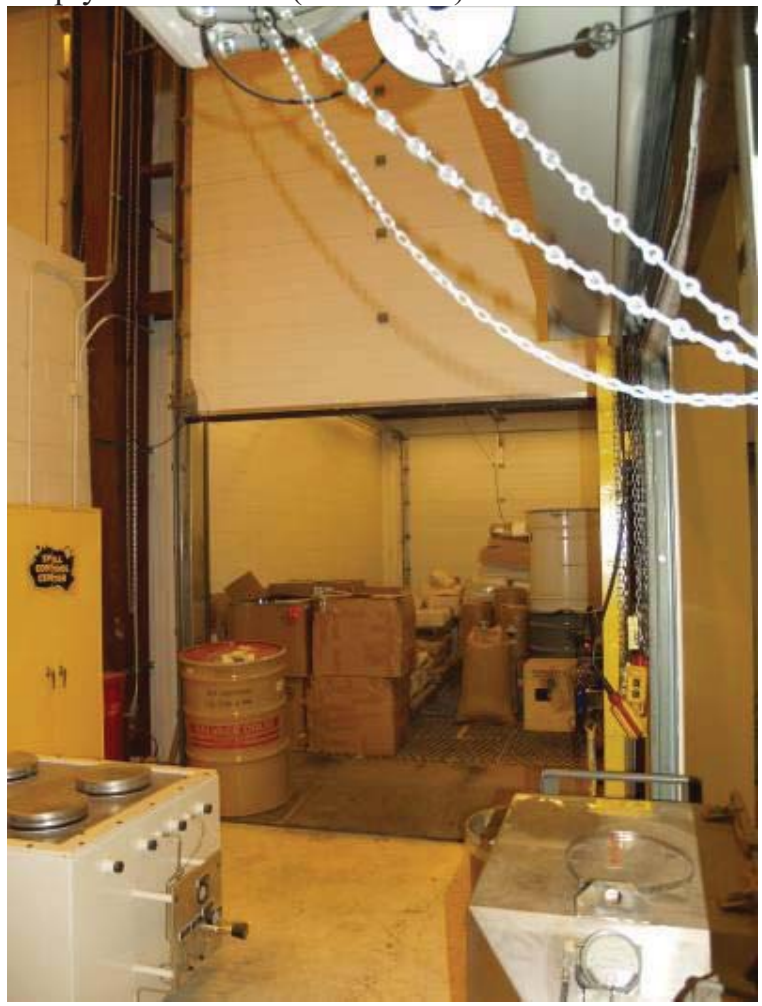

P1015275

Stored Glovebox Instrument Panel

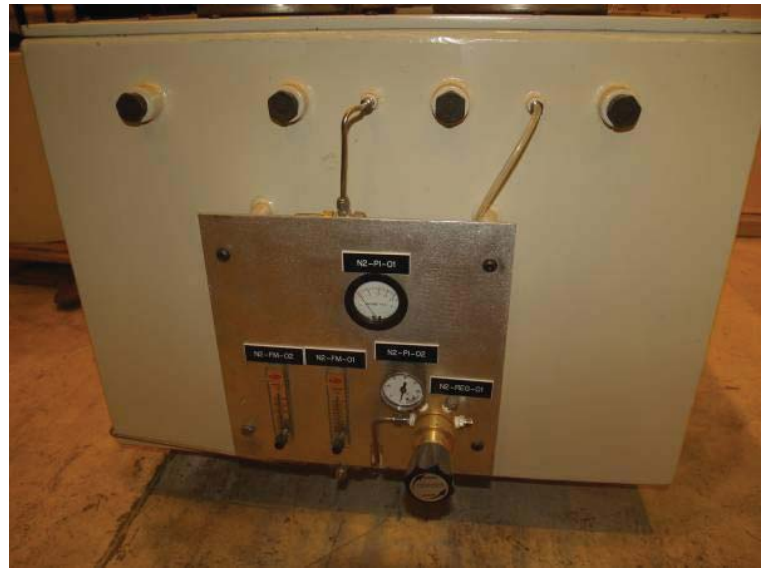


P1015276

P1015277
Forklift Battery Charger (Trojan II)

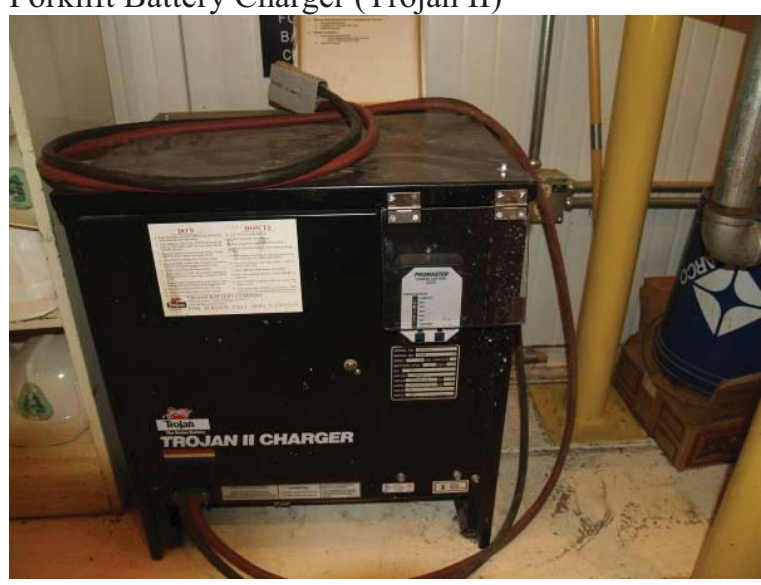

Eyewash Station (northwest man door, Equipment Laydown Area)

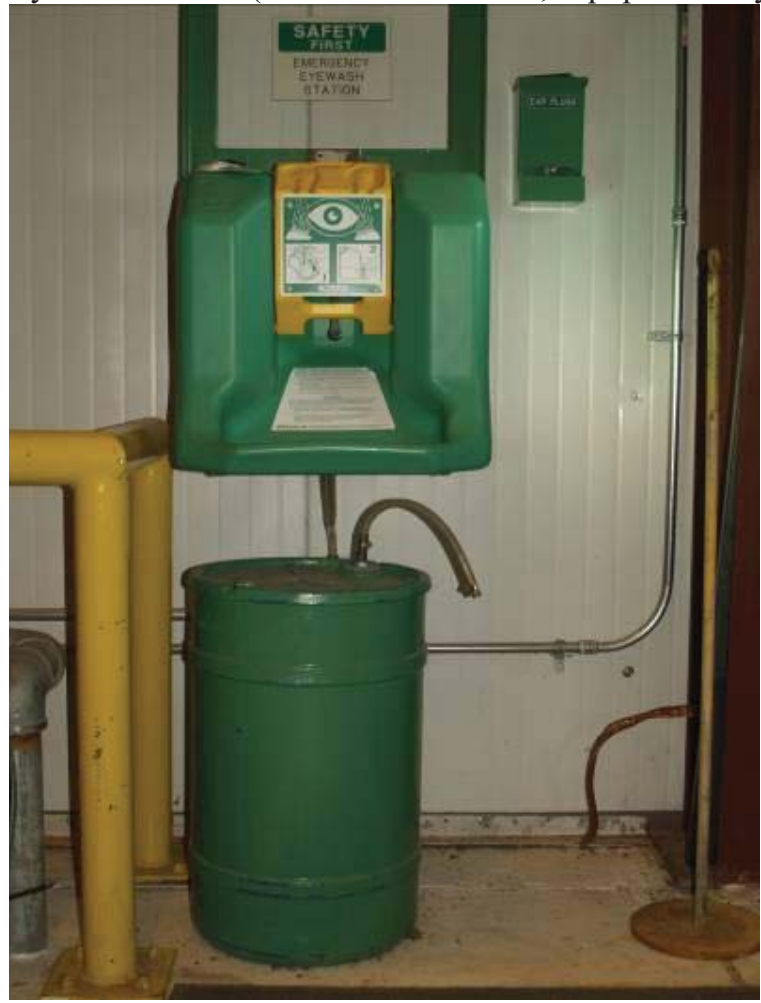


P1015278

Exit/Fire Alarm/Extinguisher (northwest man door, Equipment Laydown Area)

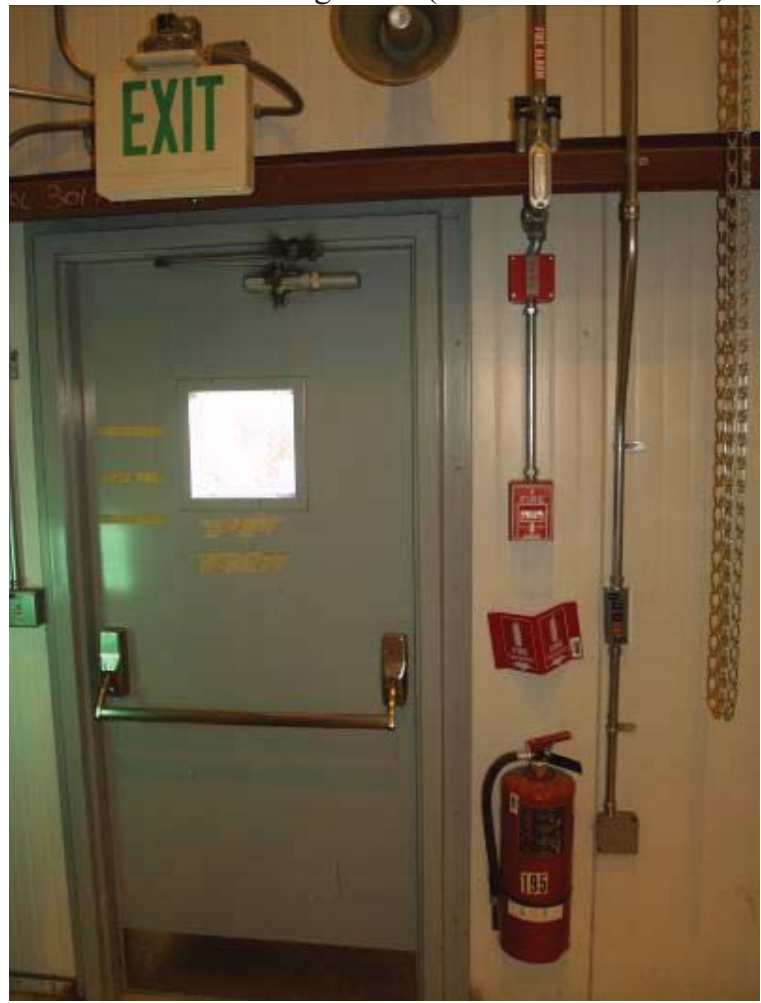

P1015324
Mezzanine View - Equipment Laydown Area

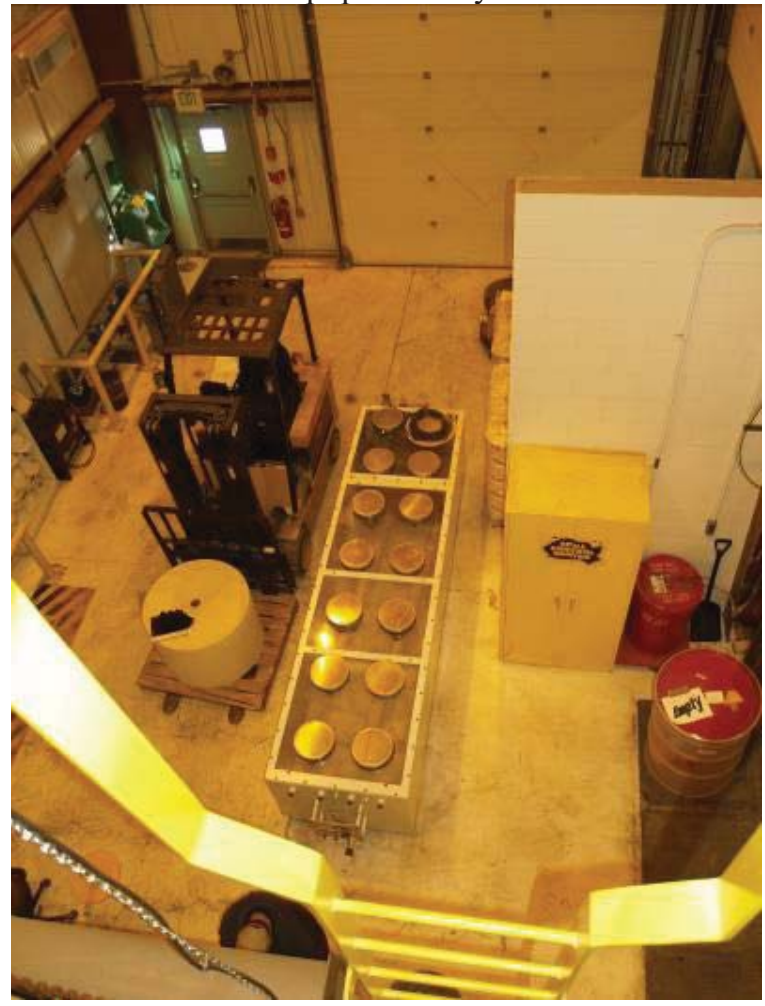


P1015325

Mezzanine View - Equipment Laydown Area

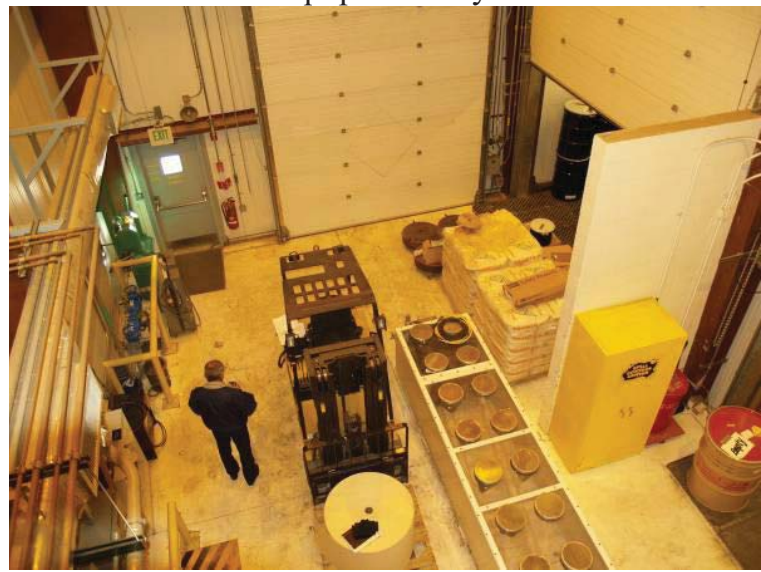

P1015326

Mezzanine View - Equipment Laydown Area (west wall)

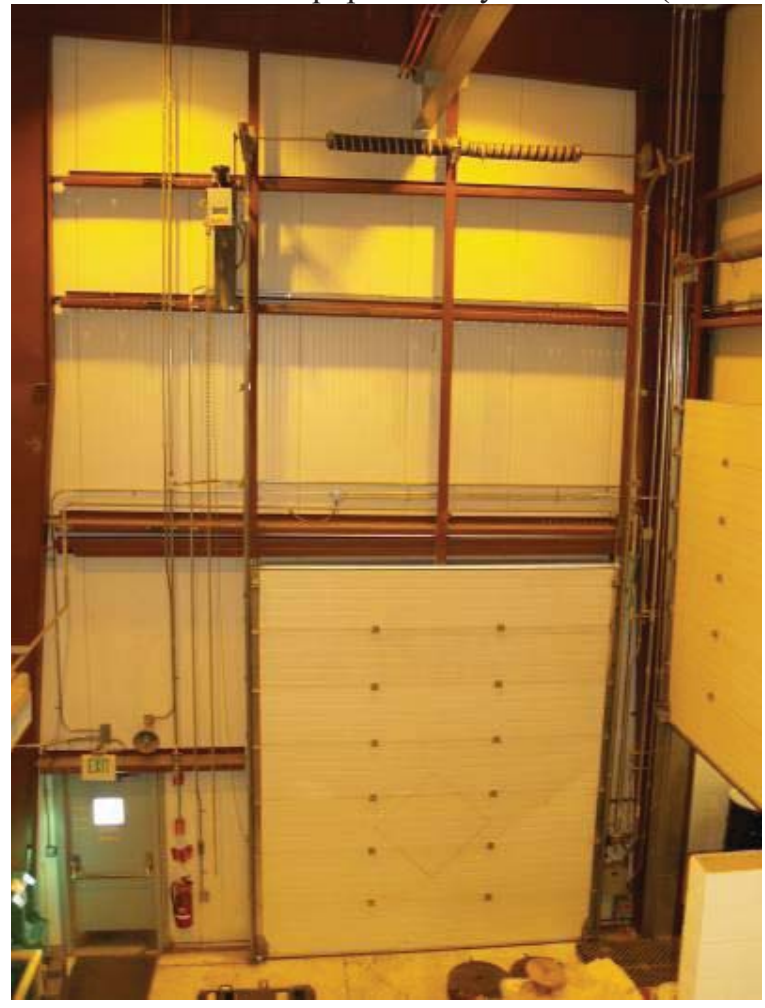


Mezzanine View - Equipment Laydown Area (south wall)

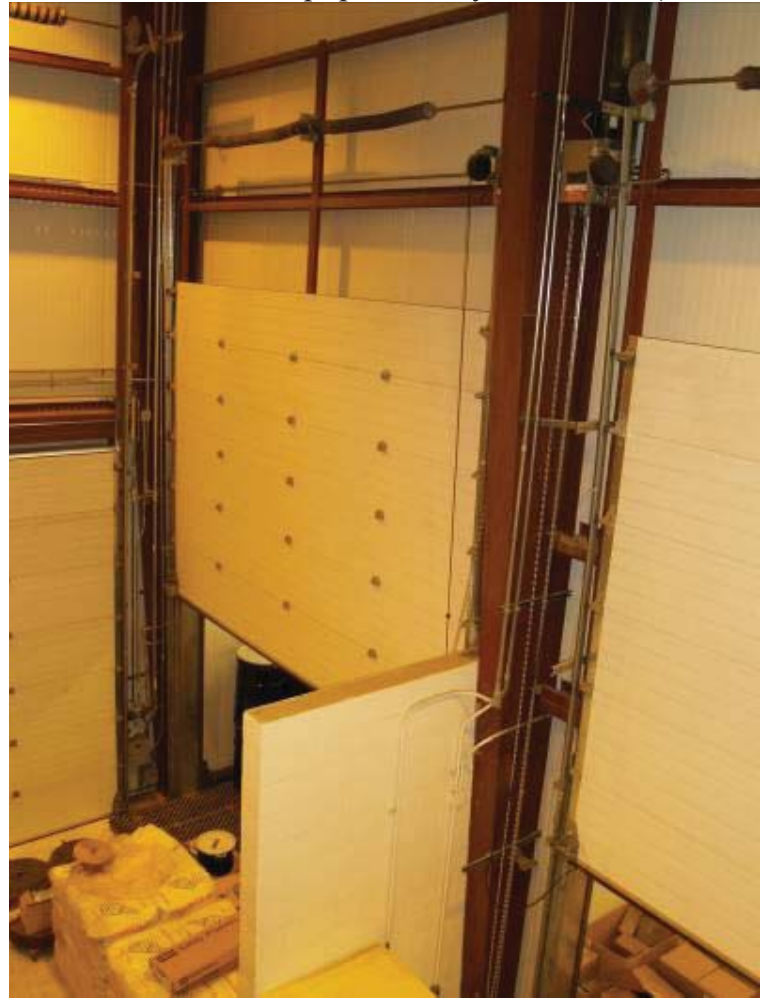

P1015328

Mezzanine View - Equipment Laydown Area (south wall)

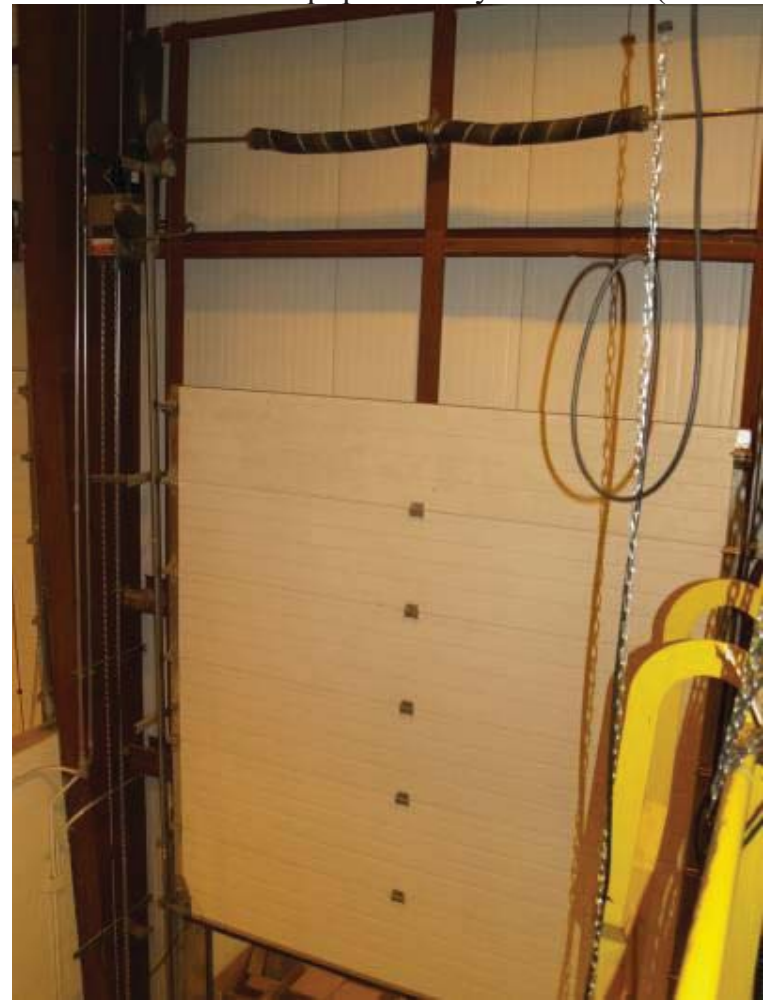


Sodium Processing Facility MFC-799 - Carbonate Sodium Processing Facility

P1015279

Mezzanine/TRANE Unit/2 to 5-Ton Rail Crane (looking south)

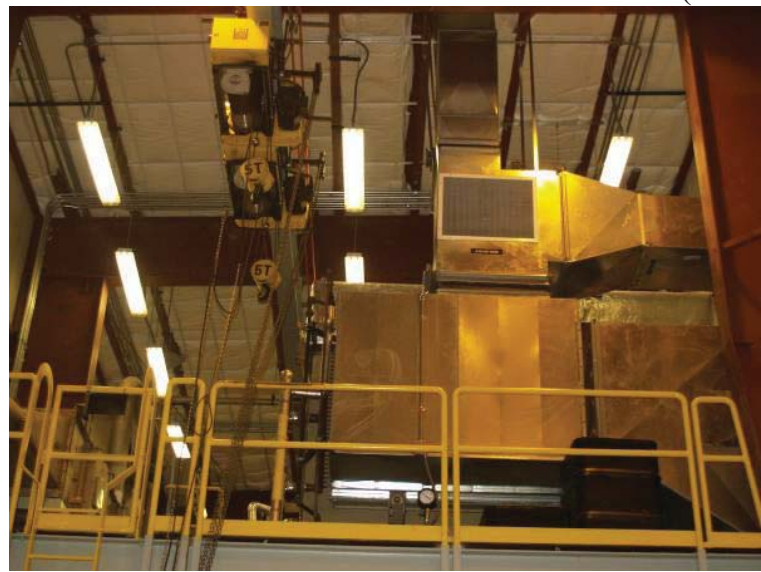

P1015280 Overhead Door \#1 (west side Drum Filling Room)

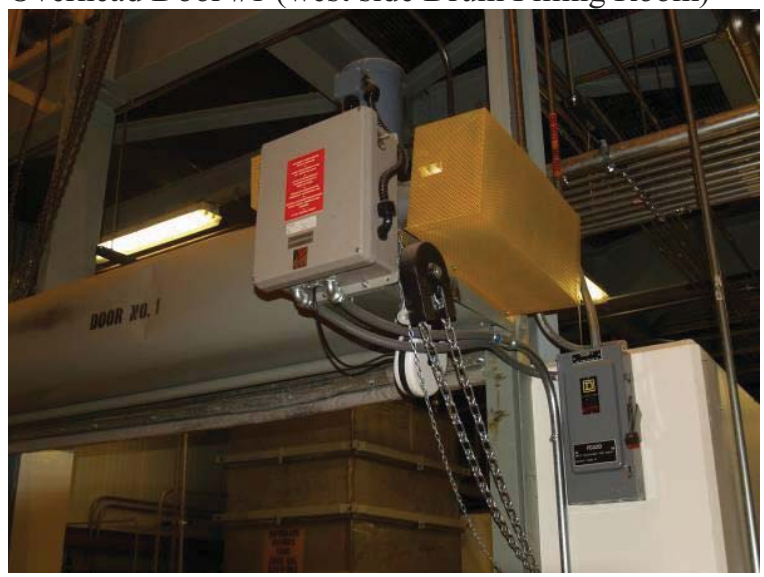


P1015281

Leaded Window looking into Drum Filling Area/Palletizer Control Station

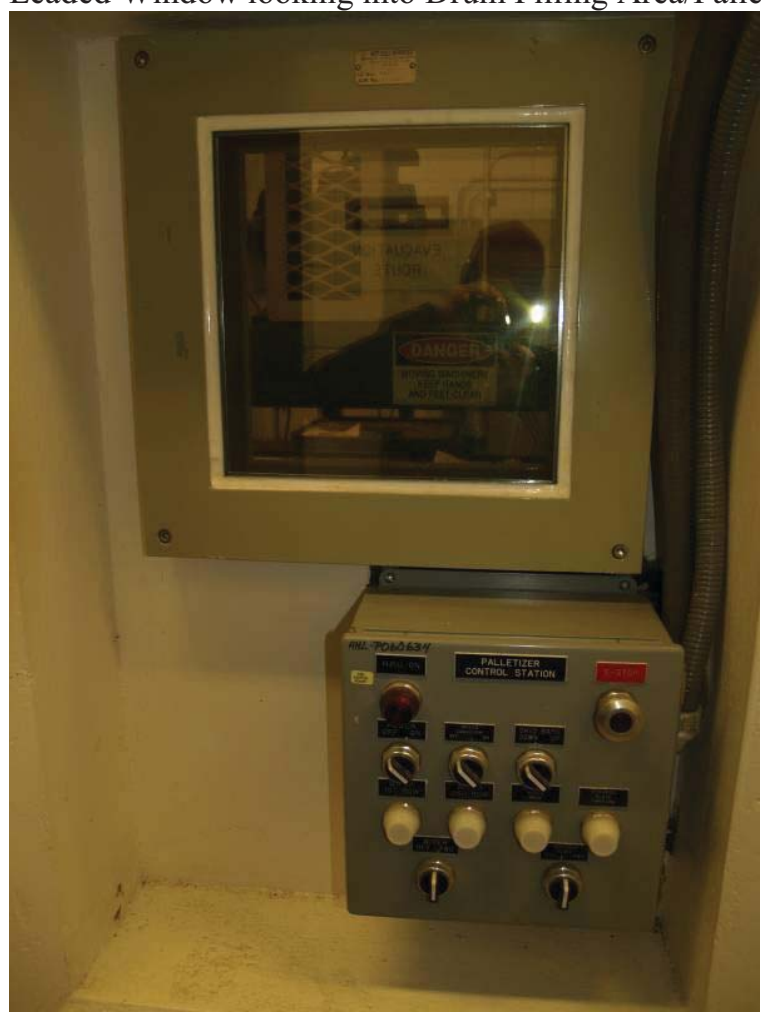

P1015282

Stairway to Mezzanine (looking east)/Main MCC's for Drum Filling Area

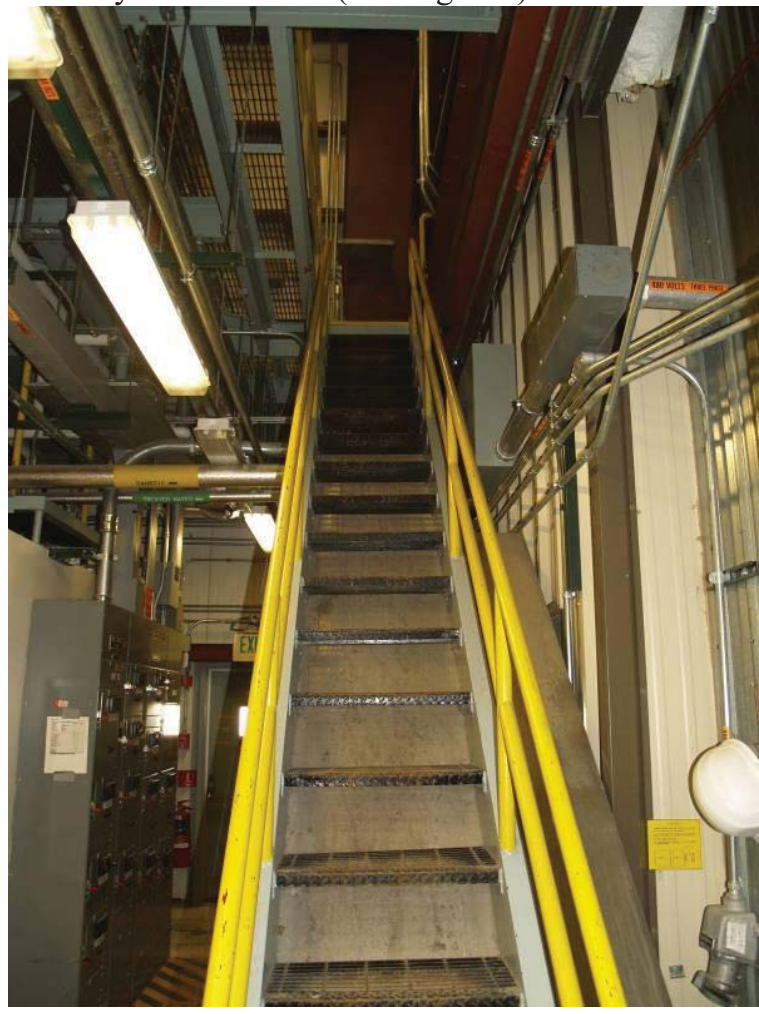




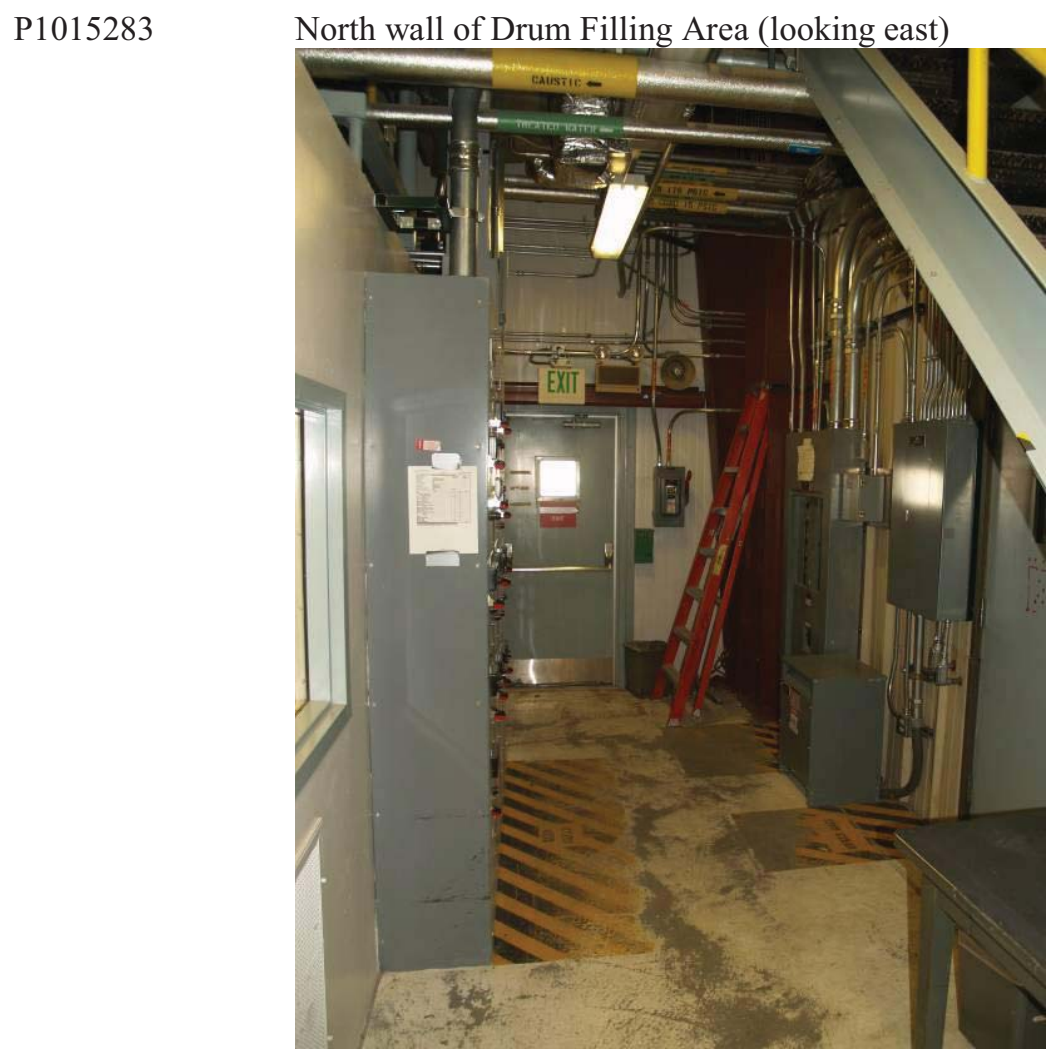

P1015284

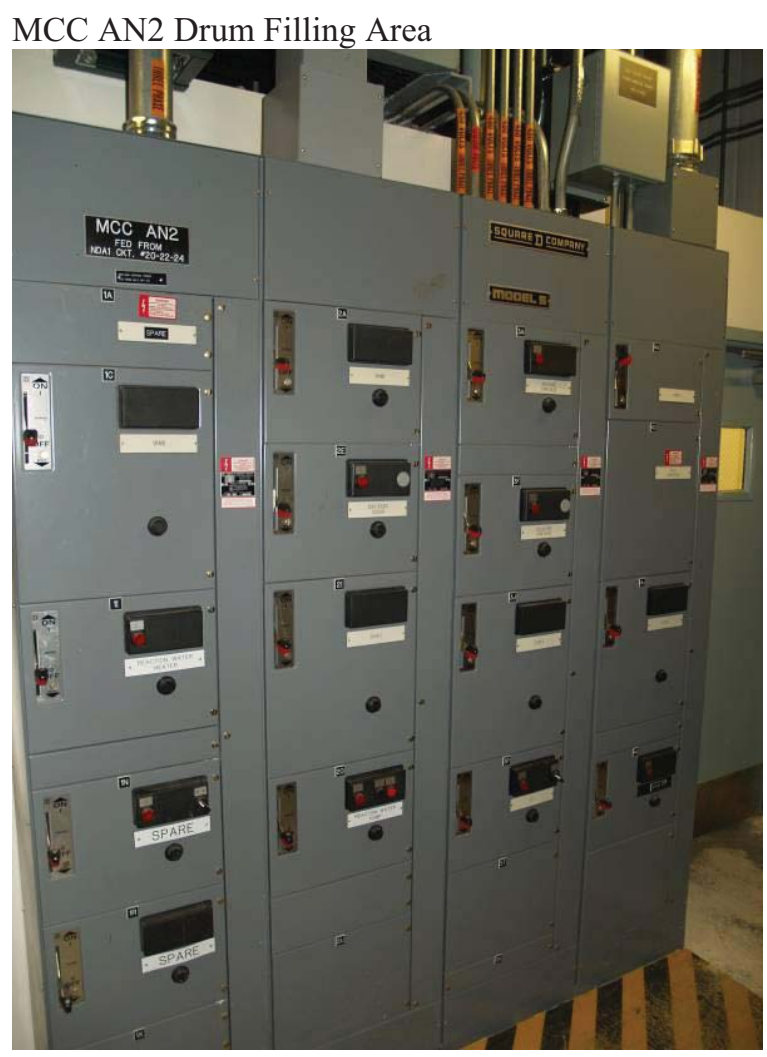


P1015285

NDA1 Power Panel (north wall Drum Filling Area)

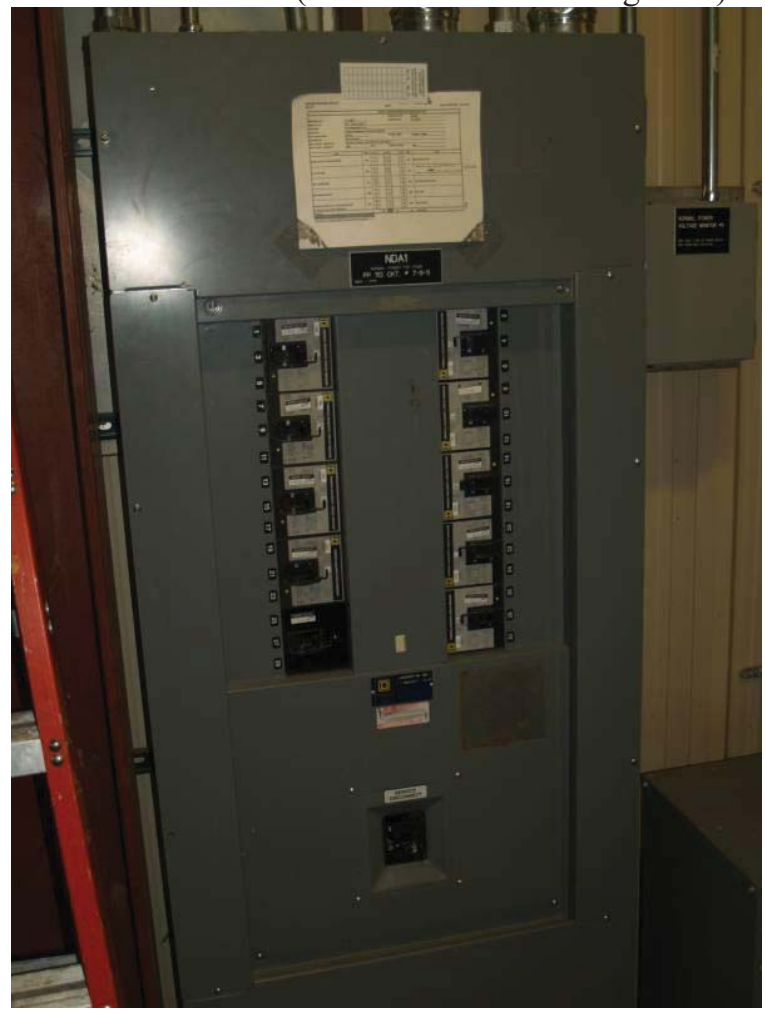

P1015286

Transformer TF 324 - Drum Filling Area

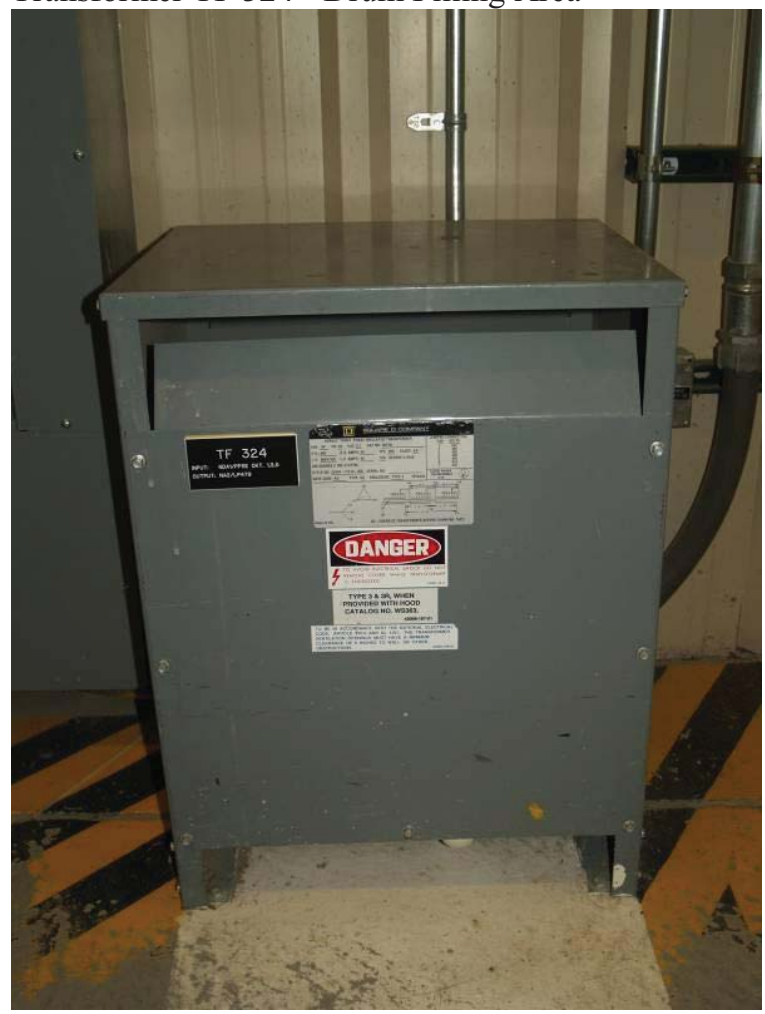




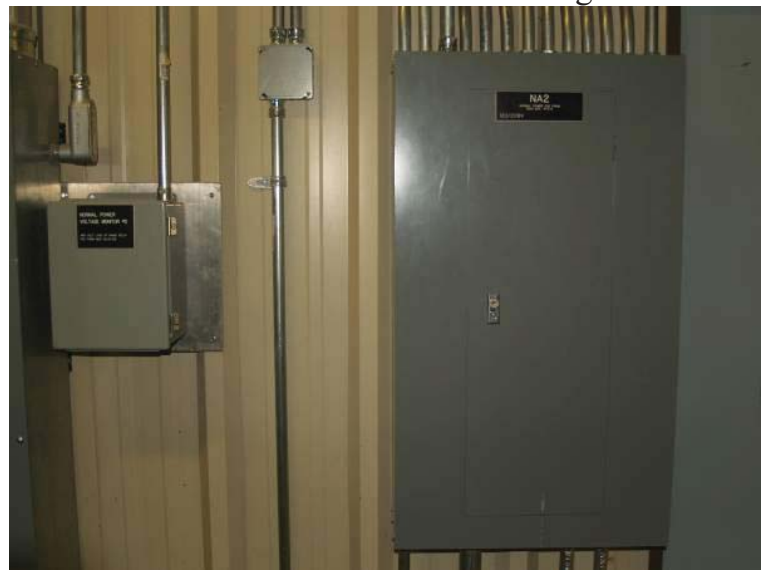

P1015288

Bulk Solids Cooler Power Monitor Cabinet A30-JT-1002 - Drum Filling Area

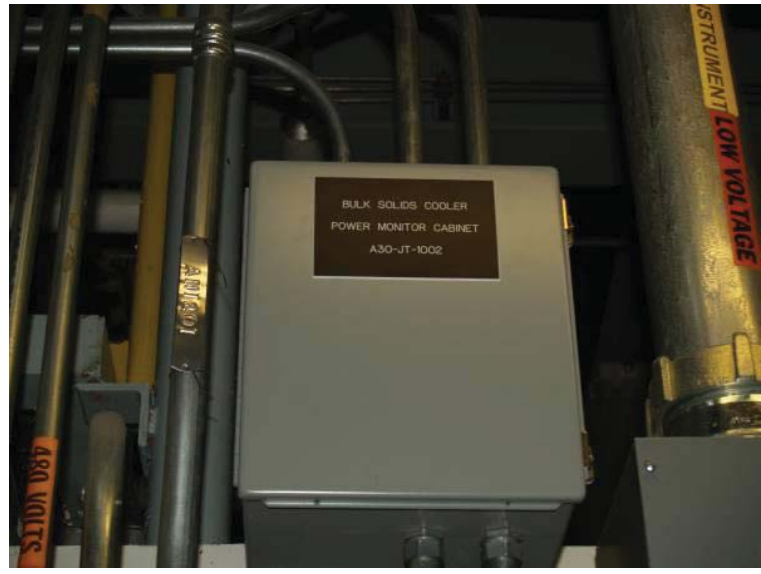

P1015289 480 and 120 Volt Leads into MCC AN2

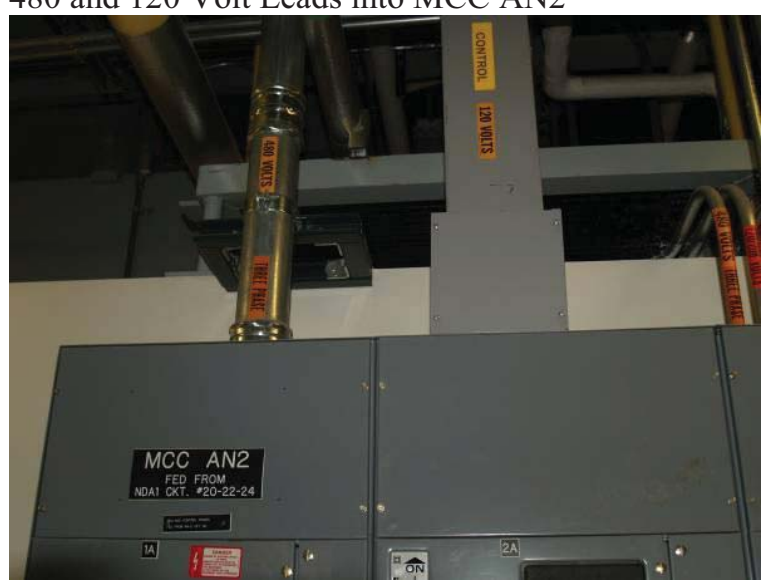


P1015290

480 and 120 Feeds/INC Low Voltage Feeds

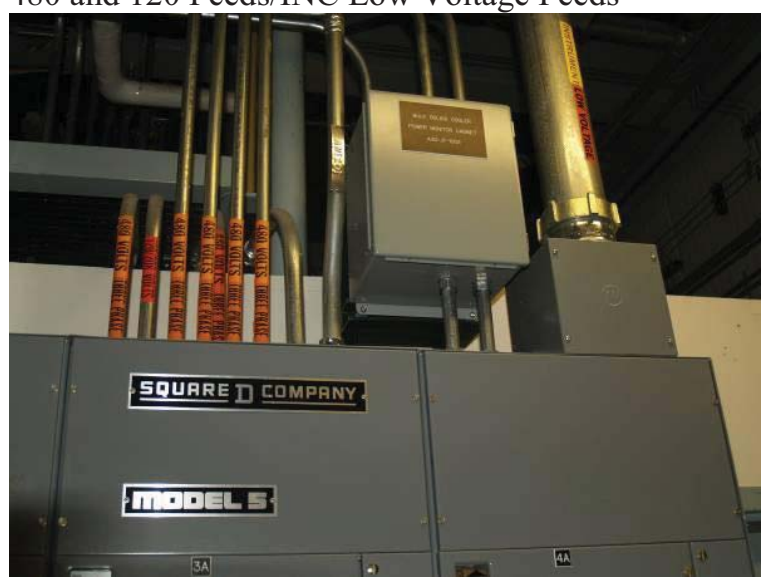

P1015291

Drum Staging Area (looking south)

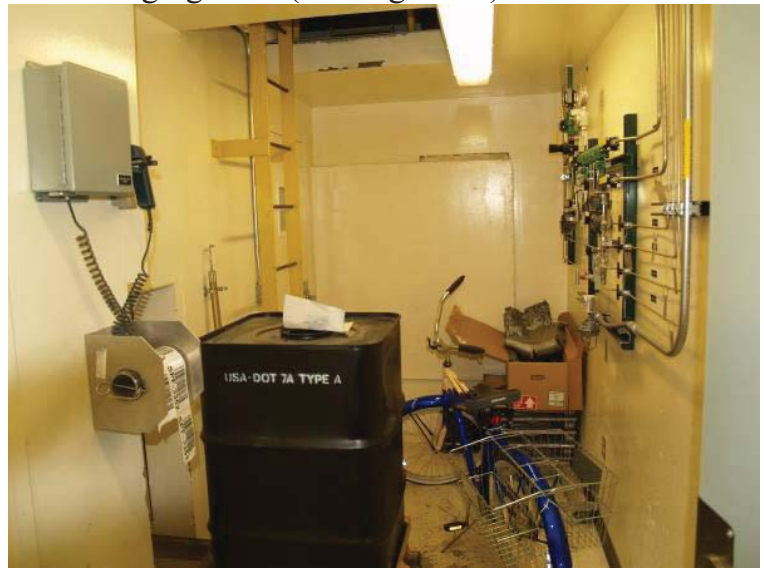


P1015292

Control Panel Control Box for Drum Filling Room (looking west)

P1015293

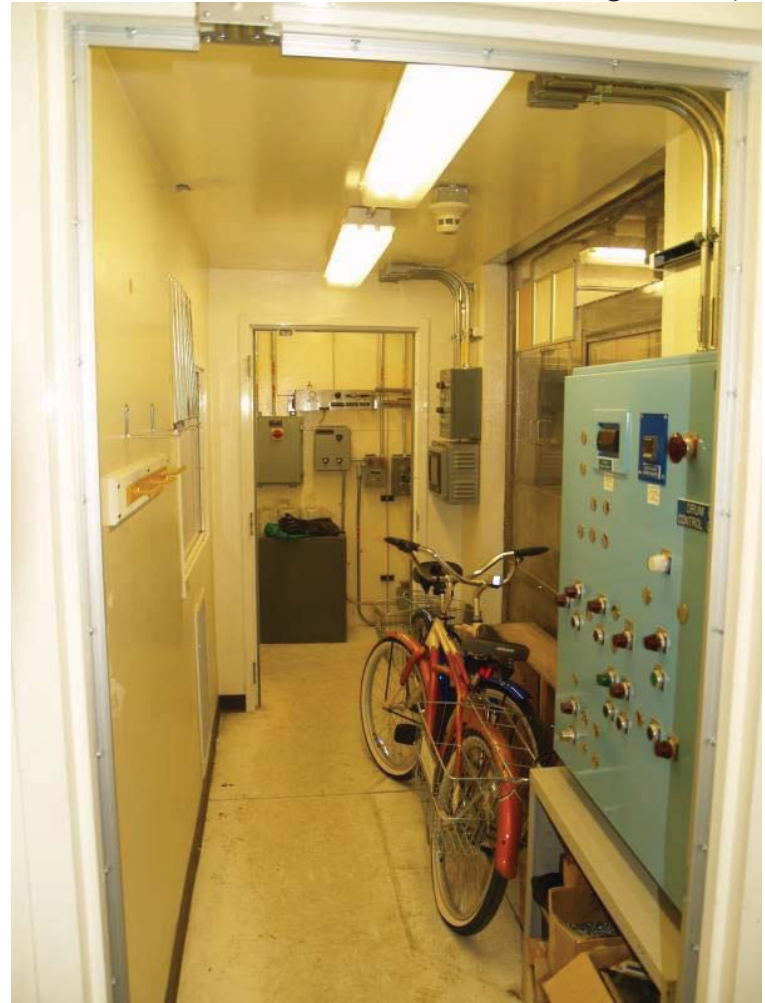

Drum Fill Control Cabinet

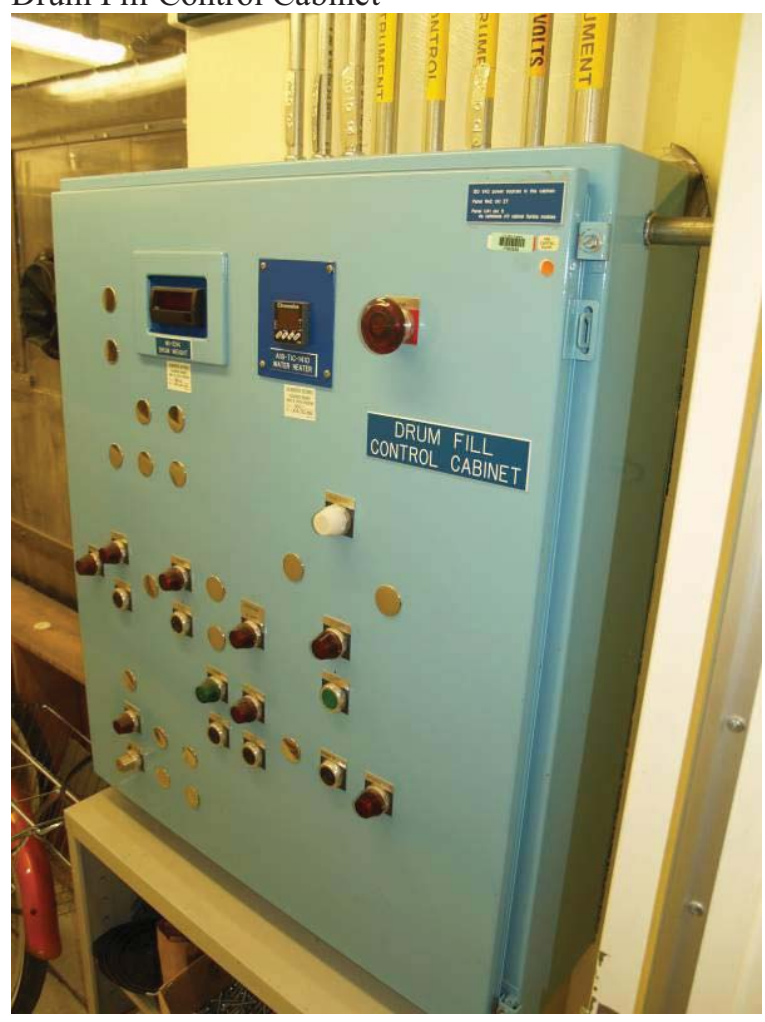


P1015294

Glovebox - Drum Fill Room

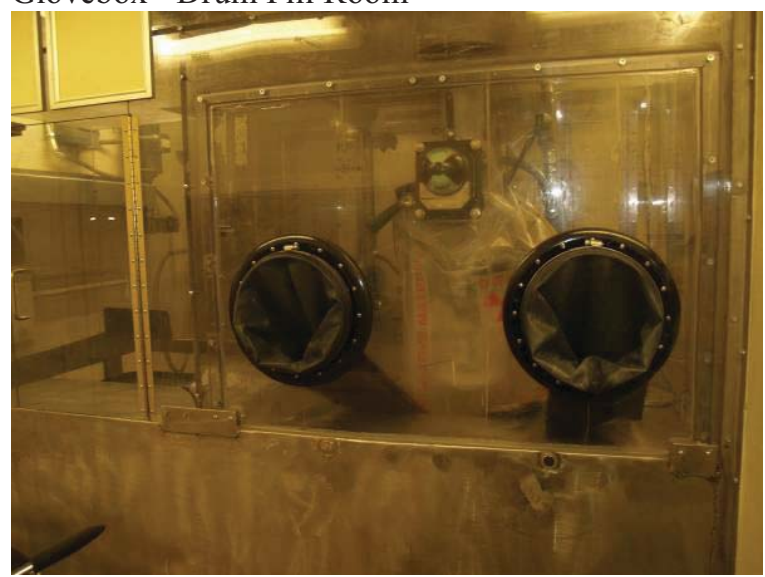

P1015295

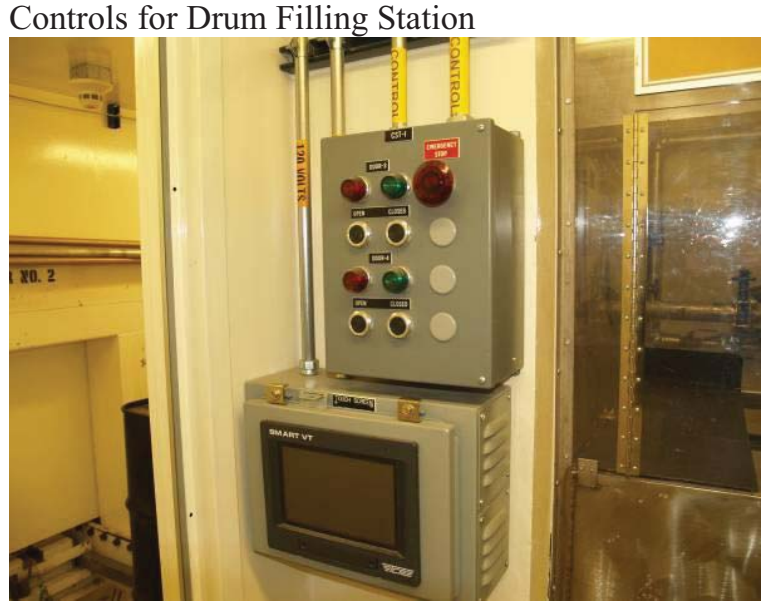

P1015296
Through Glovebox into Drum Fill Room (looking south)

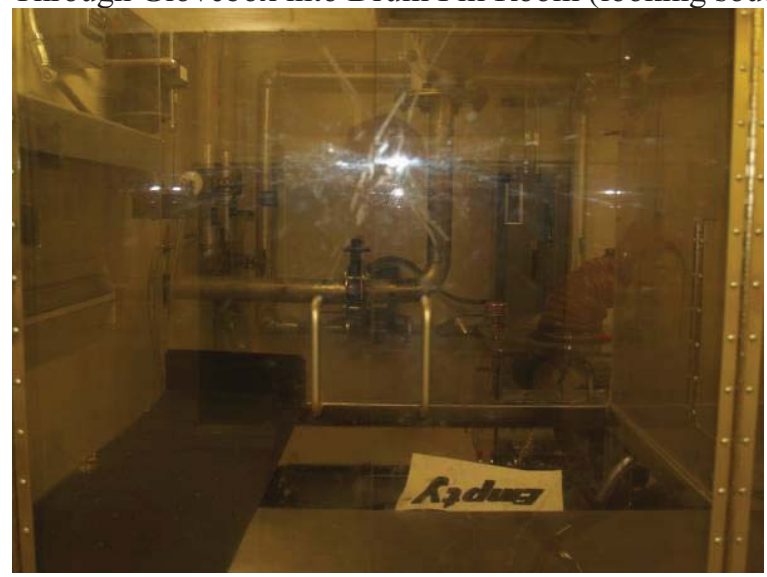


P1015297

P1015298
Control Panels for Drum Transfer Trolley

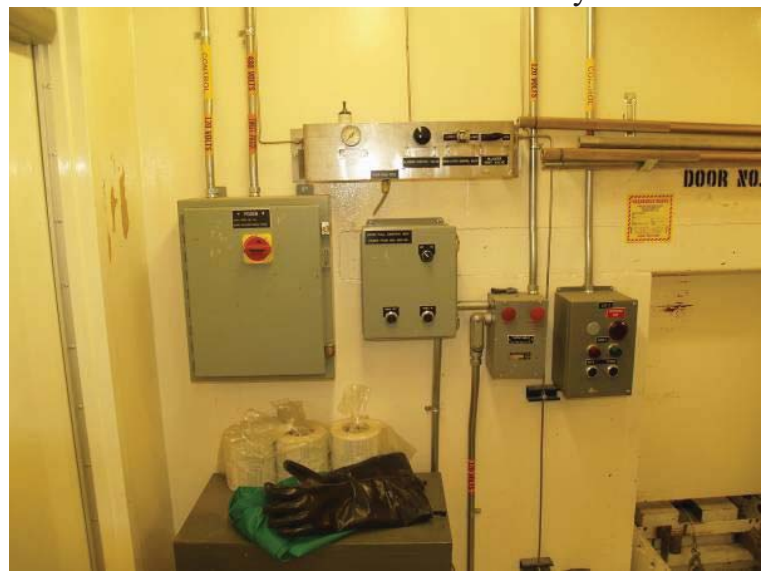

Drum Transfer Trolley Weigh Station

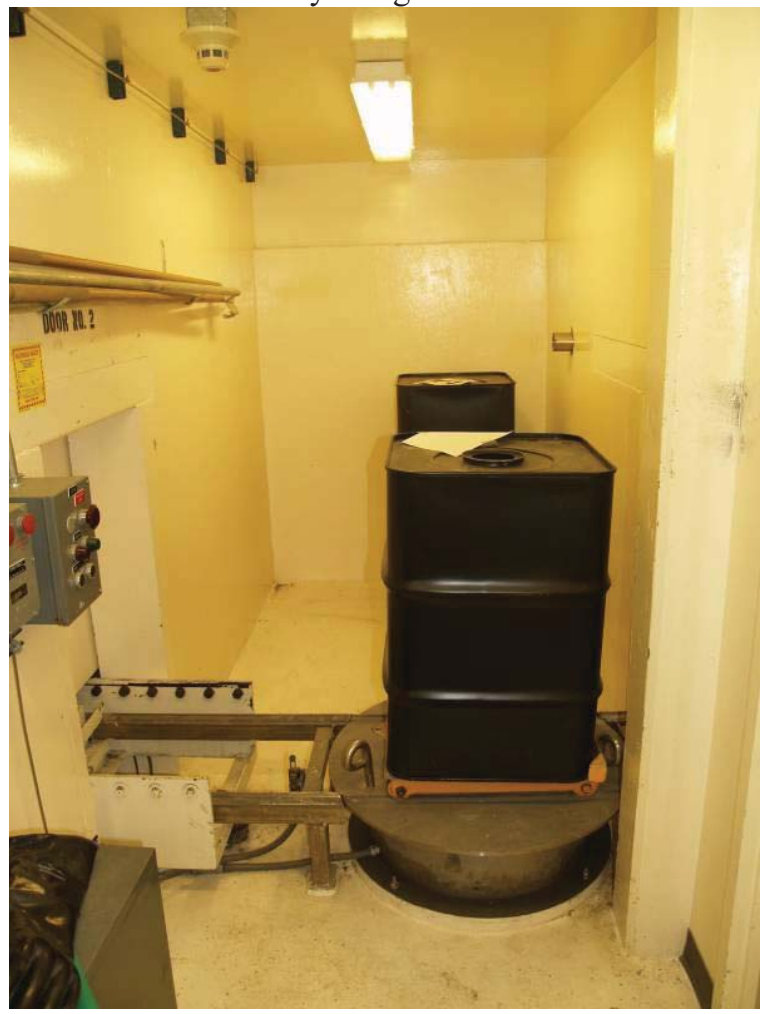


P1015299

P1015300
Through Man Door into Drum Fill Room (looking west)

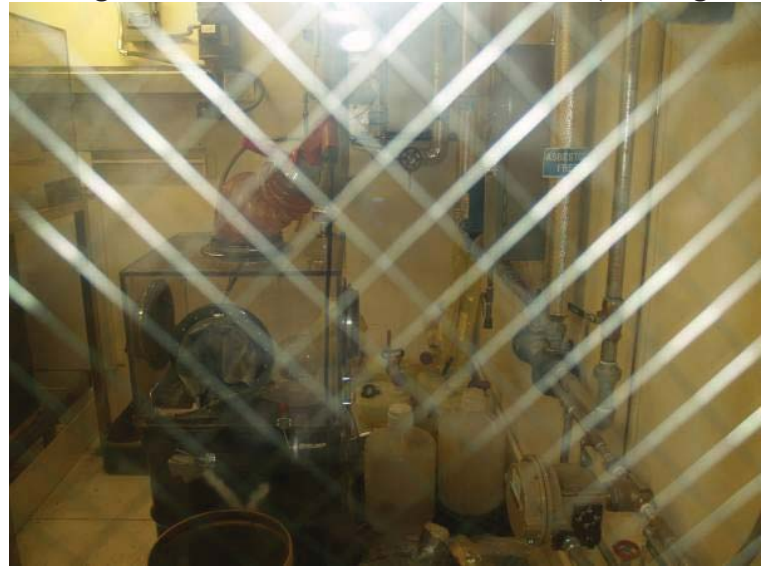

Drum Fill Room (looking northwest)

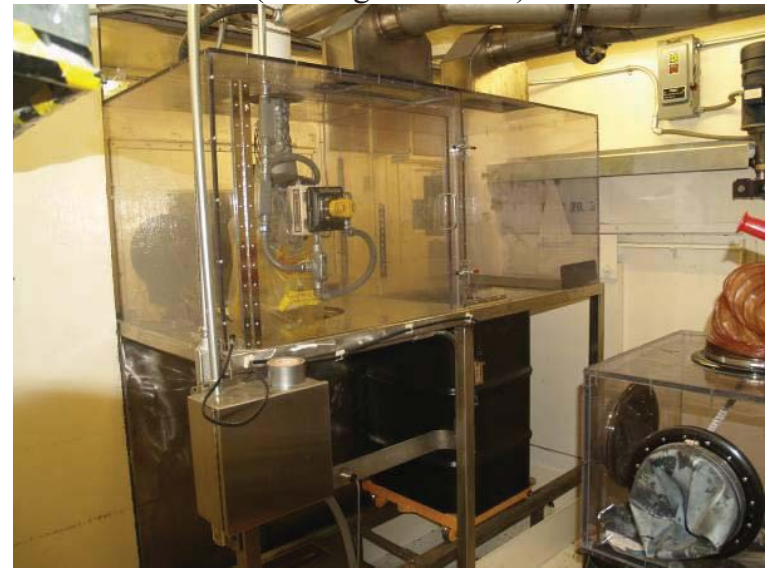


P1015301

Drum Fill Room, Miscellaneous Materials, Waste (looking east)

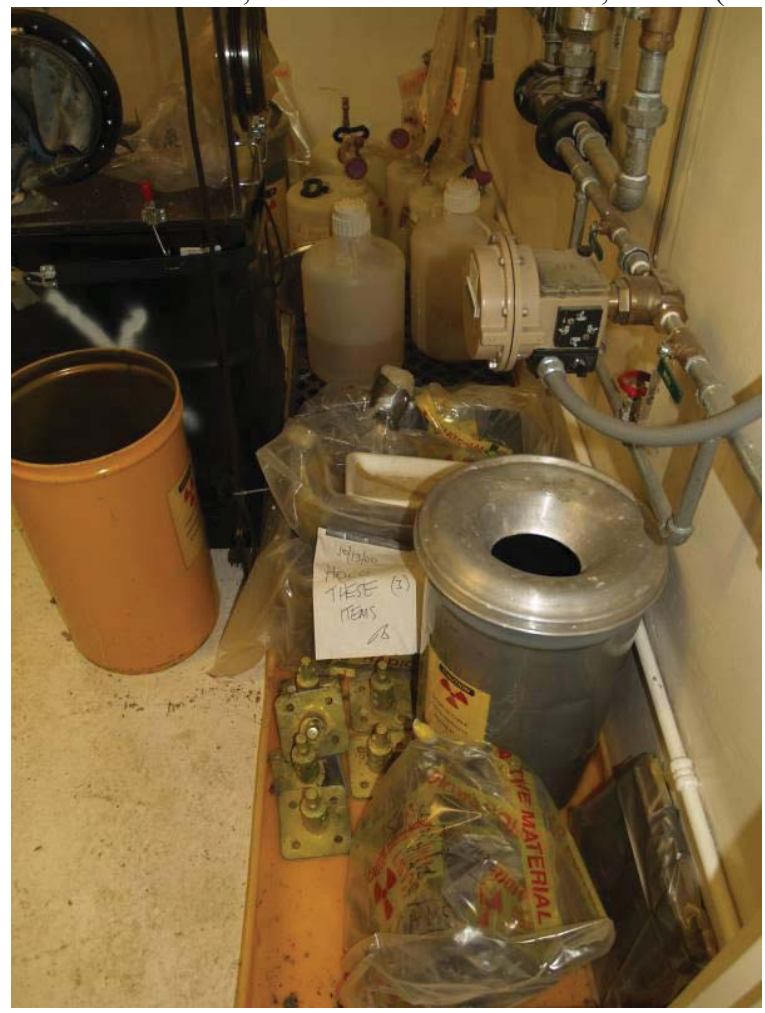

P1015302

Portable Drum Glovebox

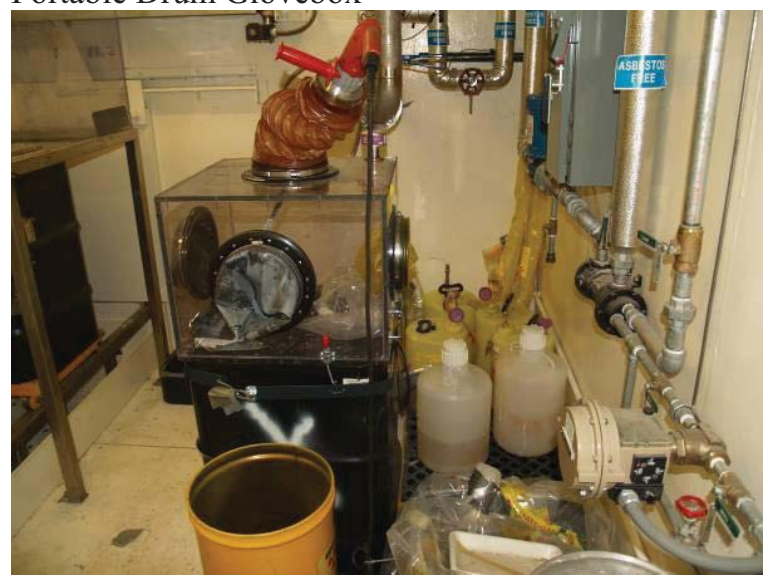


P1015303

Glovebox Off-gas Ducting

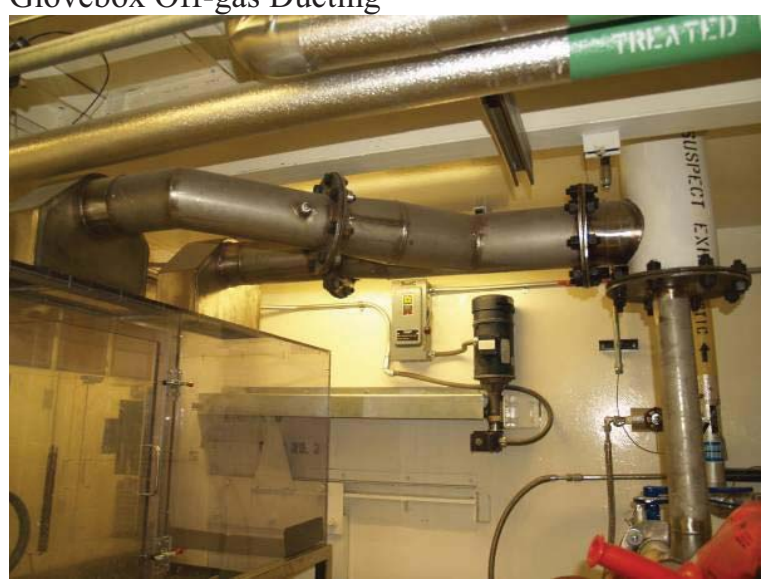

P1015304

Door Disconnect Switch (Door 4)

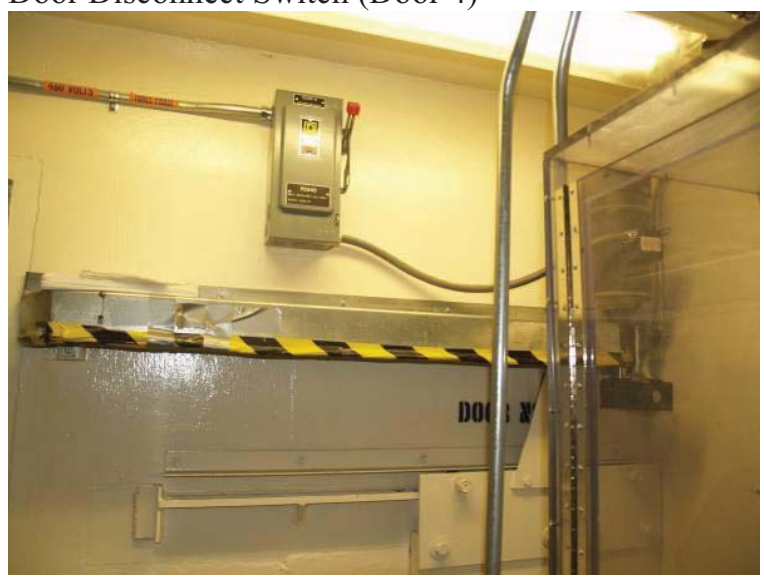

P1015305

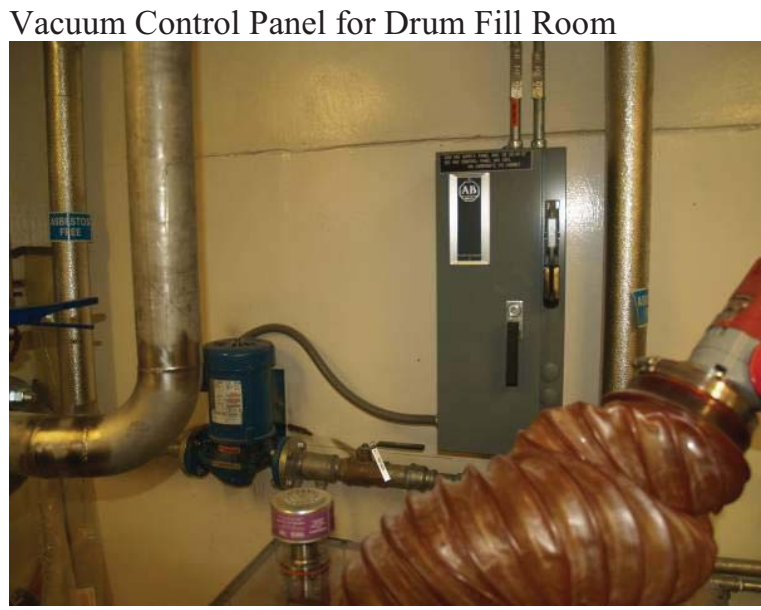


P1015306

Door Disconnect Switch (Door 3)

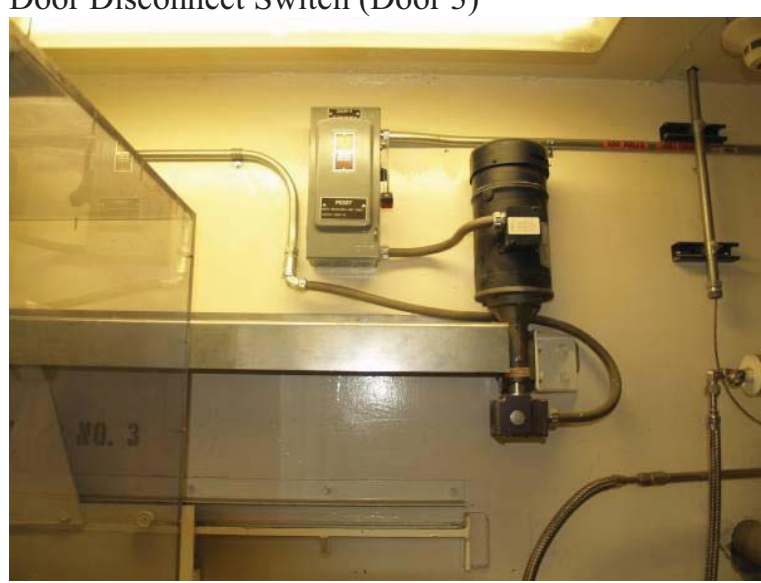

P1015307

P1015308
Caustic Line Feeds into Drum Fill Room

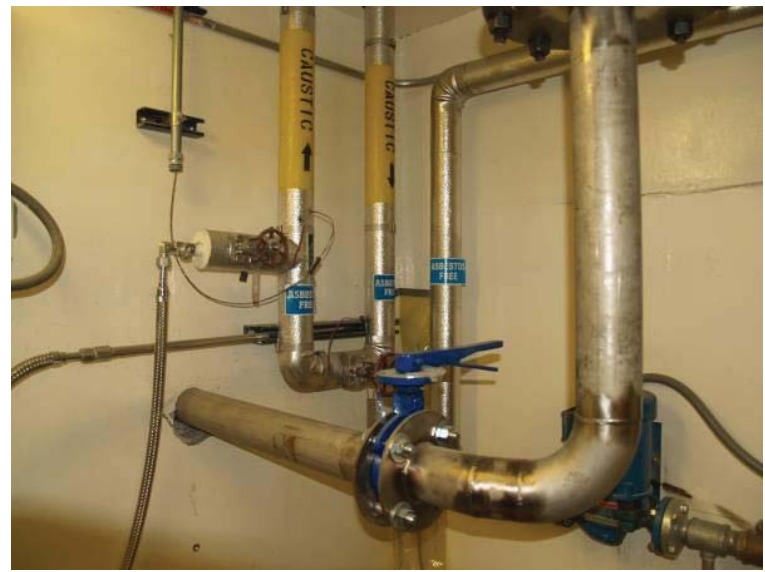

Portable Constant Air Monitor (on Mezzanine)

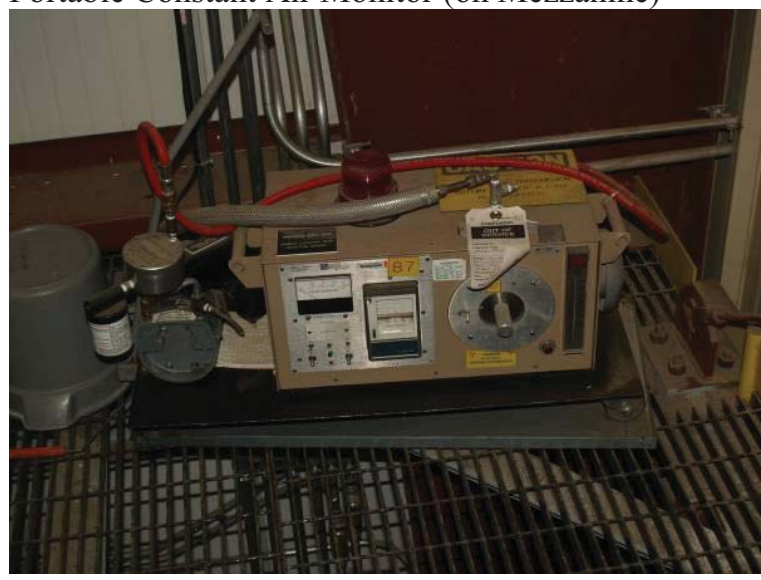


P1015309

Mezzanine Stairway (looking west and down)

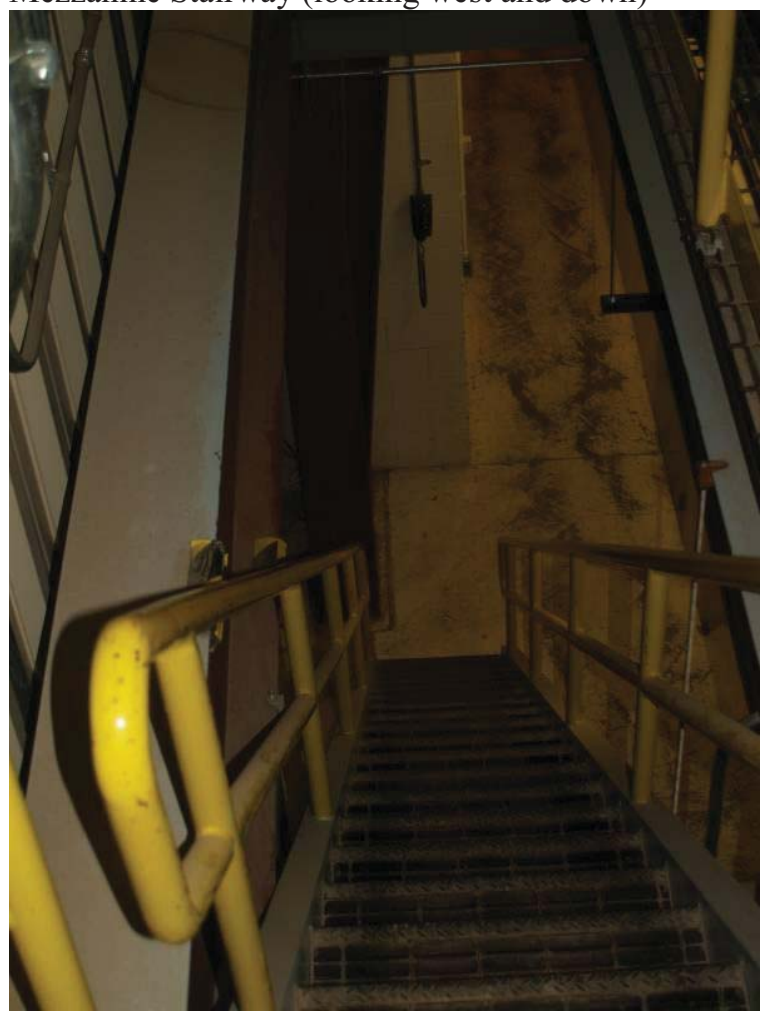

P1015310

$\mathrm{CO} 2$ Piping on Mezzanine (associated with drum fill)

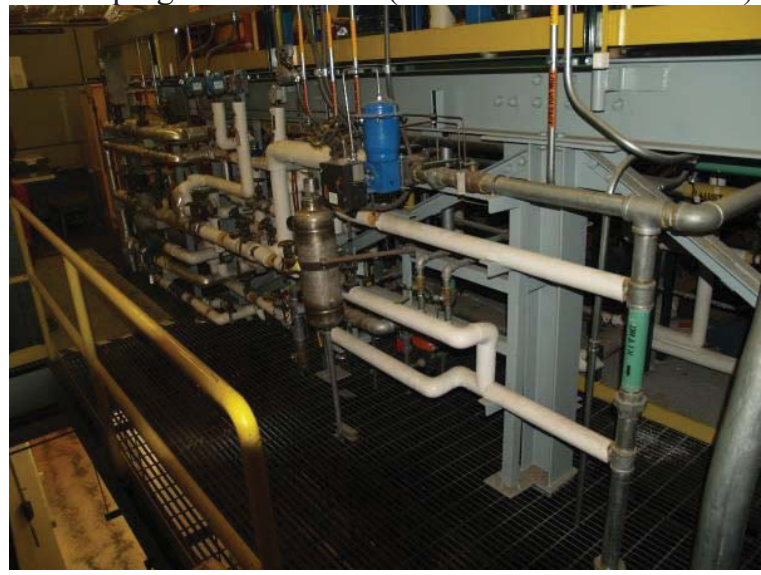


P1015311

Caustic and other Piping under Mezzanine

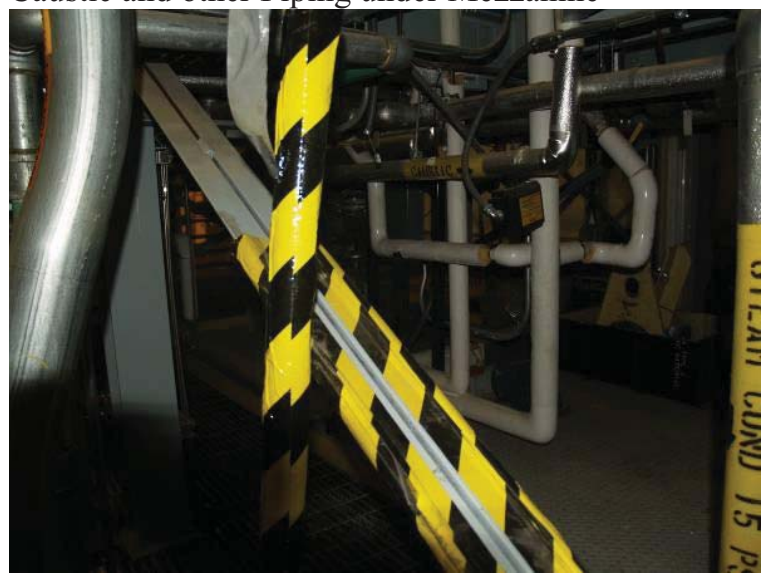

P1015312

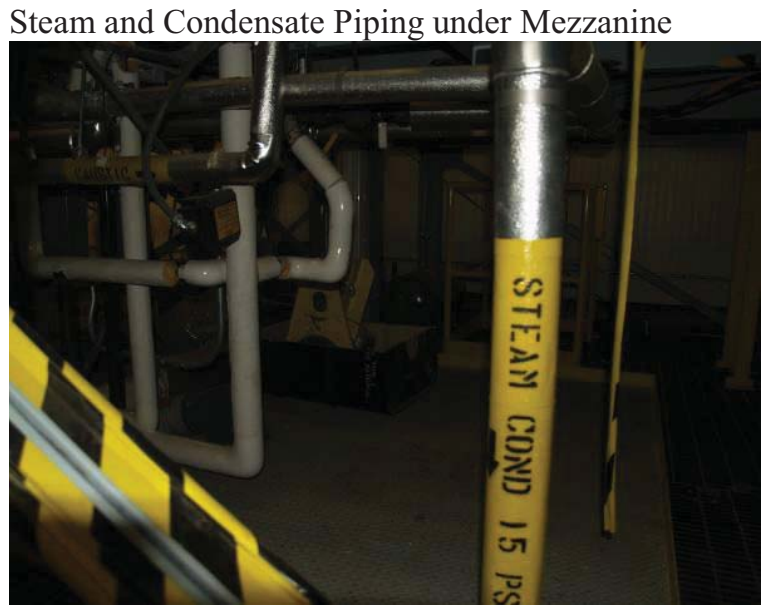

P1015313

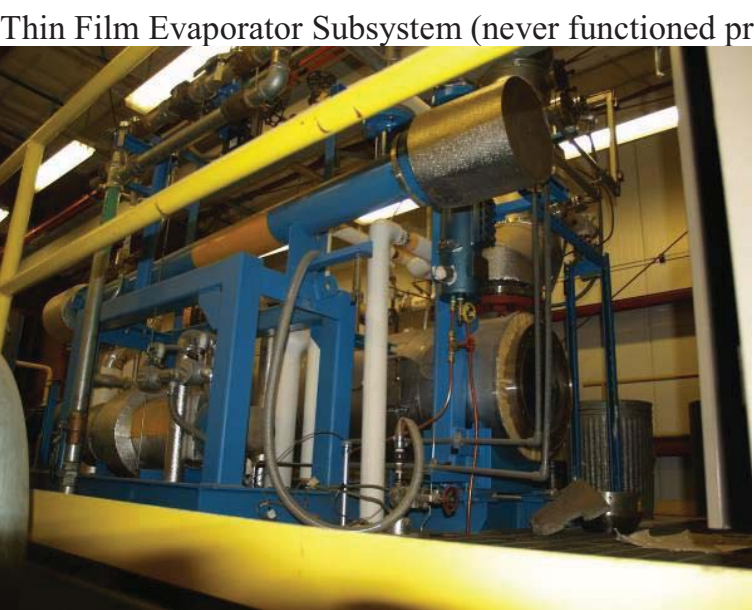


P1015314

RMA Storage Cabinet on Mezzanine

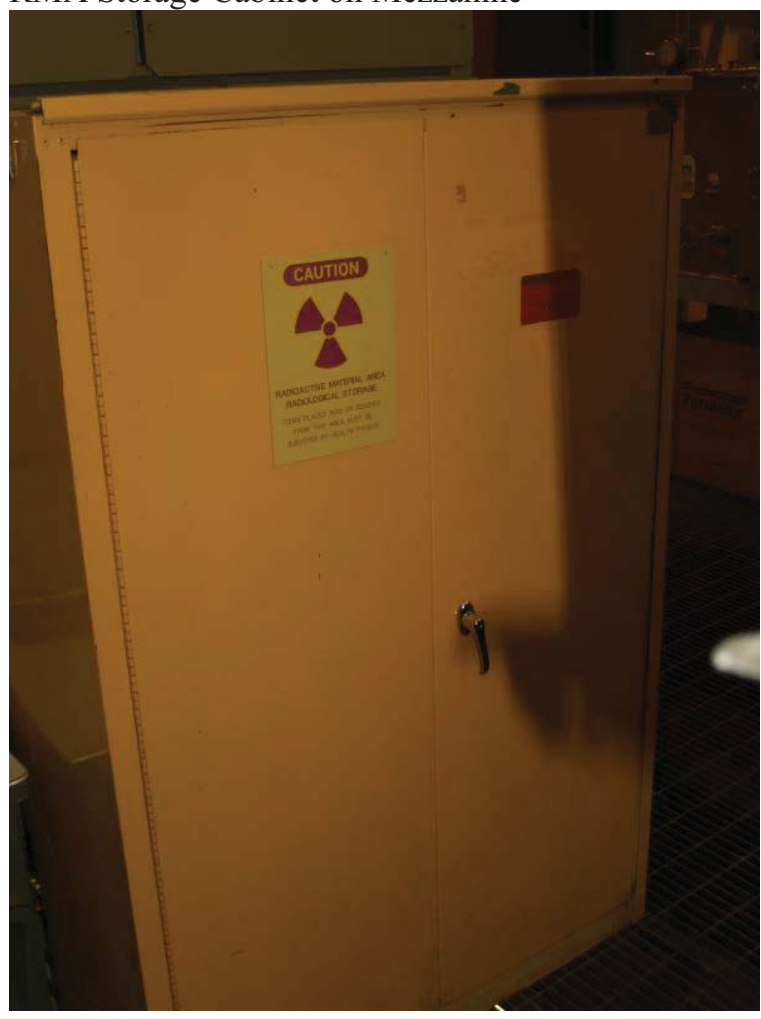

P1015315
TRANE HVAC - Mezzanine (looking west)

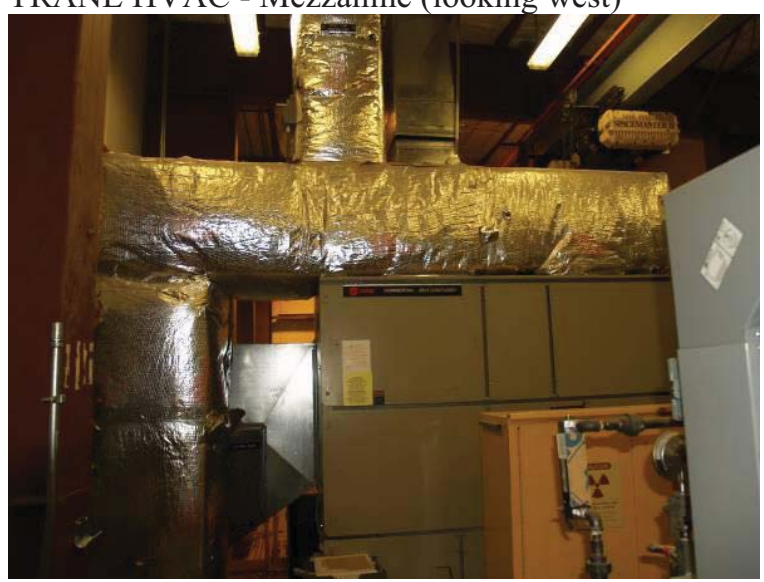


P1015316

HVAC Control Panel A31-AHU-1301 - north wall of Mezzanine

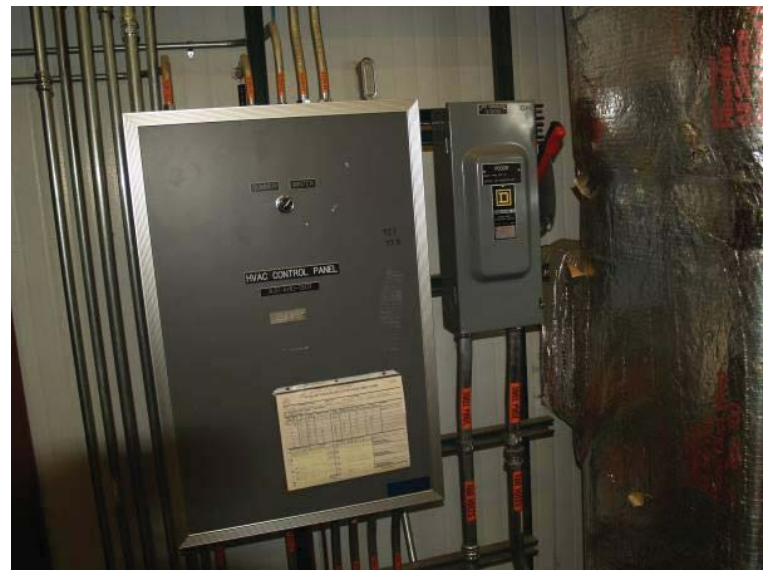

P1015317

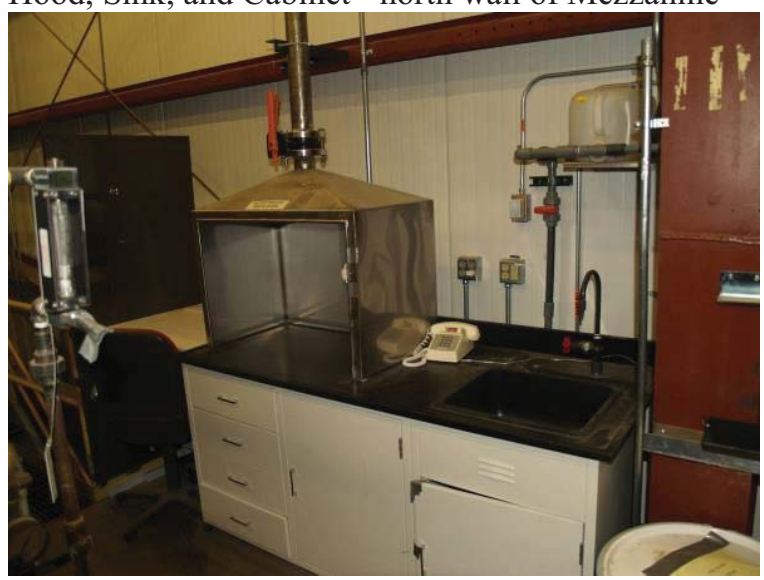

P1015318

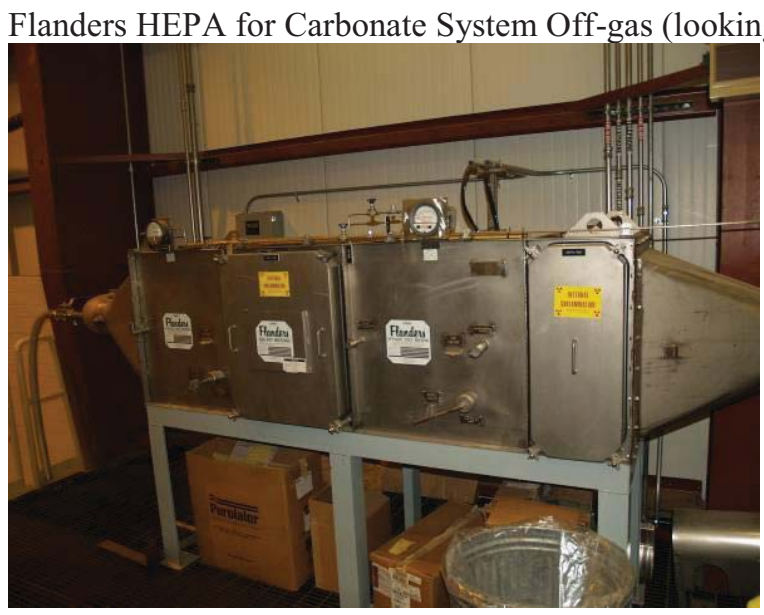


P1015319

Suspect Exhaust Ducting into HEPAs

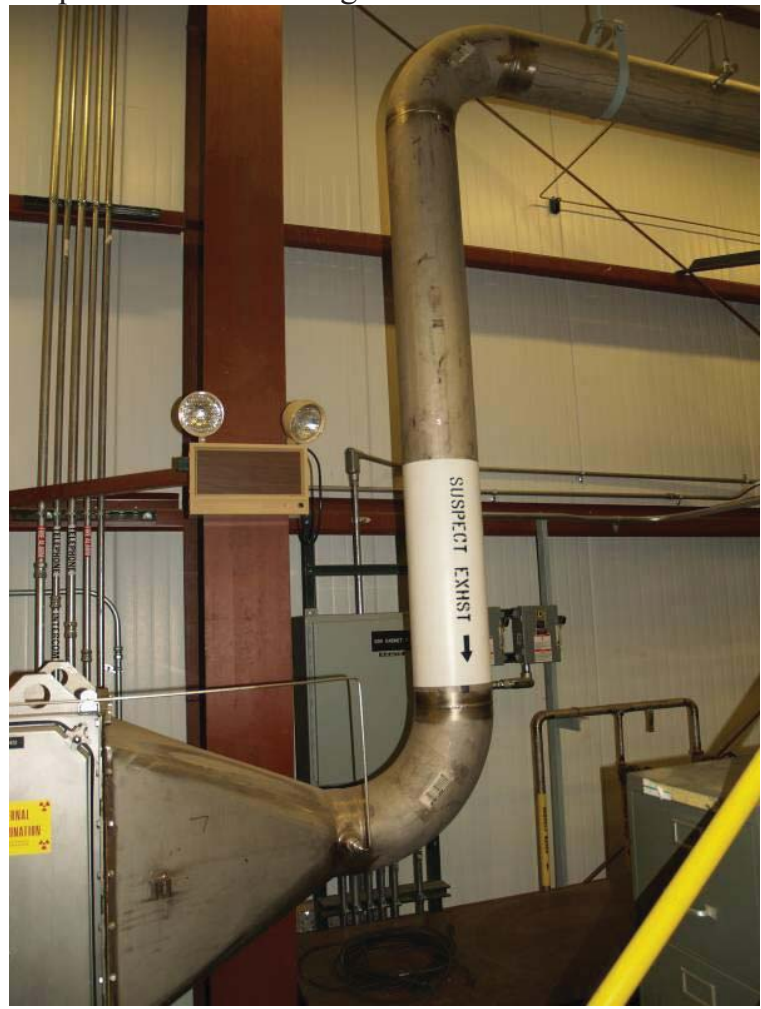

P1015320

Flanders HEPA for Carbonate System Off-gas (looking southeast)

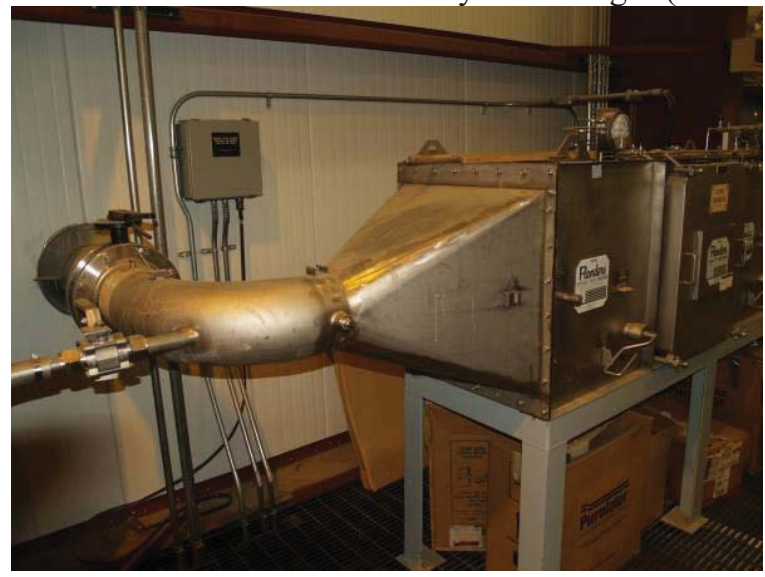


P1015321

HEPA and Ducting (looking east)

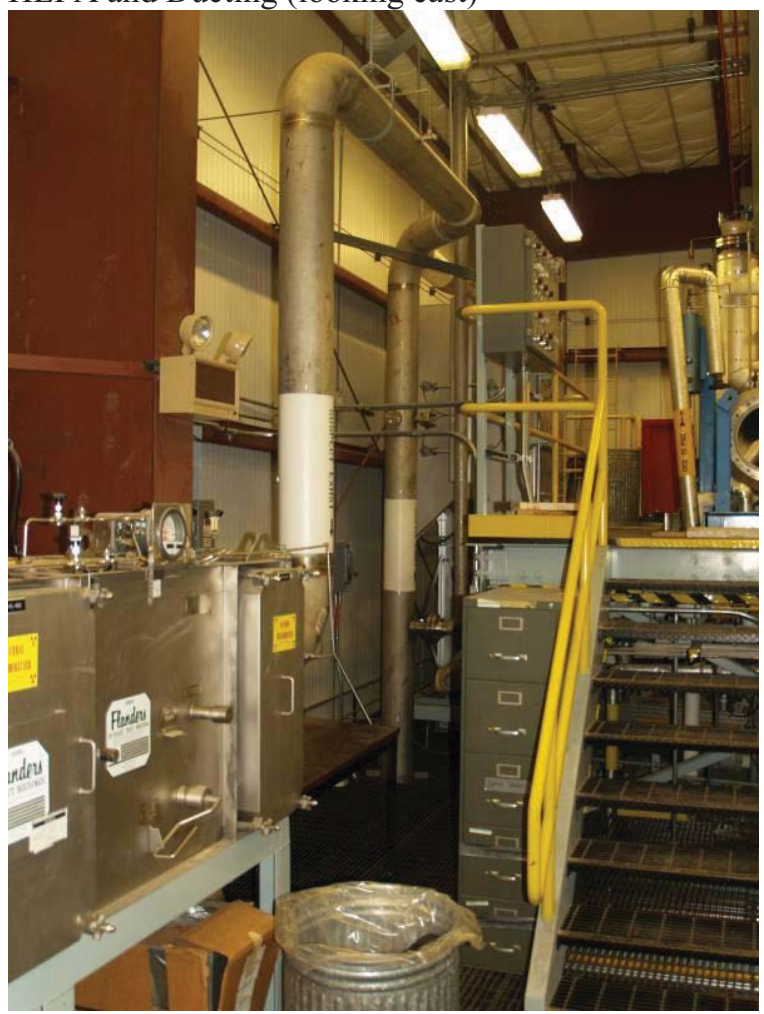

P1015322

Steam and Condensate Return on TRANE Unit (looking north)

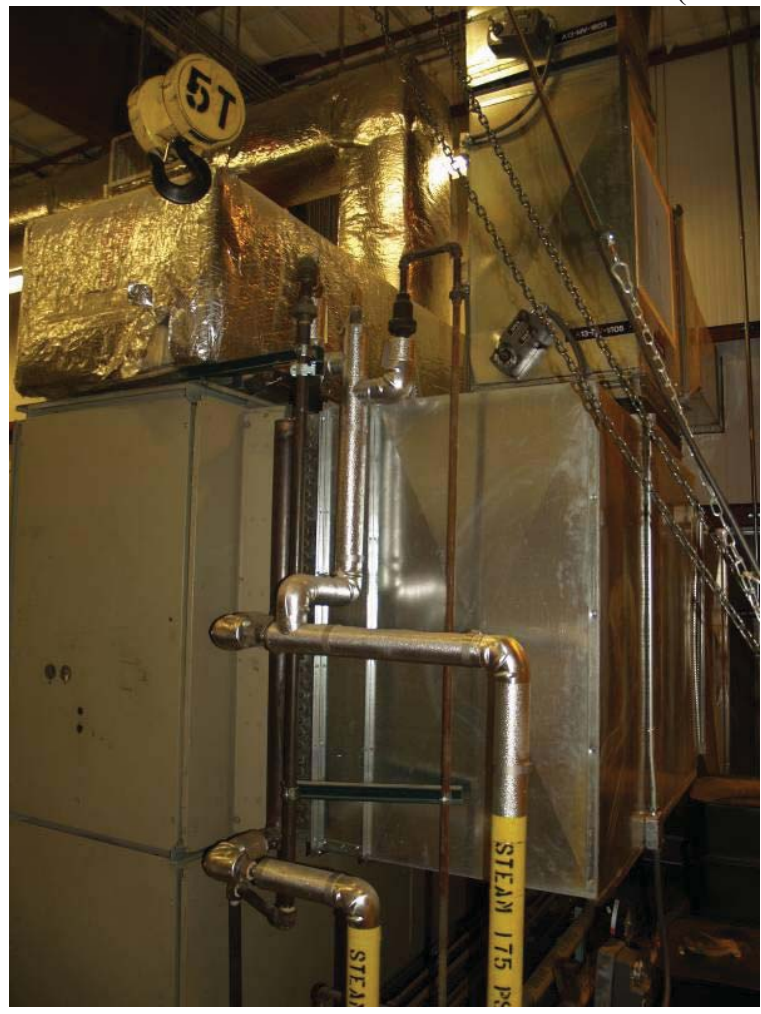


P1015323

Steam and Condensate Return on TRANE Unit (looking north)

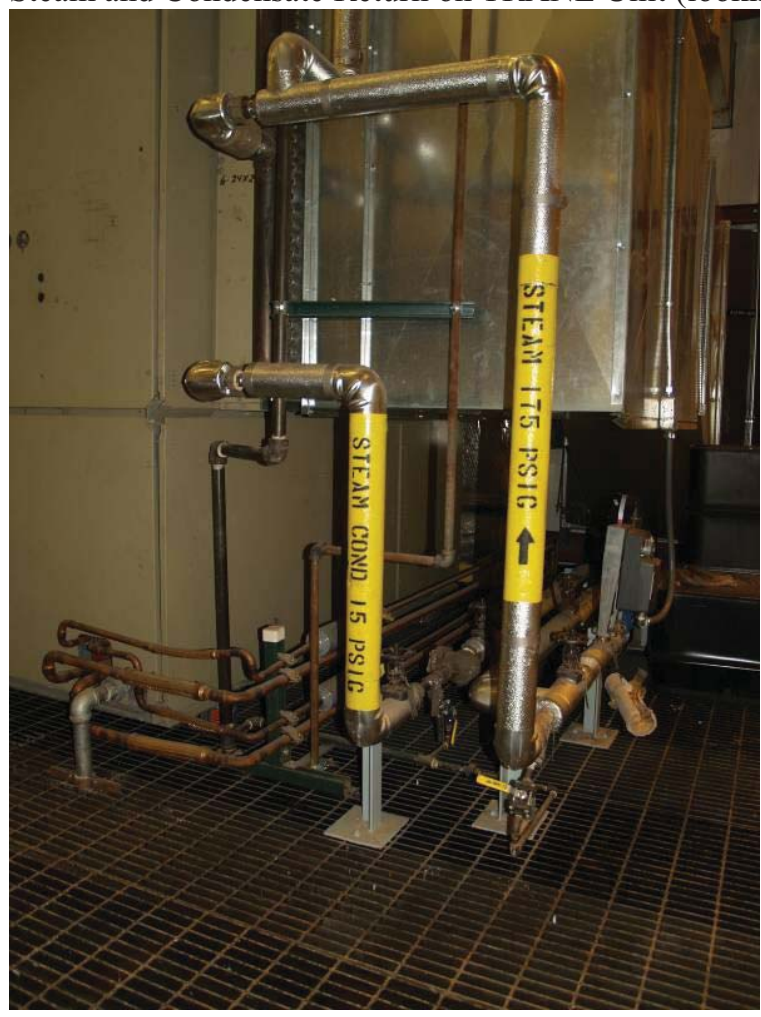

P1015329
CO2 Subsystem - Mezzanine (looking east)

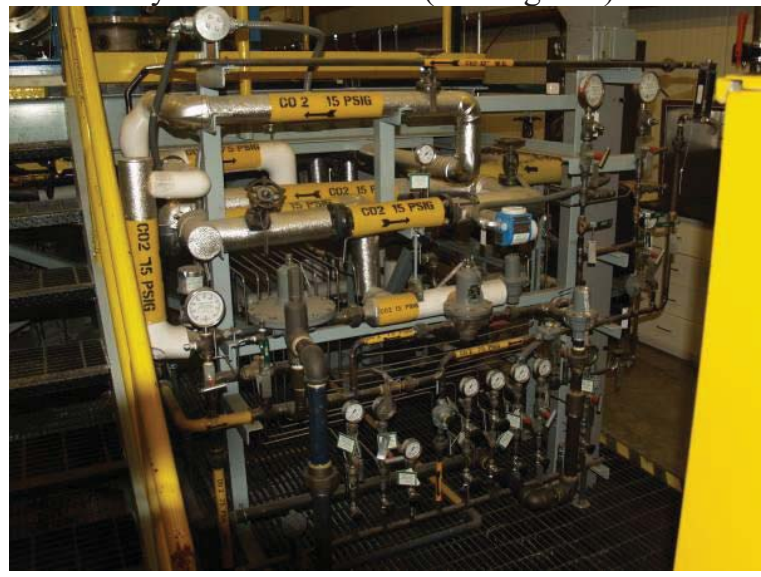


P1015330

Exhaust Piping for Carbonate System - on Mezzanine

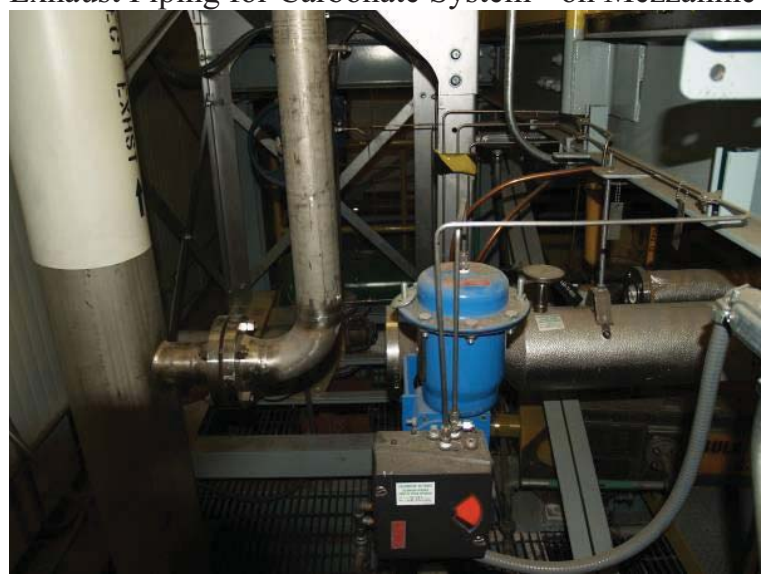

P1015331

Fan for Exhaust Blower

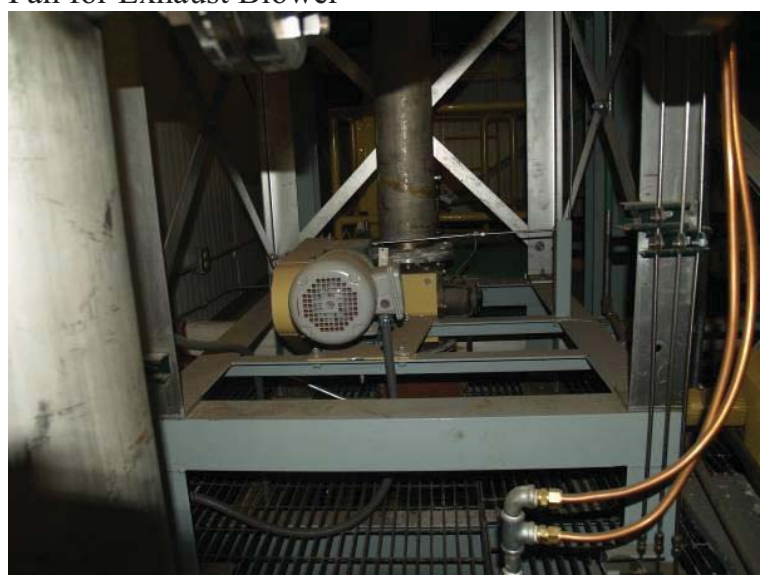

P1015332

Bulk Solids Cooler A30-HX-1001

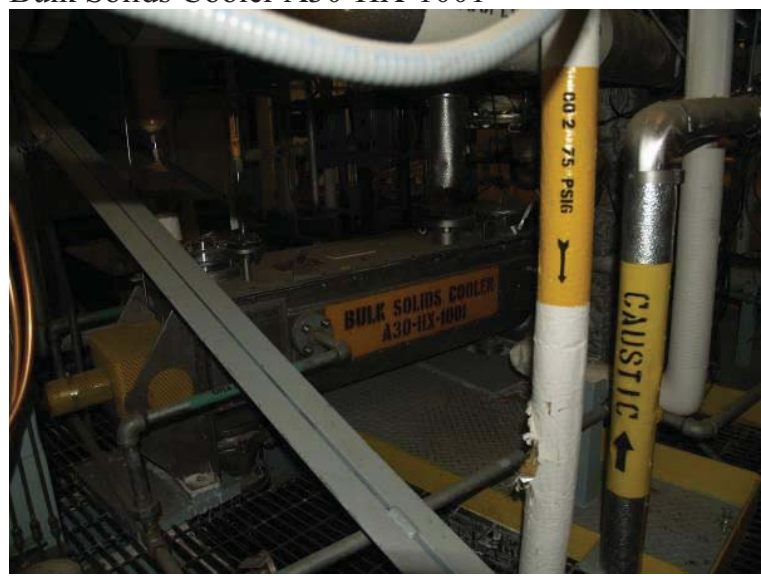


P1015333

Bulk Solids Cooler A30-HX-1001/Suspect Exhaust

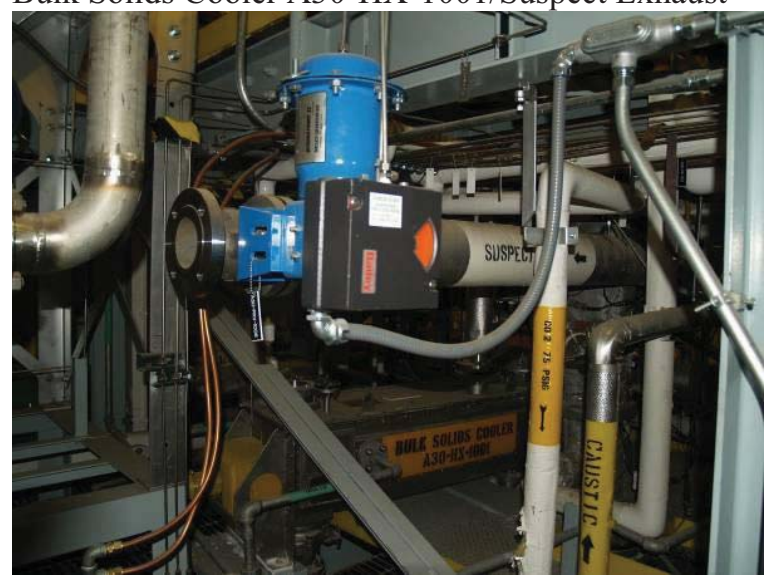

P1015334 Thin Film Evaporator Subsystem (never functioned properly - abandoned in place)

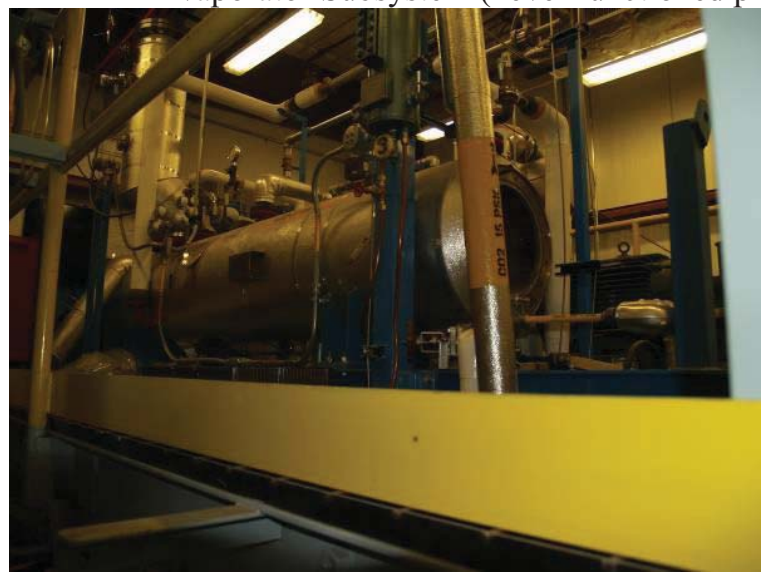

P1015335

Internal Contamination Placard, Flanders HEPA A11-FL-452

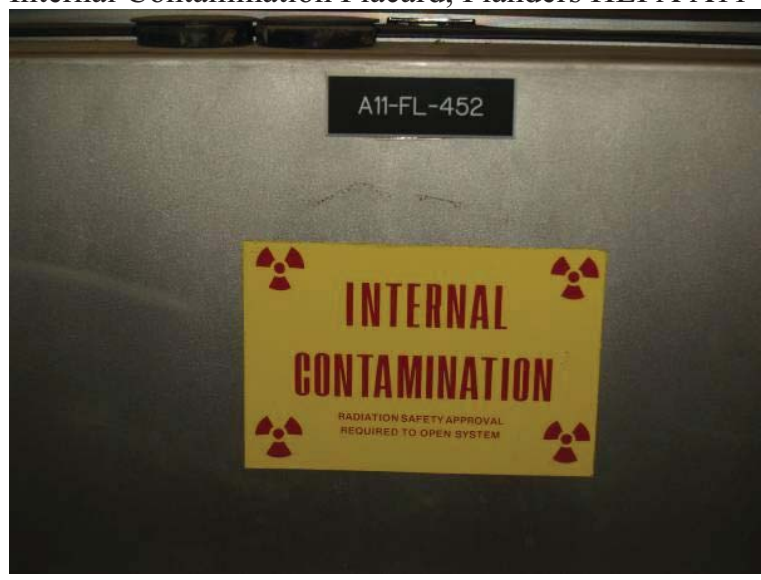


P1015336

Internal Contamination Placard, Flanders HEPA A11-FL-451

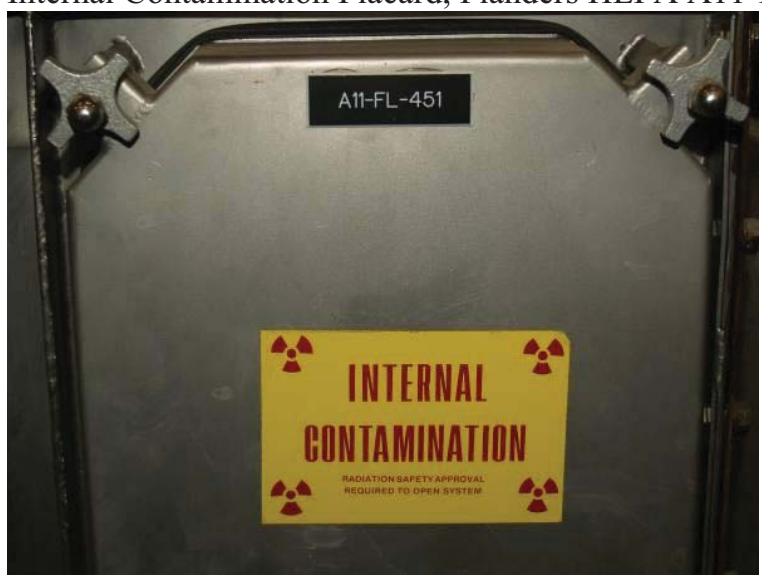

P1015337

P1015338
Control Panel CST-4 for Carbonate Process

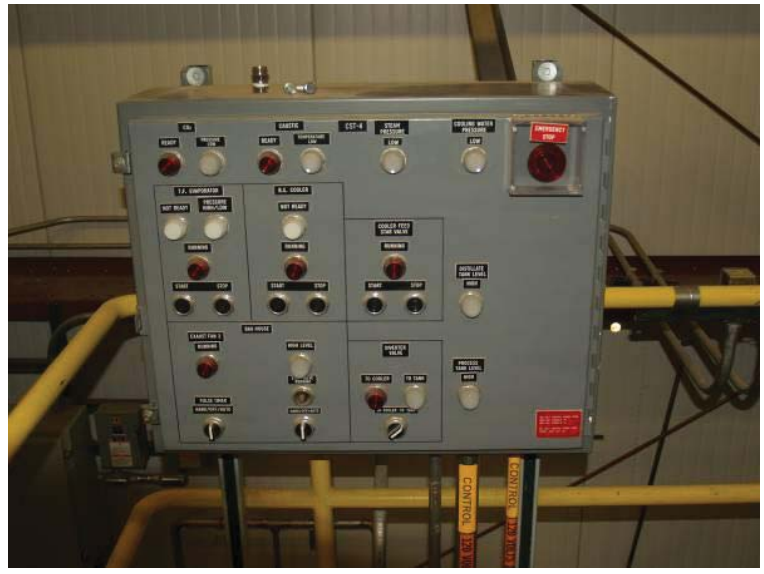

Suspect Exhaust Housing Unit (Torit)

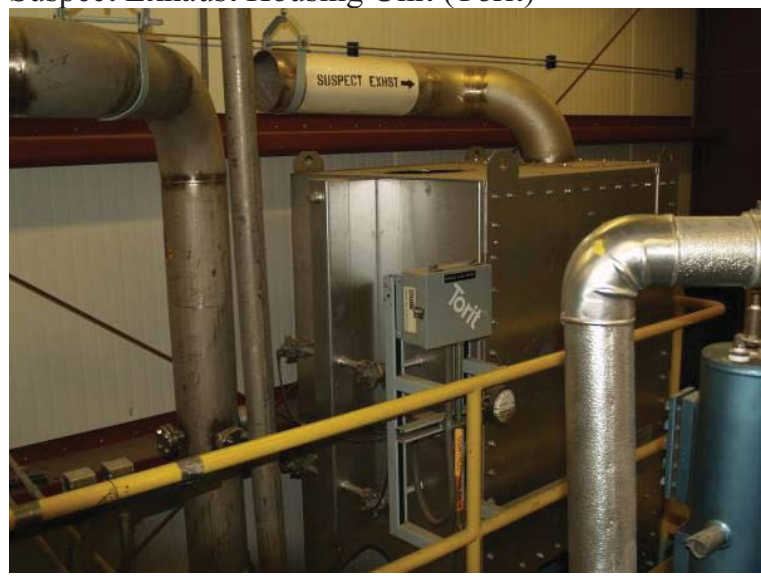


P1015339

Thin Film Evaporator Subsystem (never functioned properly - abandoned in place)

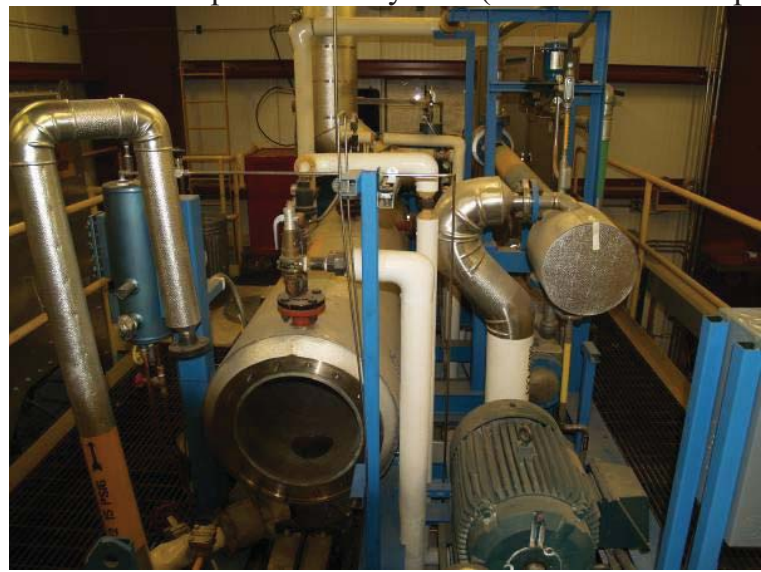

P1015340
Thin Film Evaporator Subsystem (never functioned properly - abandoned in place) (looking north)

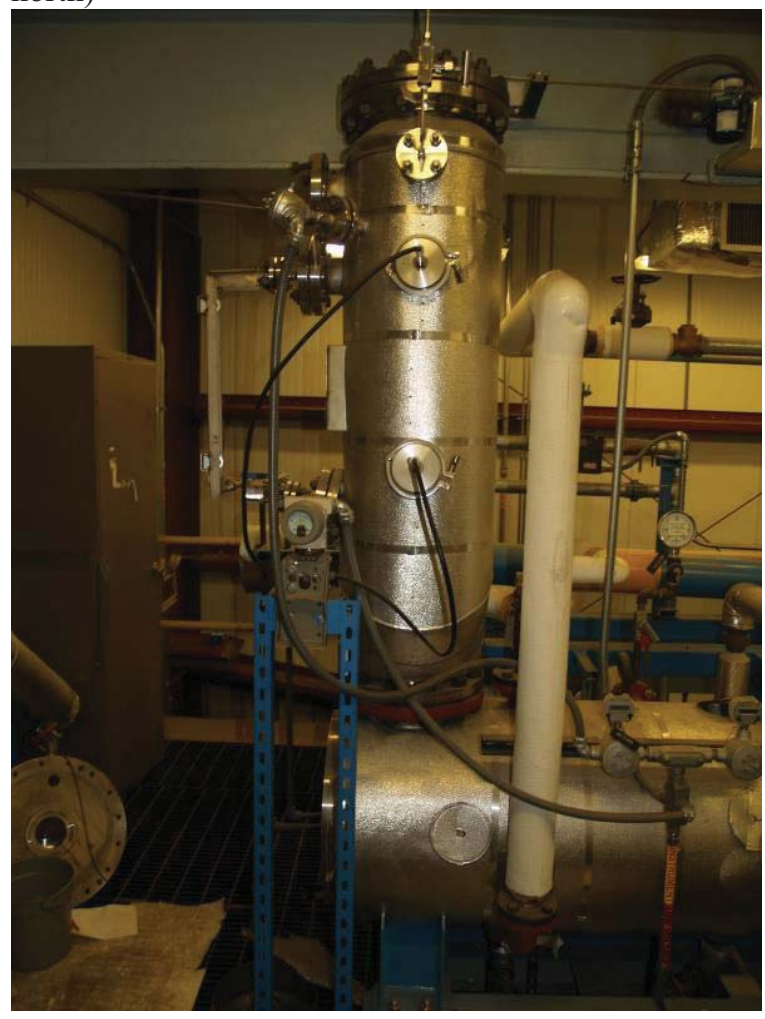


P1015341

P1015342
Thin Film Evaporator Subsystem -Additional Instrumentation (never functioned properly abandoned in place) (looking north)

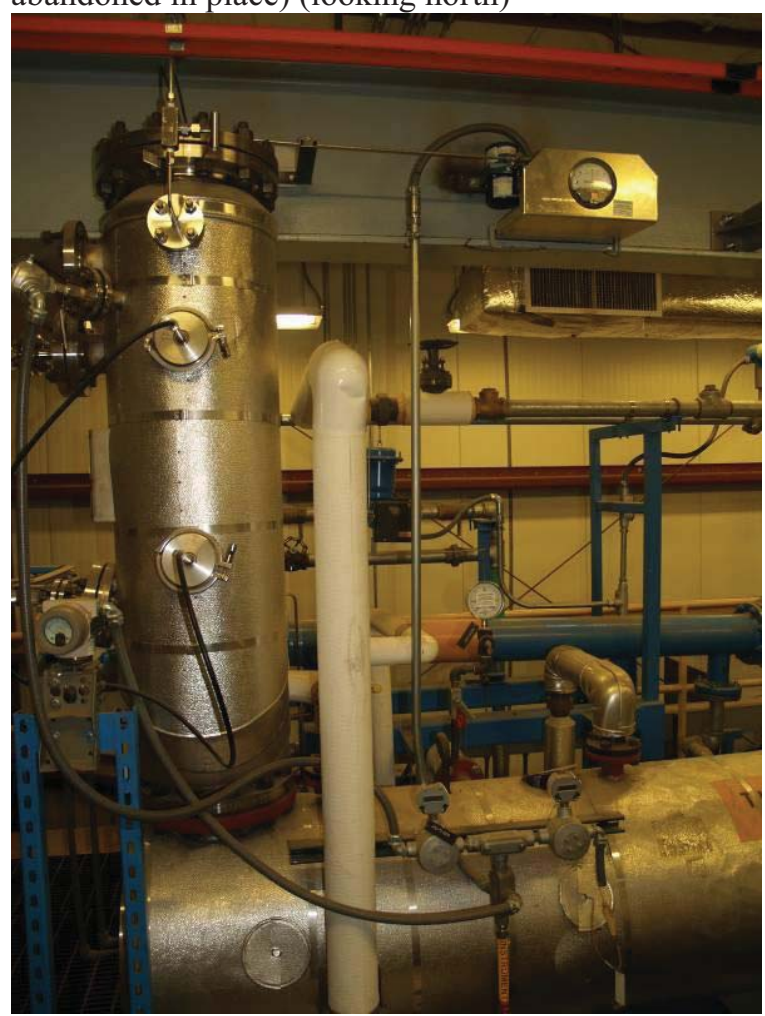

Thin Film Evaporator Subsystem A30-EV-1001 (never functioned properly - abandoned in place)

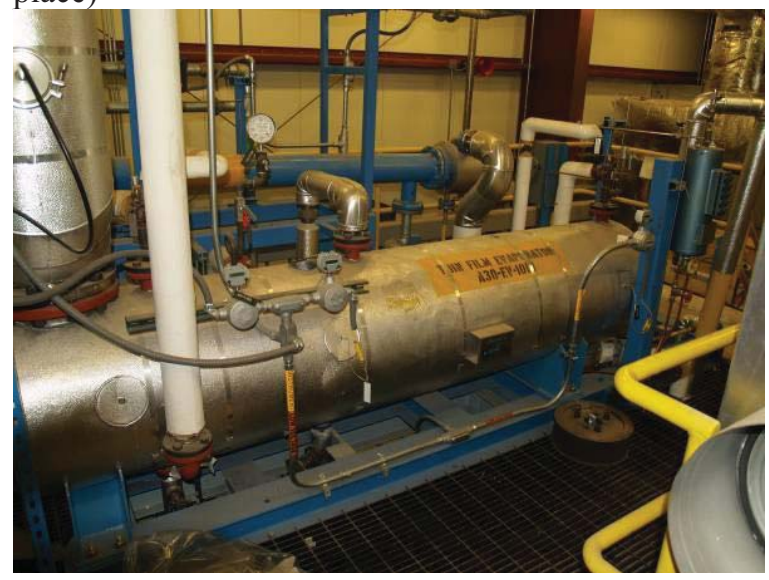


P1015343

Suspect Exhaust Housing Unit (Torit) (looking west)

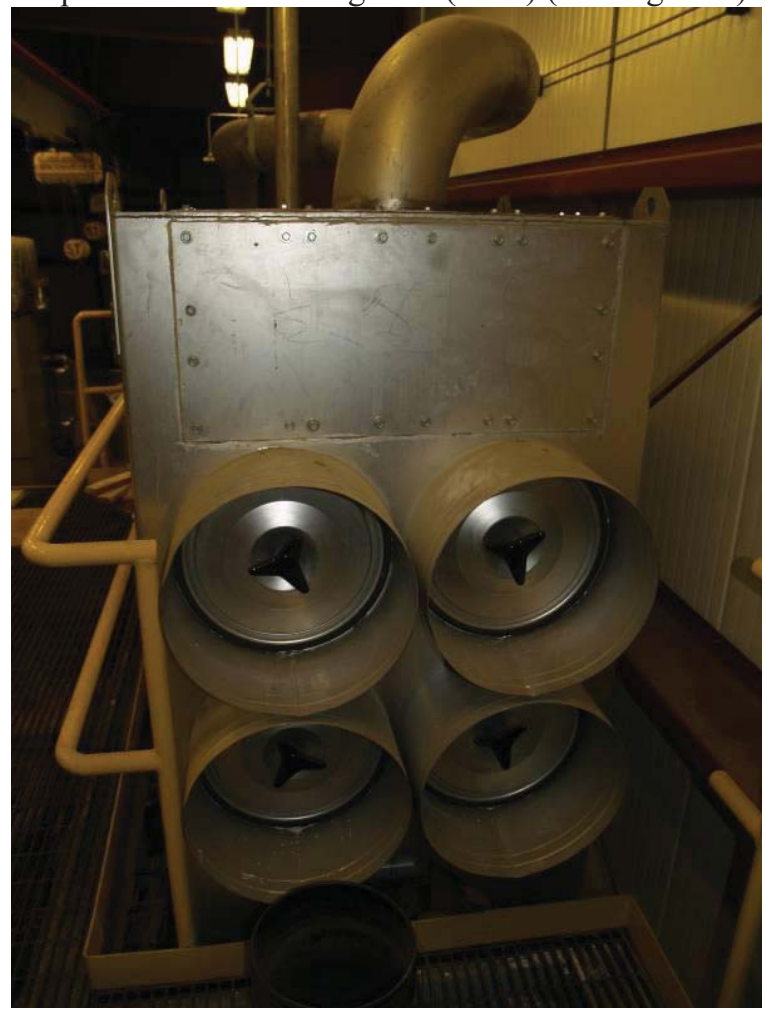

P1015344
HVAC Ducting (looking northeast)

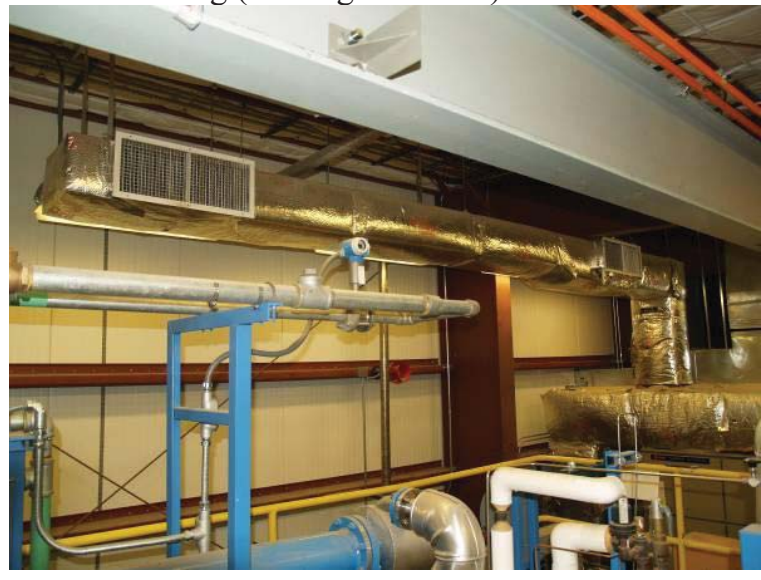


P1015345

P1015346
TRANE/SpaceMaster II 5-ton Electric Hoist (looking northeast)

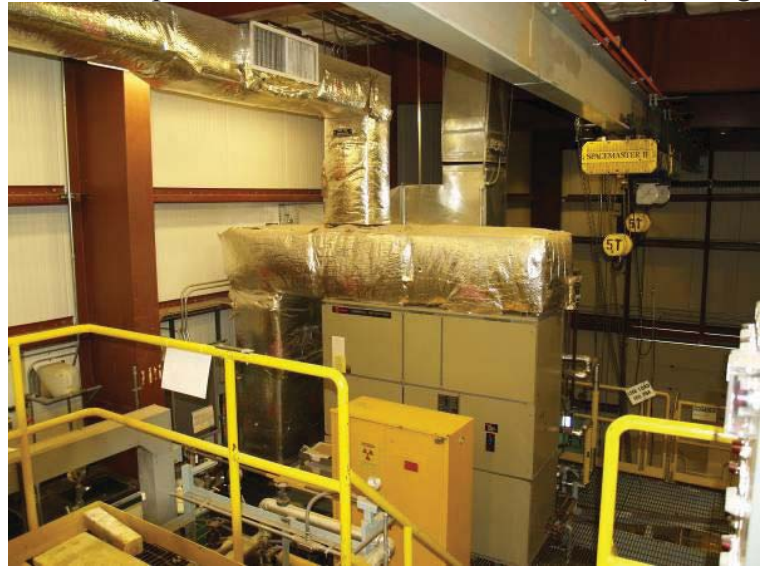

Closeup of SpaceMaster II 5-ton Electric Hoist (two units)

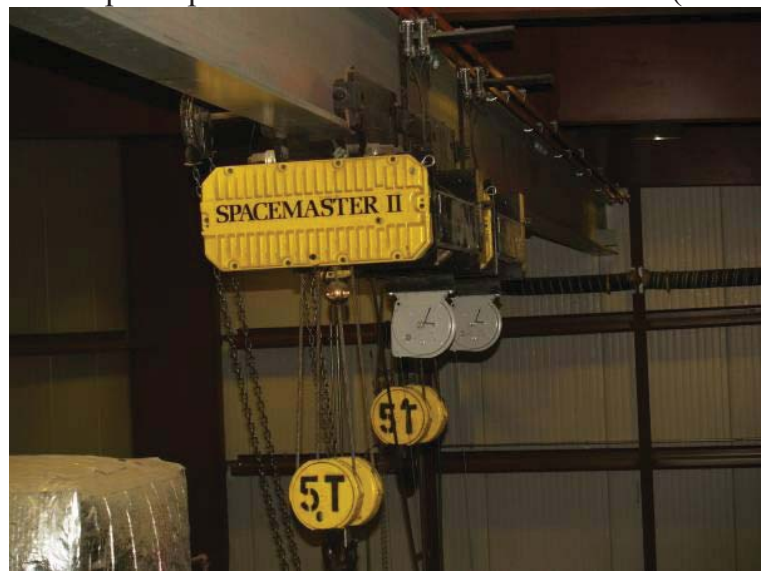


Sodium Processing Facility MFC-799 - Sodium Processing Facility Control Room

P1015347

Eberline Hand and Foot Monitor - south door, Control Room

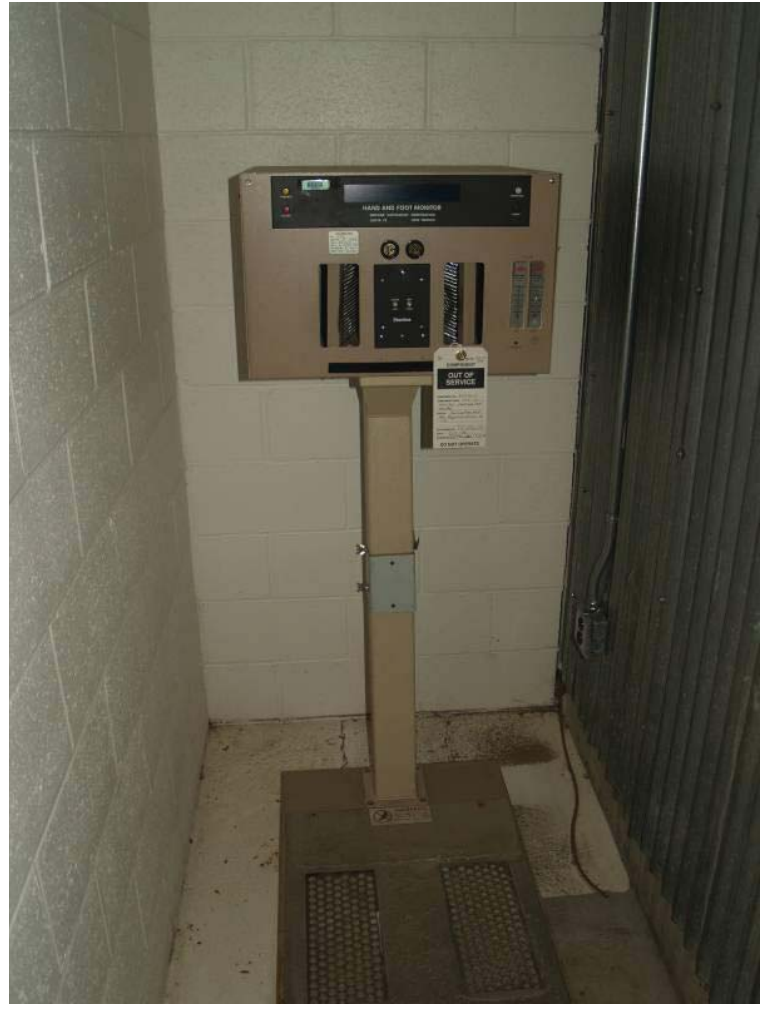

P1015348

Inside South Door, Control Room (looking east)

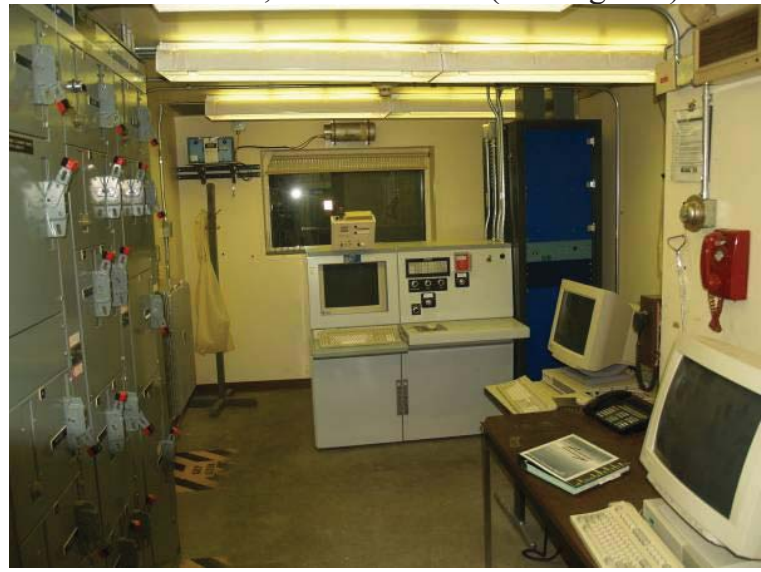


P1015349

South View - MCC AN1 (looking south)

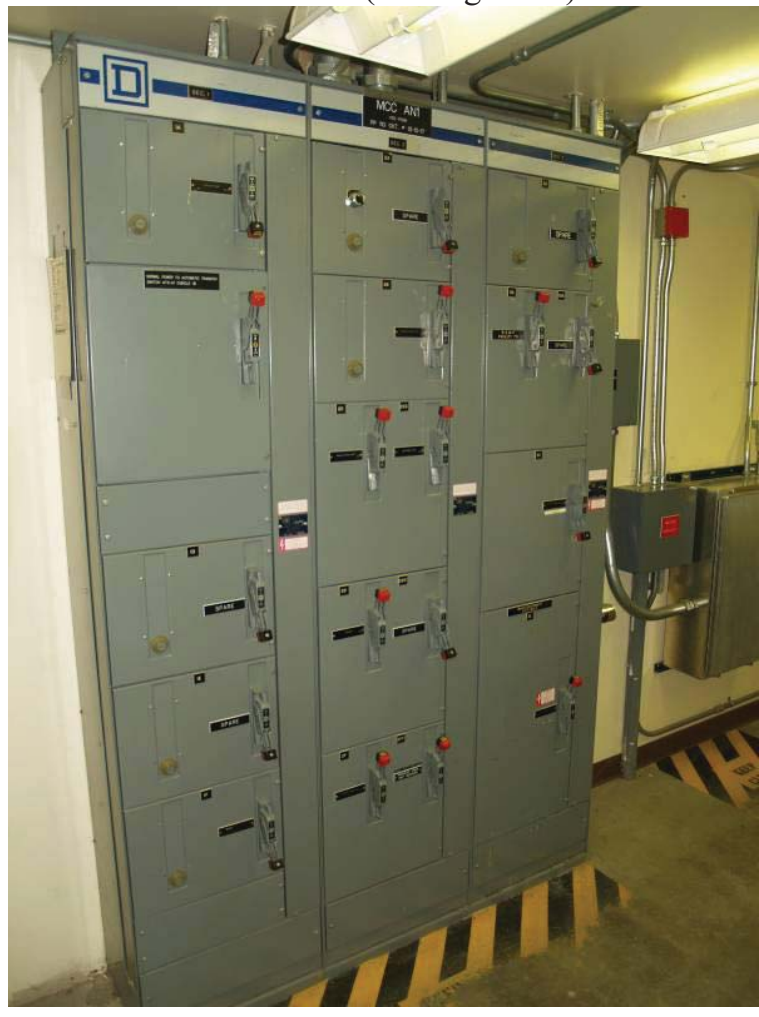

P1015350

3B Circuit for RSWF Facility 771 (MUST BE MAINTAINED!)

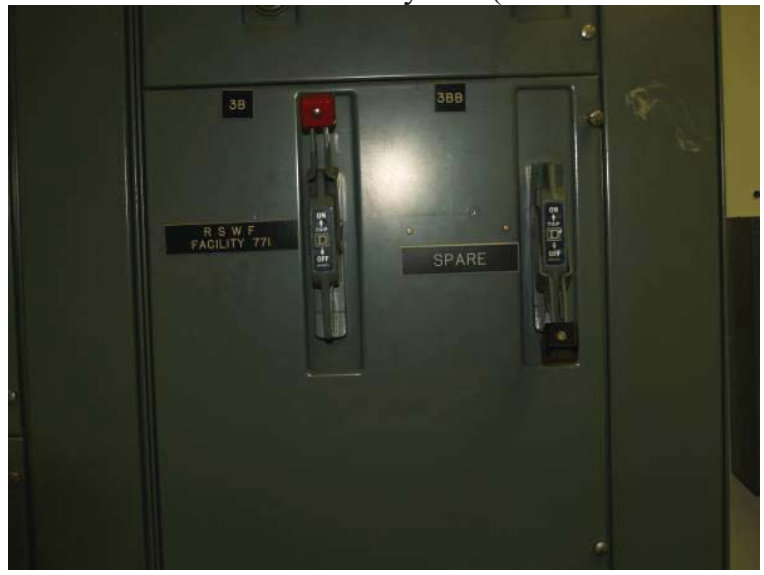


P1015351

MCC AN1 Fed From PP 110 CKT \#13-15-17

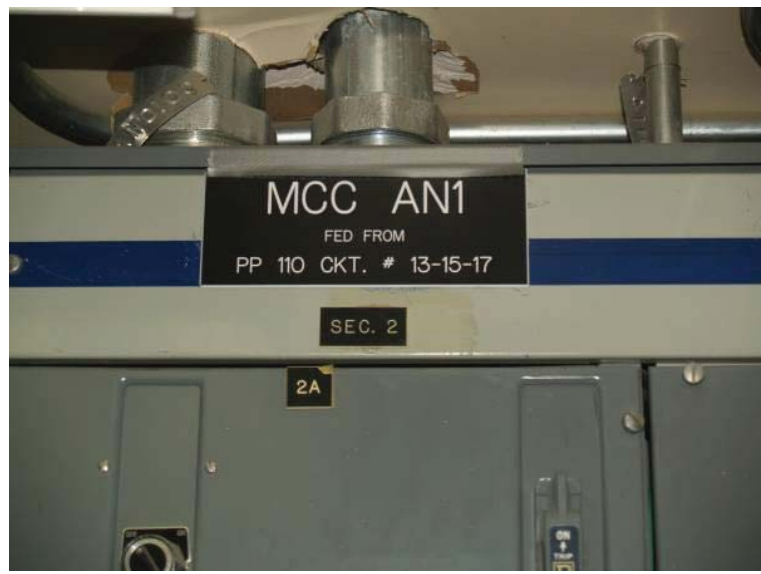

P1015352

Fire Alarm Terminal Box and Communication Boxes (looking north)

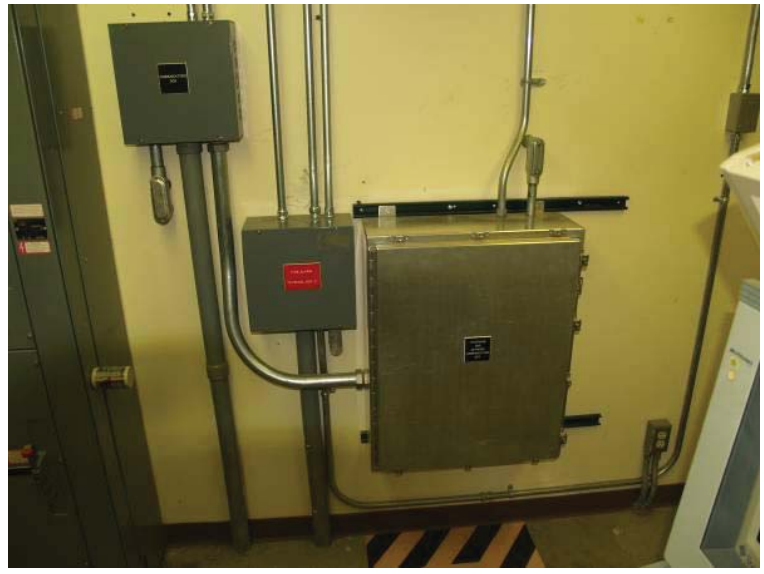

P1015353 RAM Station 1 - Southeast Wall

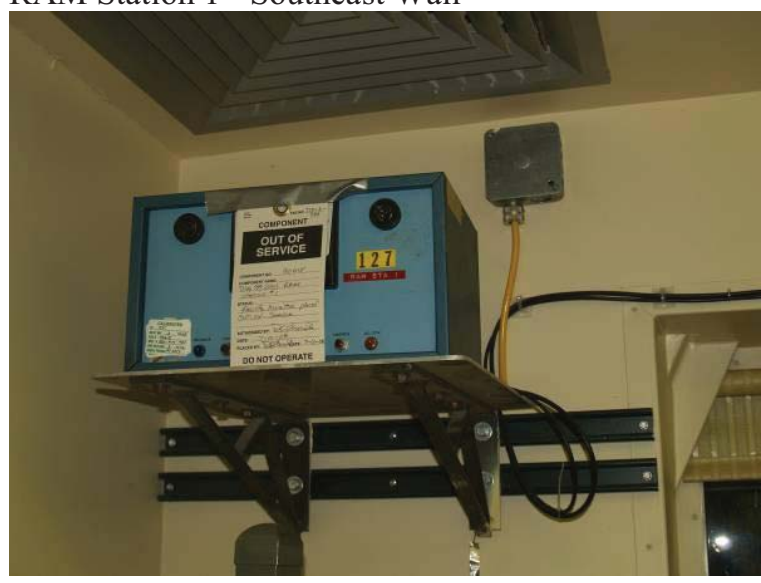


P1015354

RAM Intake

P1015355

P1015356

Sun Station

HP Station
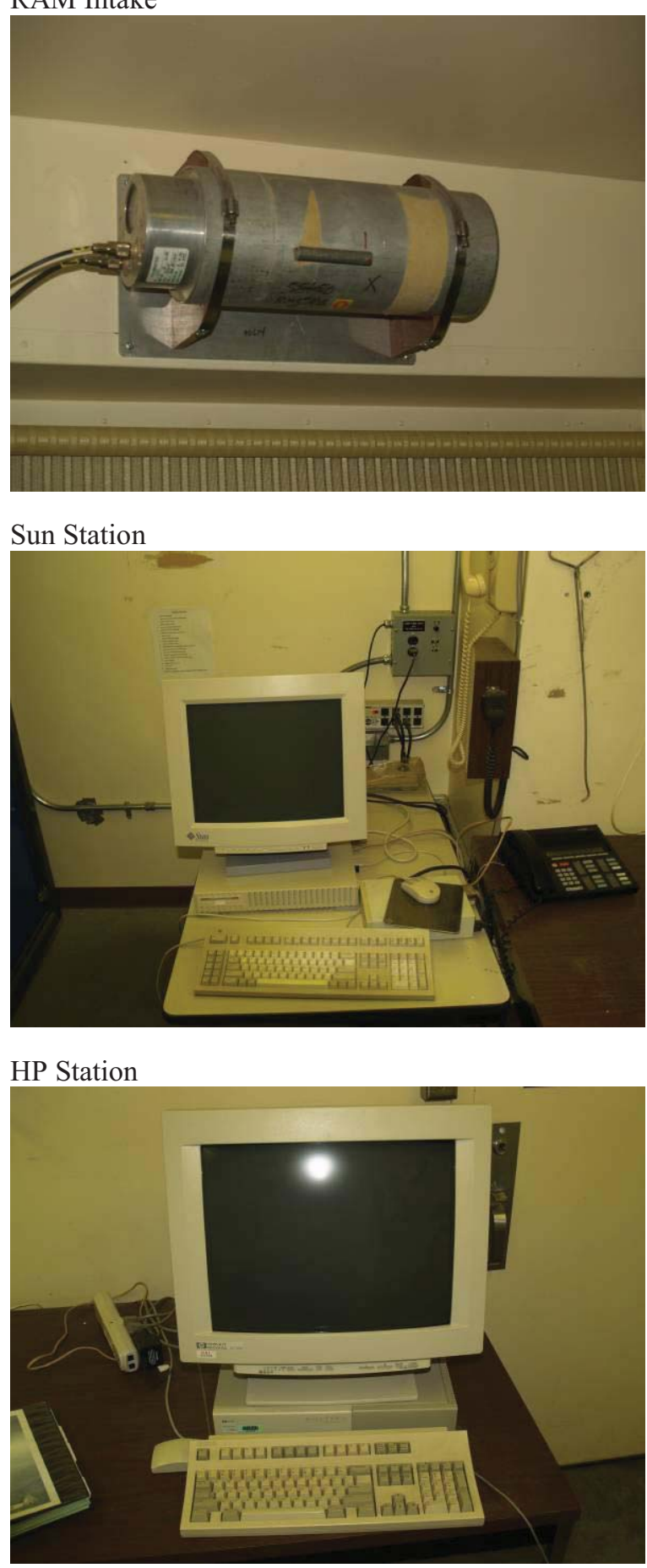


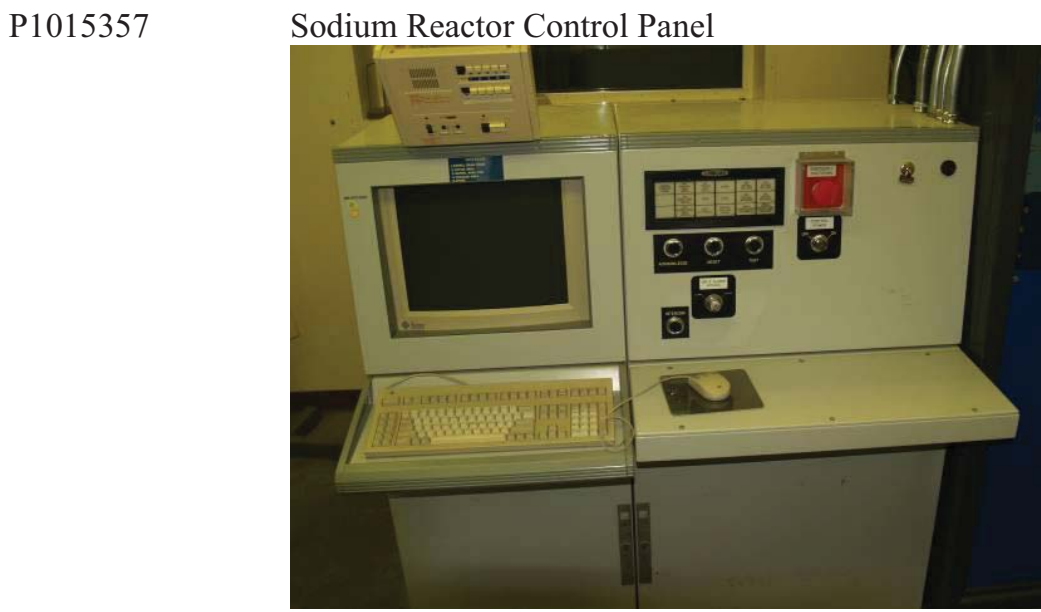

P1015358

Instrumentation Cabinet

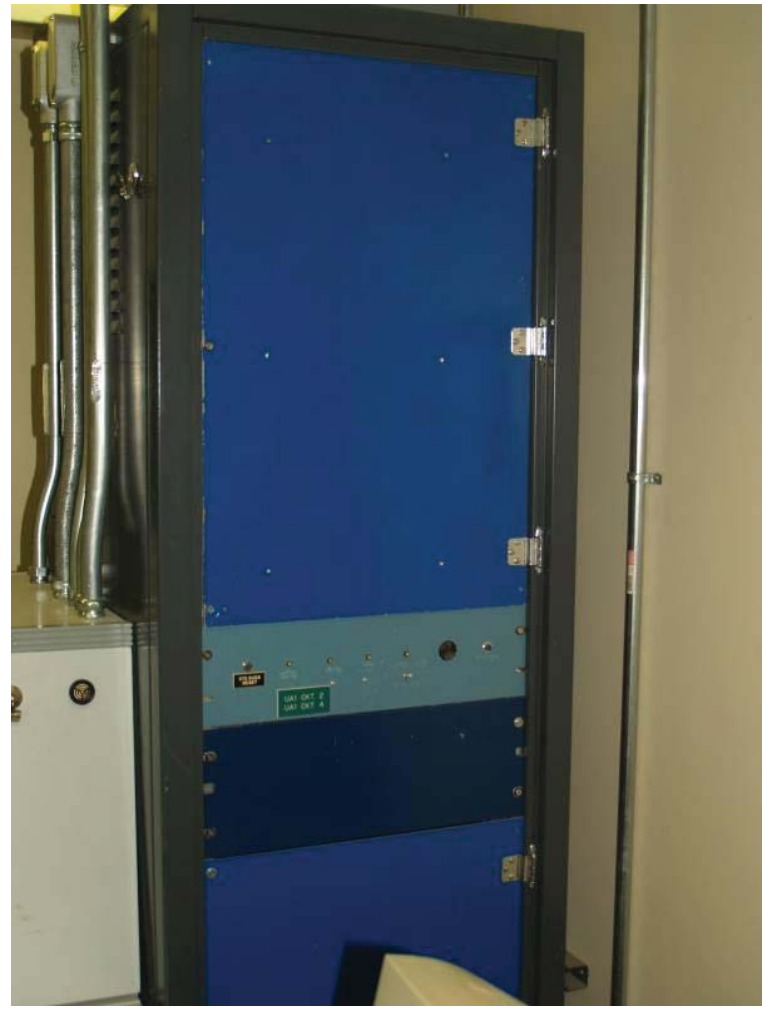


Sodium Processing Facility MFC-799 - Sodium Processing Facility Operations Office

P1015359

Inside South Door (looking northeast)

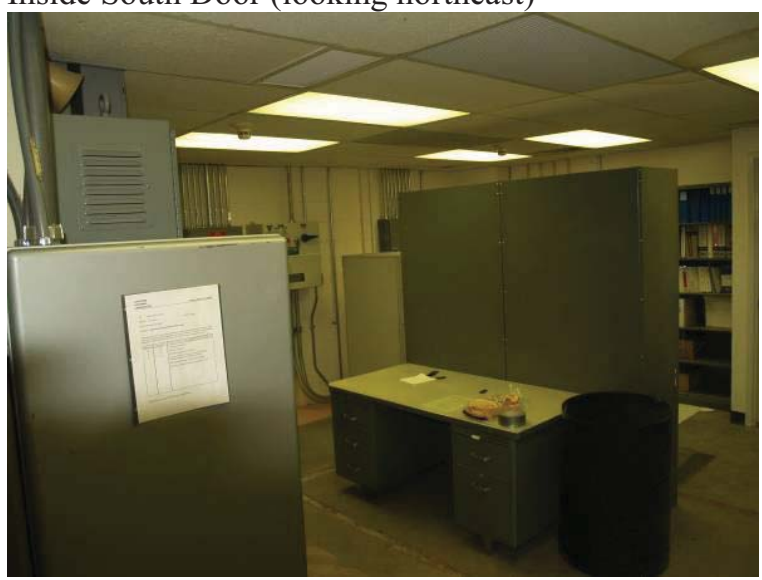

P1015360

Inside South Door (looking north)

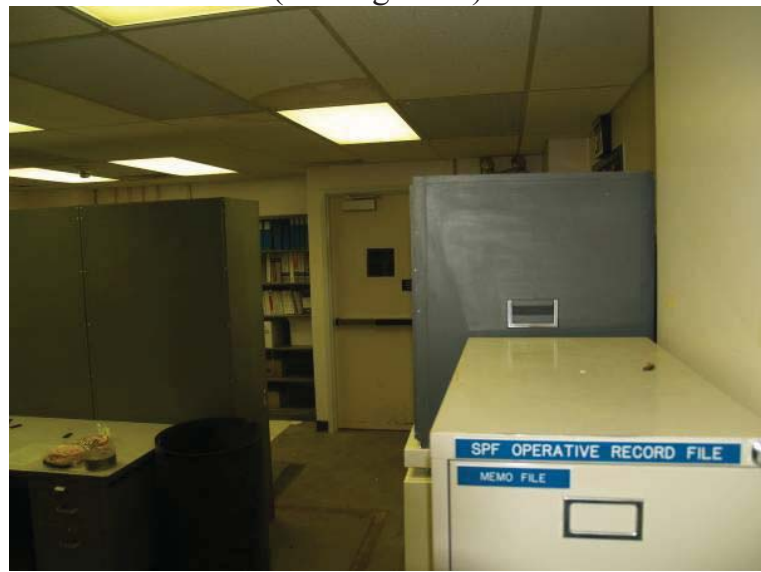


P1015361

P1015362
Sodium Processing Facility Operating Record File Cabinet

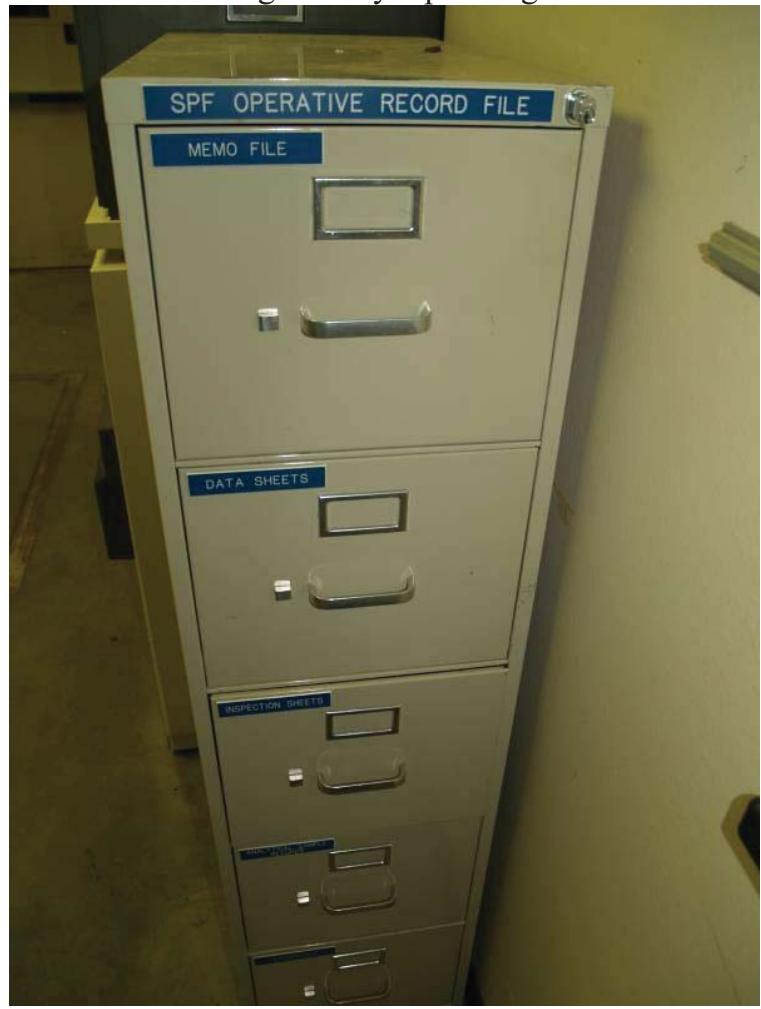

Sodium Process Facility Hydrogen - Oxygen Area Monitors

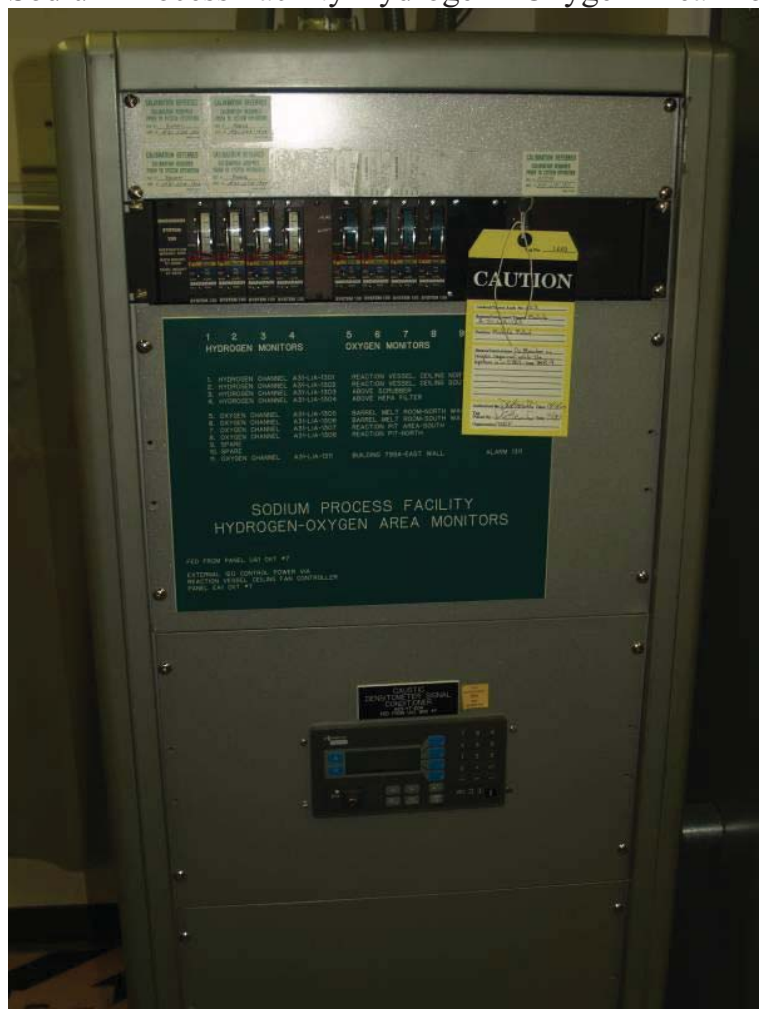


P1015363

P1015364

P1015365
I/O Cabinet for Carbonate System (looking south)

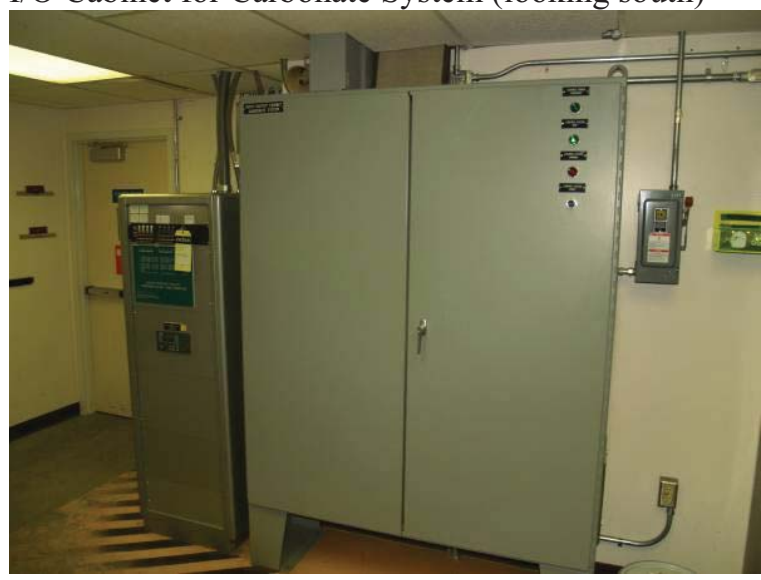

Storage Cabinet by Southeast Door

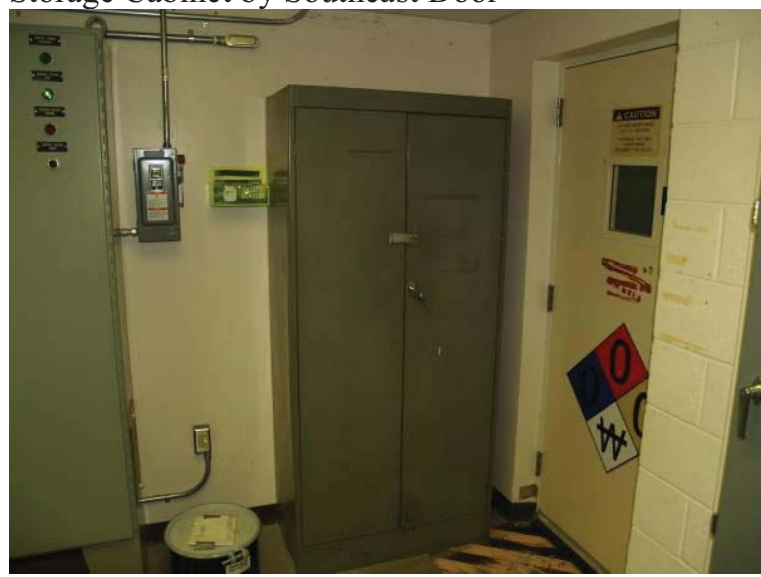

EA1 Emergency Power fed from MCC-AE1 Cabinet/UPS Maintenance Bypass Cabinet

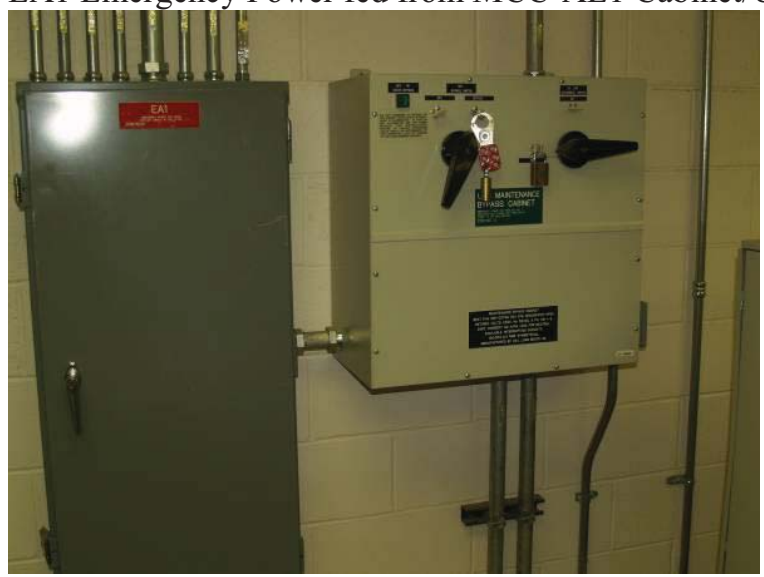




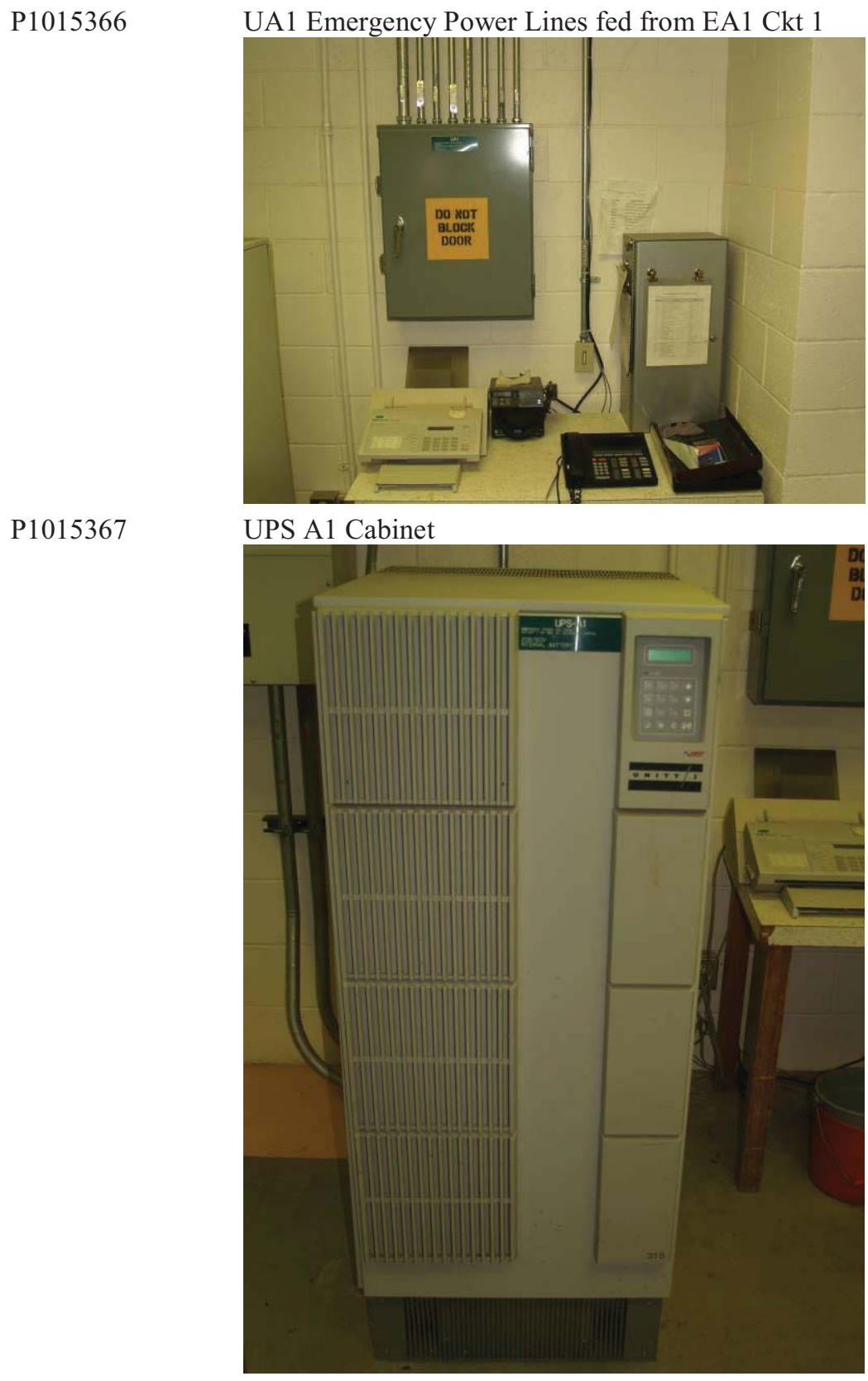




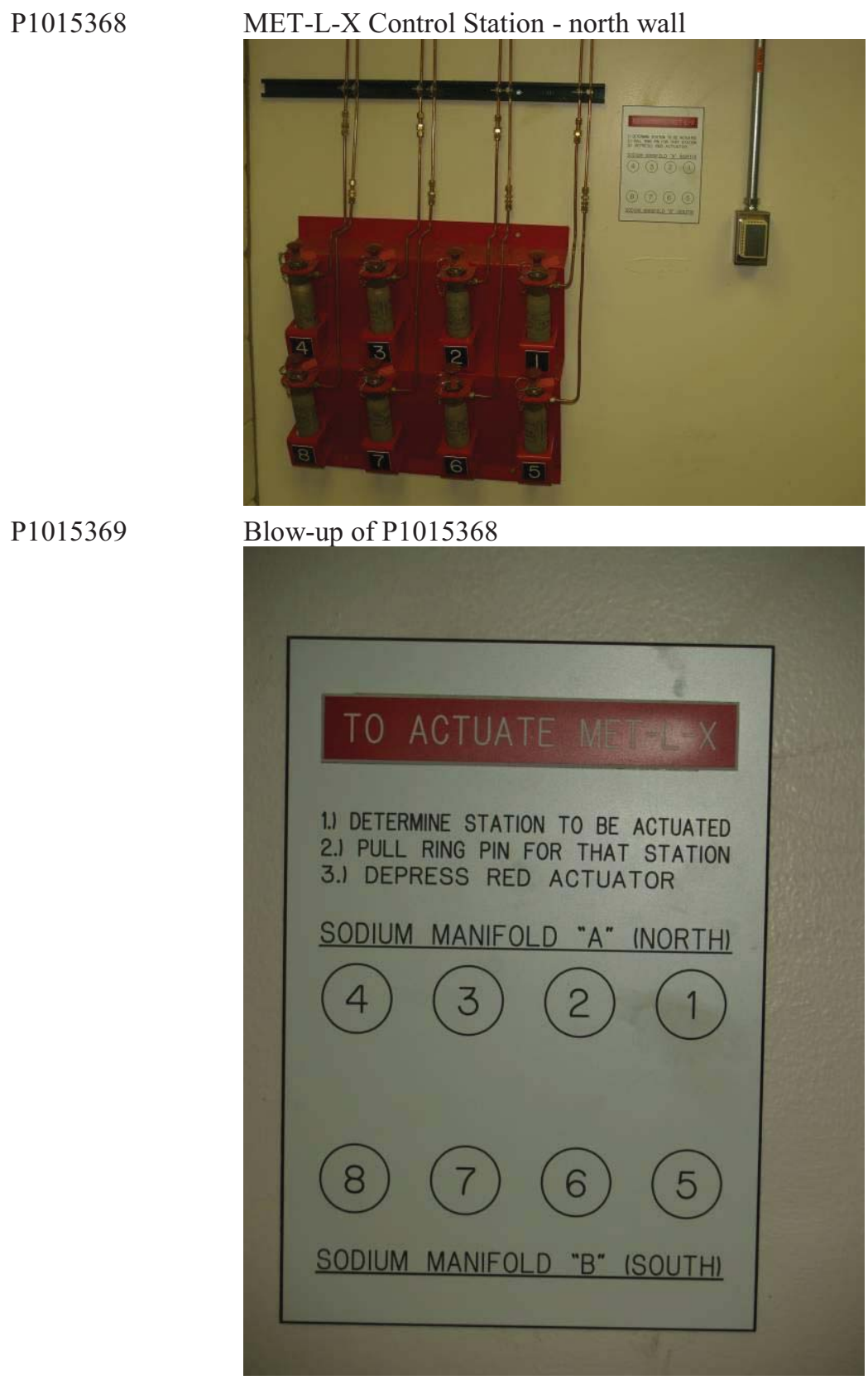


P1015370

Reference Materials/Control Units (looking west)

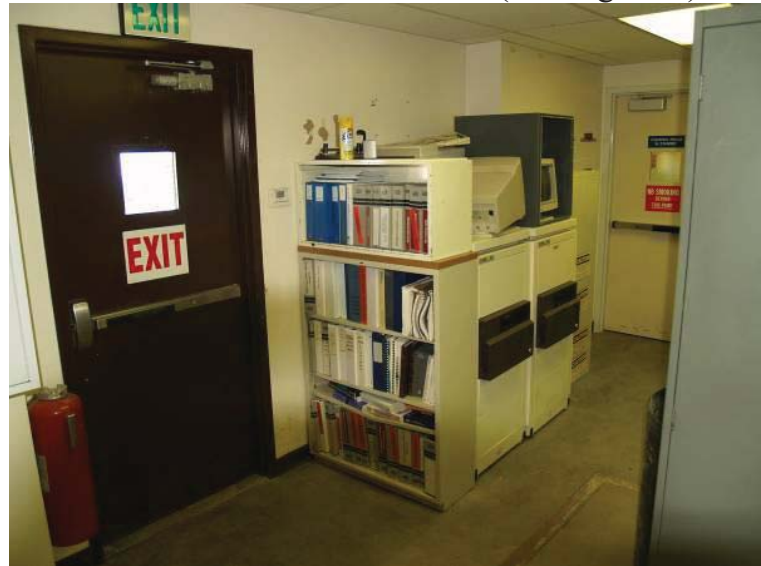

P1015371

P1015372

Storage Cabinets (looking west)

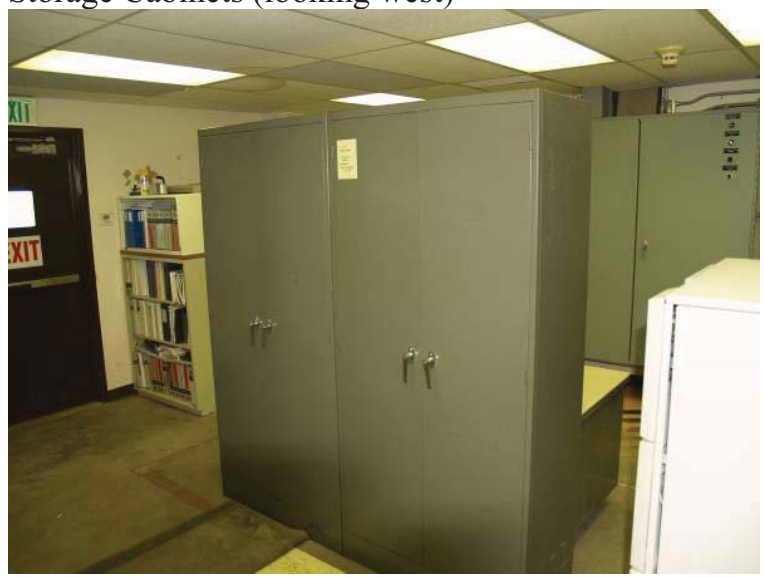

North Door - Spill Control Station/Reference Materials/Fire Blanket, Extinguisher

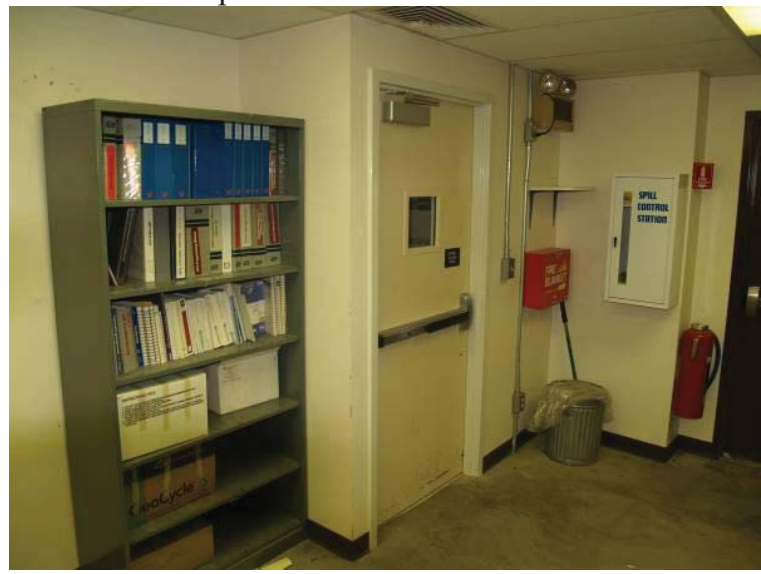




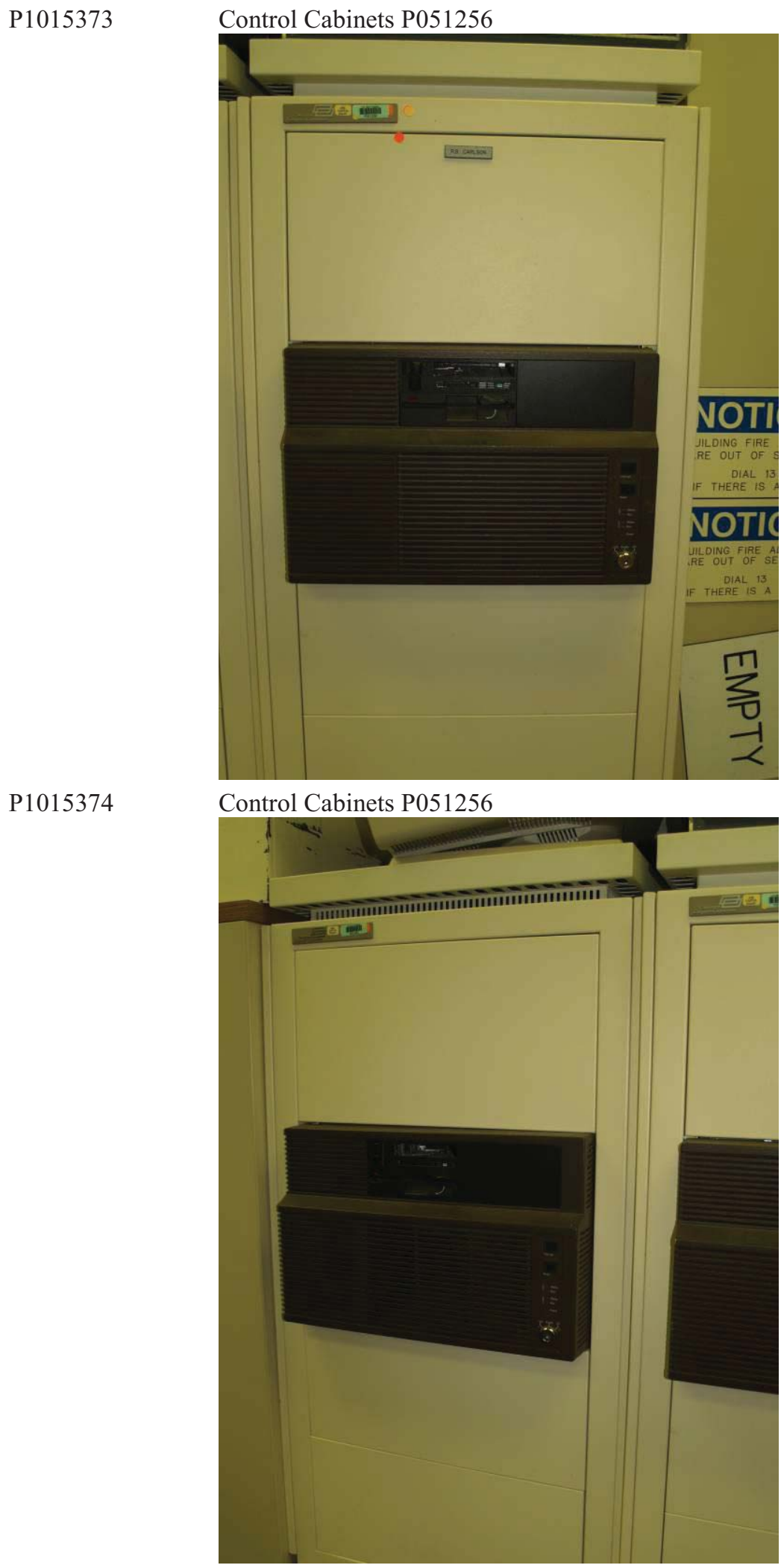


P1015375 Magnetic Caution Signage

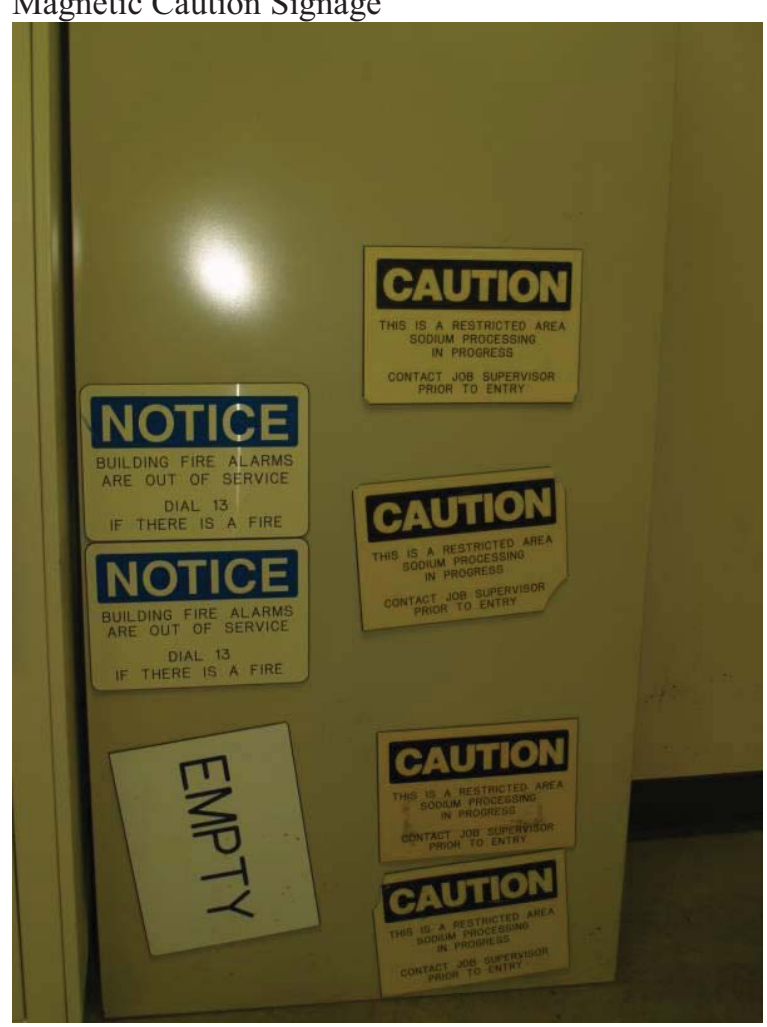

Sodium Processing Facility MFC-799 - Sodium Processing Facility Barrel Holding Room P1015376 P\&H Spectrum 1,000-lb Pedestral Crane

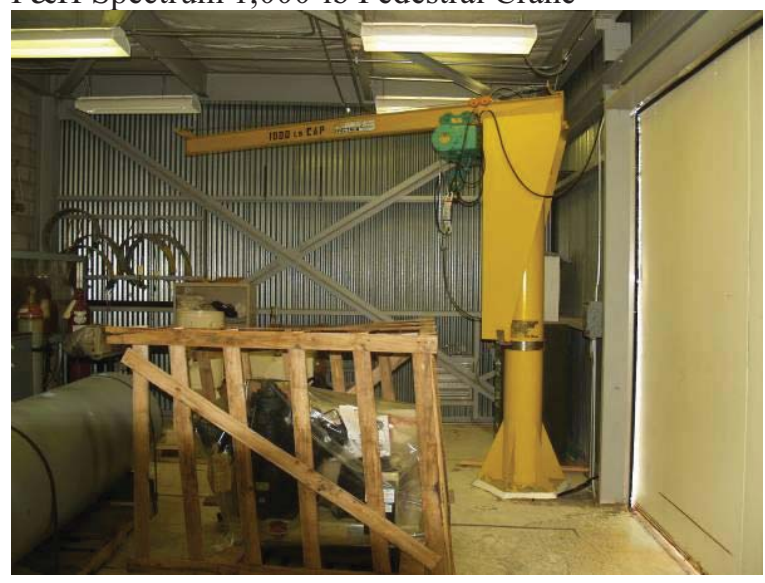


P1015377

P1015378
6 x 6 Sliding Door/Misc Storage (looking northeast)

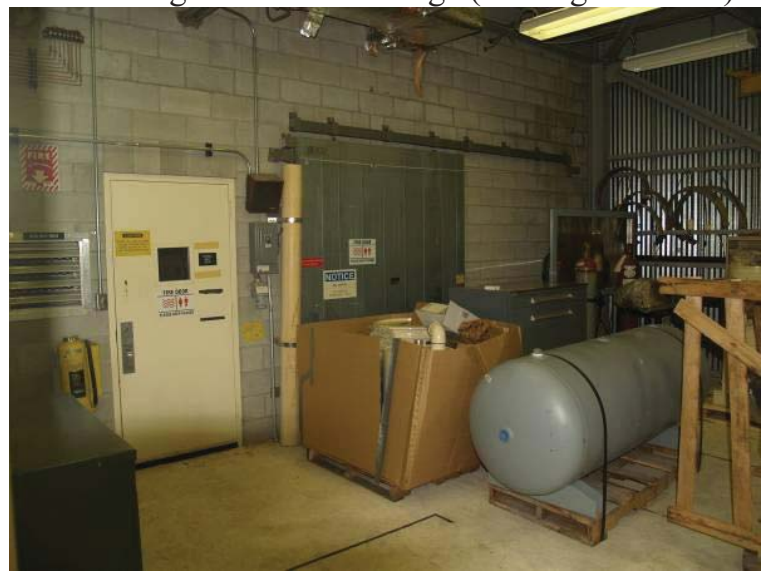

Eberline Hand and Foot Monitor (looking south at north door of Operations Office

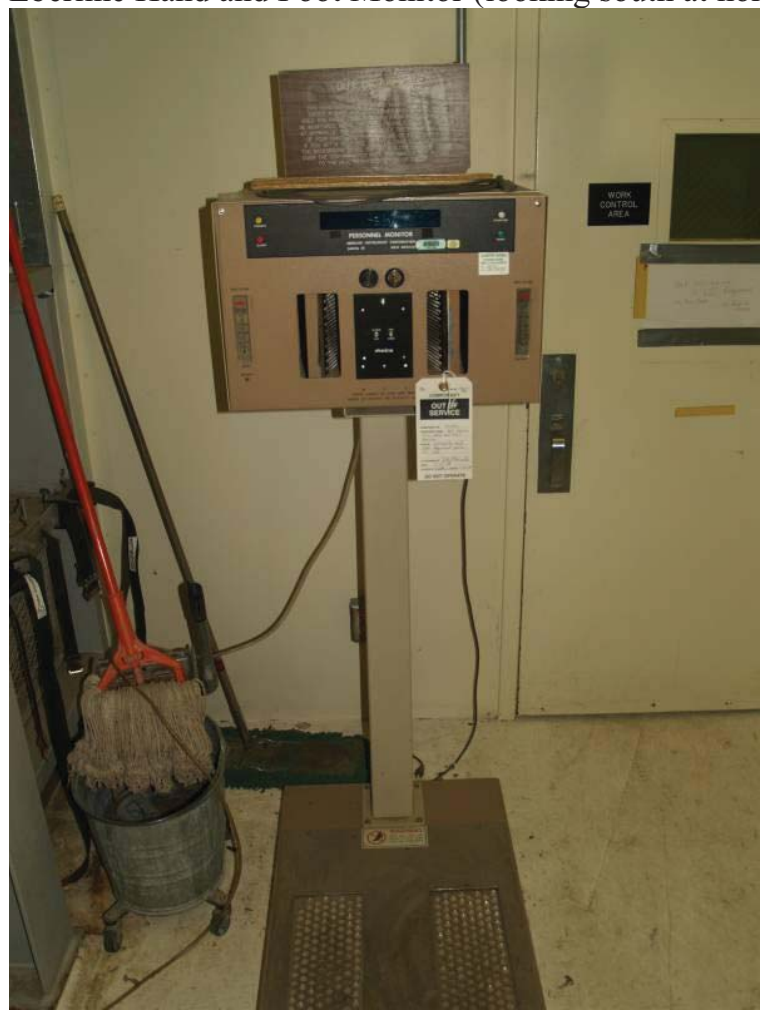


P1015379

P1015380
Transformers/Control Panels for Sodium Melting Draining Room - South Wall

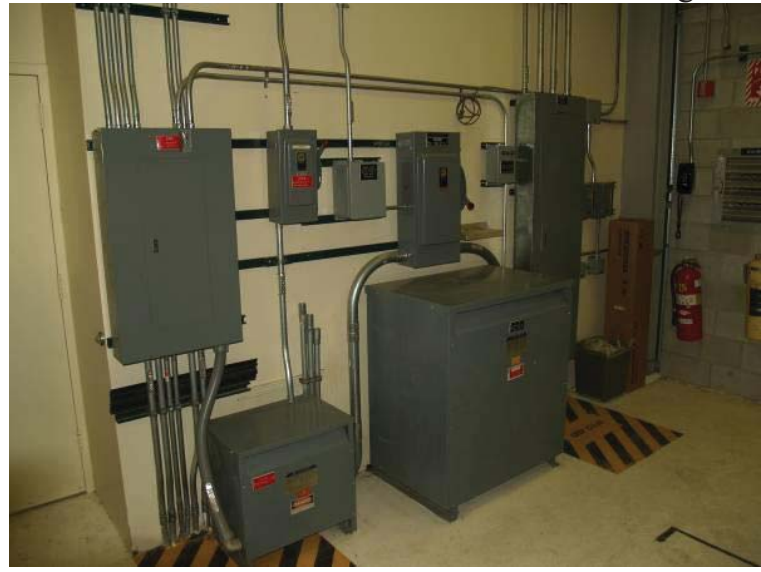

PD080 Heater Transformer Disconnect

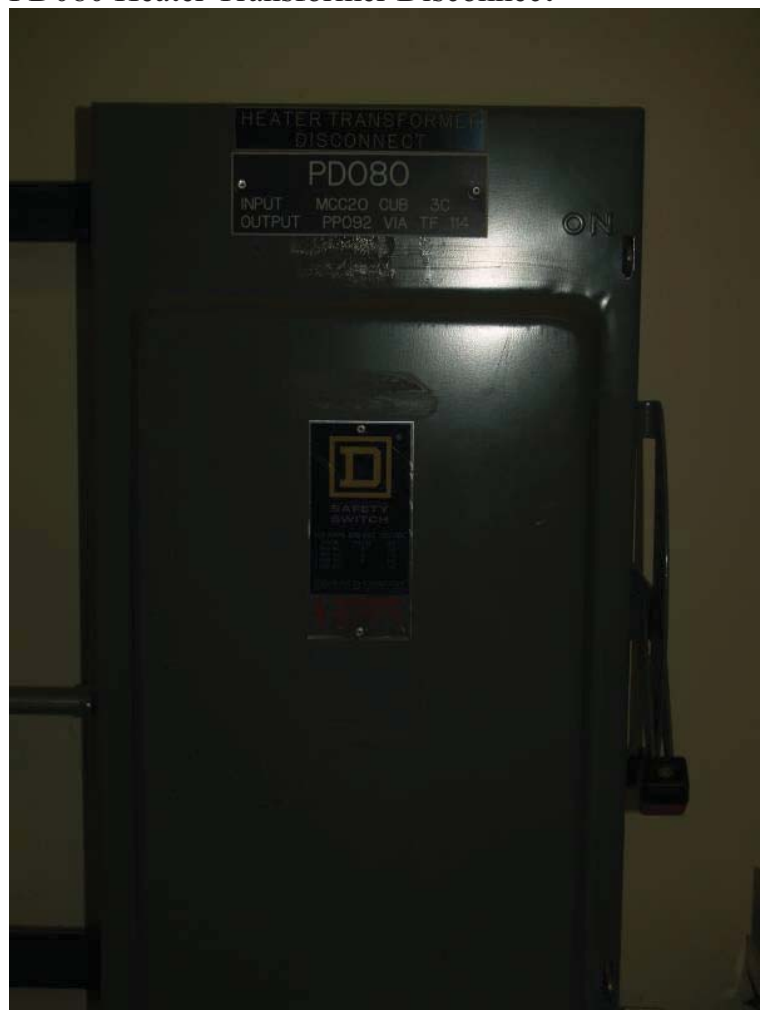


P1015381

P1015382

P1015383
Palletized Equipment -- North Side of Room

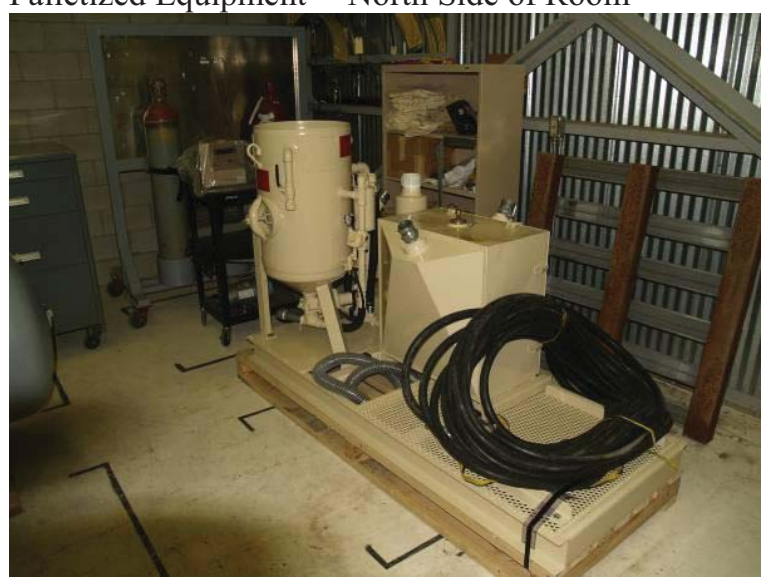

RAM Equipment (on wheeled cart)

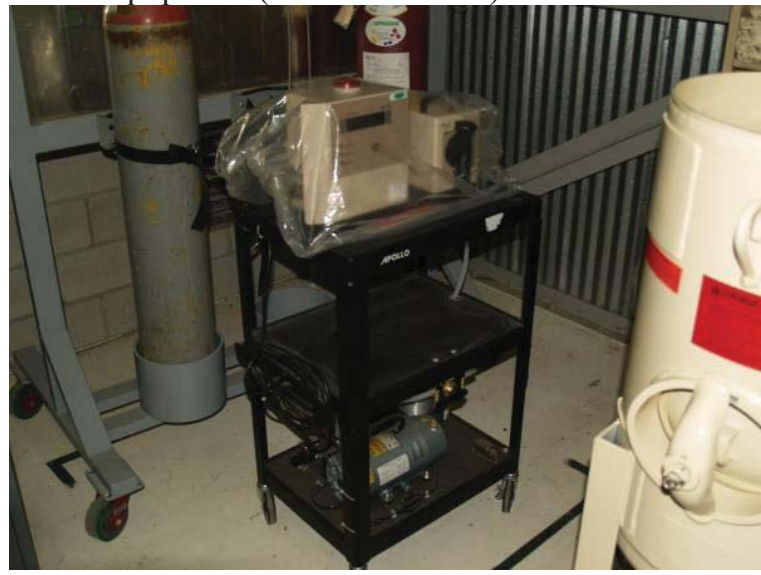

Rolling Storage Cabinet (RAD Supplies)

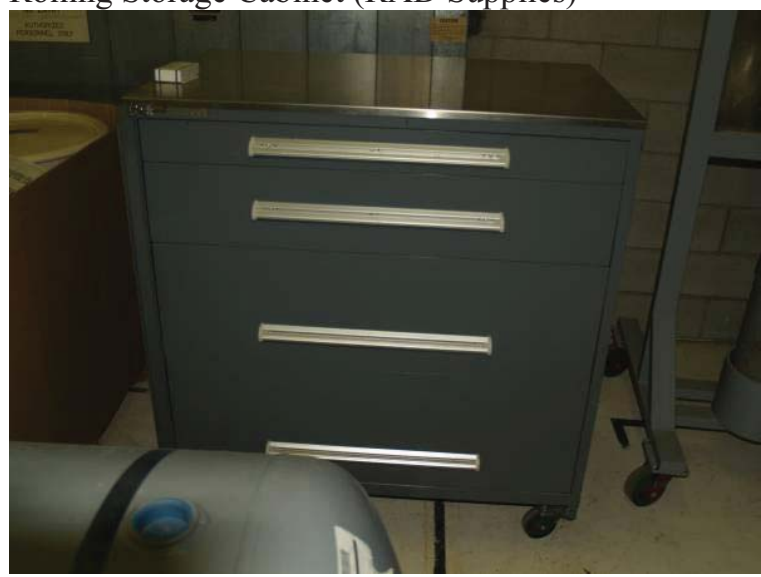




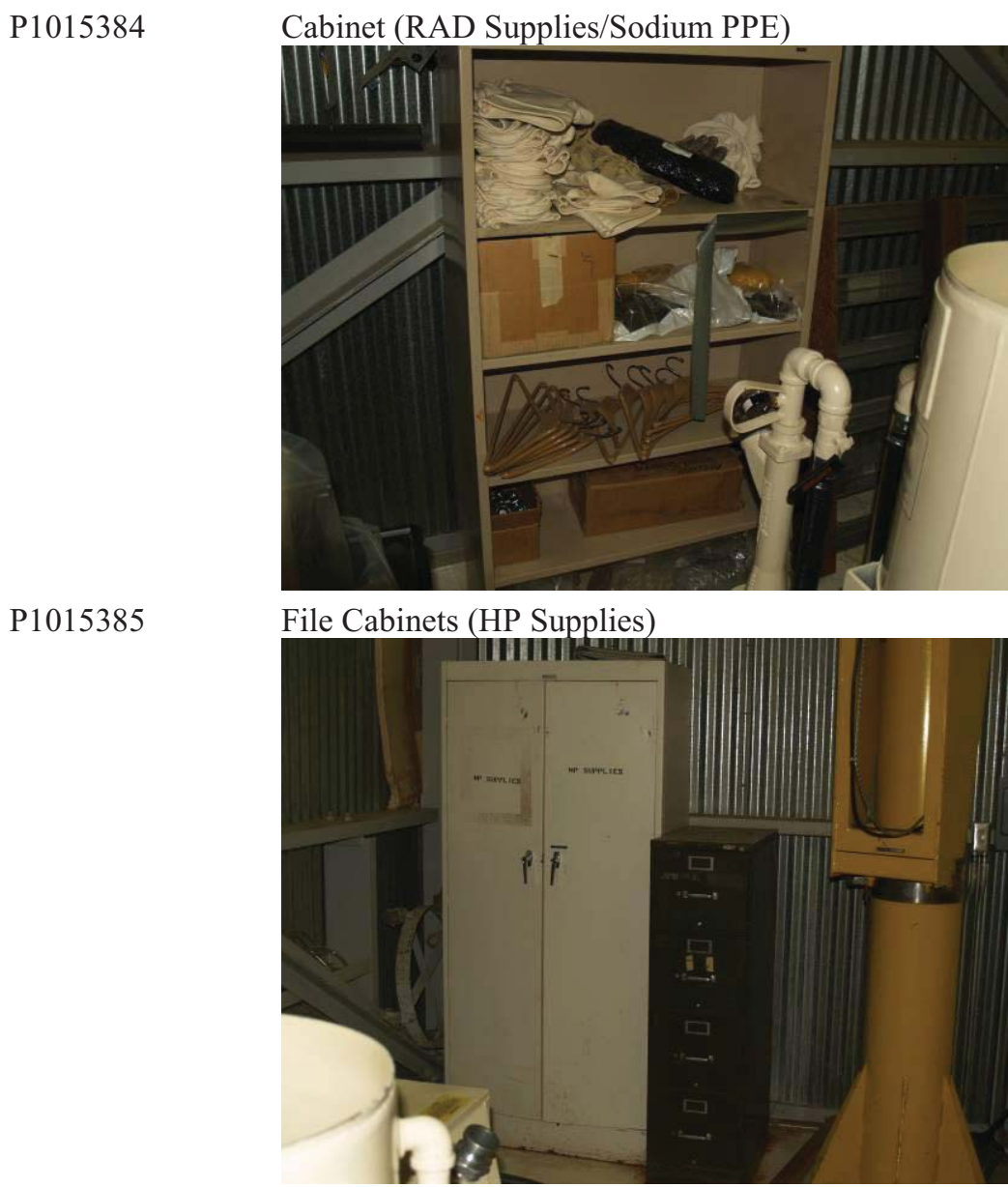


P1015386

P1015387
Pedestal Crane (looking west)

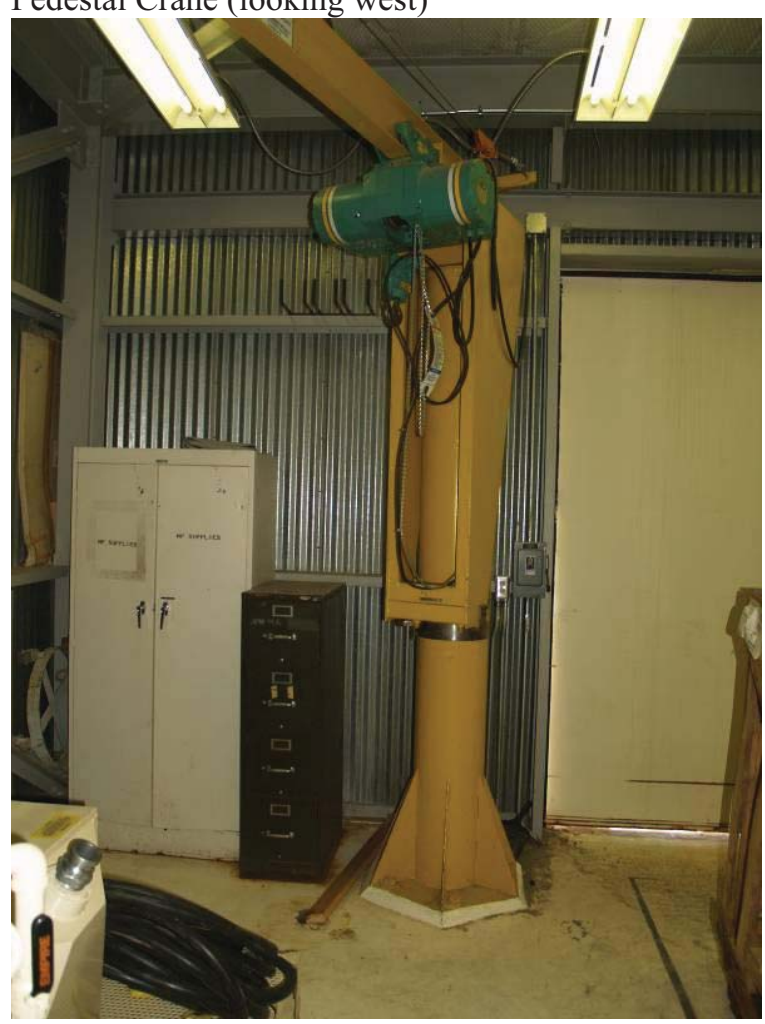

Larger View Transformers/Control Panels for Sodium Melting Draining Room - South Wall

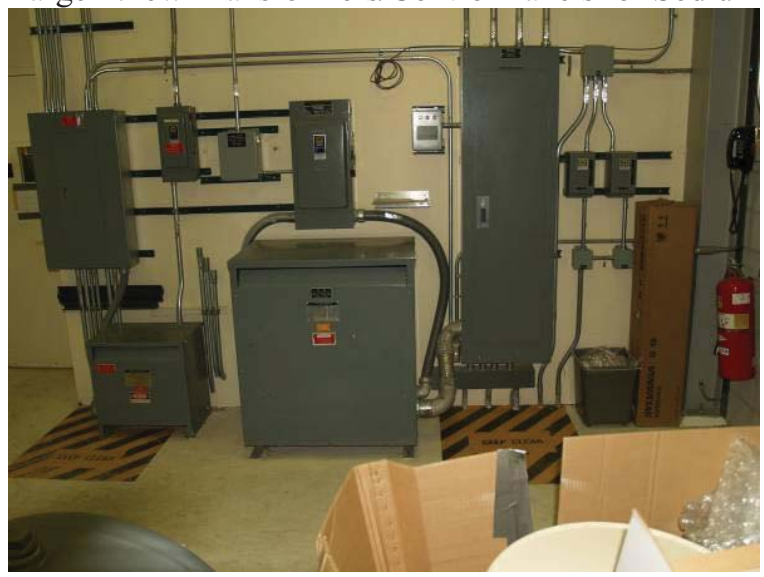


P1015388

P1015445

P1015446
Main Sliding Door - west side

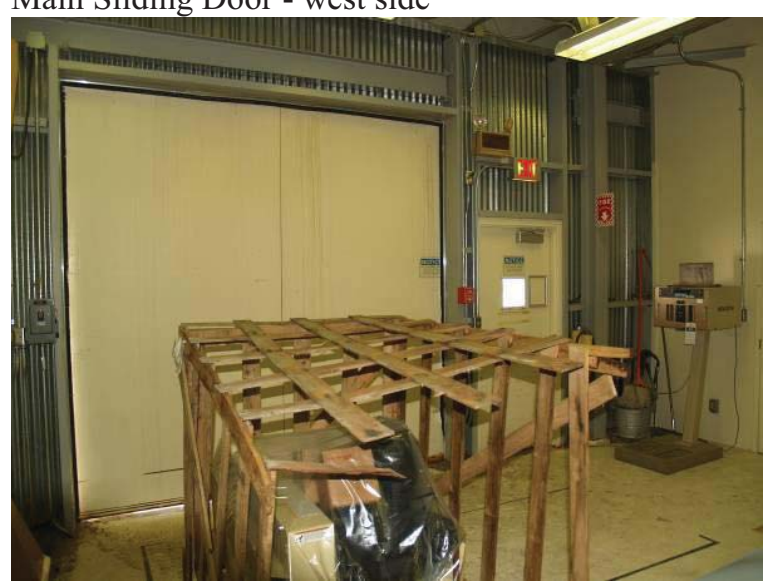

Portable Instrumentation Board

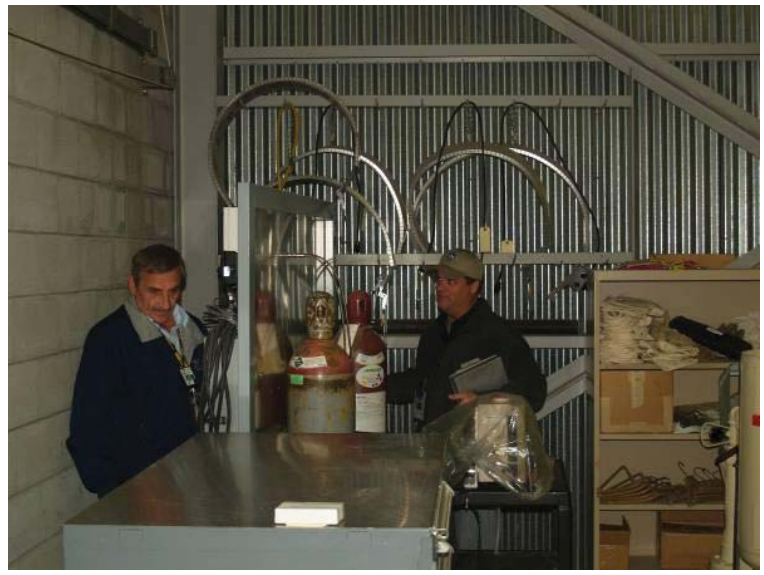

Barrel Holding Room (looking northwest) (NOTE PALLET MARKINGS ON FLOOR)

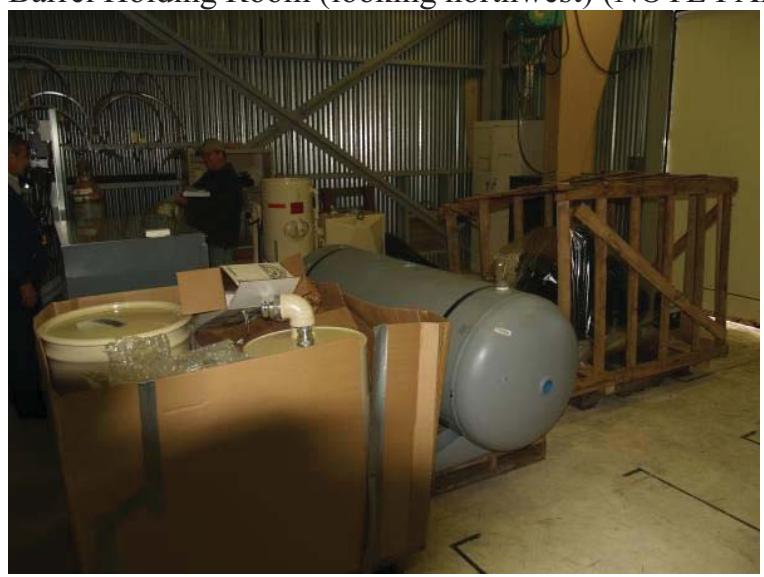


Sodium Processing Facility MFC-799 - Sodium Melting Draining Room

P1015389

Inside Personnel Door, Manifold B (Looking East)

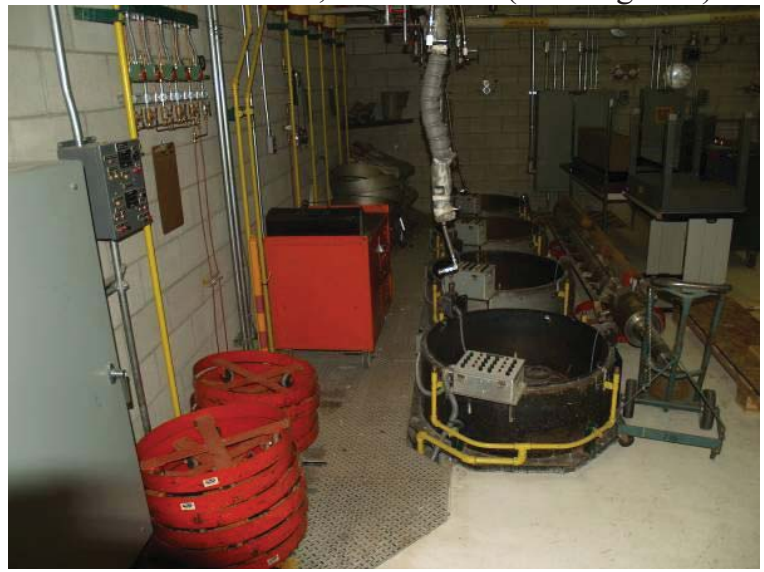

P1015390

MET-L-X Fire Suppression Bottles

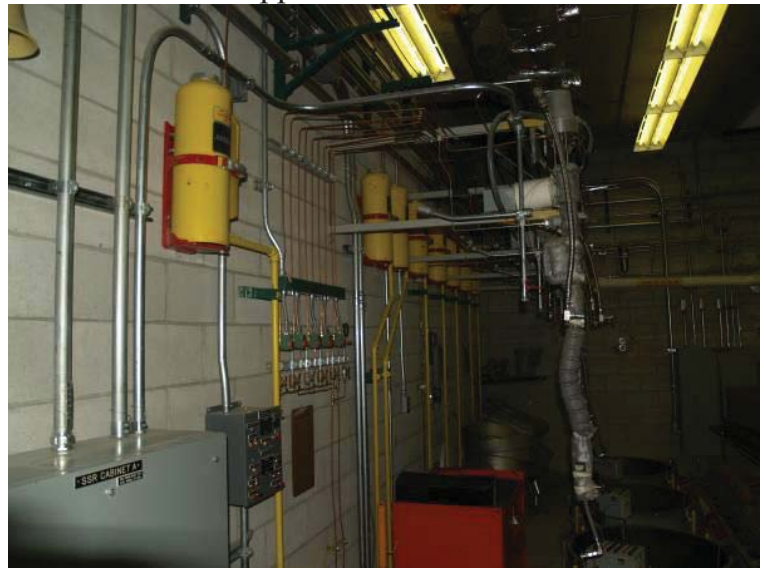


P1015391

Closeup of Inductive Heating System/Fire Suppression Nozzles (4 per station), Manifold B

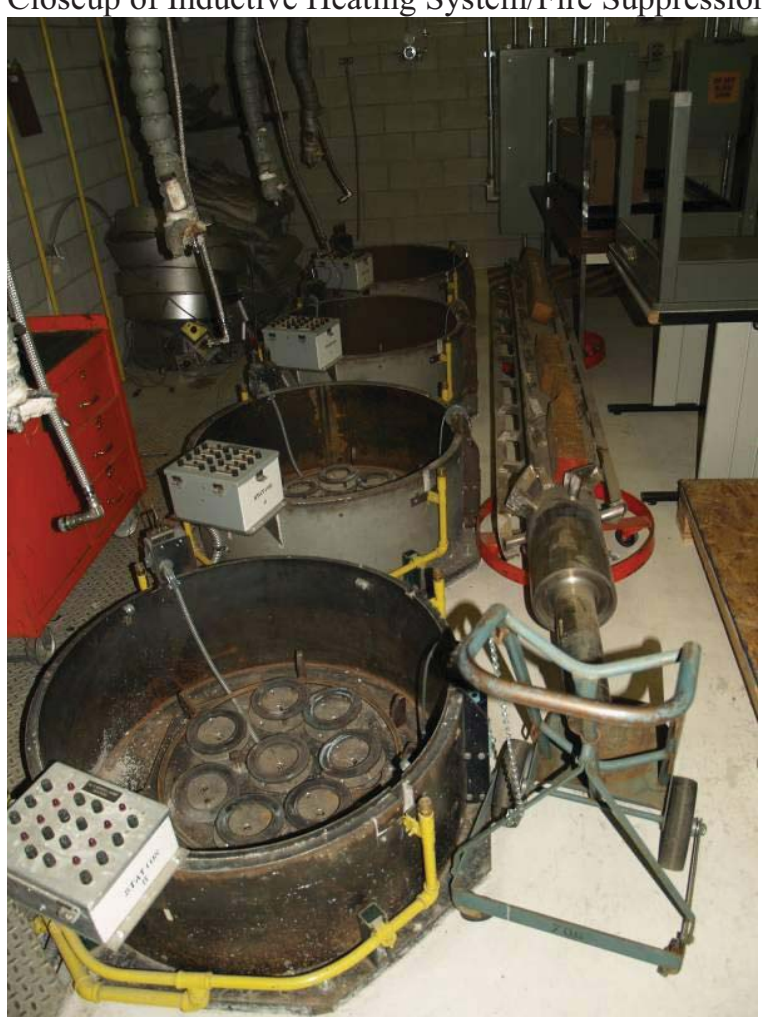

P1015392
Manifold B Piping for Nitrogen Vacuum Systems

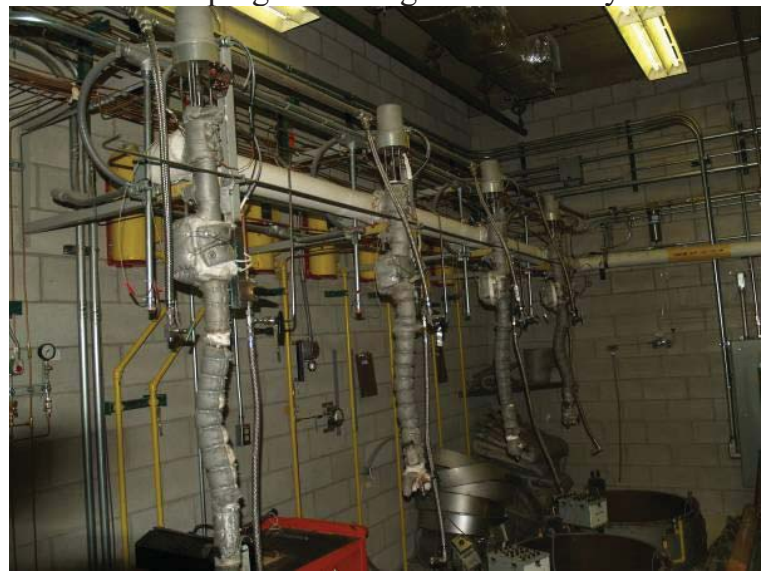


P1015393

SSR Cabinets/Low Oxygen Alarm/Sodium Piping/Storage Miscellaneous Items

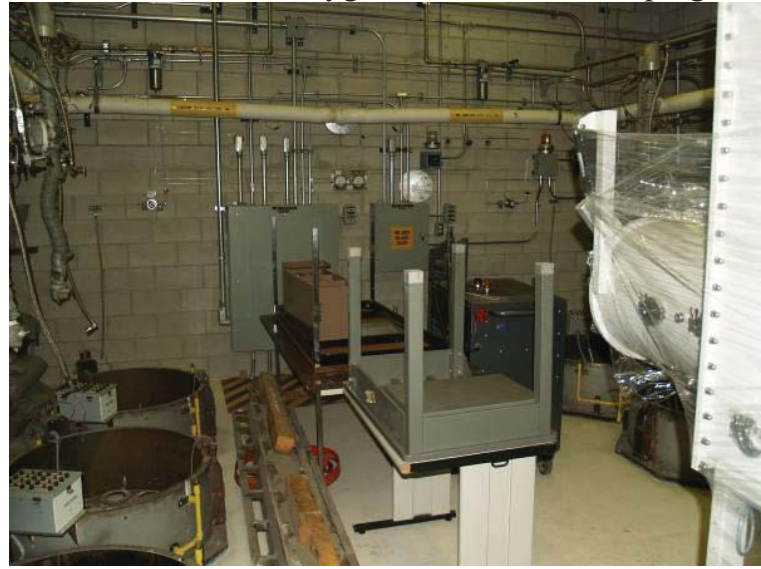

P1015394

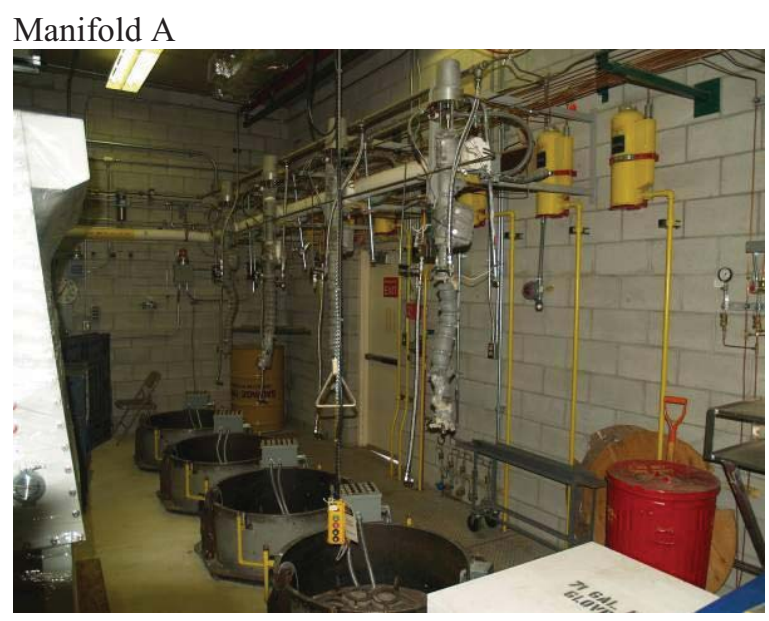

P1015395

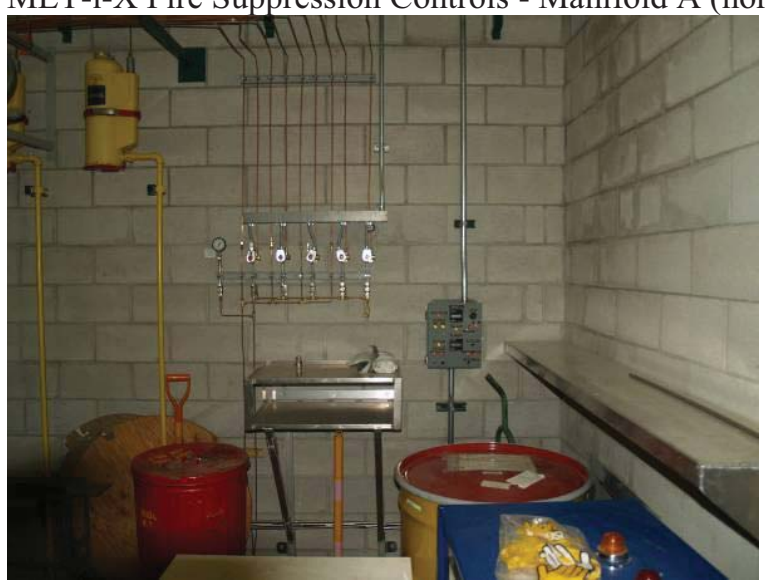


P1015396

MET-1-X Fire Suppression Controls - Manifold B (south wall)

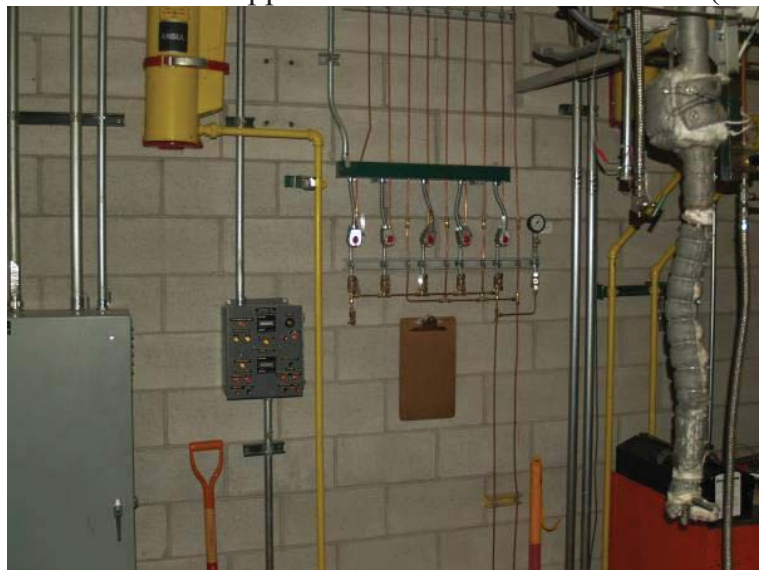

P1015397

P1015398

New Glove Box for MFC 781 (Being Stored)

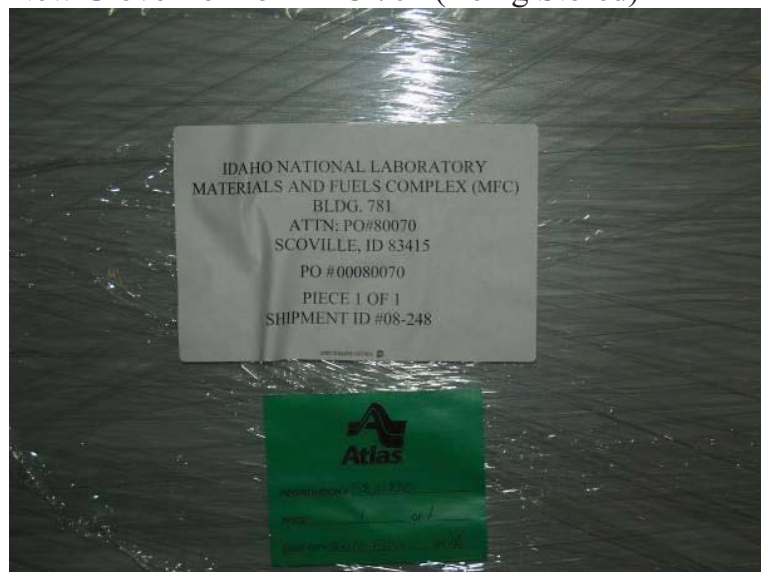

Portable Instrumentation - Counting Ratemeter Model CRM-51M (Manufactured by NMC)

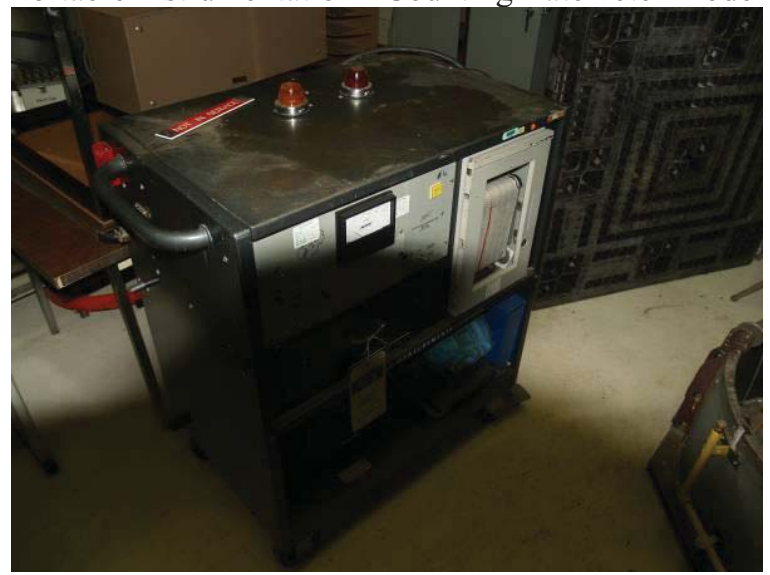


P1015399

Barrel Heating Belts/Blankets - Southeast Corner

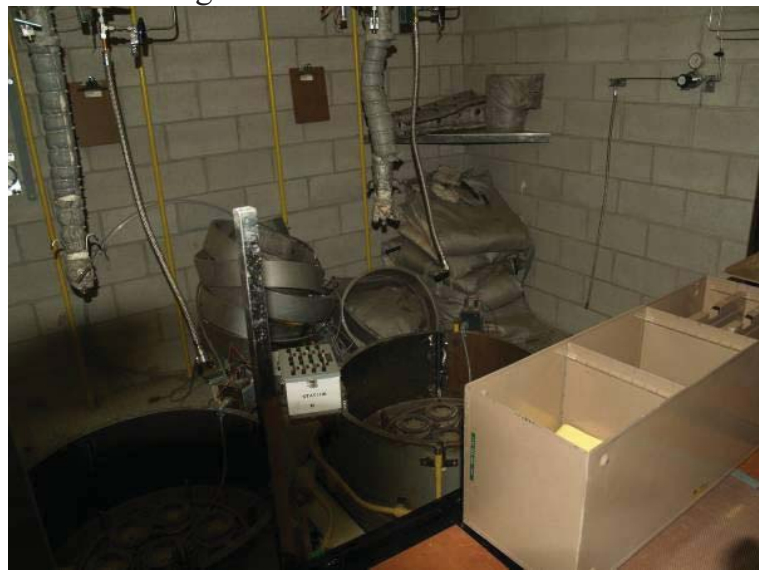

P1015400

Portable Instrumentation - Counting Ratemeter Model CRM-51M (Manufactured by NMC) on west wall

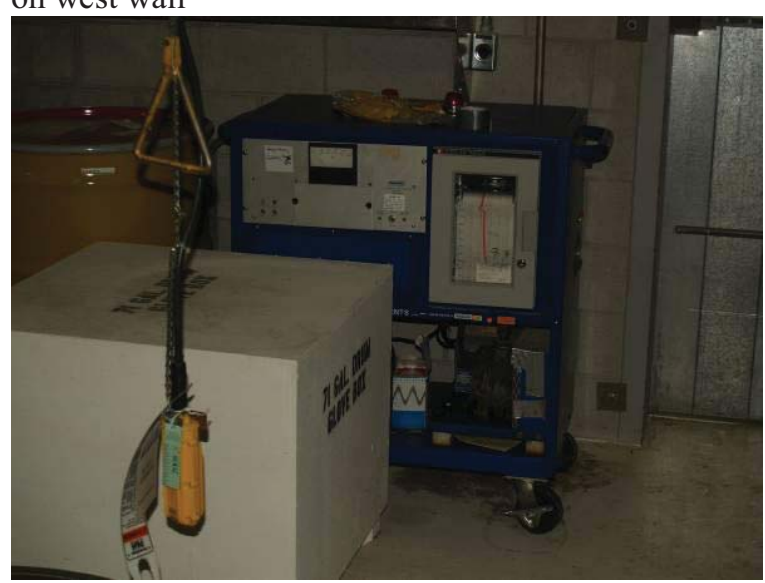


P1015401

Upper View of Nitrogen Feed and Sodium Drain System

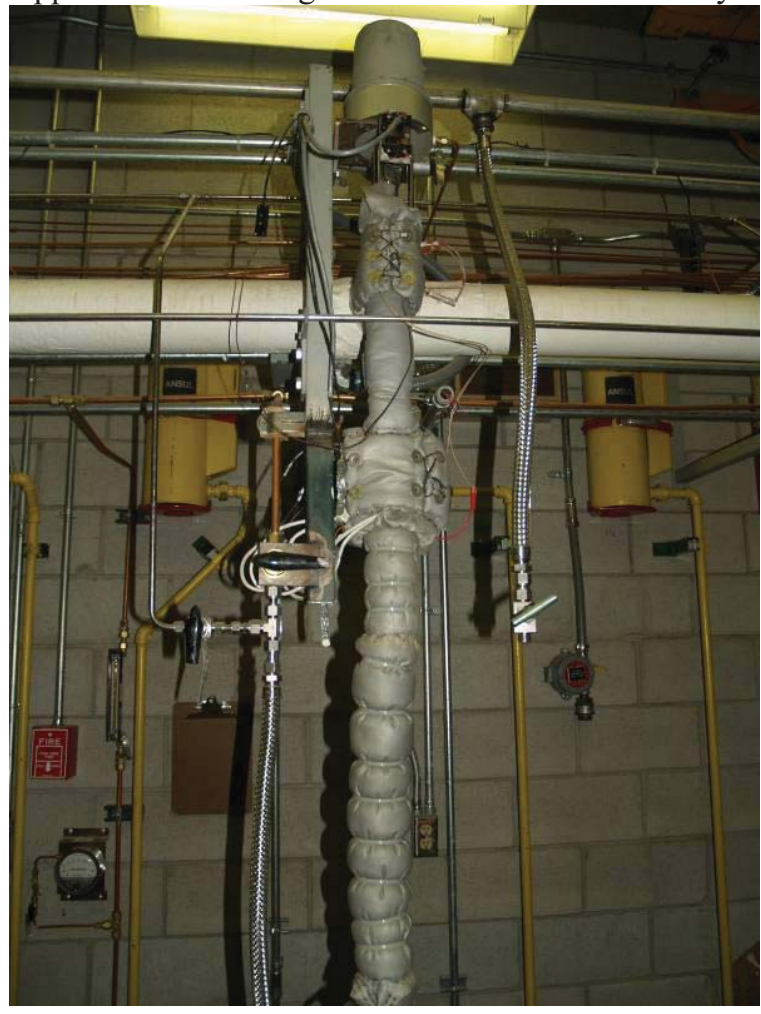

P1015402 Lower View of Nitrogen Feed and Sodium Drain System/Barrel Heater Assembly Manifold A

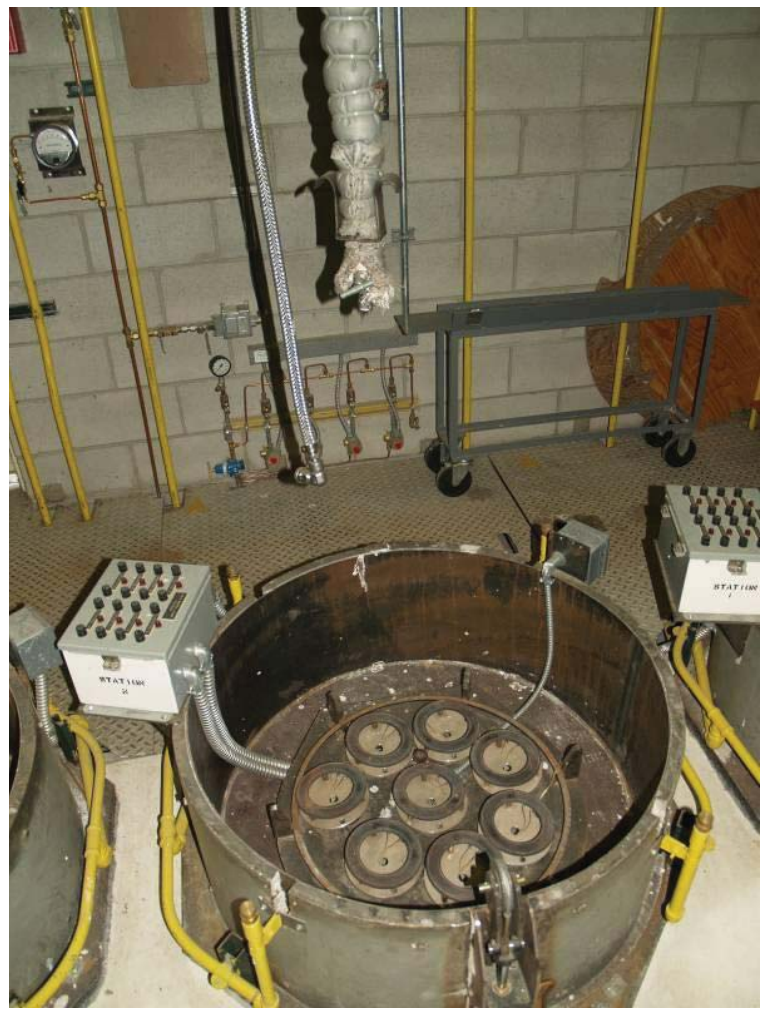


P1015403

New Glovebox for MFC-781 (Being Stored)

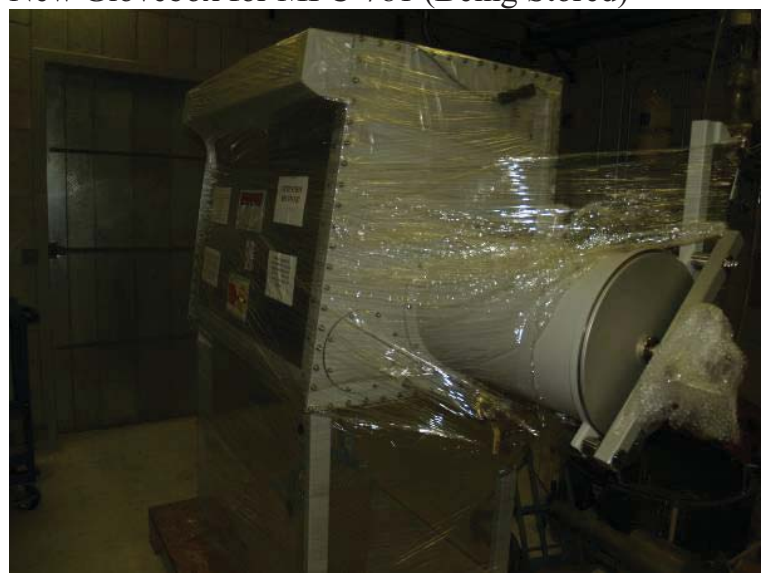

P1015447

P\&H Beta HEVI-LIFT 1/2-Ton Overhead Gantry Crane System

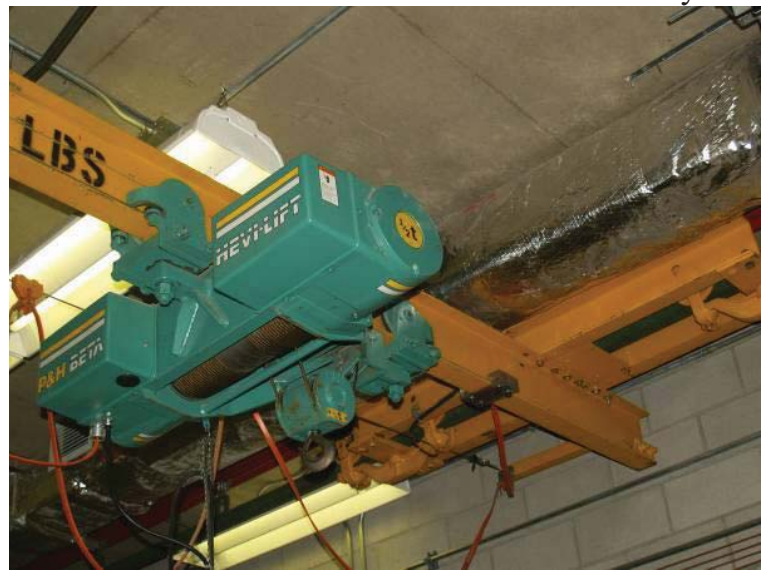

P1015448

P\&H Beta HEVI-LIFT 1/2-Ton Overhead Gantry Crane System

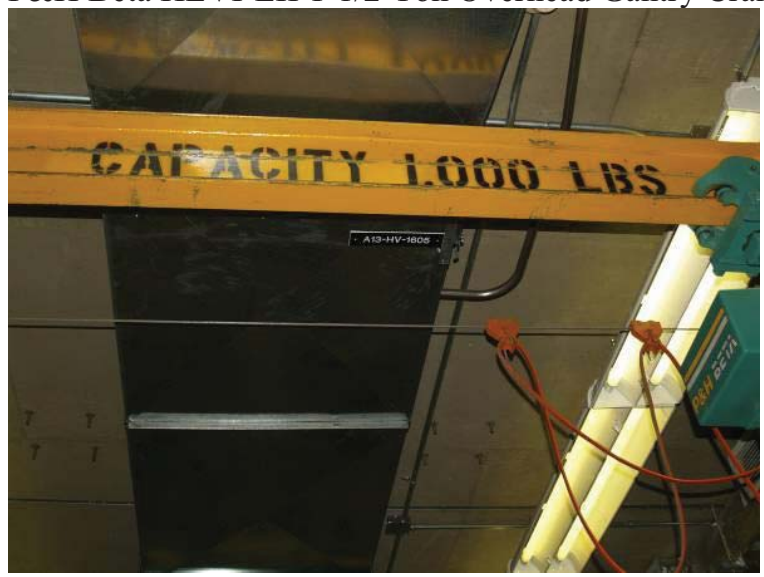


P1015449

P1015450

P1015451
P\&H Beta HEVI-LIFT 1/2-Ton Overhead Gantry Crane System

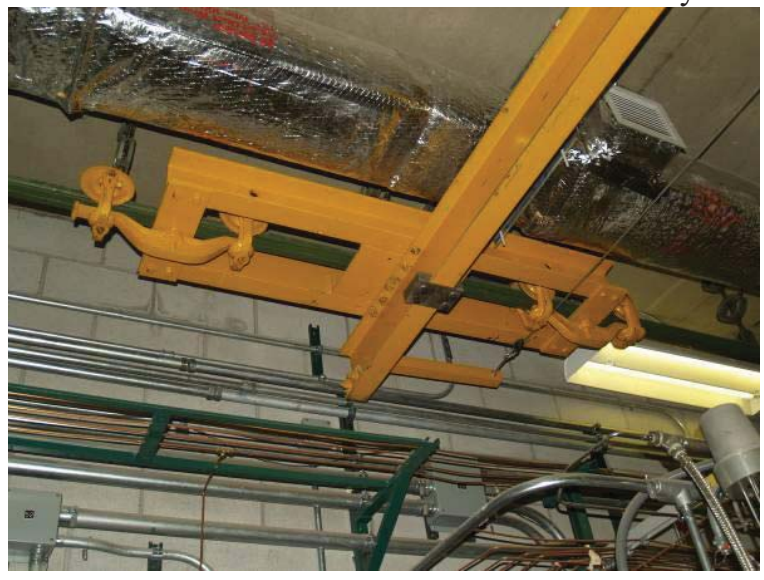

Larger View P\&H Beta HEVI-LIFT 1/2-Ton Overhead Gantry Crane System/HVAC Ducting

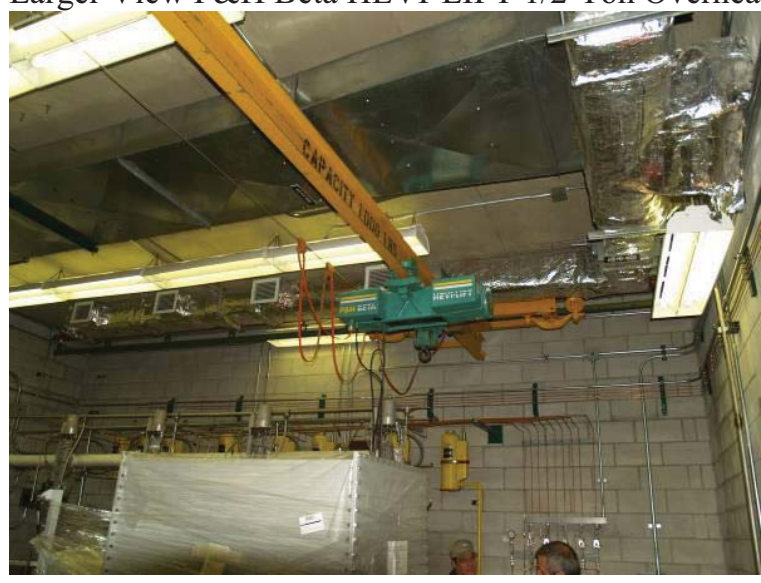

Larger View P\&H Beta HEVI-LIFT 1/2-Ton Overhead Gantry Crane System/HVAC Ducting

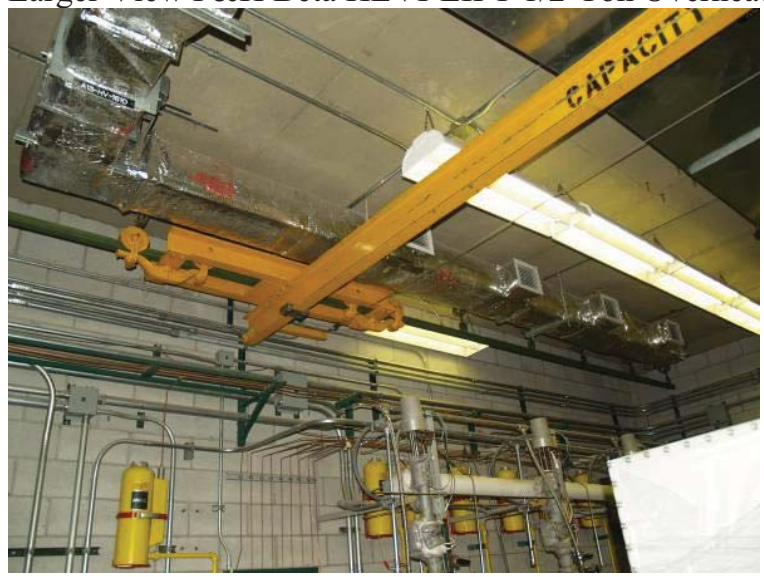


Sodium Processing Facility MFC-799 - Sodium Reaction Area

P1015404

Emergency Safety Shower/In-floor Pit and Drain - Inside West Door, North Wall

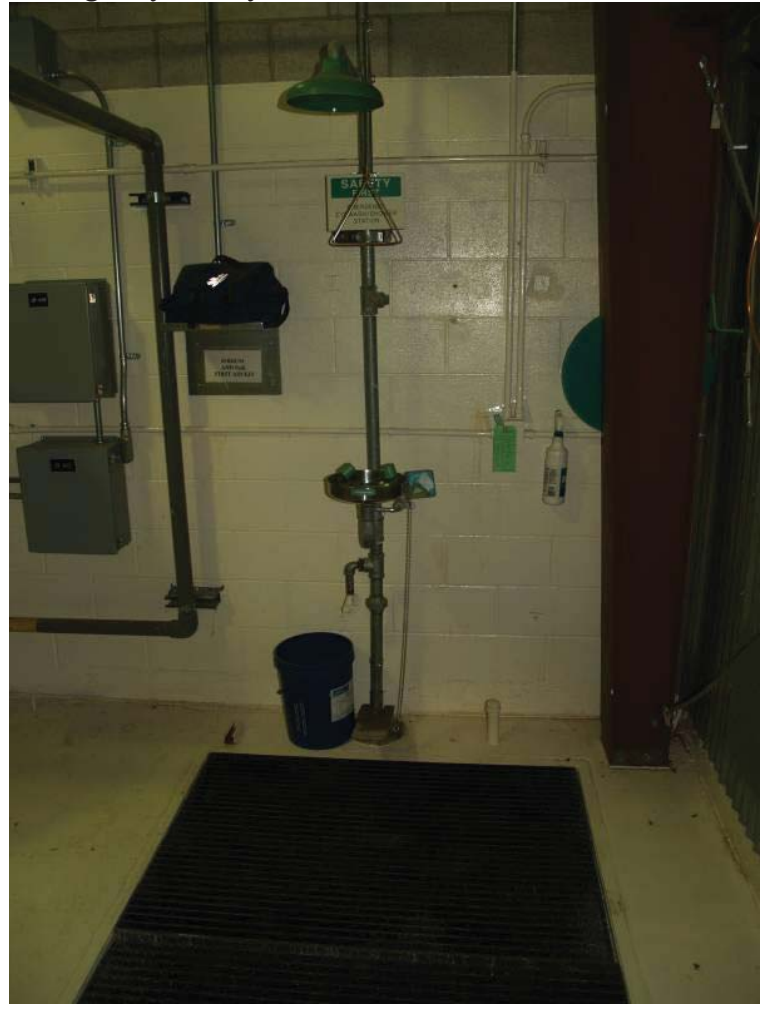

P1015405

500-gal Water Holding Tank

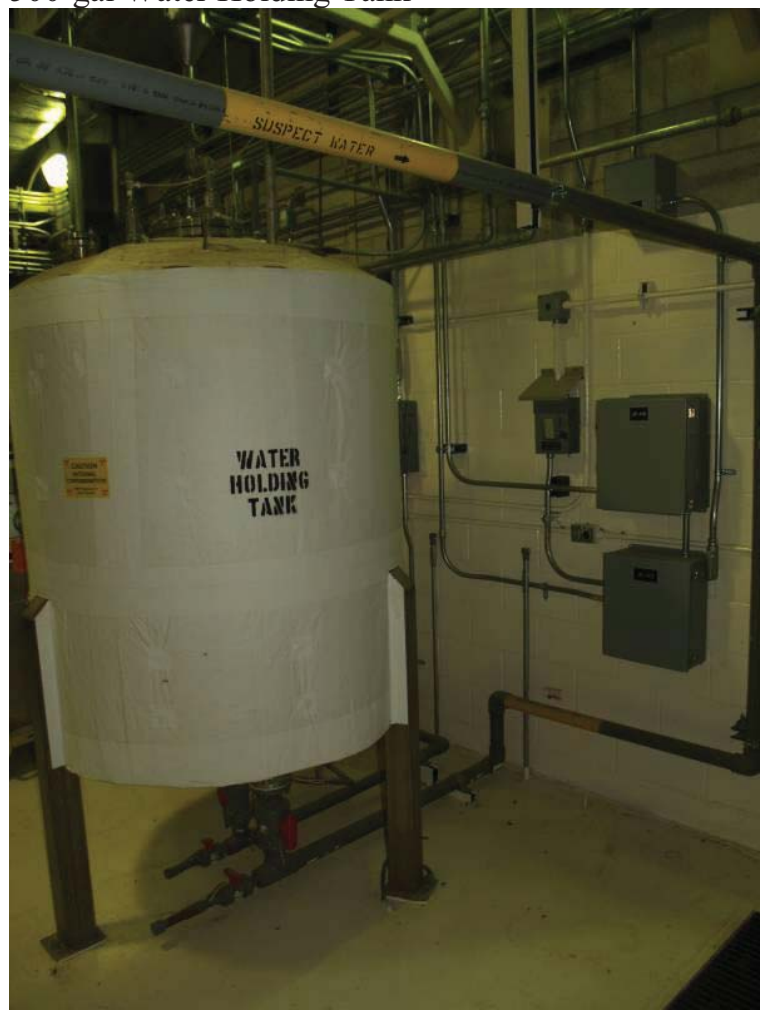


P1015406

Inside West Door, Next to Bioshielding (looking east)

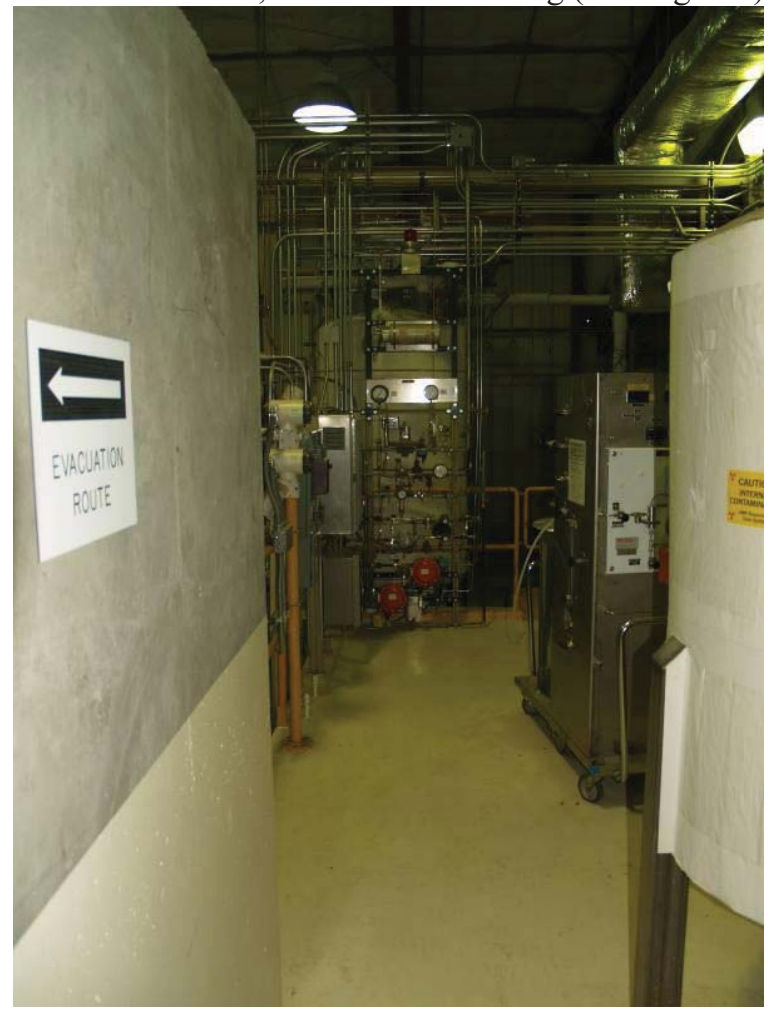

P1015407
Sodium Reactor Vessel (looking southeast)

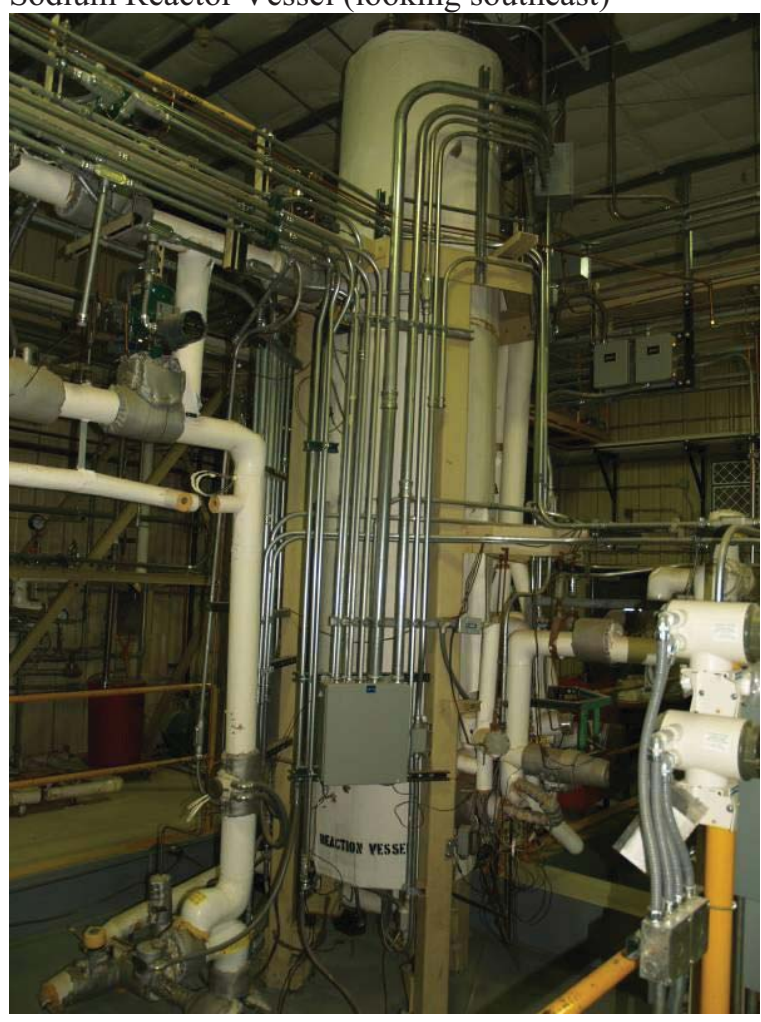


P1015408

Instruments and Controls for Sodium Reactor Vessel

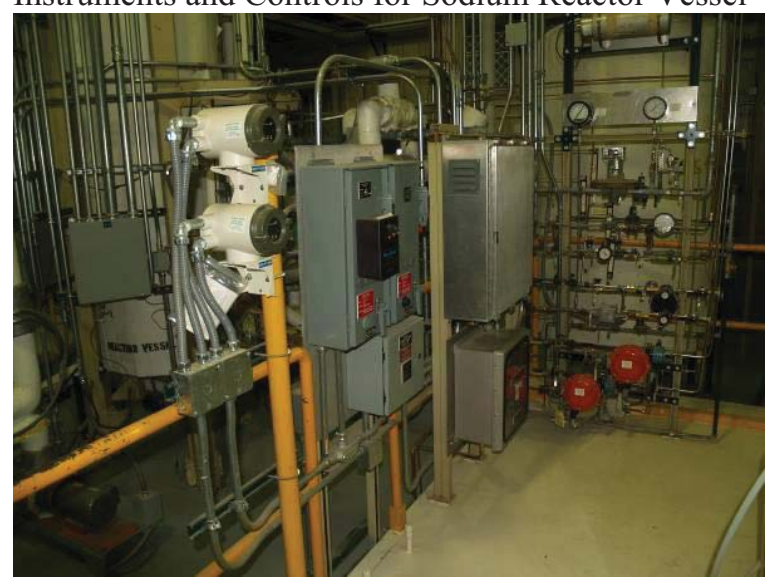

P1015409
Larger View Instruments and Controls for Sodium Reactor Vessel

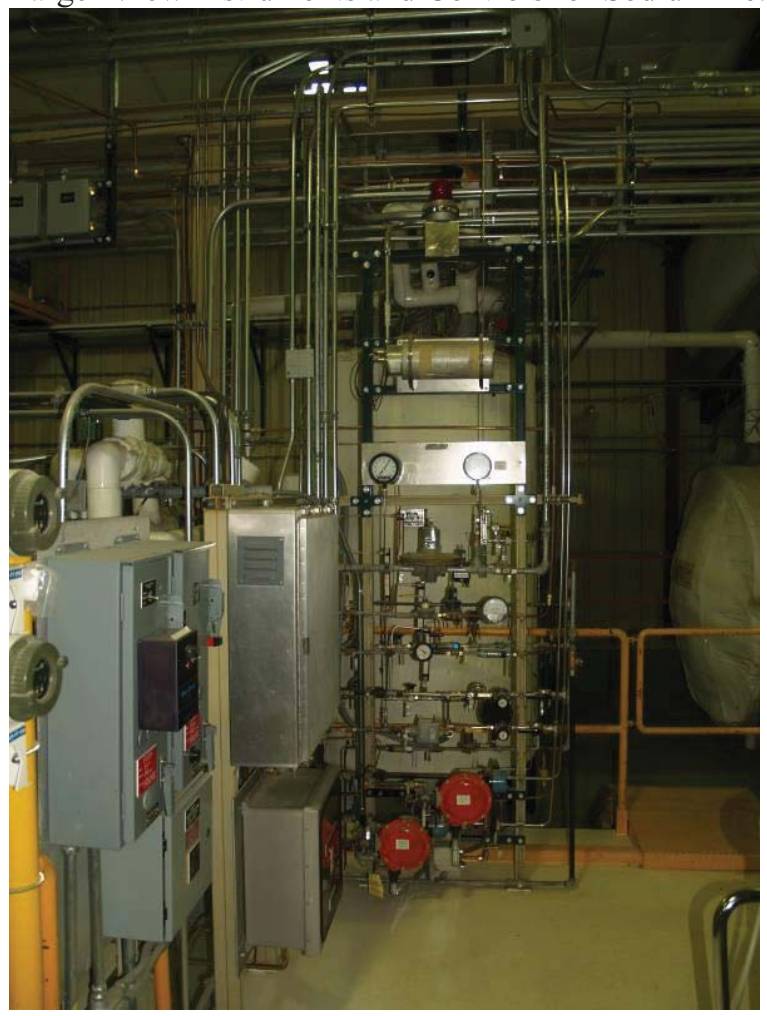


P1015410

Caustic Cooling Tank with Pumps and Pit

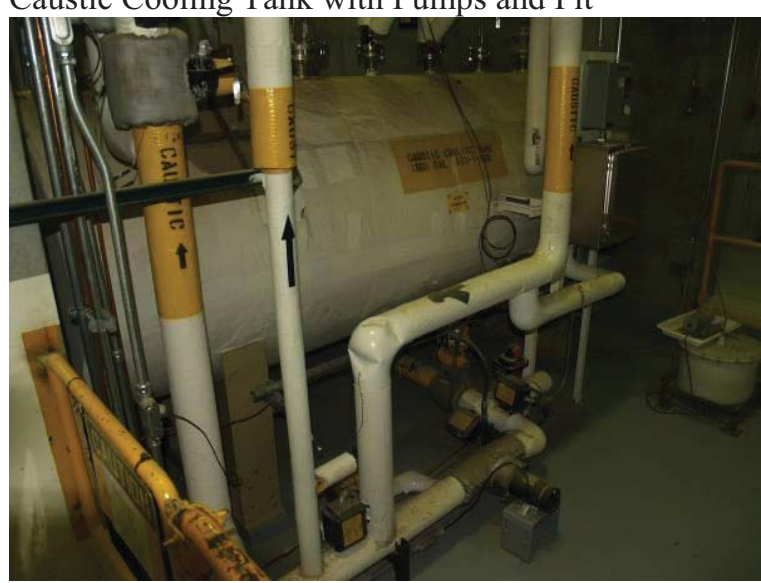

P1015411

Caustic Cooling Tank with Overhead Piping

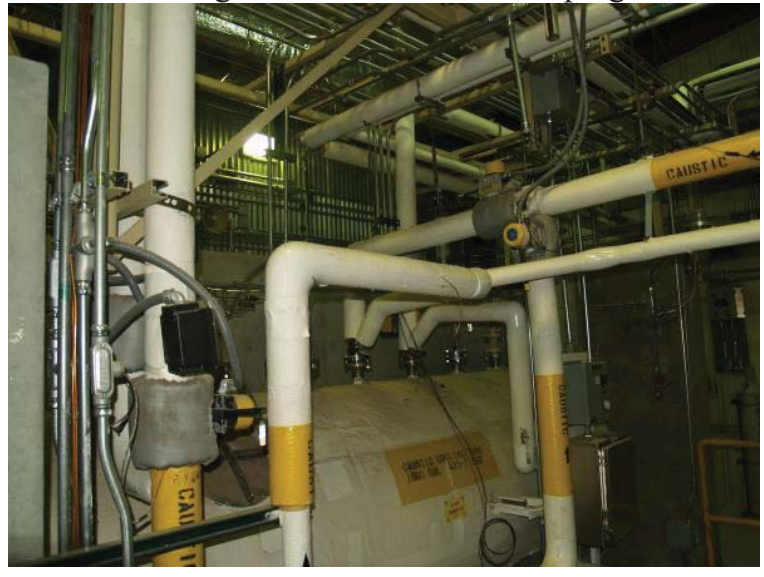

P1015412 Overhead Caustic Piping

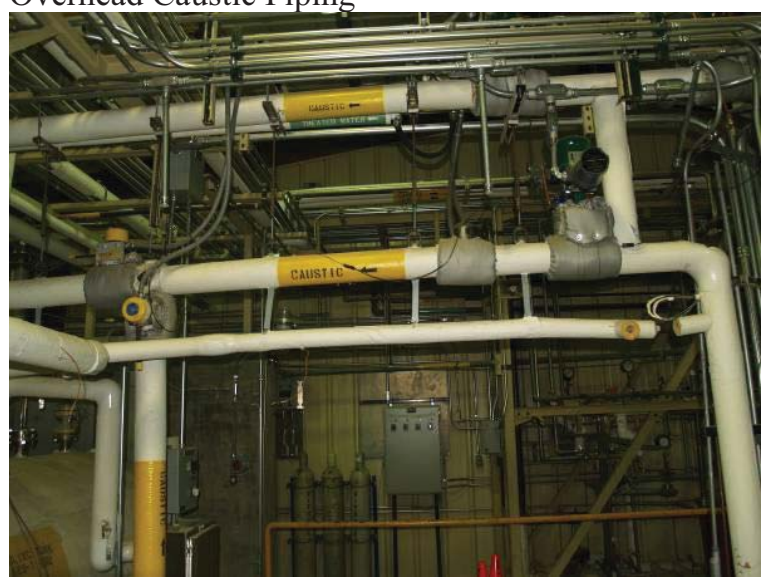


P1015413

Sodium Reactor Vessel/Piping/Instrumentation

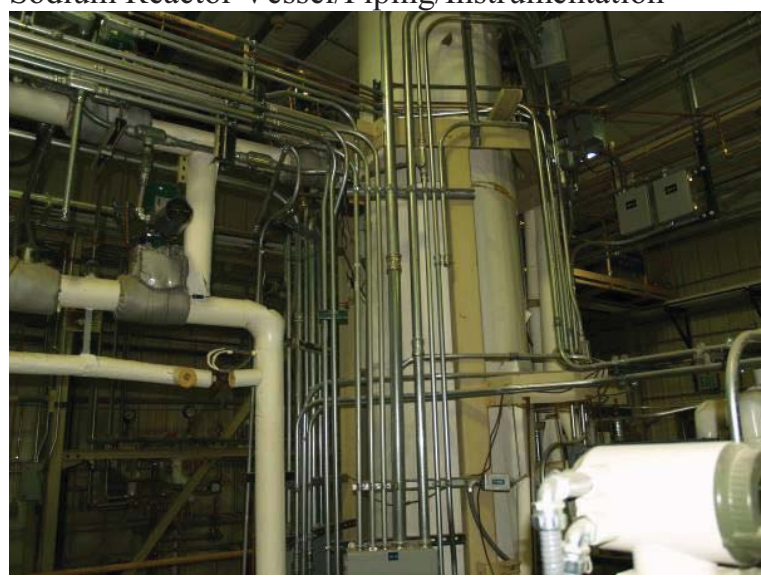

P1015414

Nitrogen Bottles/Control System

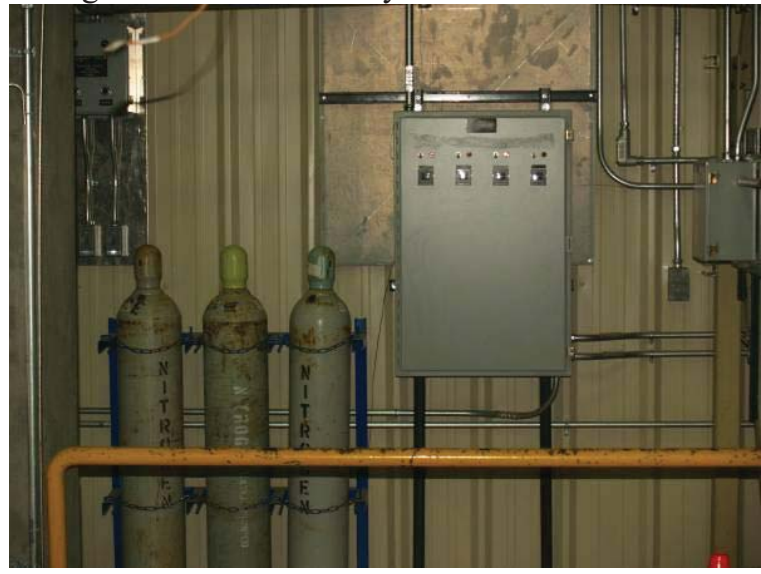

P1015415 Process Water System Piping (70 psig ACTIVE)/Nitrogen Gas Piping

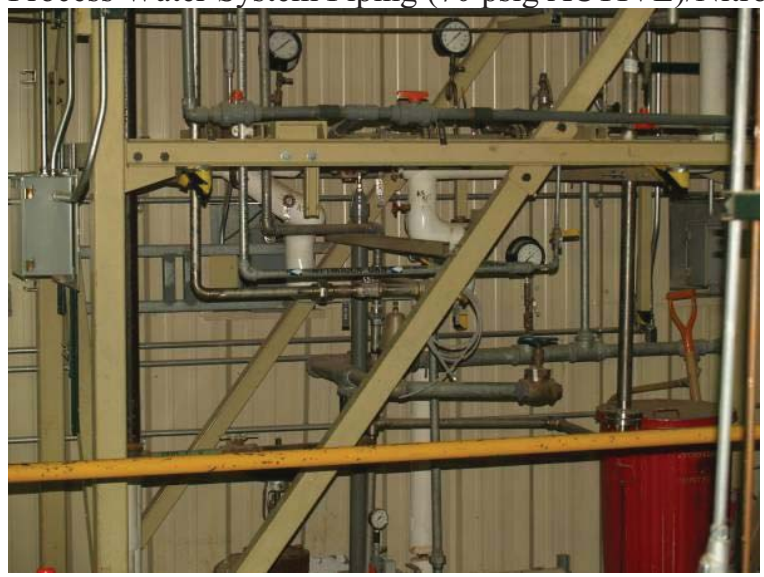


P1015416

Caustic Recirculation Pump for Sodium Reactor Vessel

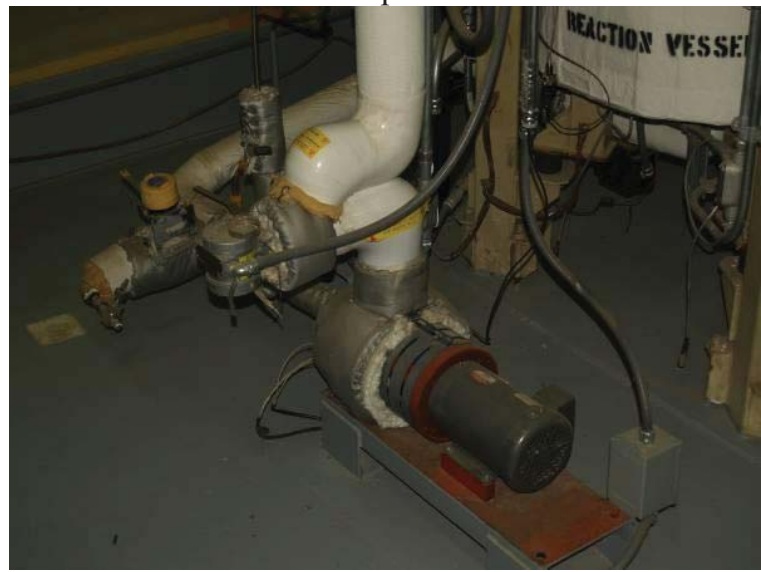

P1015417

Sodium Day Tanks B and A

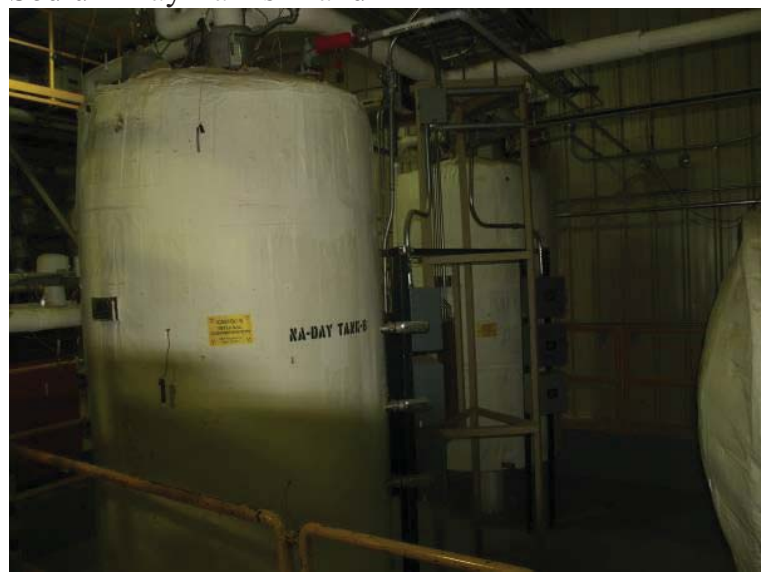

P1015418

Sodium Storage Tank A1-T-101

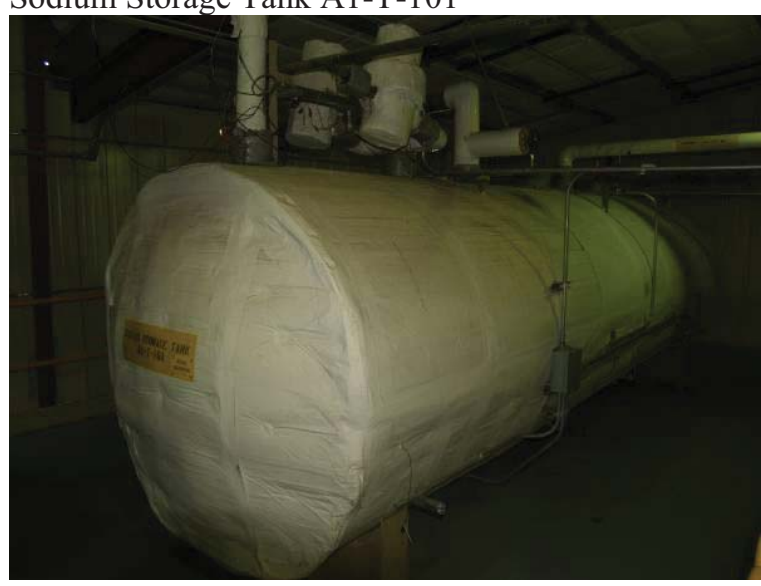


P1015419

P1015420
Sodium Day Tanks Contamination Placard

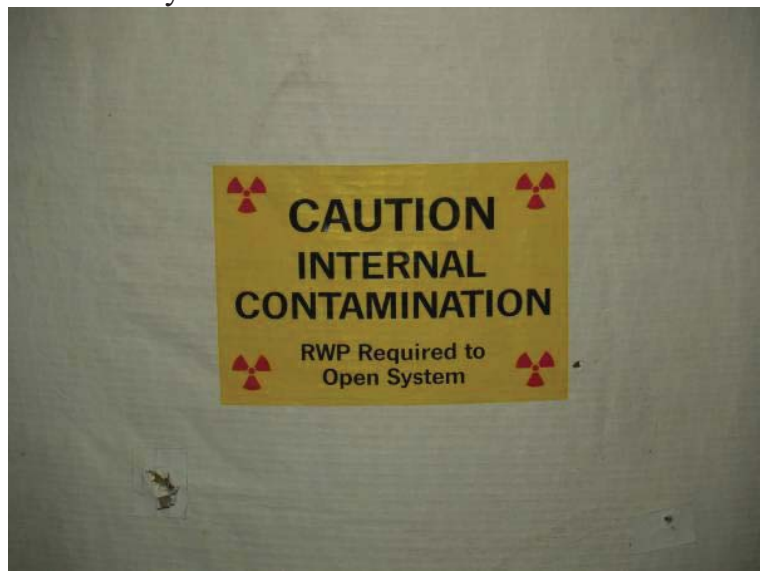

Sodium Storage Tank A1-T-101 Contamination Placard

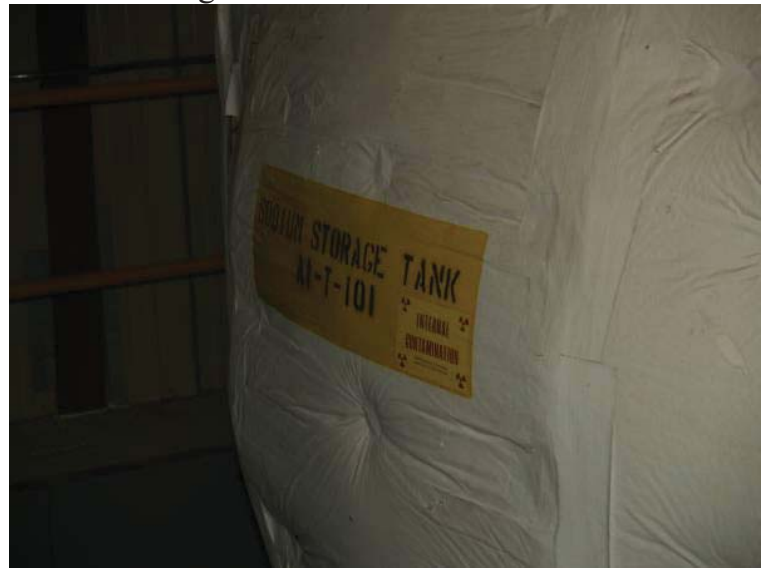


P1015421

P1015422
Heater Control for Sodium Day Tank B

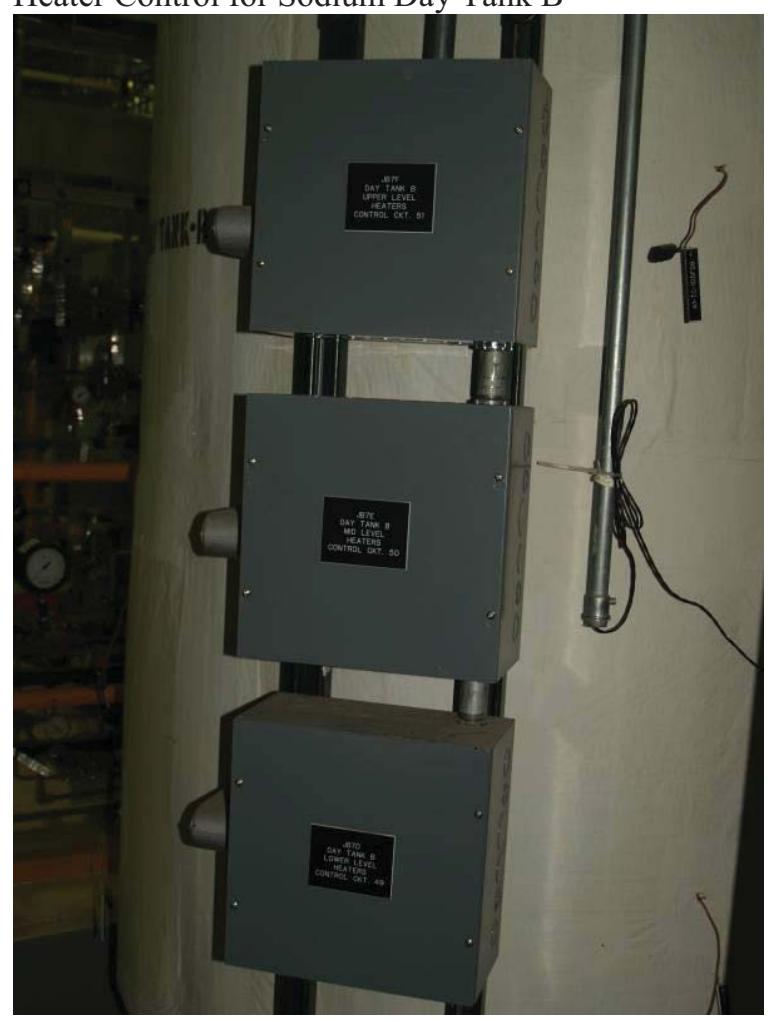

Heater Control for Sodium Day Tank A

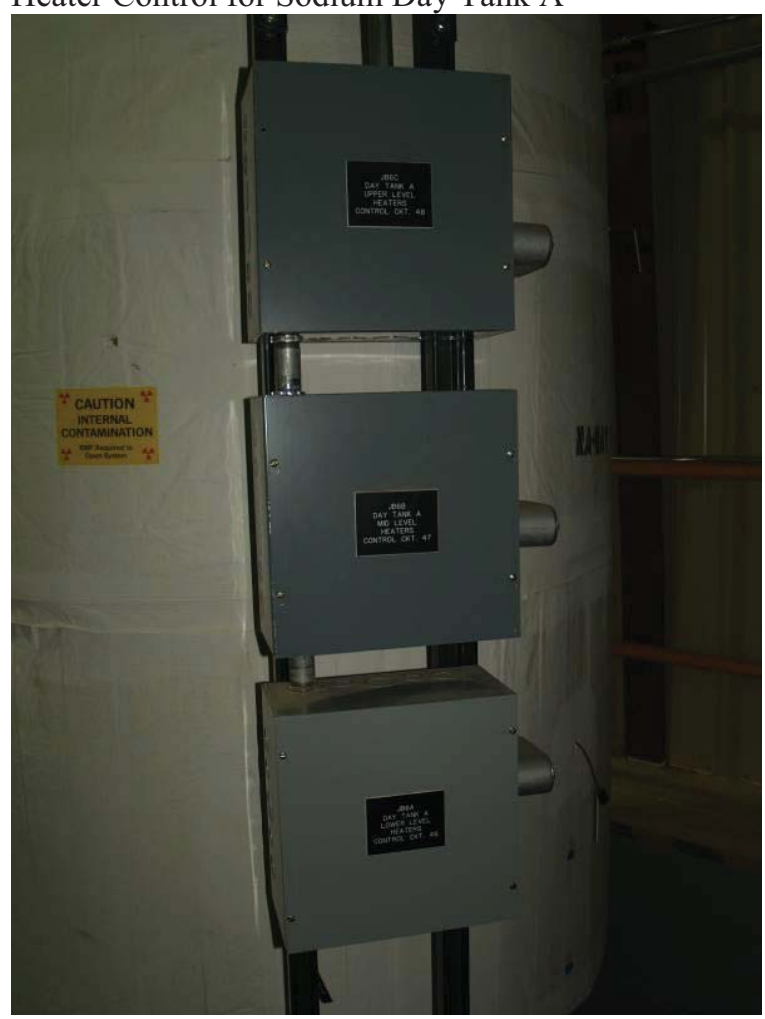


P1015423

Sodium Storage Tank A1-T-101, East Side (looking north)

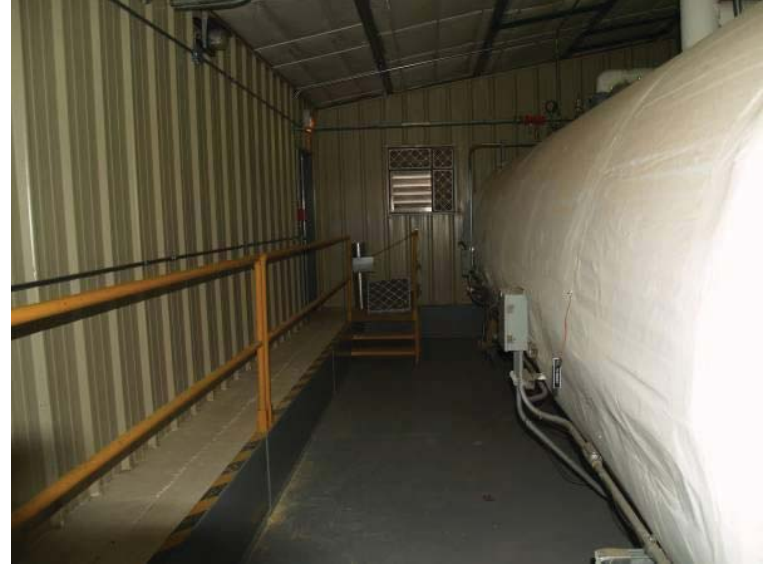

P1015424
Sodium Storage Tank A1-T-101, West Side (looking north)

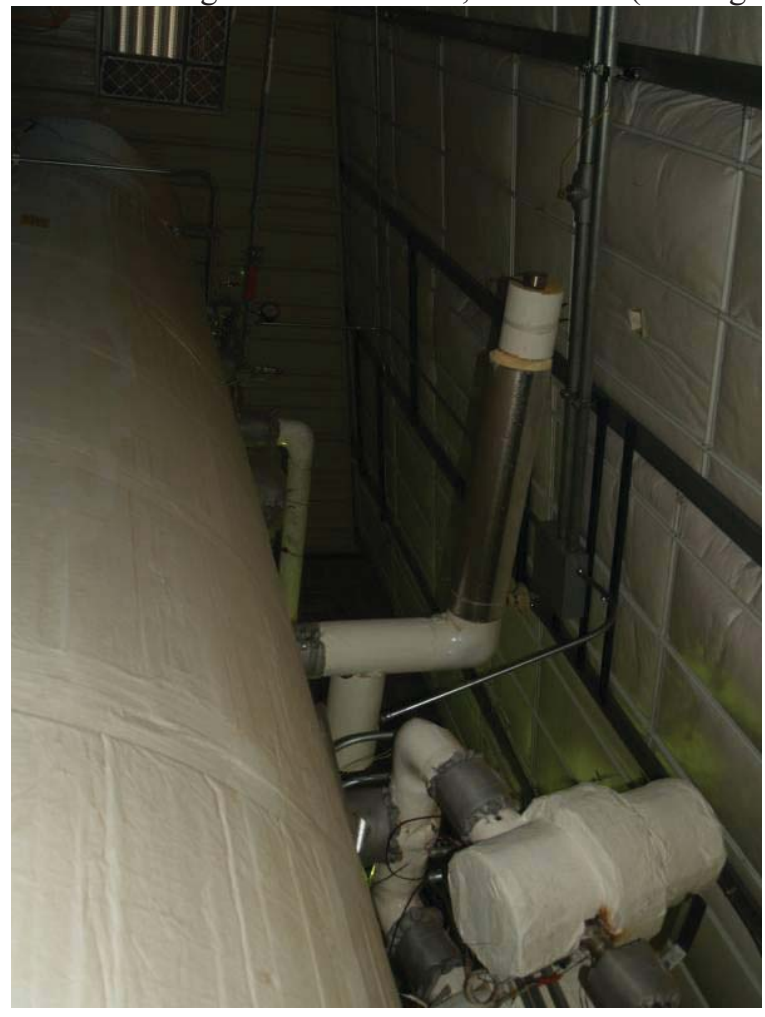


P1015425

P1015426
South Side of Room (looking east)

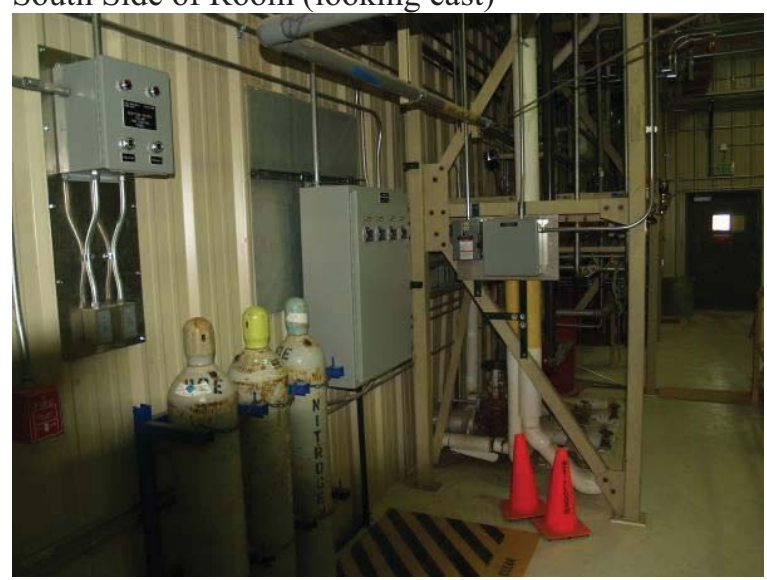

Overhead Utility Piping - south wall

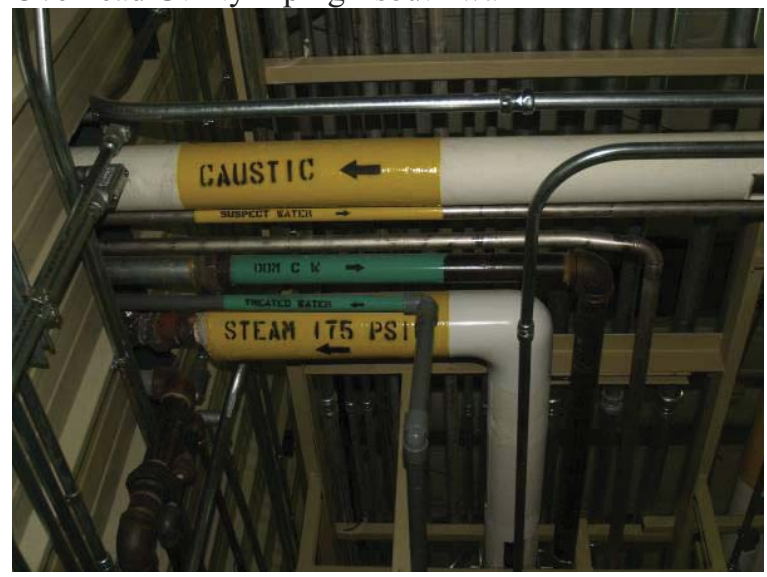


P1015427

Sodium Reactor Vessel (looking northeast)

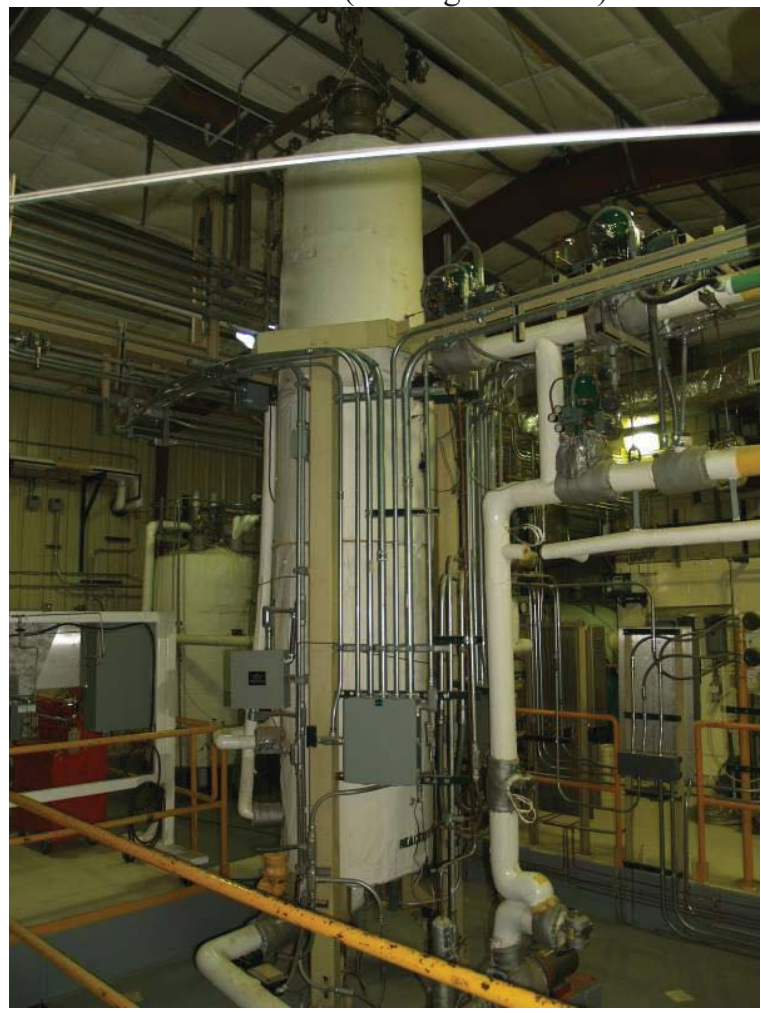

P1015428

Overhead Piping and Valving for Sodium Reactor Vessel

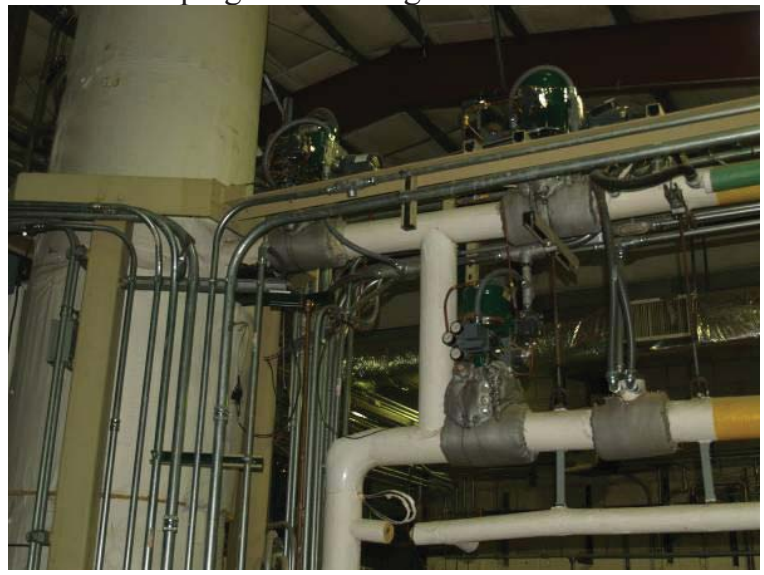


P1015429

Caustic Recirculation Pump for Sodium Reactor Vessel

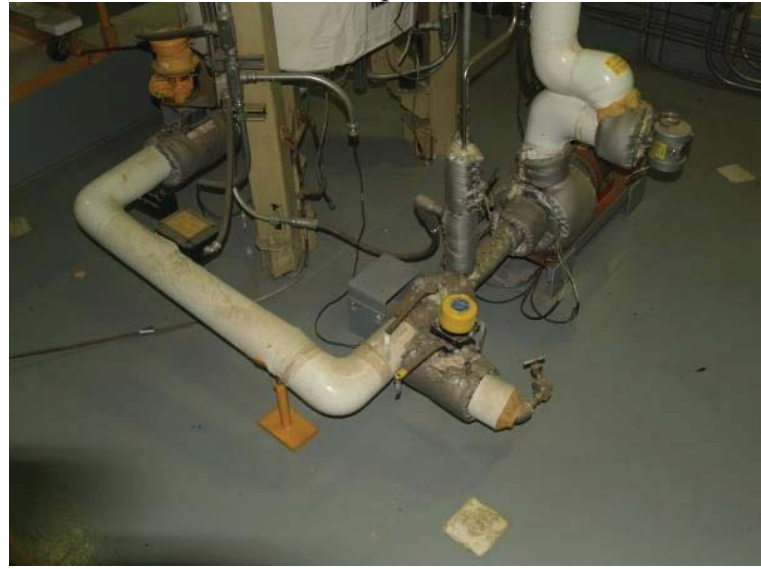

P1015430

P1015431
Caustic Cooling Tank Pump

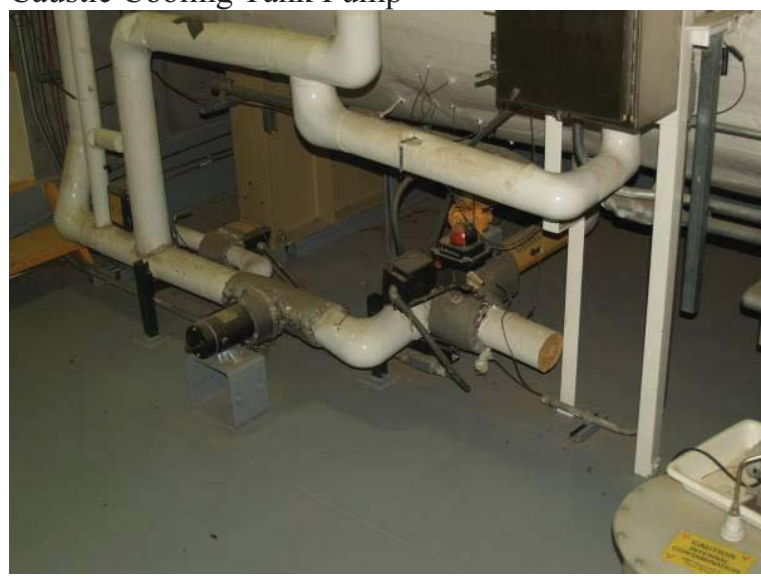

Larger View of Caustic Cooling Tank and Piping

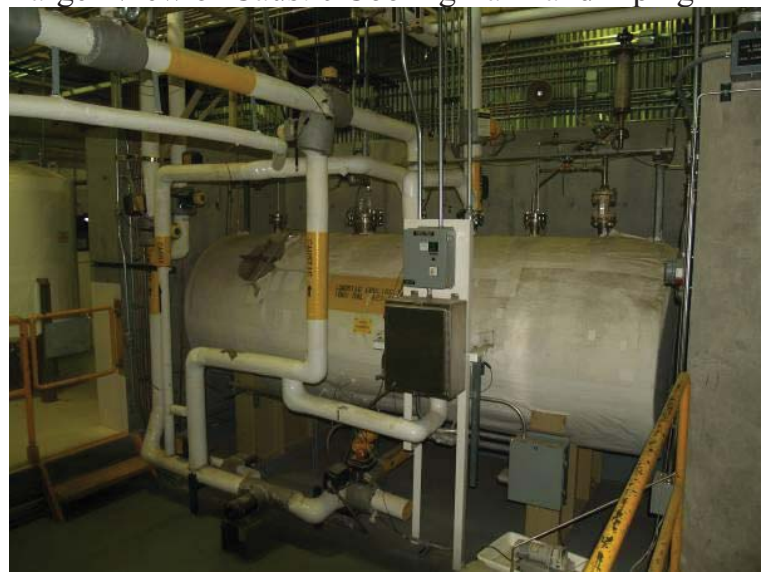


P1015432

Low Oxygen Alarm (Local Alarm 1307)

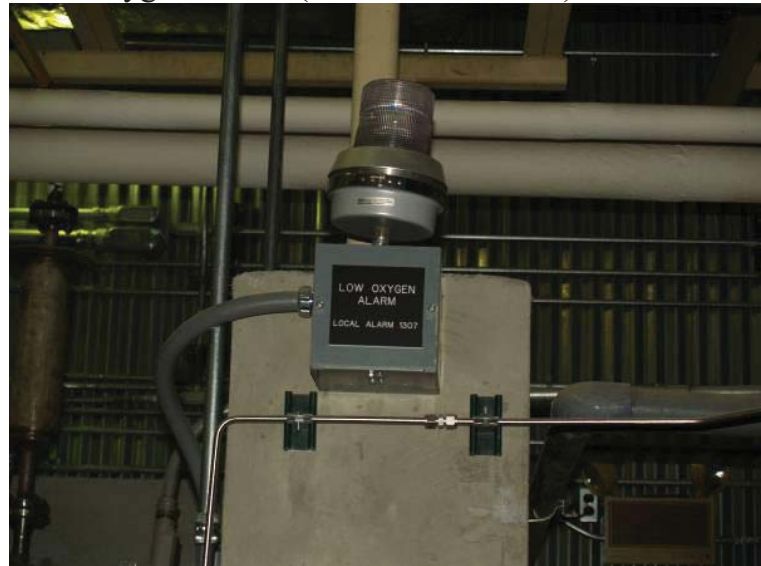

P1015433

Portable Sodium Treatment Instrument and Control Cabinet

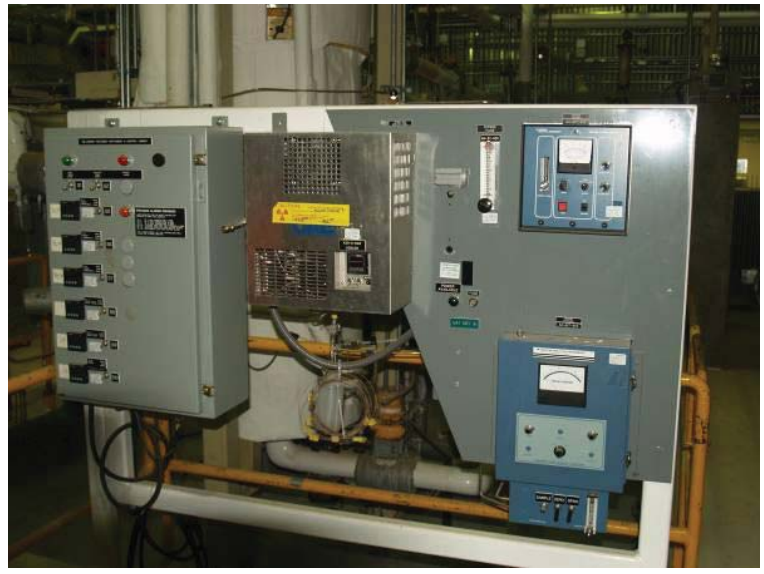

P1015434

Off-gas Piping for Sodium Reactor Vessel

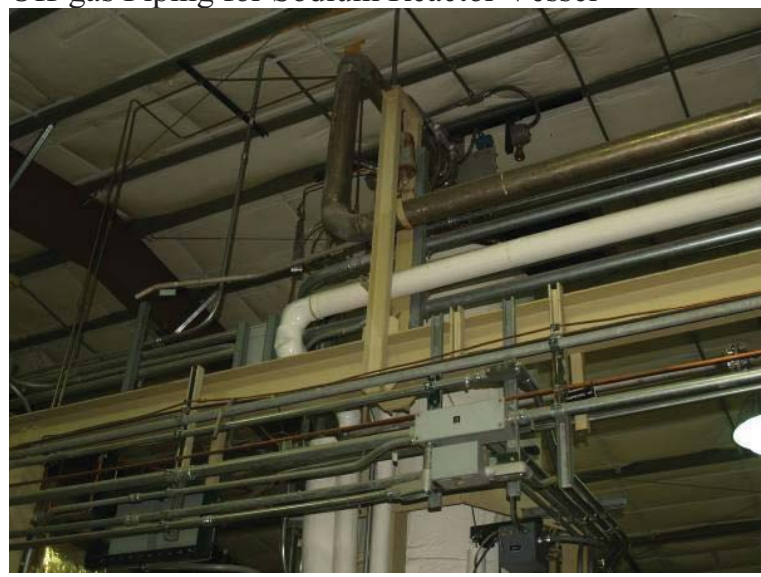


P1015435

Overhead Instrumentation/Power Conduits for Day Tanks

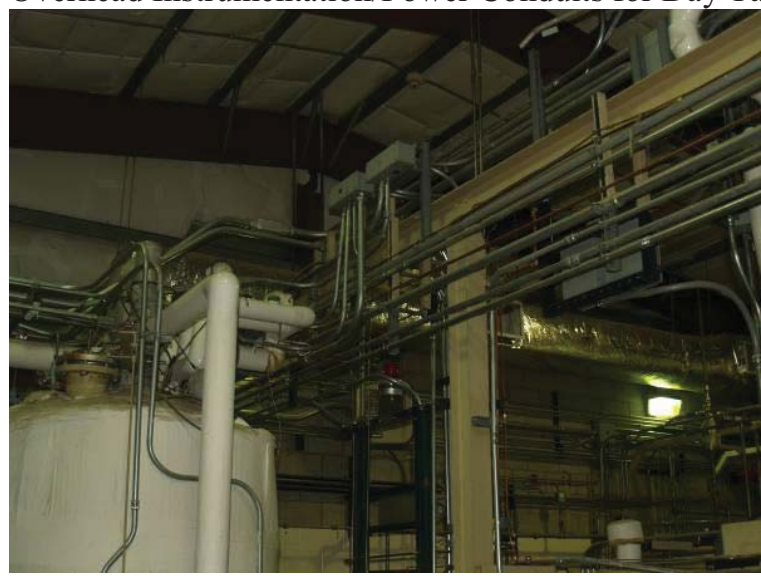

P1015436

P1015437

Overhead Instrumentation/Power Conduits for Day Tank B

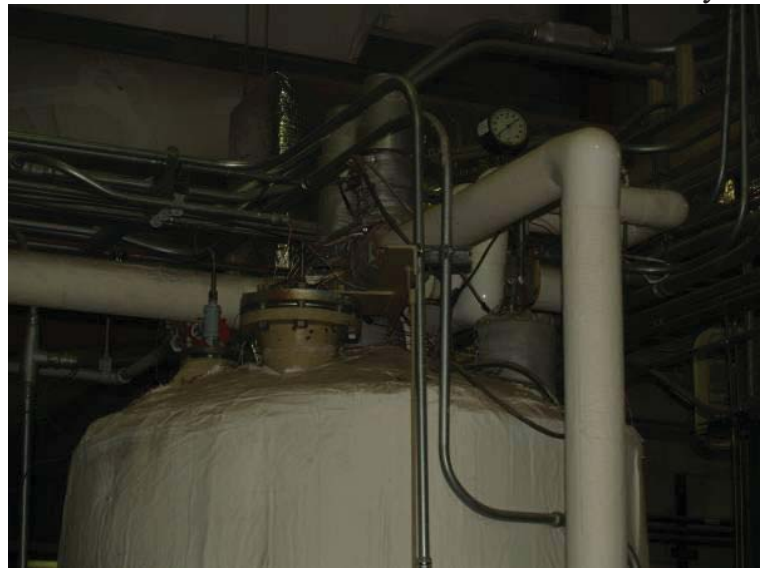

Overhead Instrumentation/Power Conduits for Day Tank A

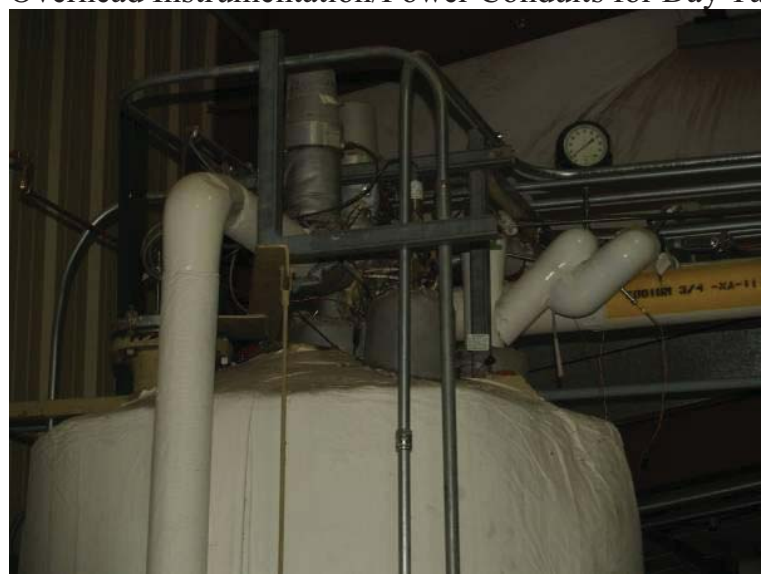


P1015438

Expanded View of Day Tanks A and B and Sodium Storage Tank

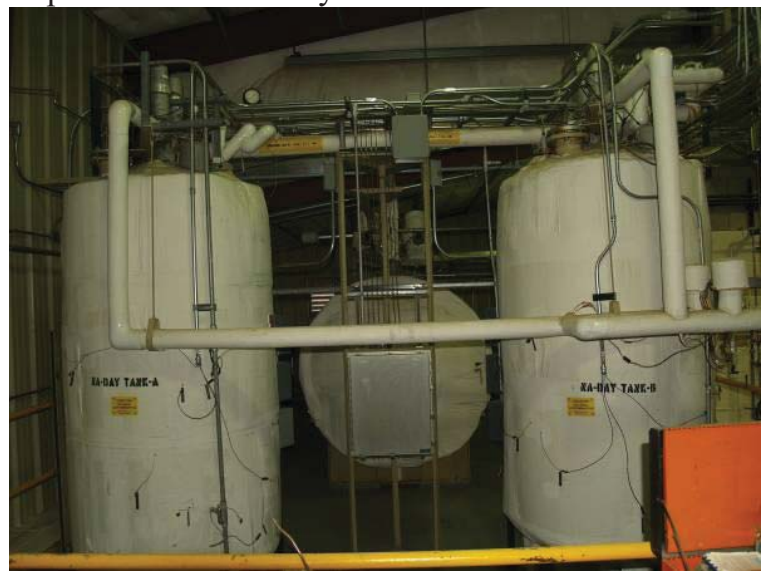

P1015439

P1015440

Oxygen Transmitter A31-LT-1311

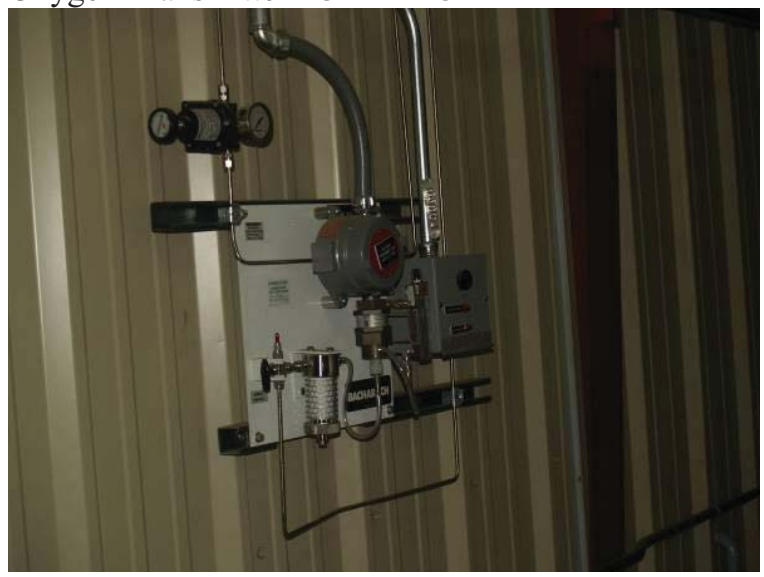

Flanders Pre-Filters for Sodium Reactor Off-gas System (looking south) (Flanders HEPA Filters Directly Above)

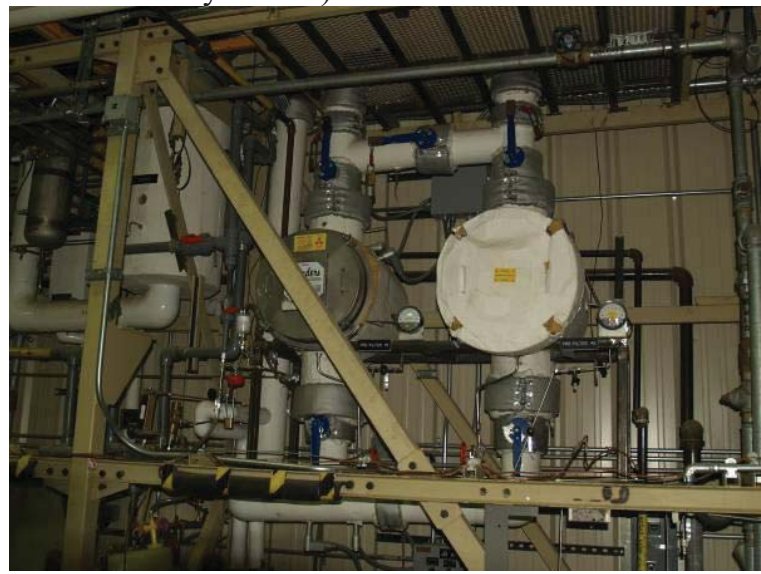


P1015441

Expanded View of South Wall

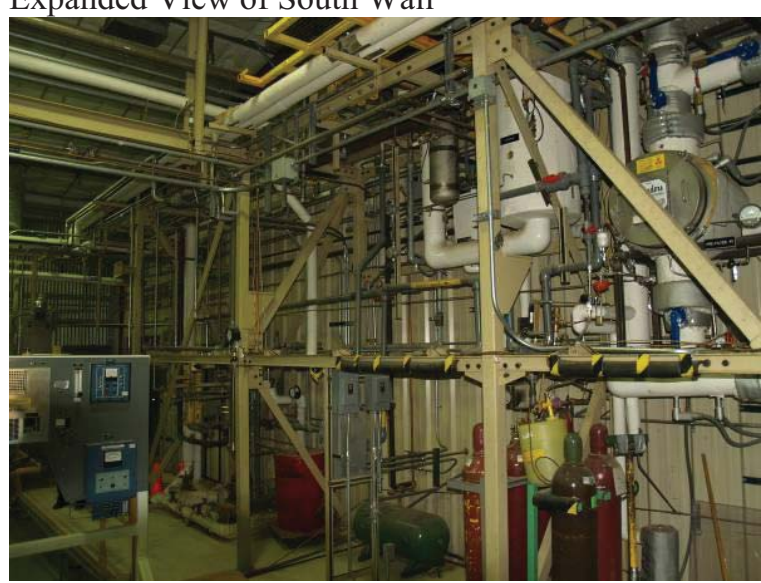

P1015442 Scrubber and Condenser for Sodium Reactor Off-gas System

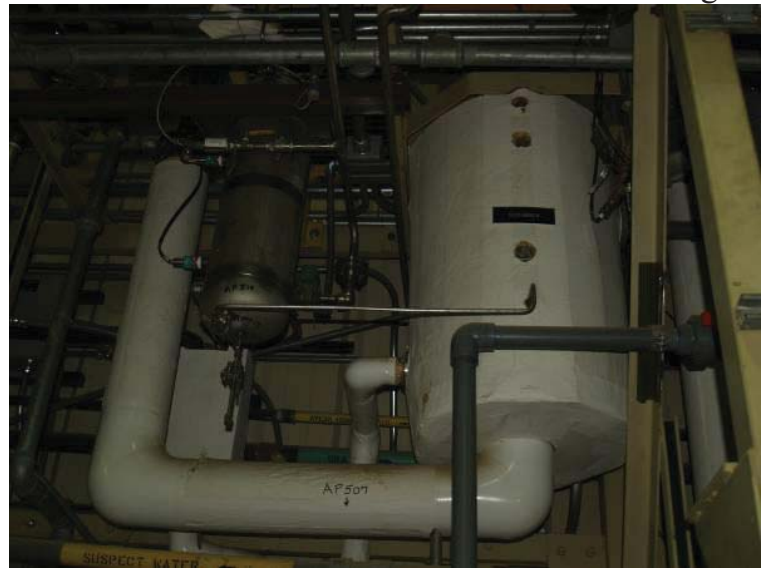

P1015443 Heat Exchanger for Sodium Off-gas System

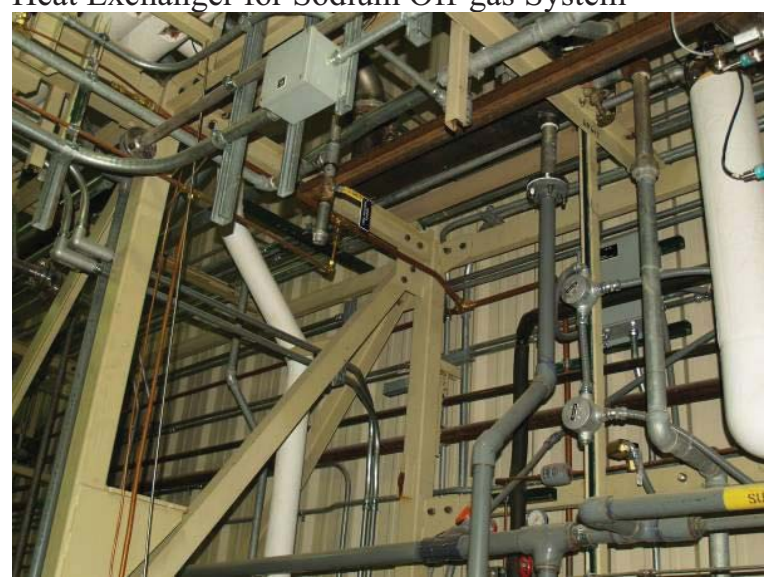


P1015444

Steam and Condensate Return

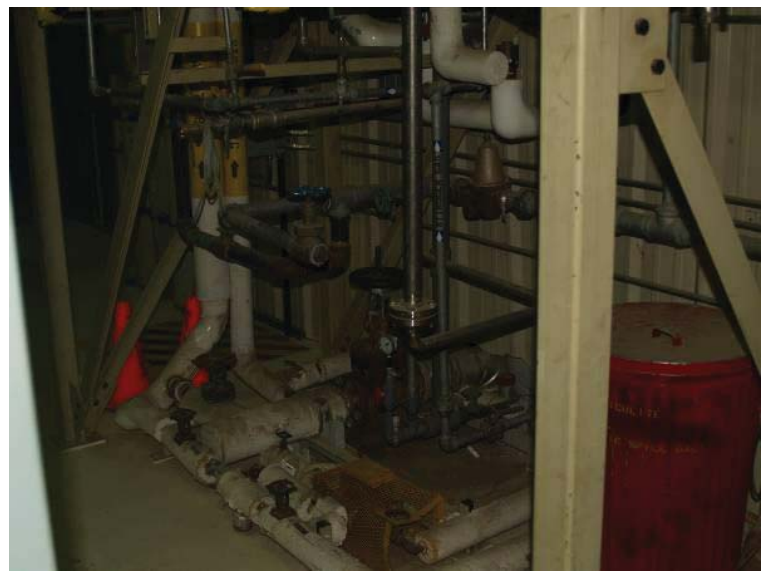


P1015452

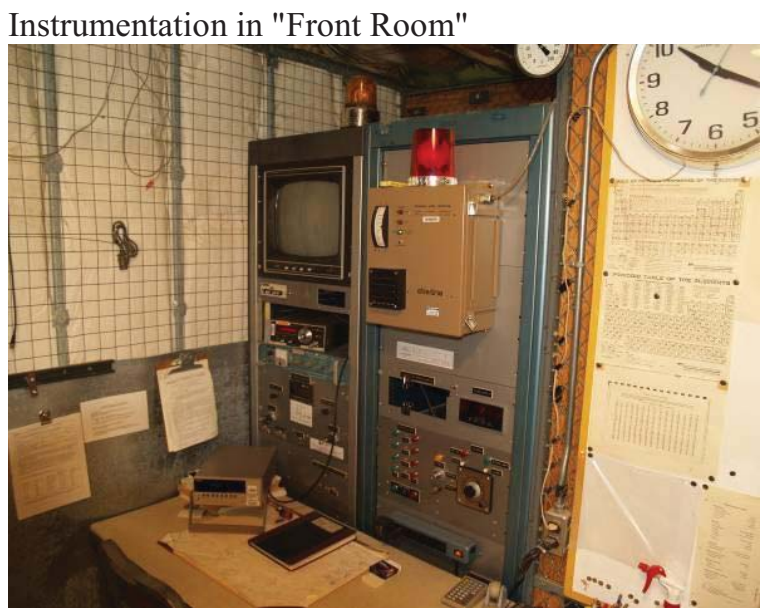

P1015453

Source and Auto Attenuation Device

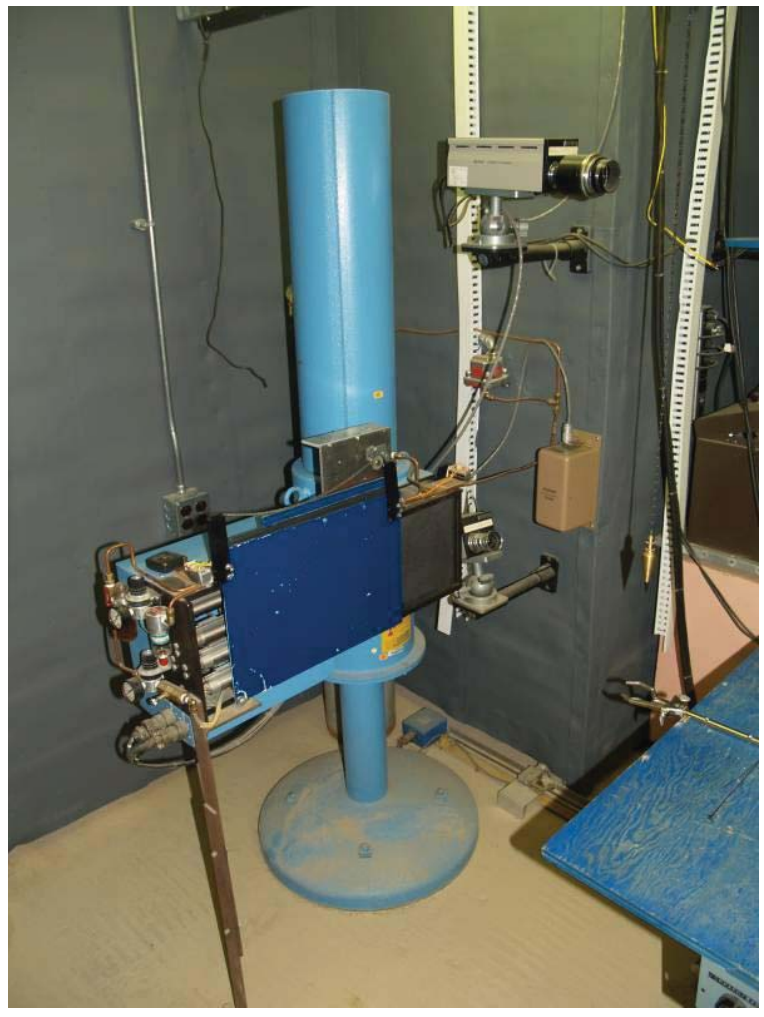




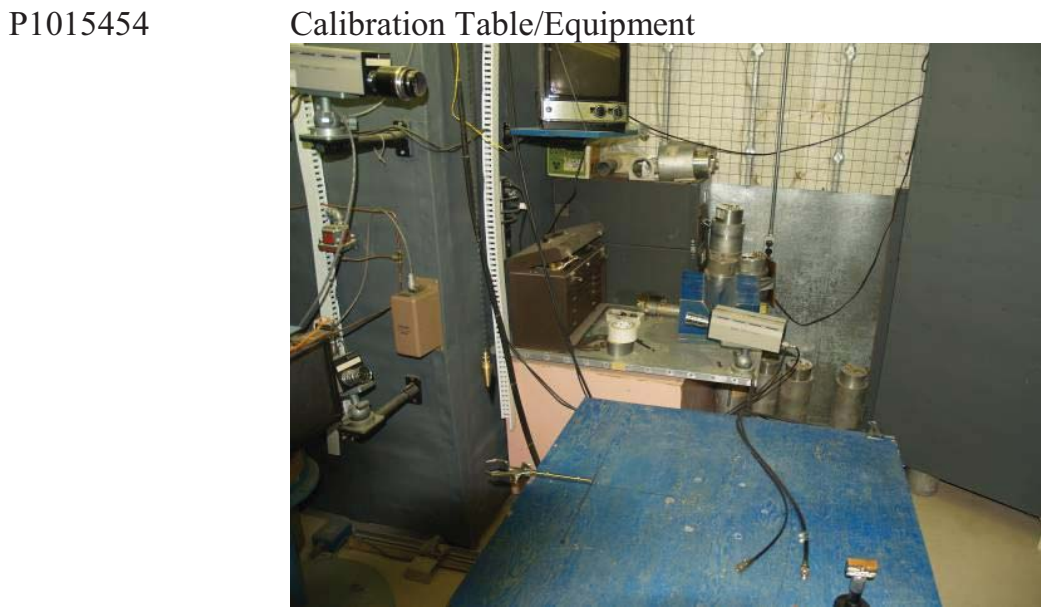

P1015455

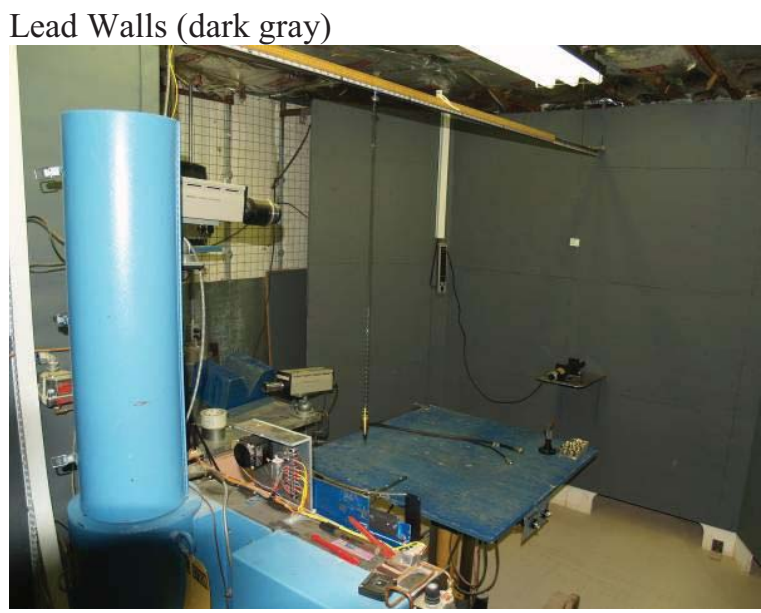


Inside Door of Calibration Room (looking east)

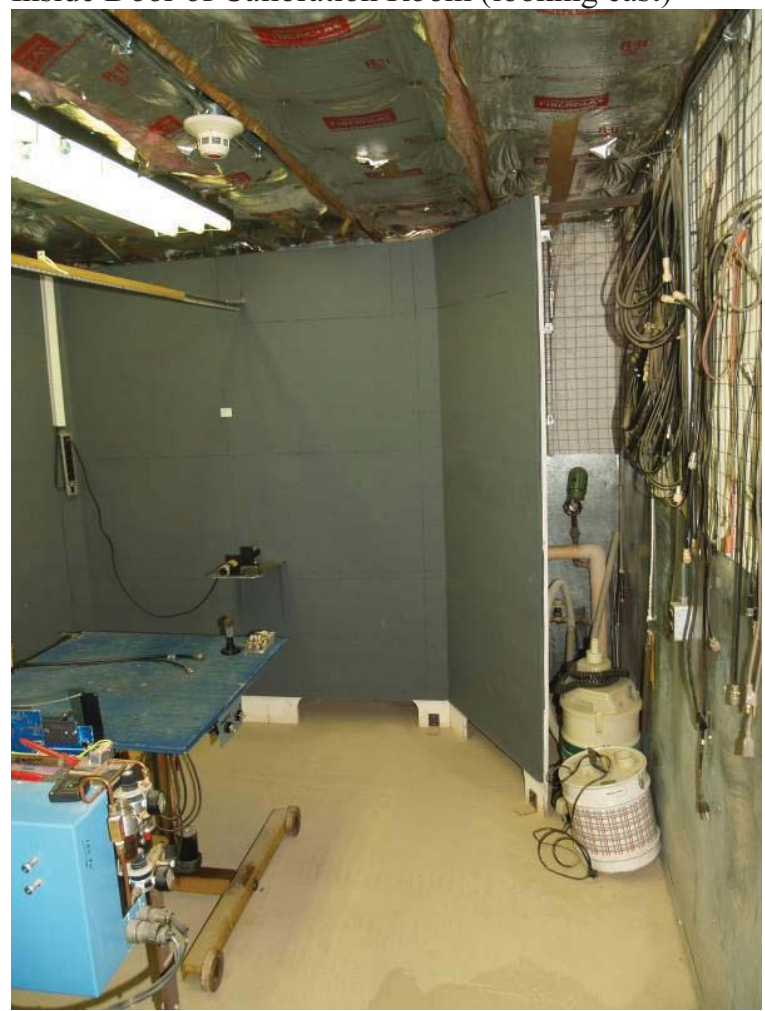

P1015457

Cabinet/Supplies in "Front Room"

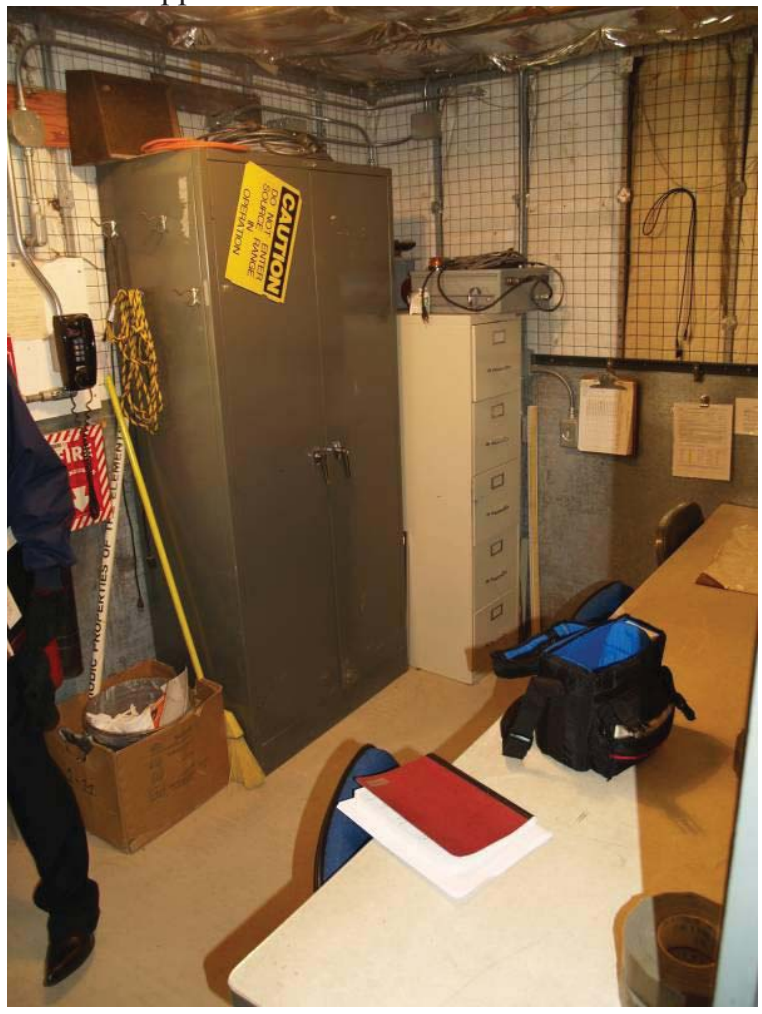




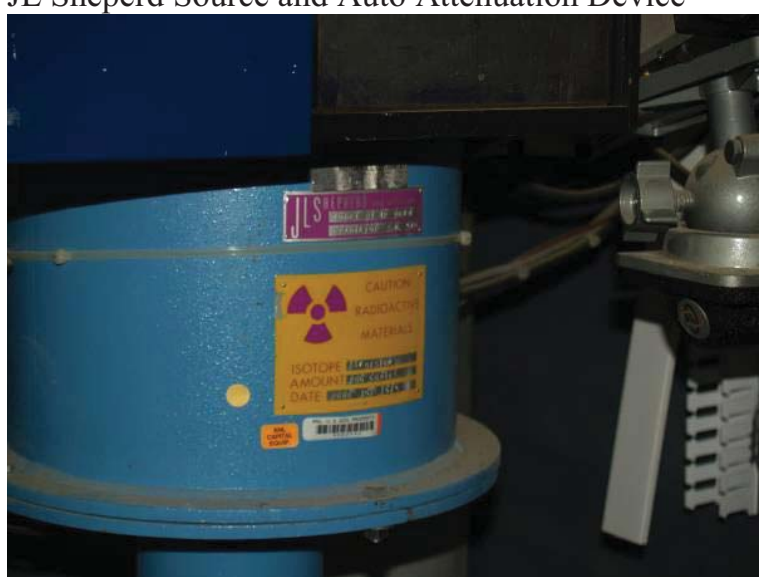


MFC-770B

P1015459

Ingersol Rand Air Compressor Placard

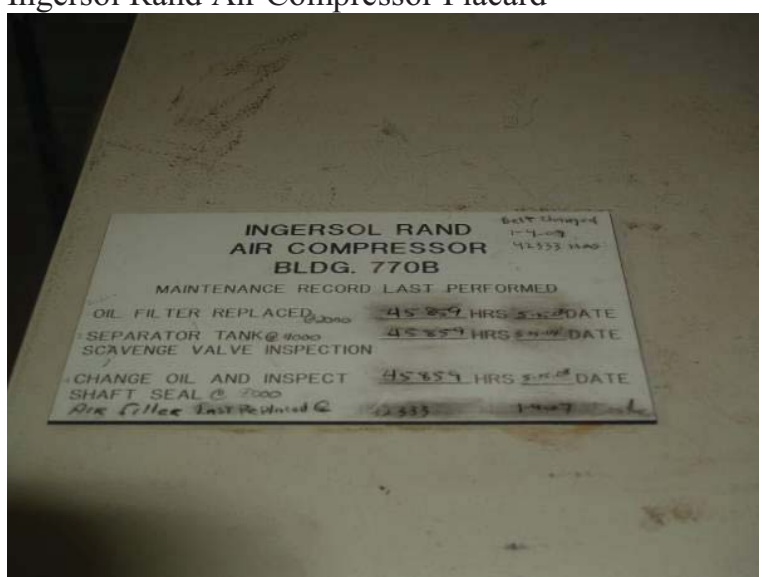

P1015460

Interior Compressed Air Piping (looking northeast)

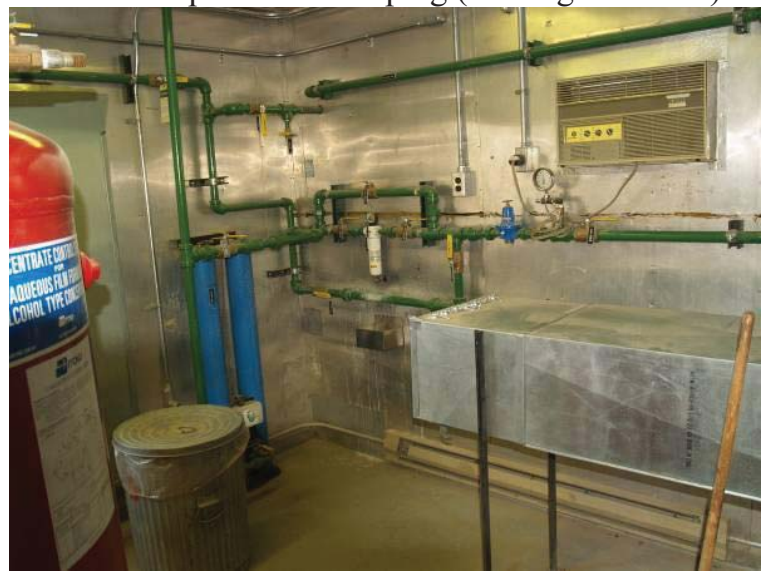

P1015461

Compressor/Pressure Tank/Ducting/Power/Controls (looking west)

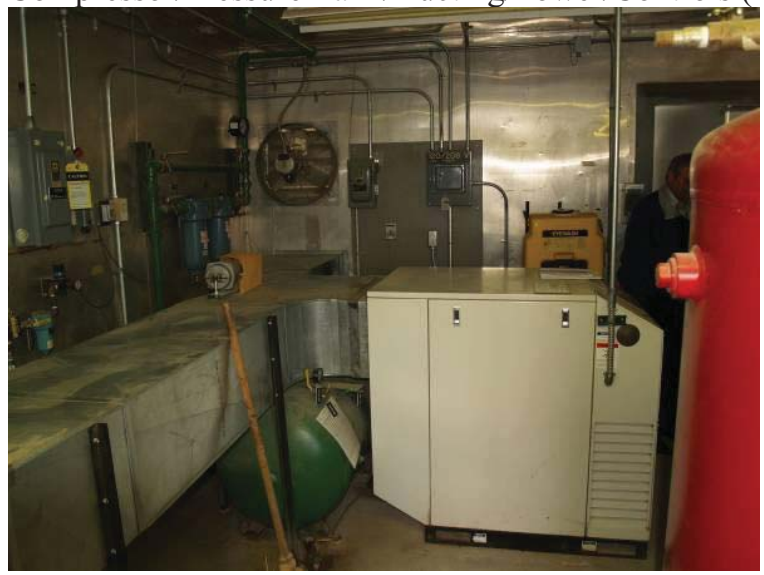


P1015462

AFFF Tank (looking south)

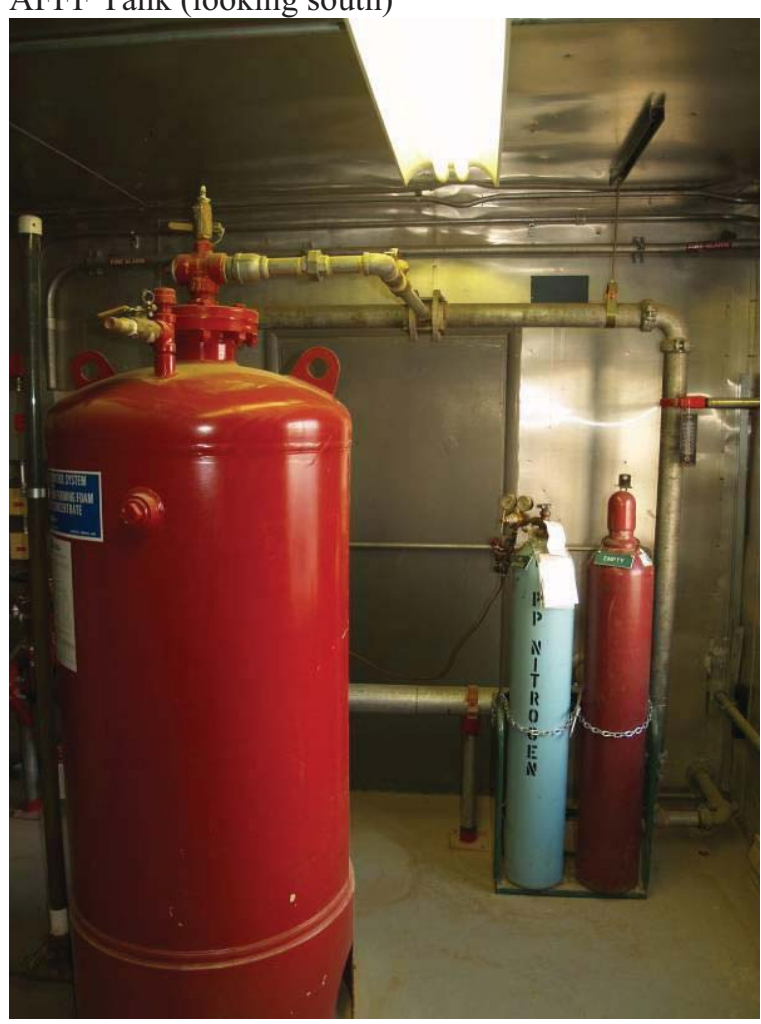

P1015463

Fire Main and Valve Controls for AFFF System (looking south)

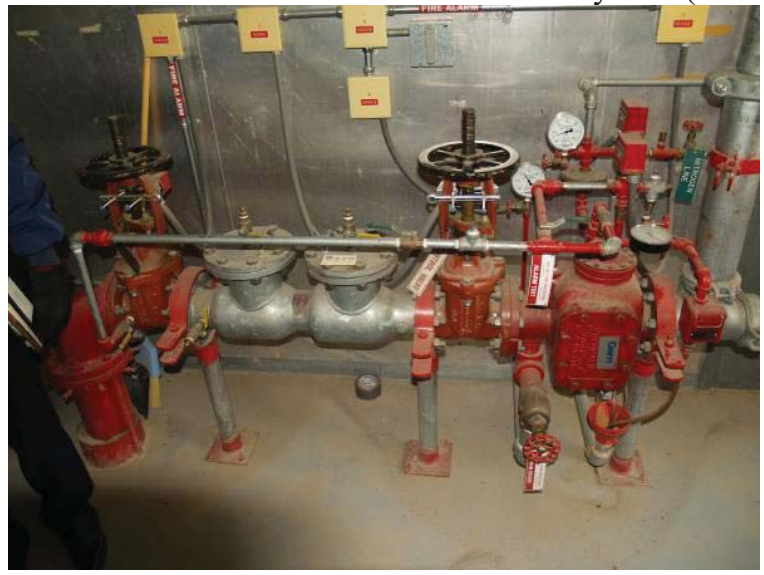


P1015464

P1015465
AFFF Tank

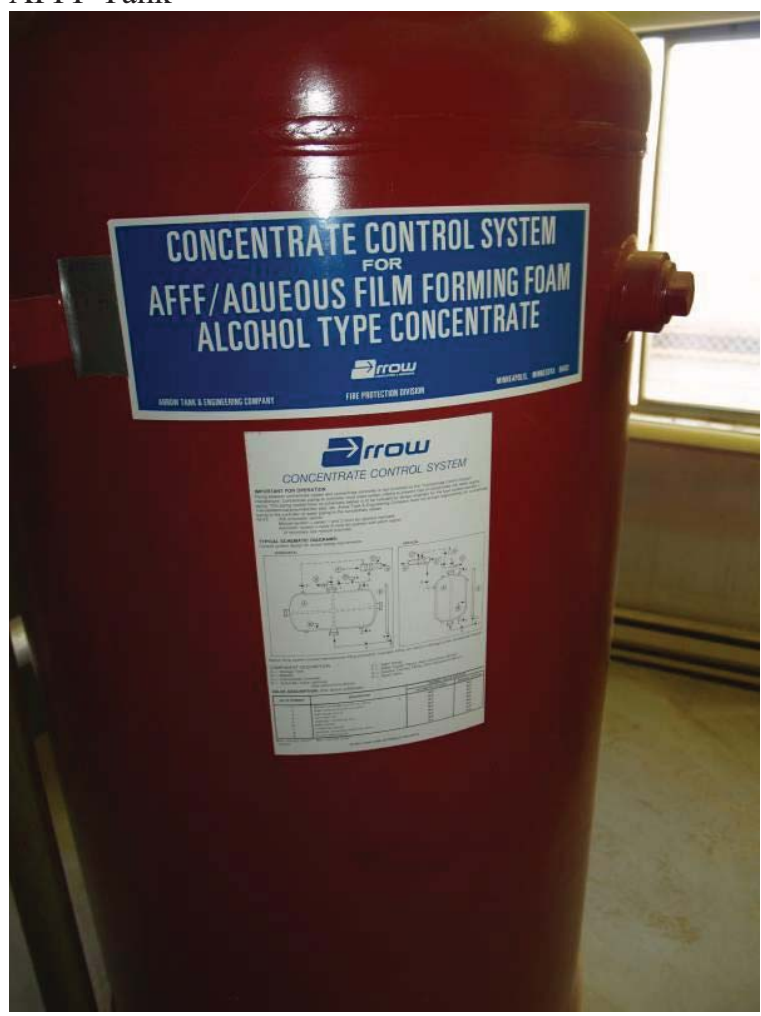

AFFF Piping (looking east)

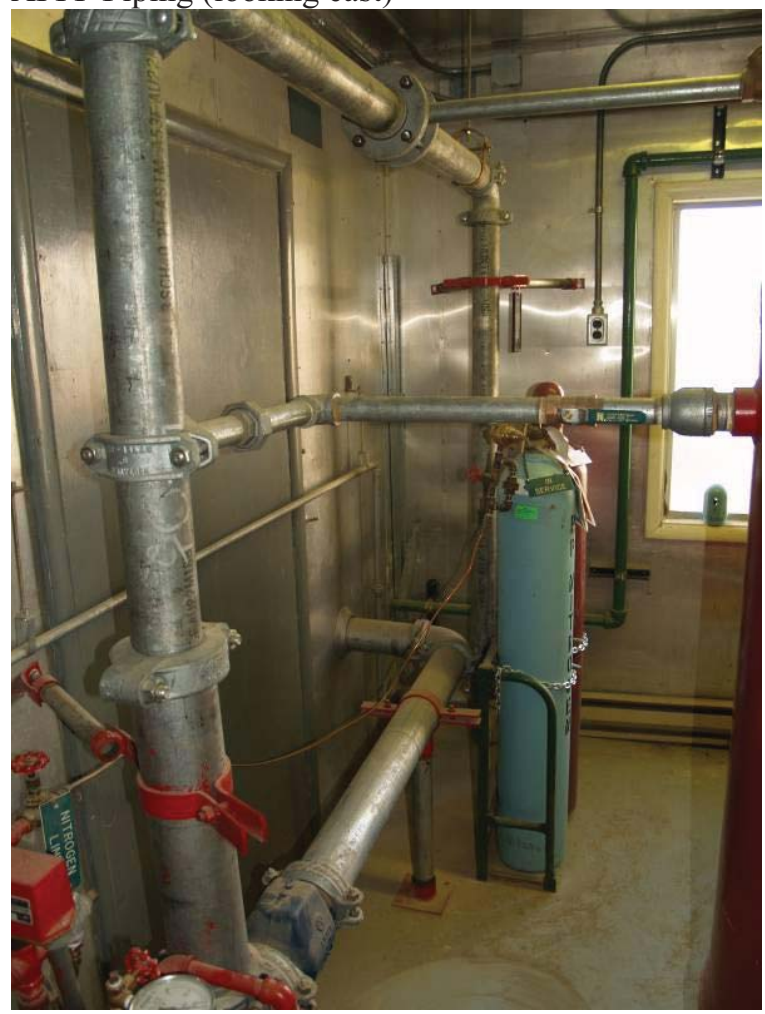




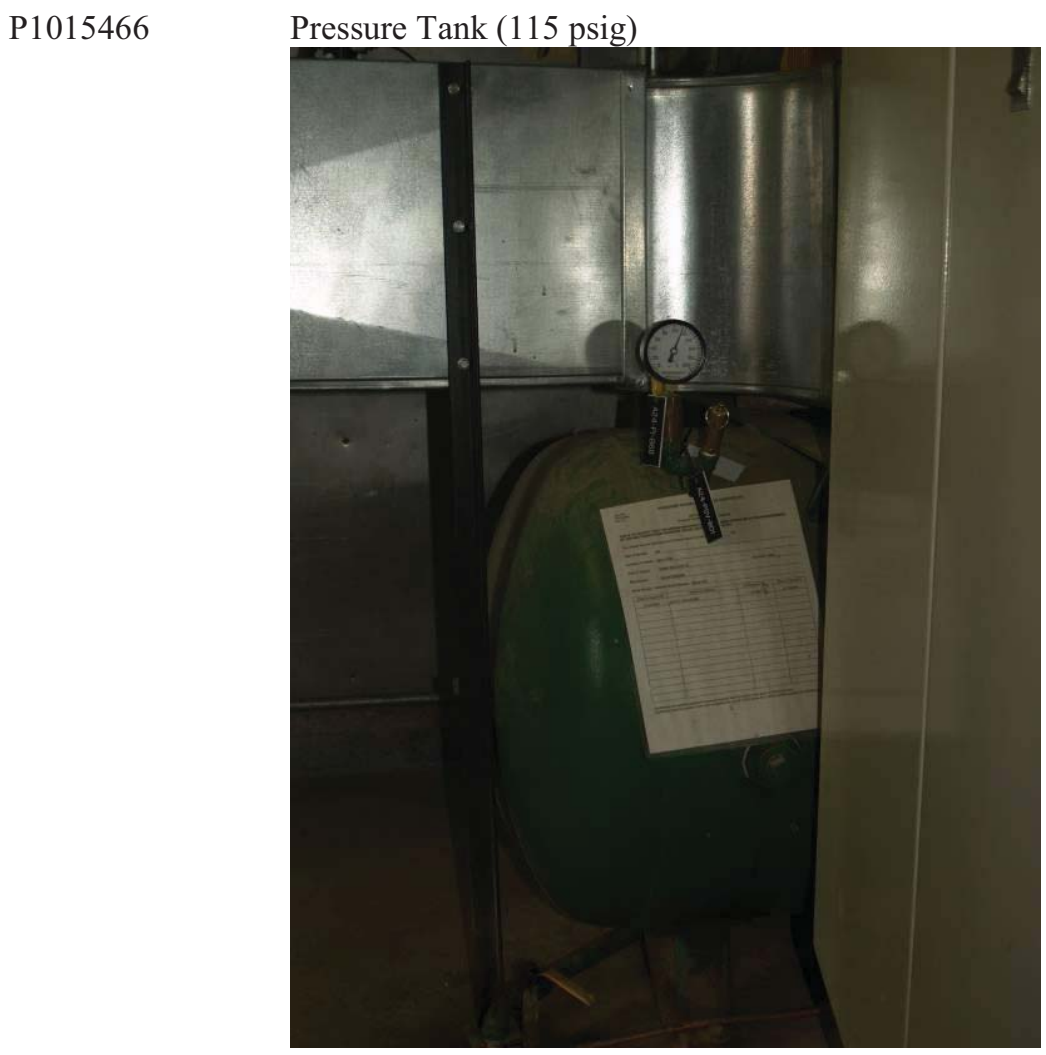




\section{Site Photos}

P1015467

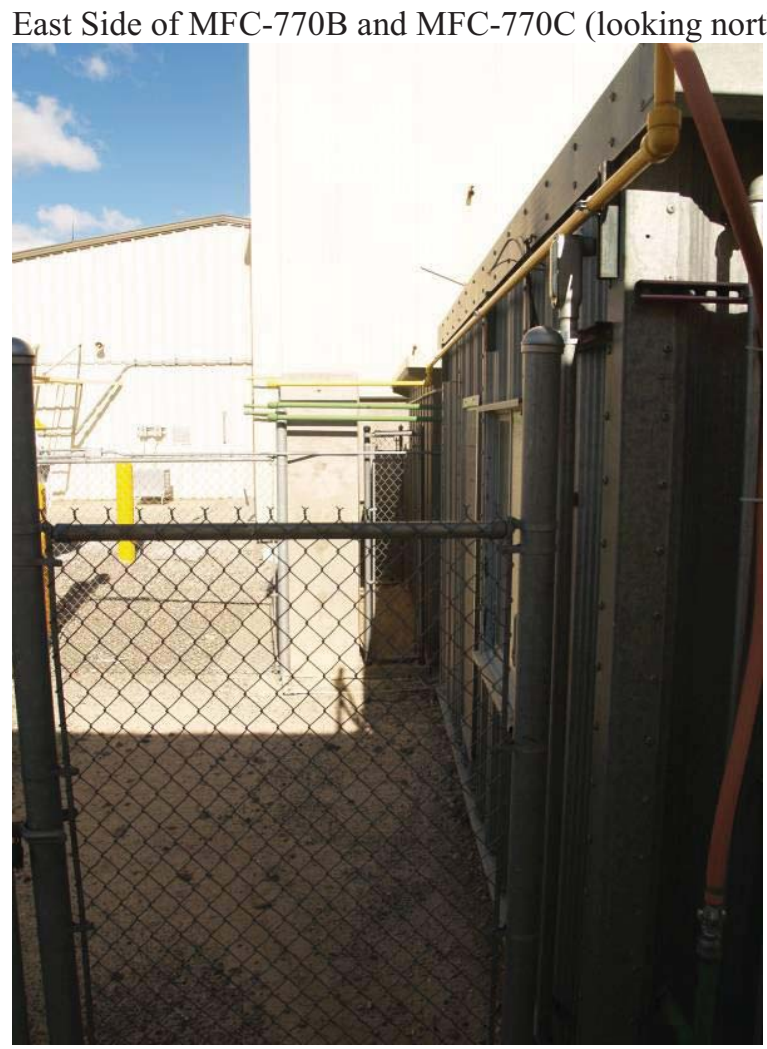

P1015468

Expanded View of East Side of MFC-770B and MFC-770C (looking north)

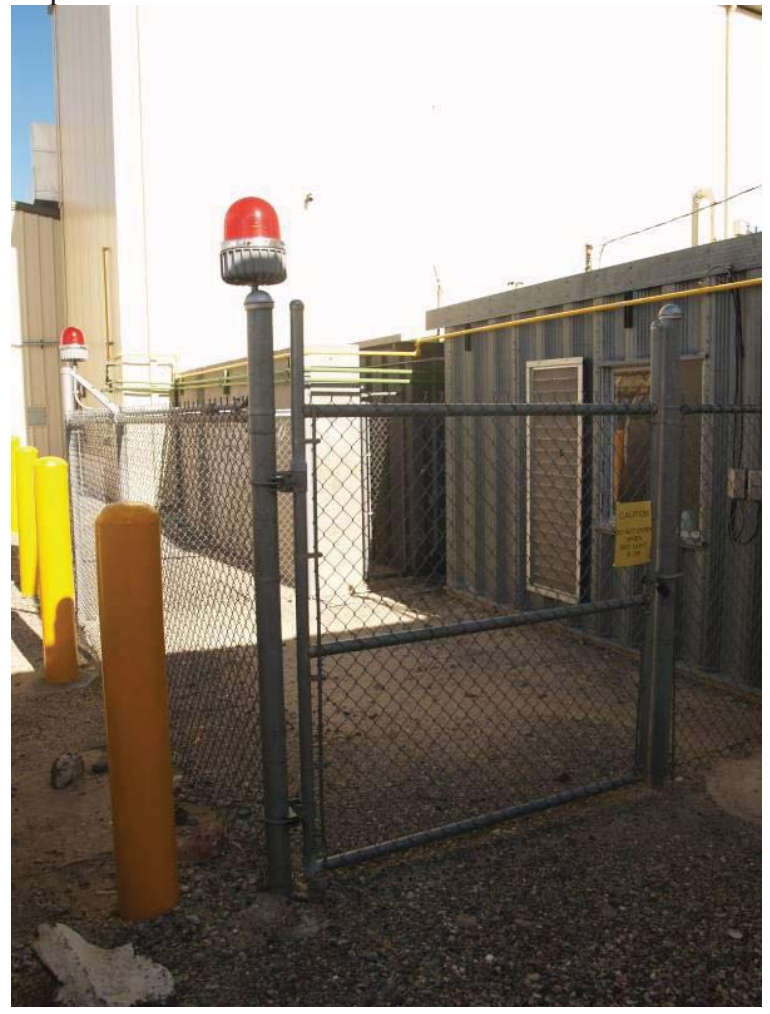




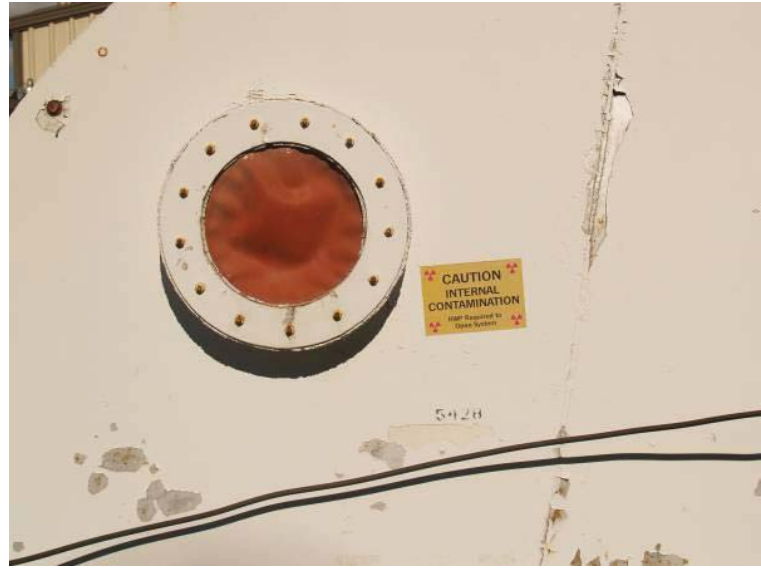

P1015470

Expanded View of Internal Contamination Placard on Vessel Stored on East Side of MFC-770B and MFC-770C/Portable Storage Shed (looking northwest)

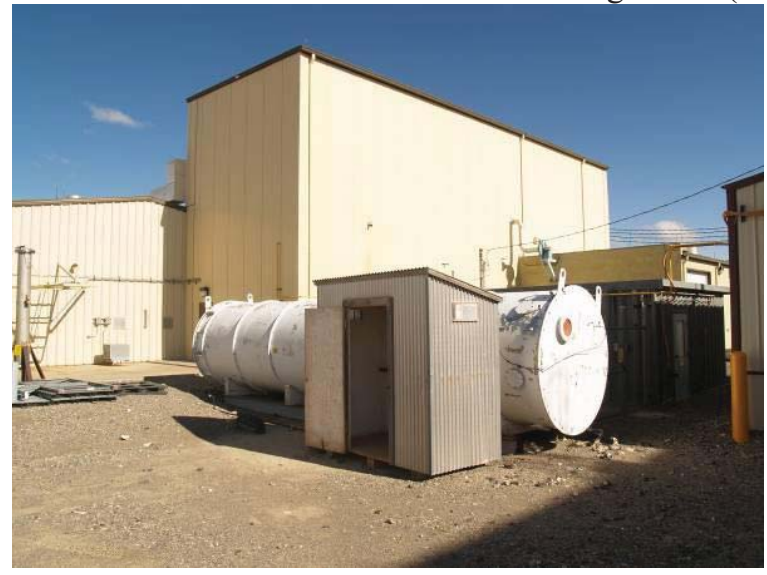

P1015471 Cargo Container/Abandoned Caustic Storage Tank (looking north)

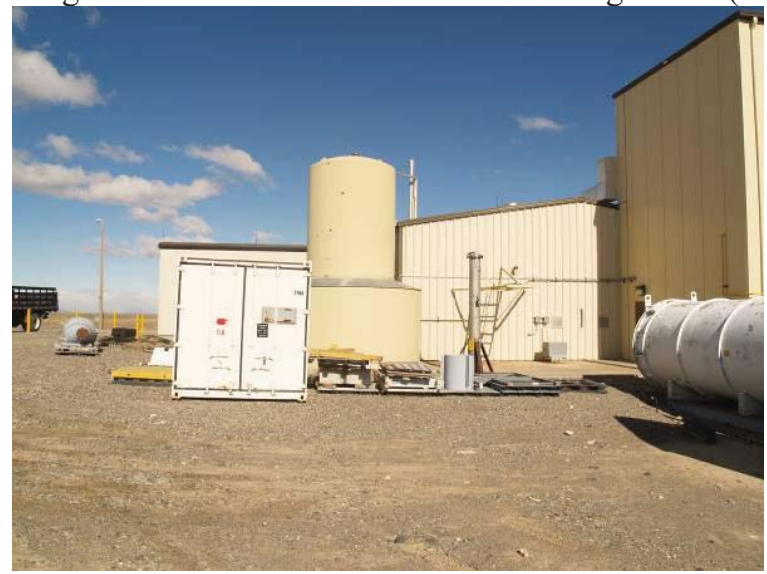


P1015472

MFC-799A (Caustic Storage Tank Building) and Abandoned Caustic Storage Tank (looking northwest)

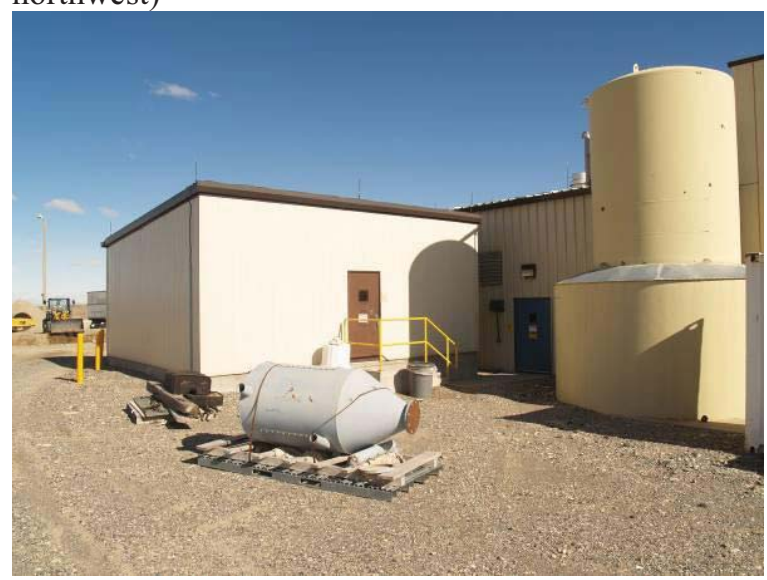

P1015473

Abandoned Caustic Storage Tank (looking west)

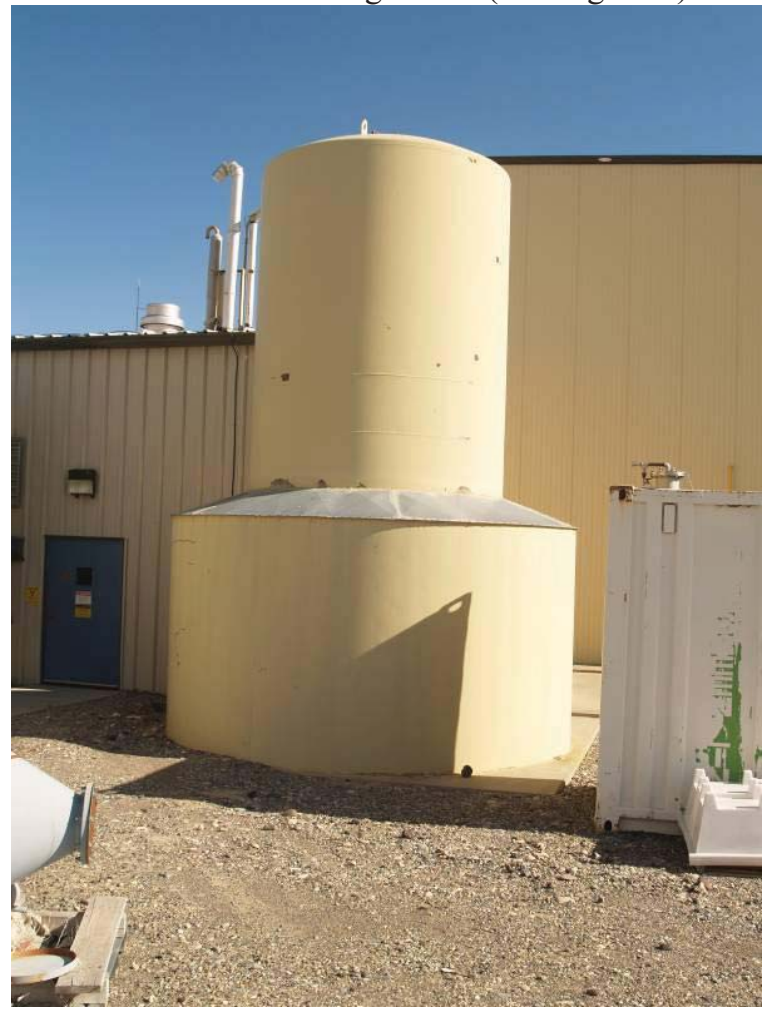


P1015474

Barrel Washing Pad with Vessel with Internal Rad Contamination (looking west)

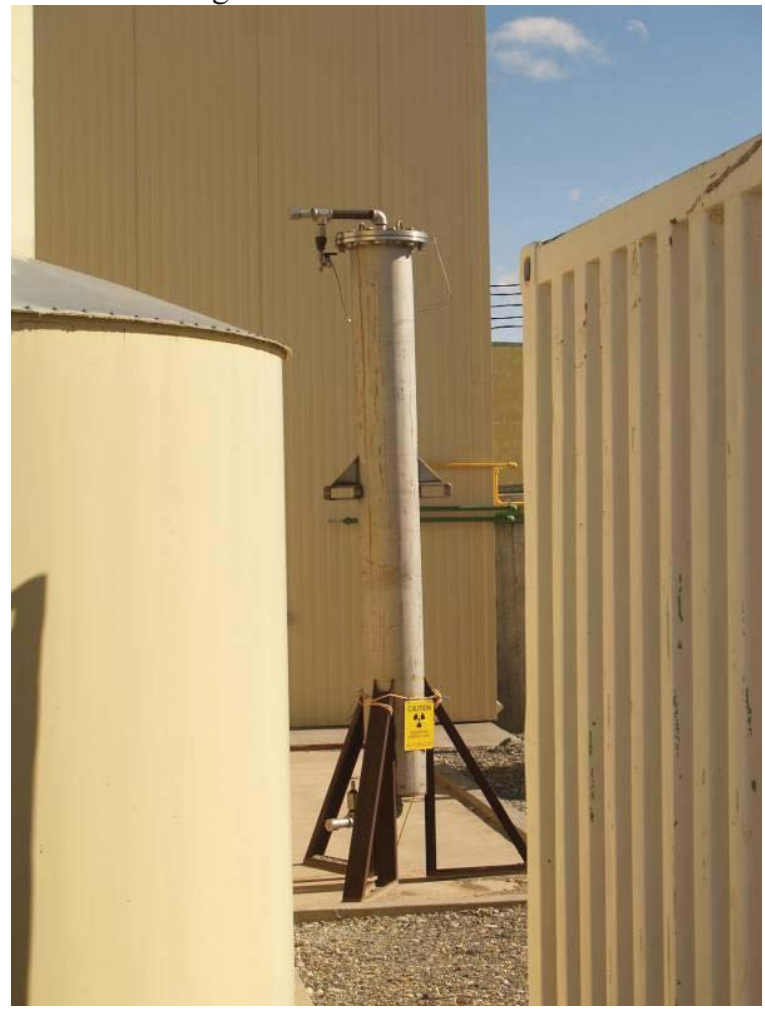

P1015475
Building 793 (looking south)

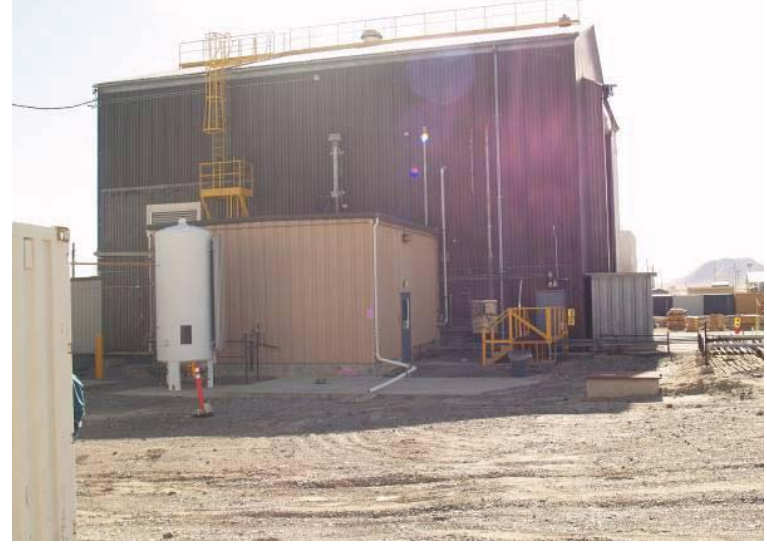


P1015476

P1015477

P1015478
Alcohol Storage Pad, MFC-793A

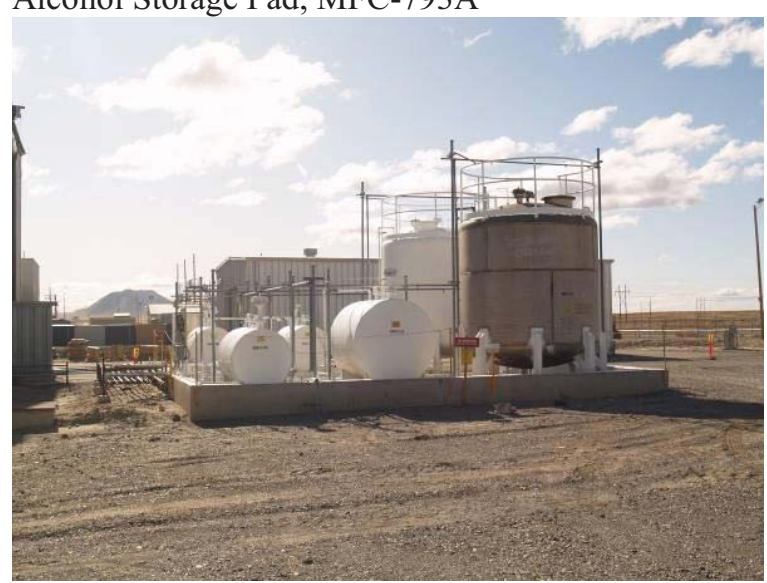

Barrel Washing Pad with Vessel with Internal Rad Contamination (looking west)

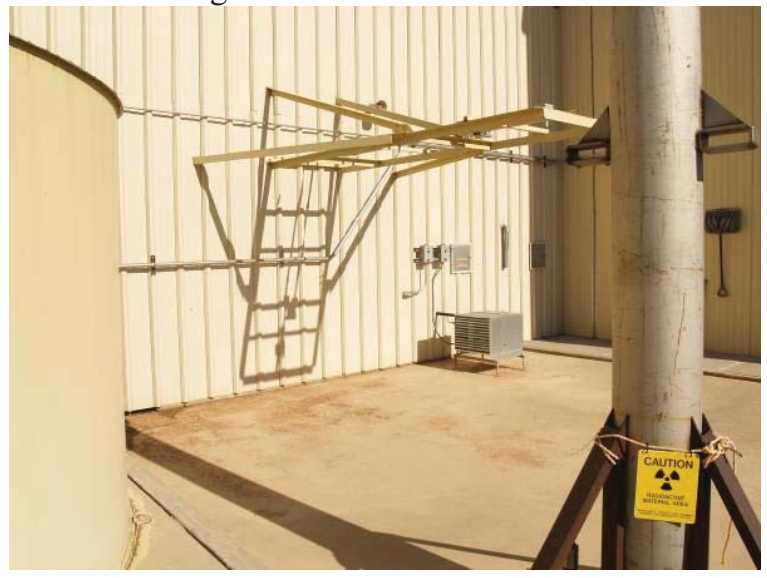

From Barrel Washing Pad (looking south) (NOTE: Includes Bioshield Wall Around MFC-770C

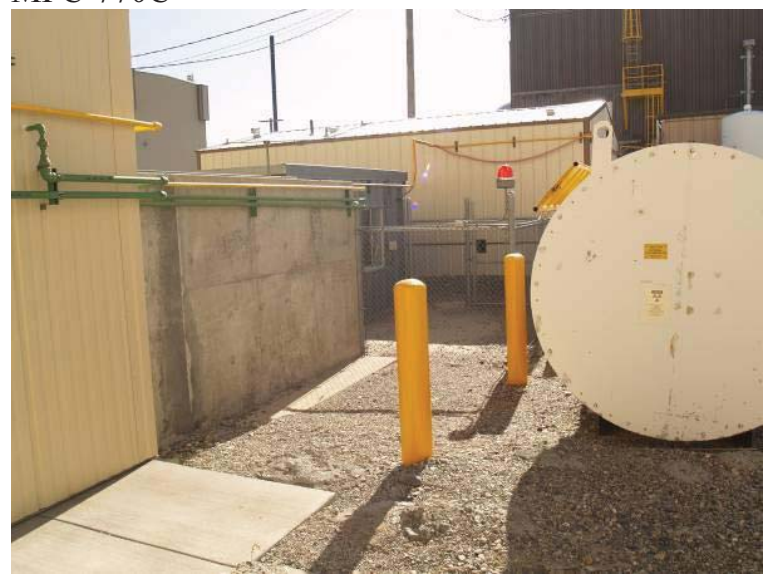


Expanded View of Internal Contamination Placard on Vessel Stored on East Side of MFC-770B and MFC-770C/Portable Storage Shed (looking south from Barrel Washing Pad)

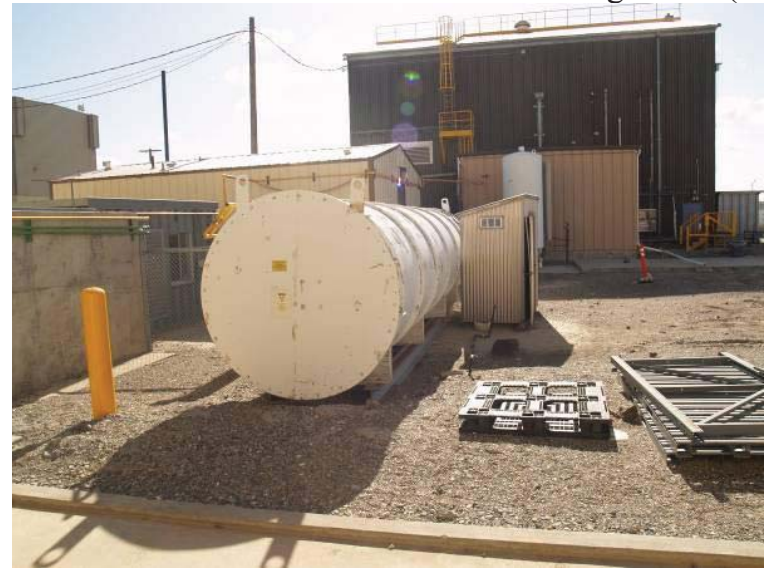

P1015480

Barrel Washing Pad Drain - located in northeast corner

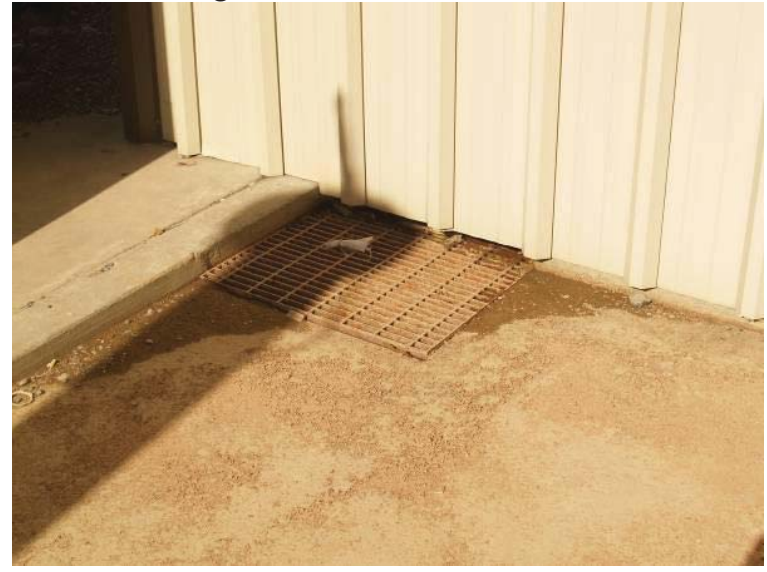

P1015481 Confined Space Placard on Abandoned Caustic Storage Tank

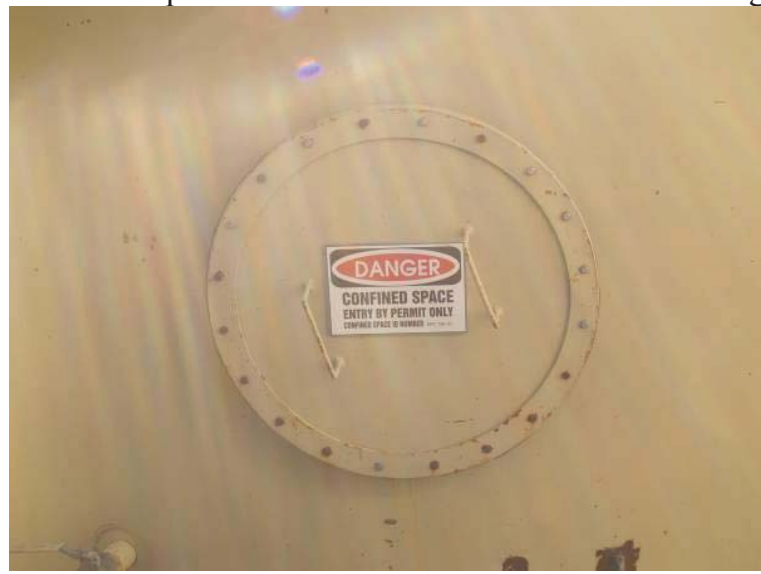


P1015488

P1015489

P1015490
MFC-799 (looking southwest)

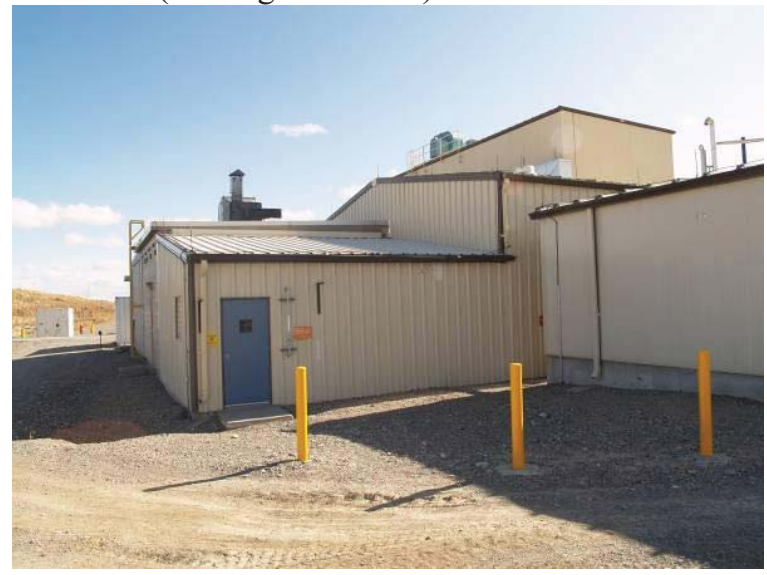

MFC-799A (looking southwest)

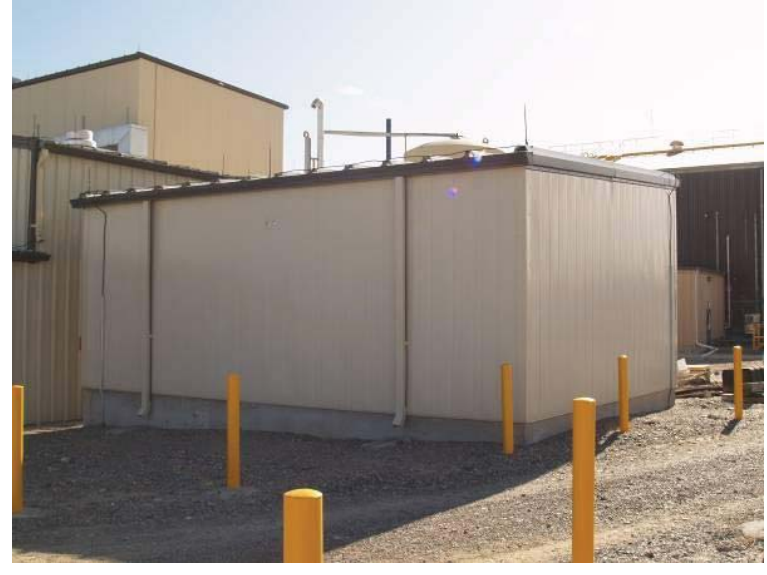

Two 4-in Diameter Drain Pipes from MFC-799 and Barrel Washing Pad (Drains to North Area Drainage Ditch)

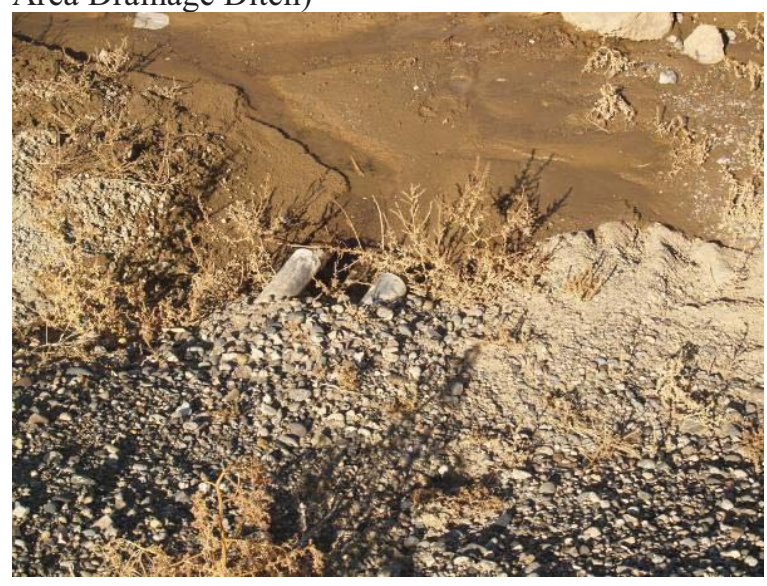


P1015491

12-in Diameter Culvert (Stormwater, located west of 4-in drain pipes)

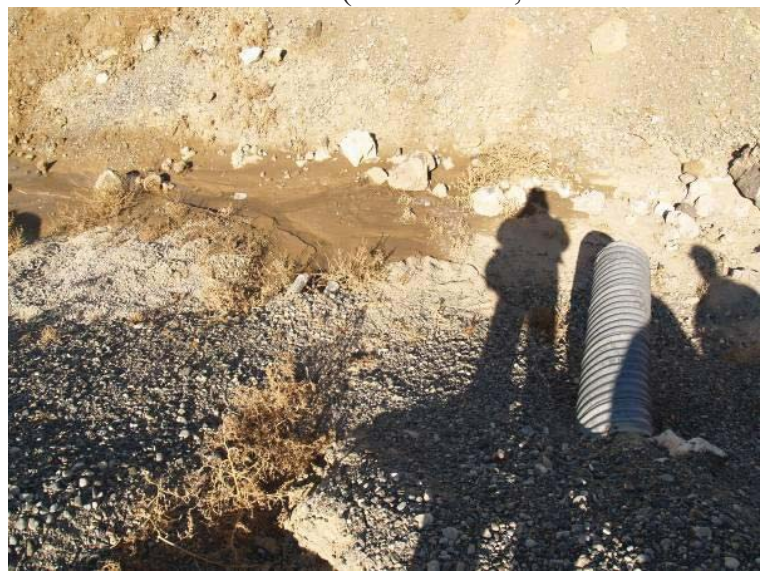

P1015492

Drainage Ditch/Concrete Weir Structure approximately 20 yards downstream (looking east)

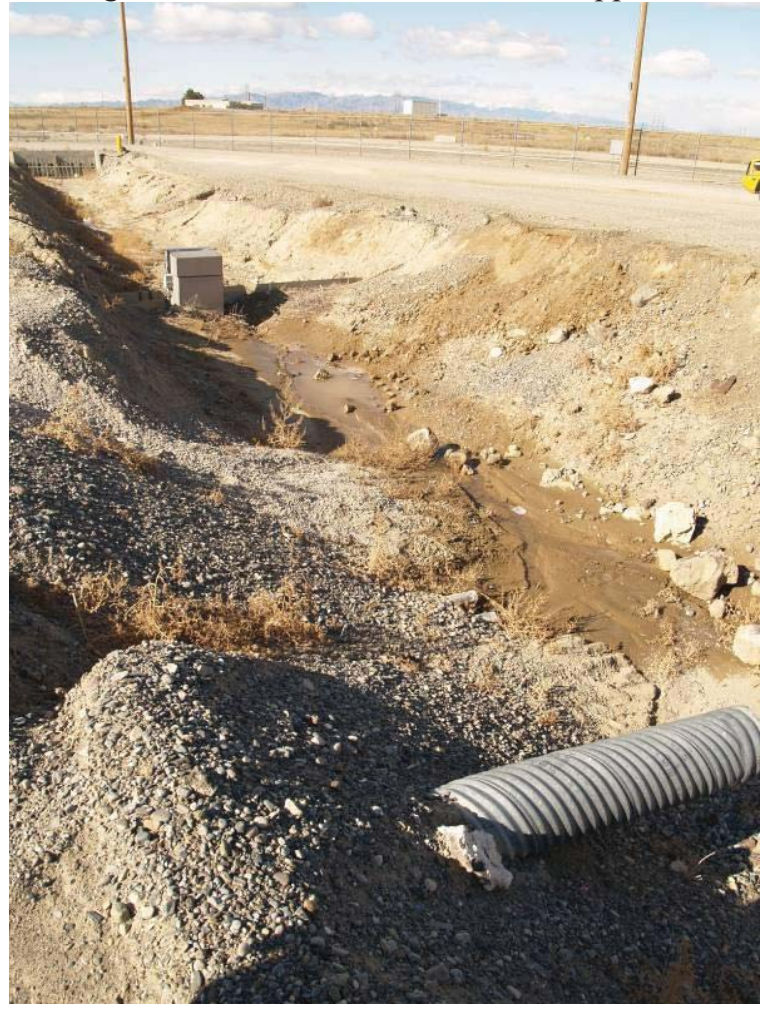


P1015493

Northeast Exterior Corner of Barrel Holding Room

P1015494

P1015495

North Side of MFC-799
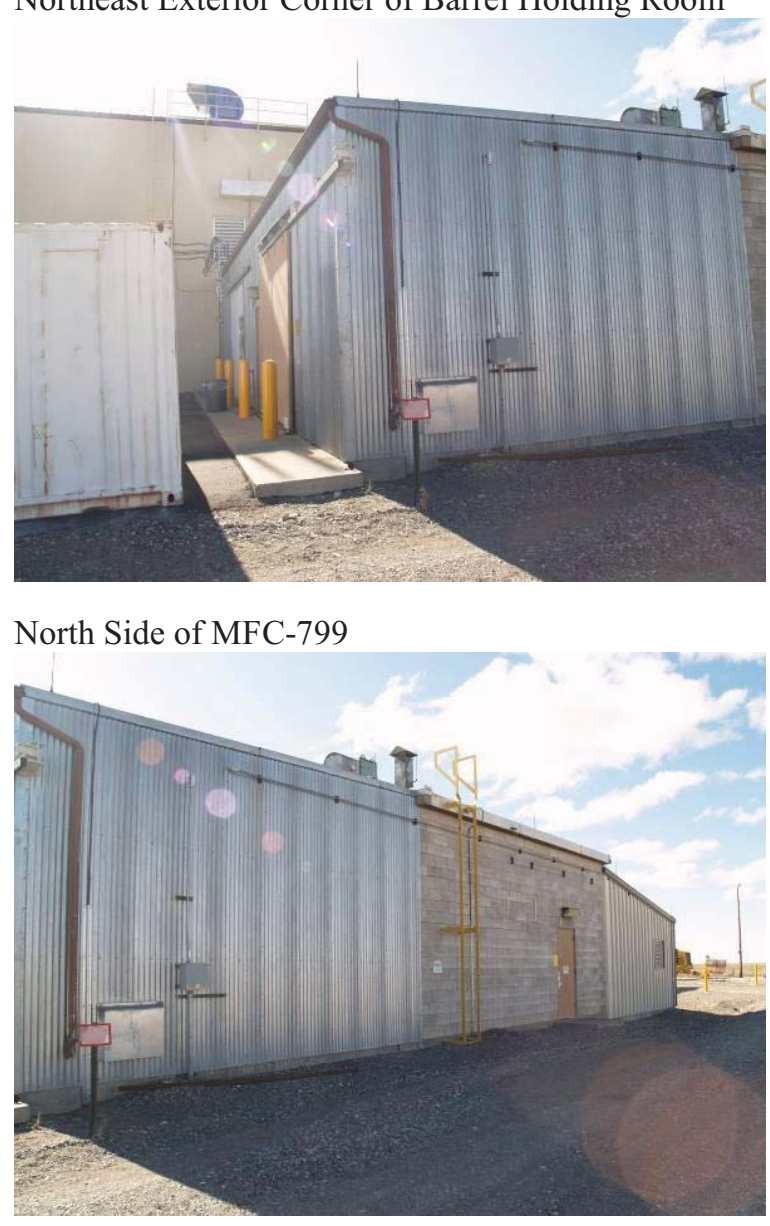

20-ft Cargo Storage Container RSU-1765

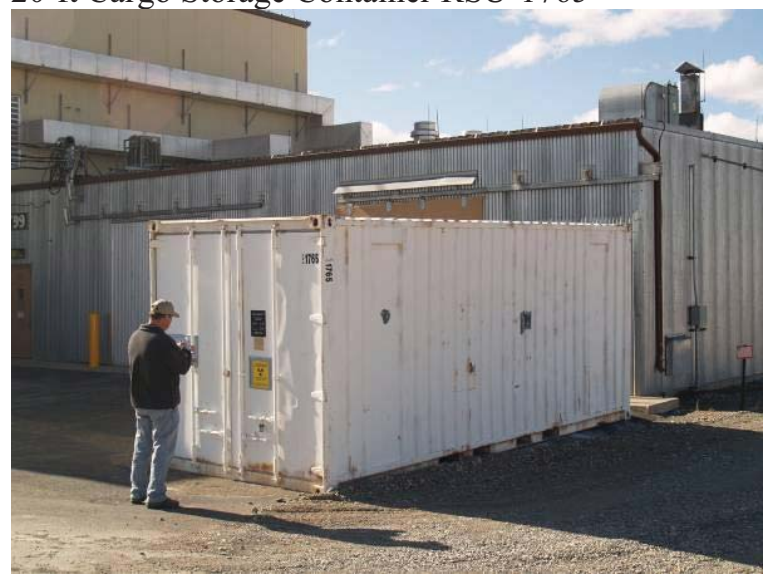


P1015496

P1015497

P1015498
Expanded View of 20-ft Cargo Storage Container RSU-1765 (looking southeast)

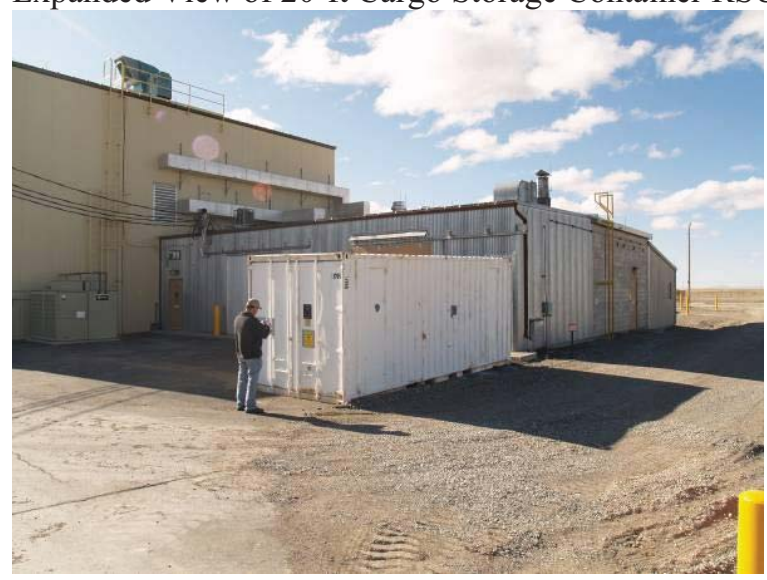

MFC-799 with Carbonate Sodium Process Facility Addition (looking southeast)

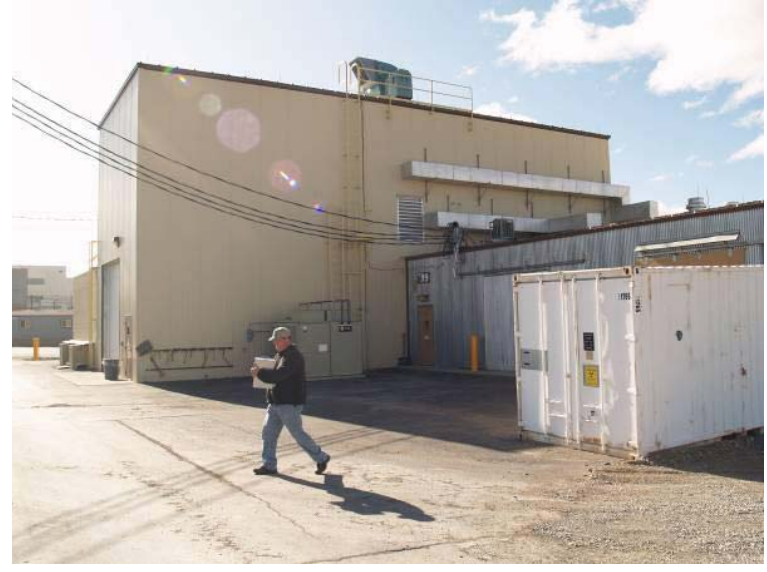

20-ft Cargo Storage Container RSU-1733 (looking west - located across street from RSU 1765)

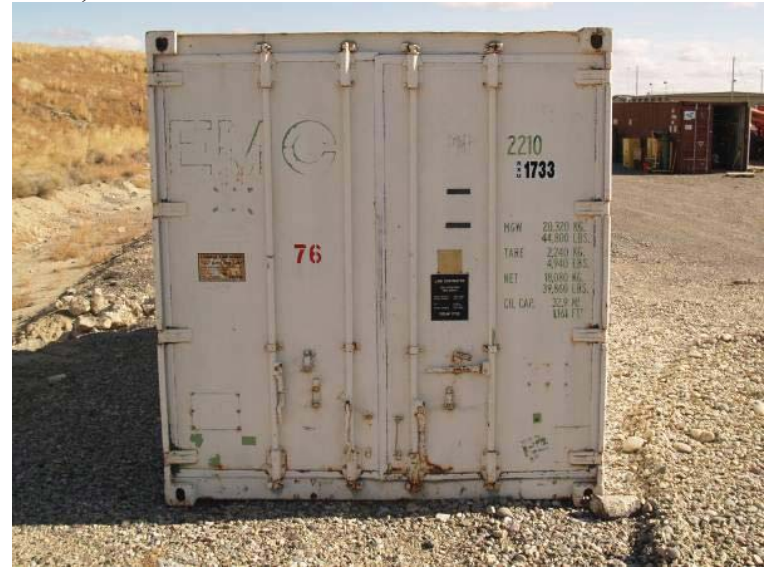


P1015499

20-ft Cargo Storage Container RSU-1765 (looking east)

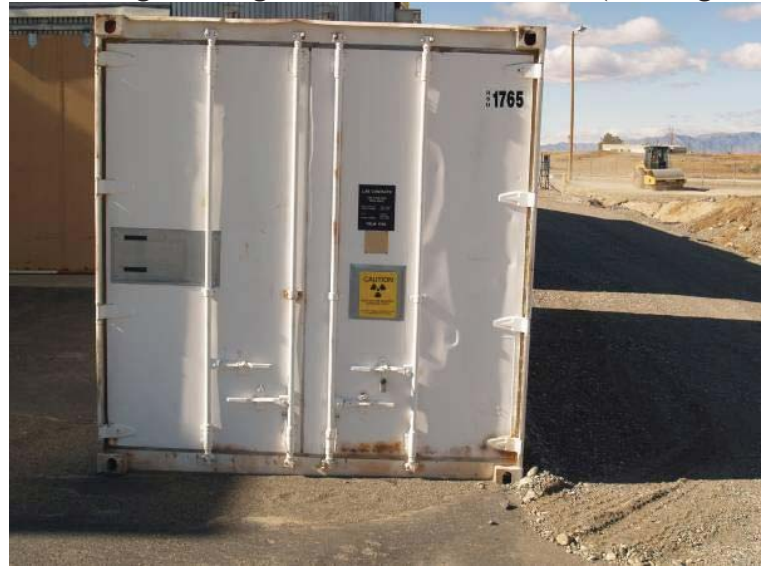

P1015500

Power Pole for Main Power Feed to MFC-799 (looking southwest)

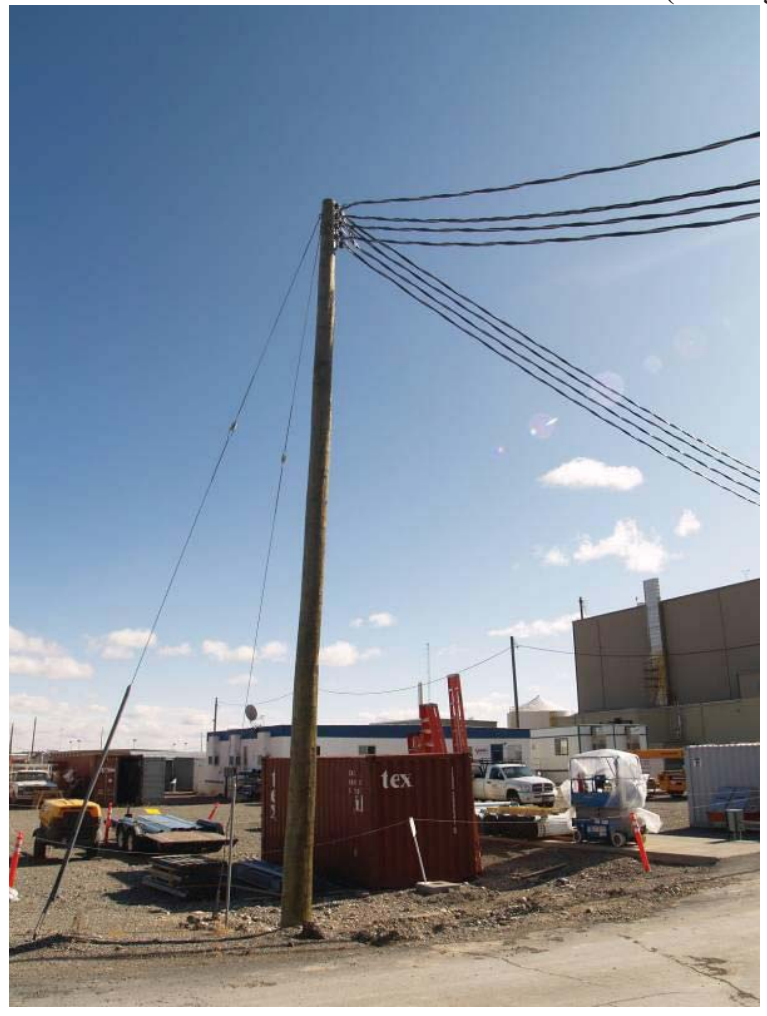


P1015501

Power Transmission Lines and Pole $/ \mathrm{CO}_{2}$ Storage Tank Pad

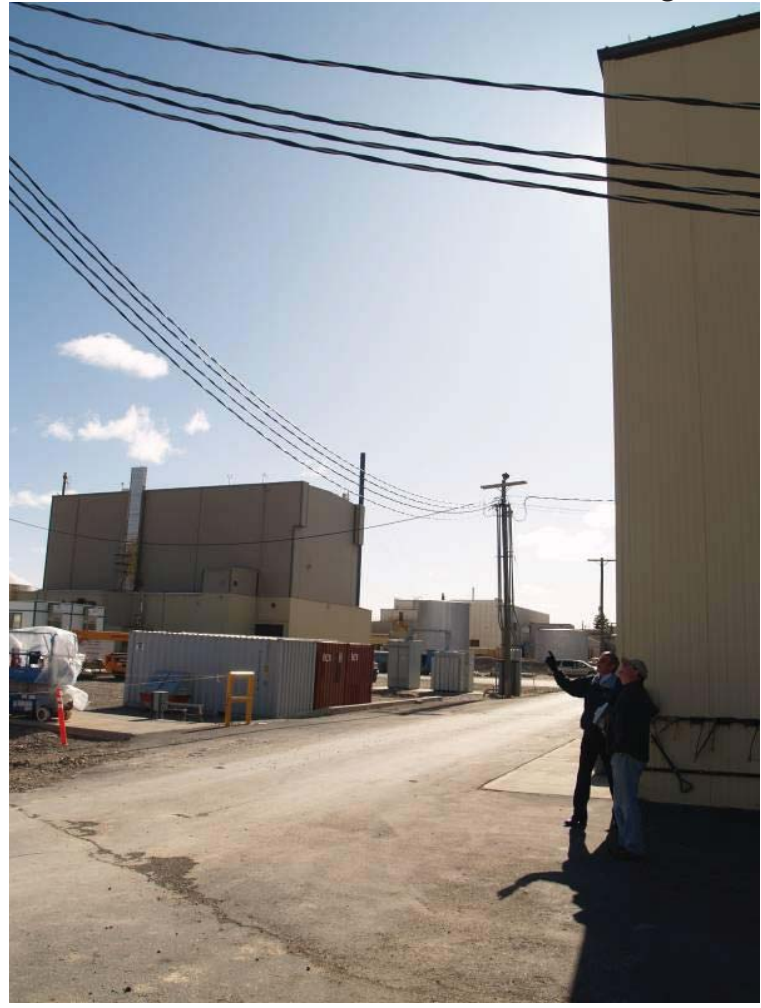

P1015502
Main Power Weatherhead Feed into MFC-799

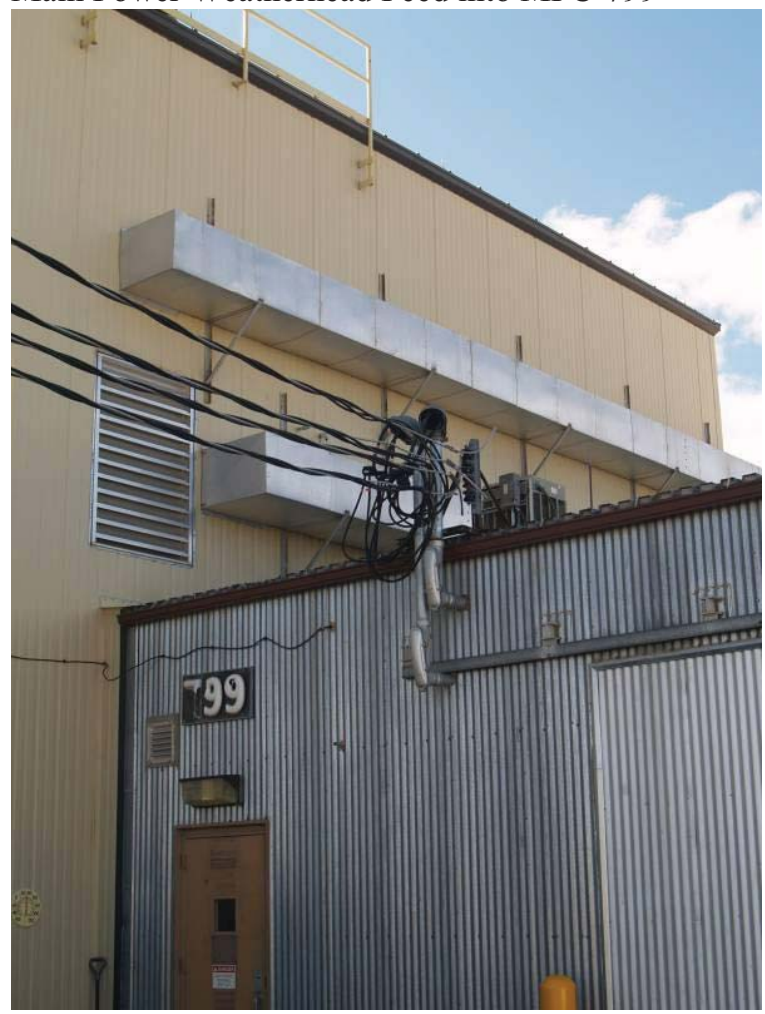


P1015503

P1015504

P1015505
TRANE Unit for Carbonate Sodium Process Facility

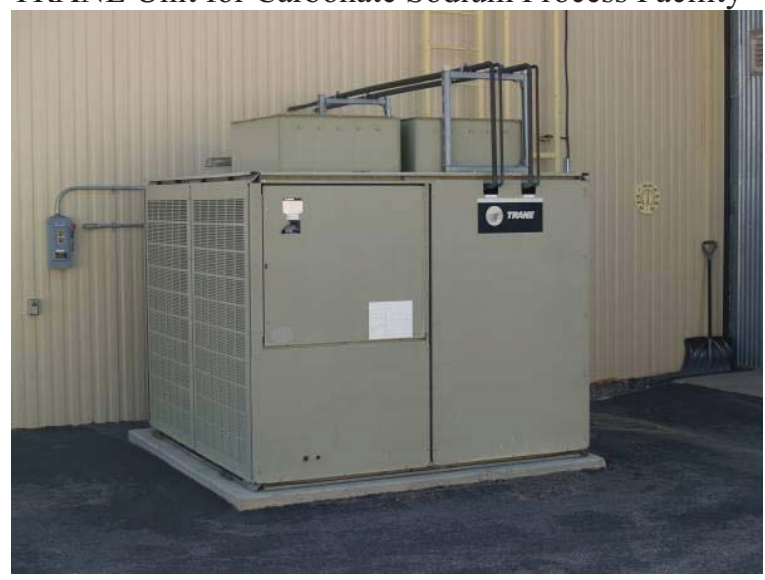

External View of MFC-770B (looking northeast)

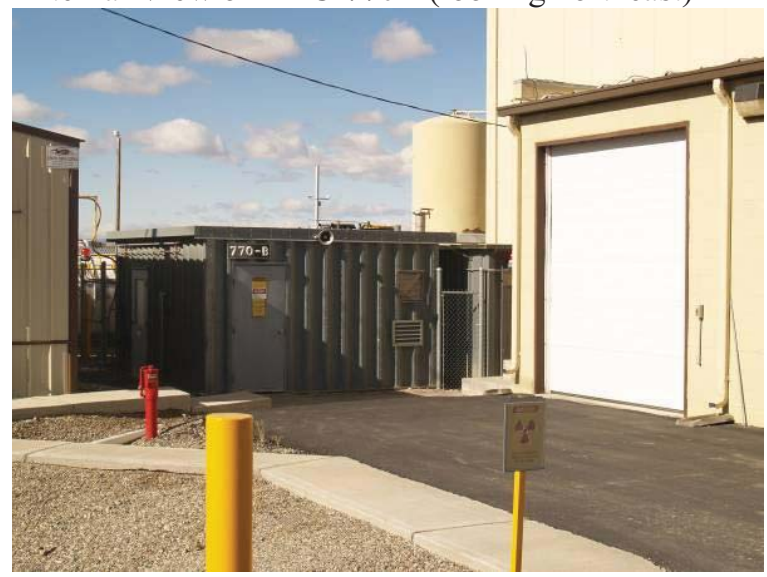

Expanded View of MFC-799 (Sodium Processing Facility) (looking east by northeast)

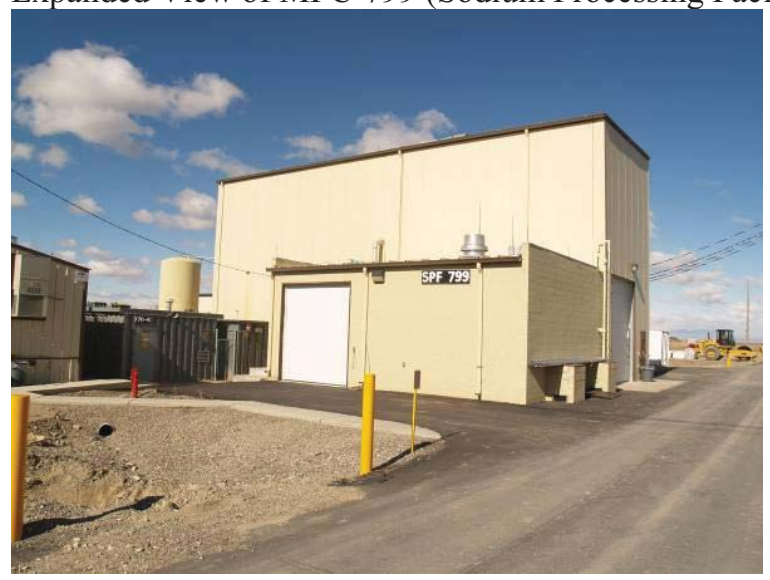


P1015506

Expanded View of MFC-799 (Sodium Processing Facility) (looking northeast)

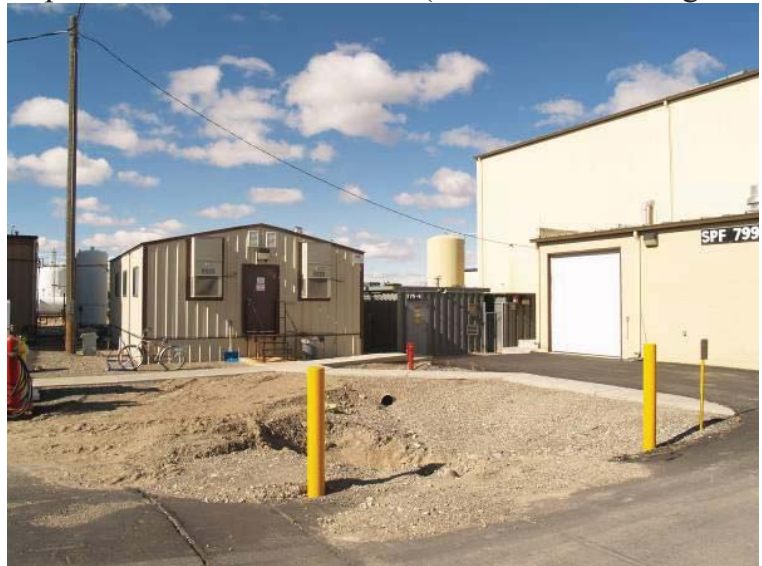

P1015507

P1015508
MFC-793 (looking east)

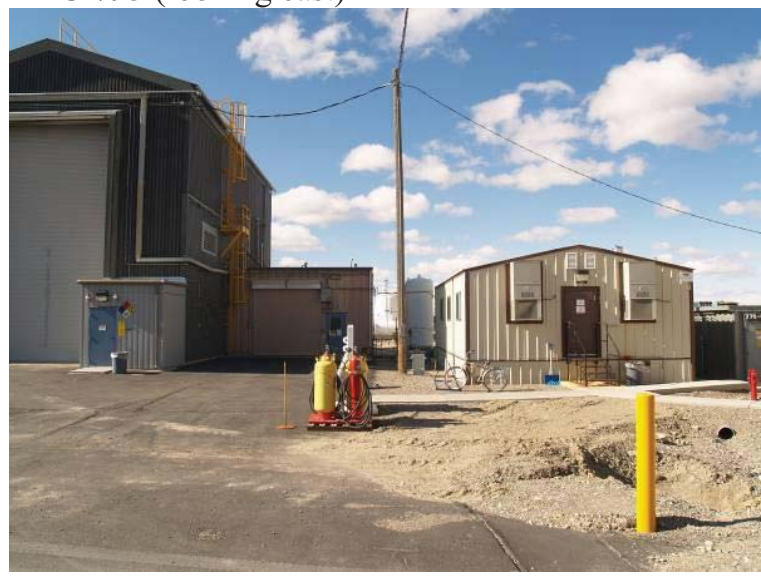

MFC-793 (looking east)

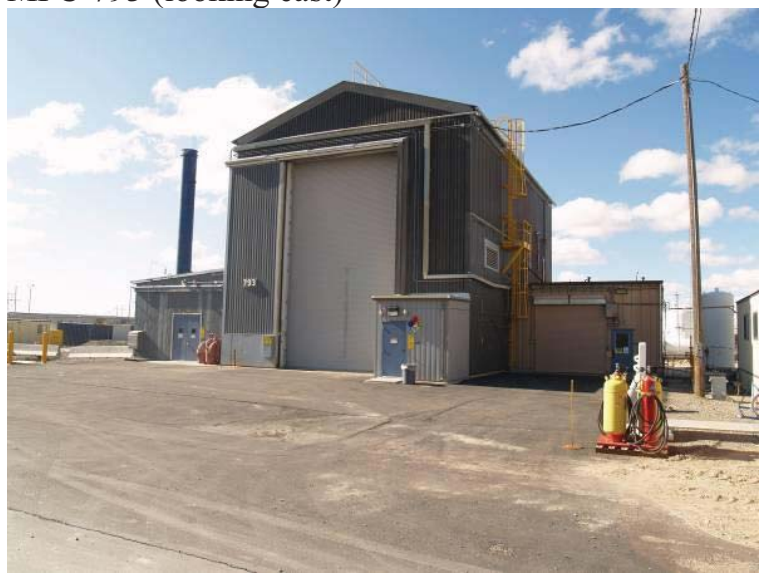


P1015509

Main Power Distribution Pole PP110, Input is PP111 Ckt \#1 480 Volt

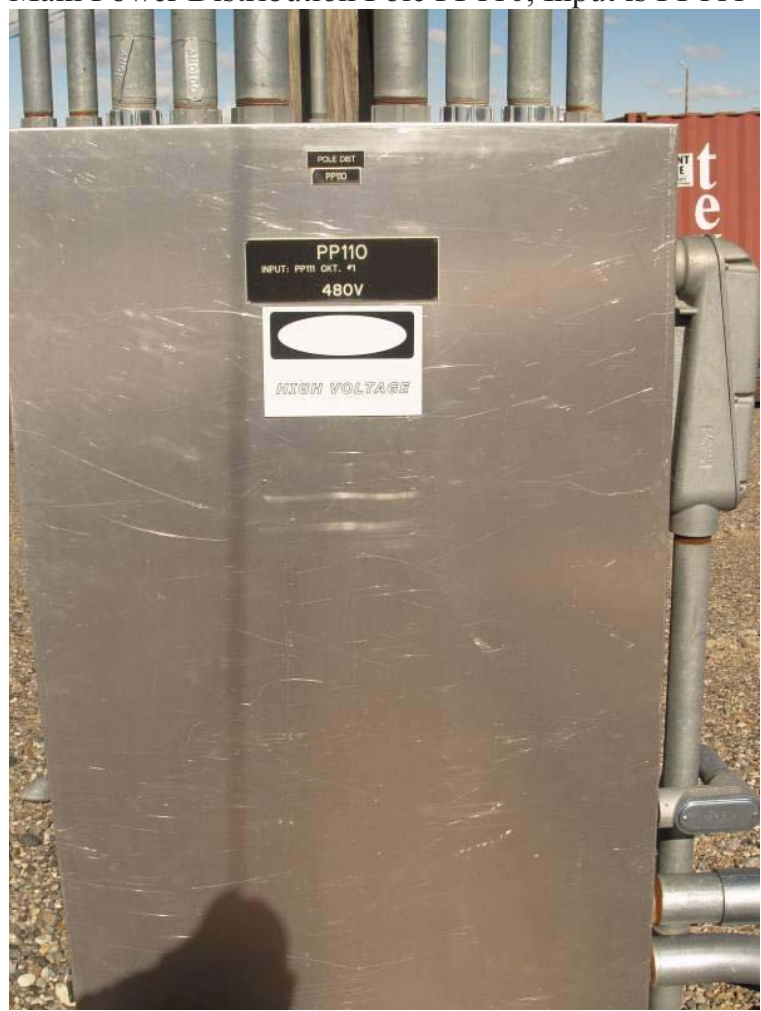

$\mathrm{P} 1015510$
Power Pole Weatherhead (PP110)

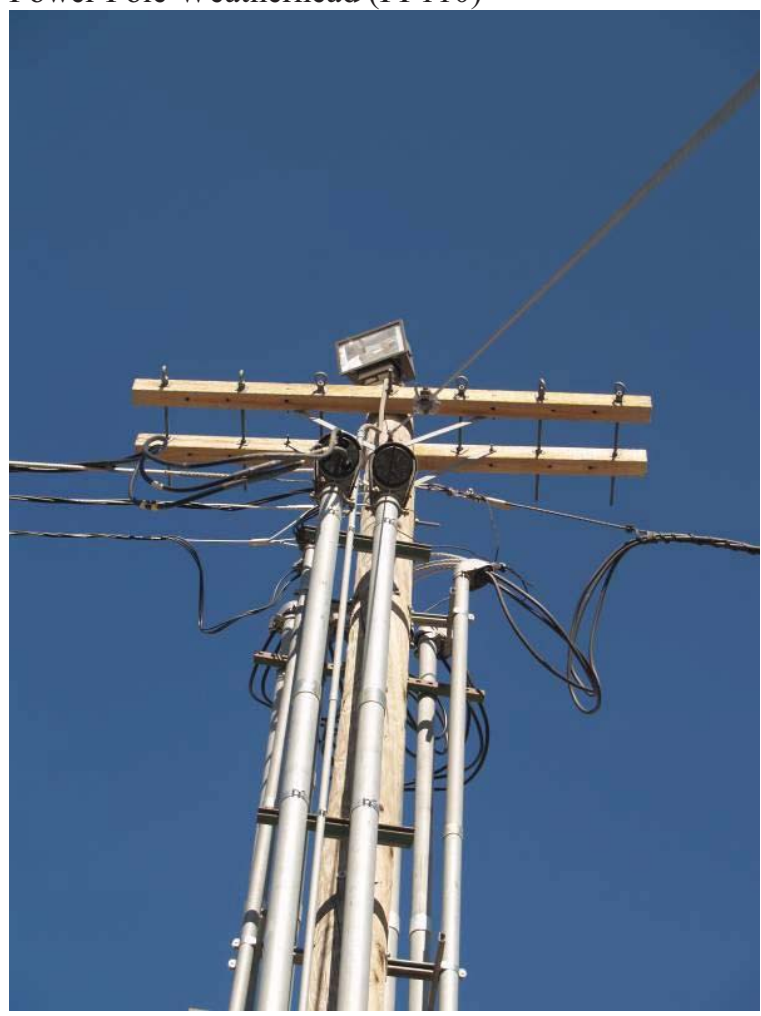


P1015511

Northeast View of MFC-770B and MFC-770C (NOTE: Emergency Diesel Generator Pad [generator removed])

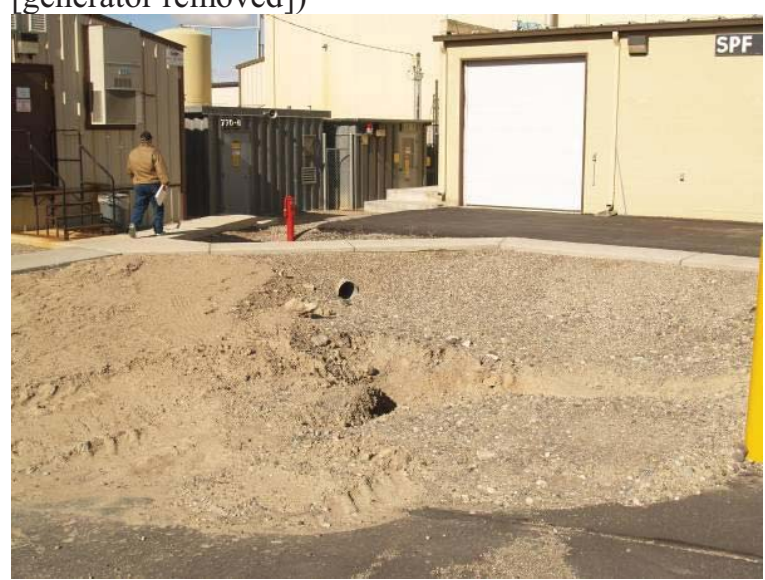

P1015512

Detail of Northeast View of MFC-770B and MFC-770C (NOTE: Emergency Diesel Generator Pad [generator removed])

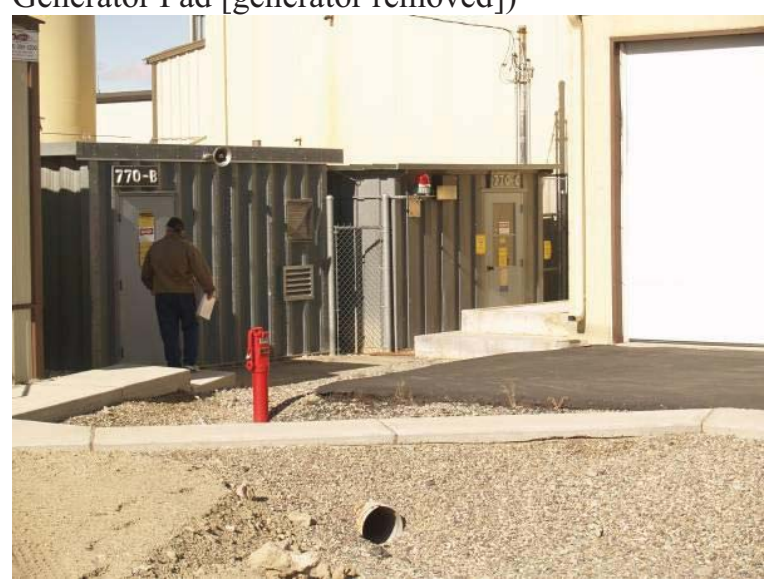


MFC-799A

P1015482

Inside Building (looking northeast)

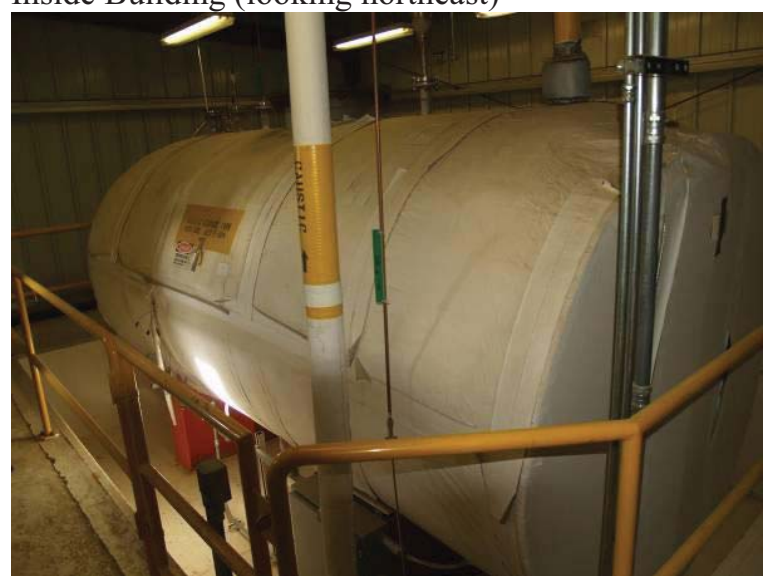

P1015483

Caustic Pump

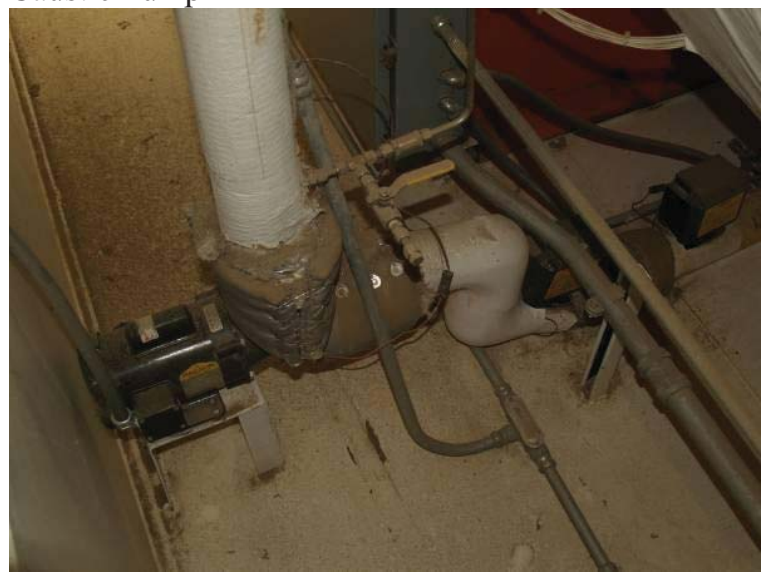

P1015484

Caustic Storage Tank and Pit (looking southwest)

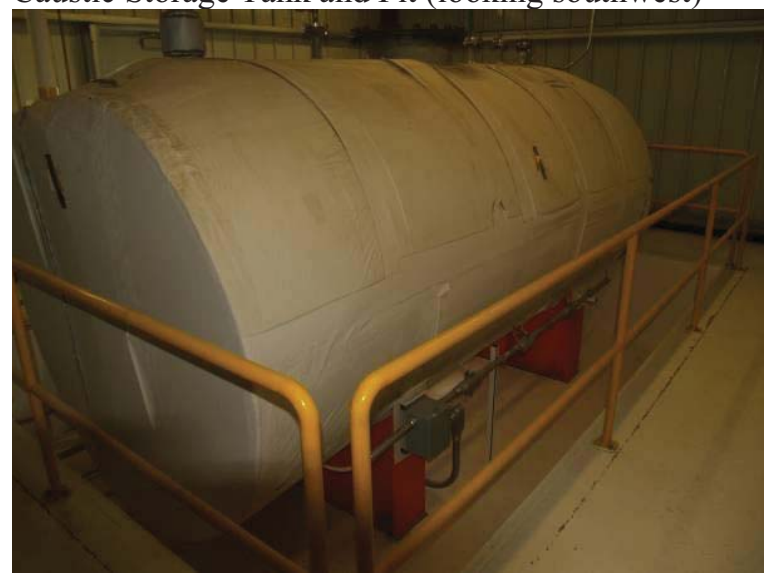


P1015485

Caustic Storage Tank and Pit (looking southeast)

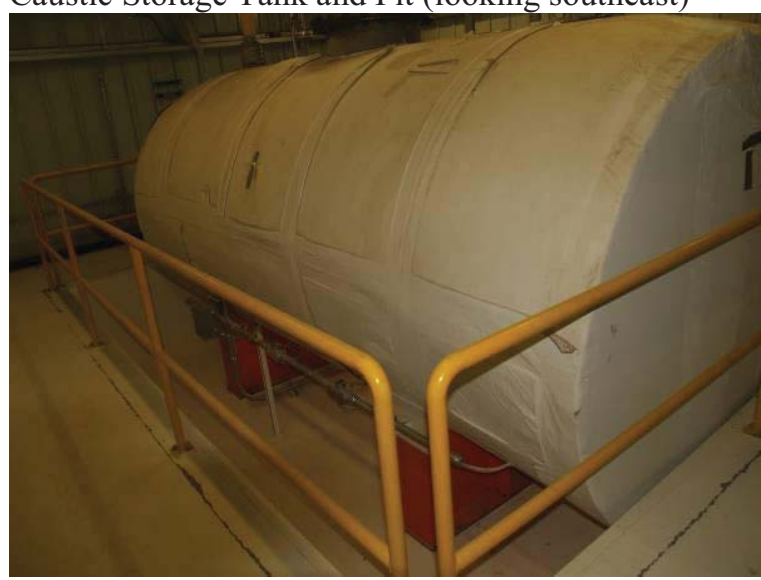

P1015486

P1015487
Caustic Storage Tank and Pit (looking northwest)

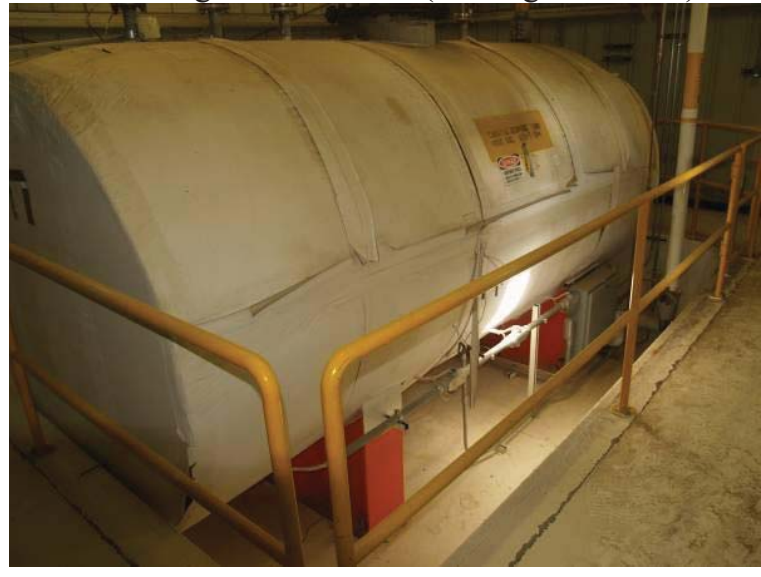

Overhead Caustic Piping (looking northwest)

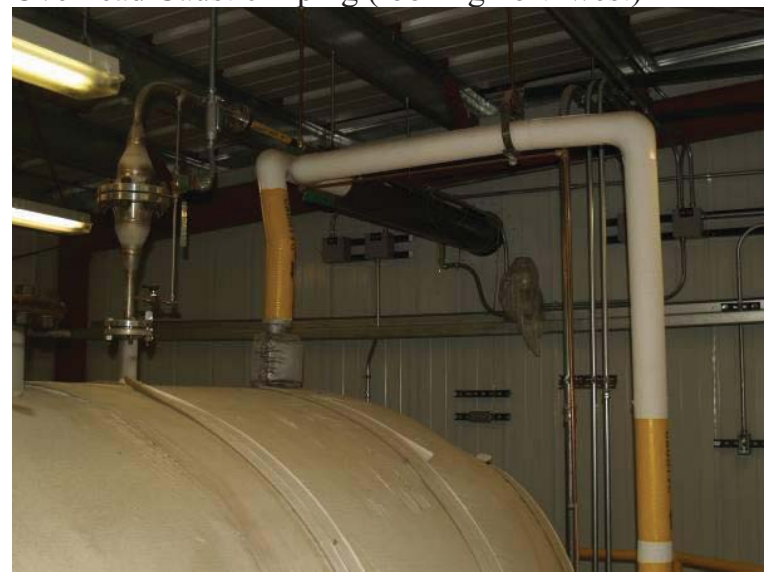


Appendix D

\section{Radiological Control Survey Maps}




\section{VSDS Standard Map Survey Report \\ Survey M-20091014-30}

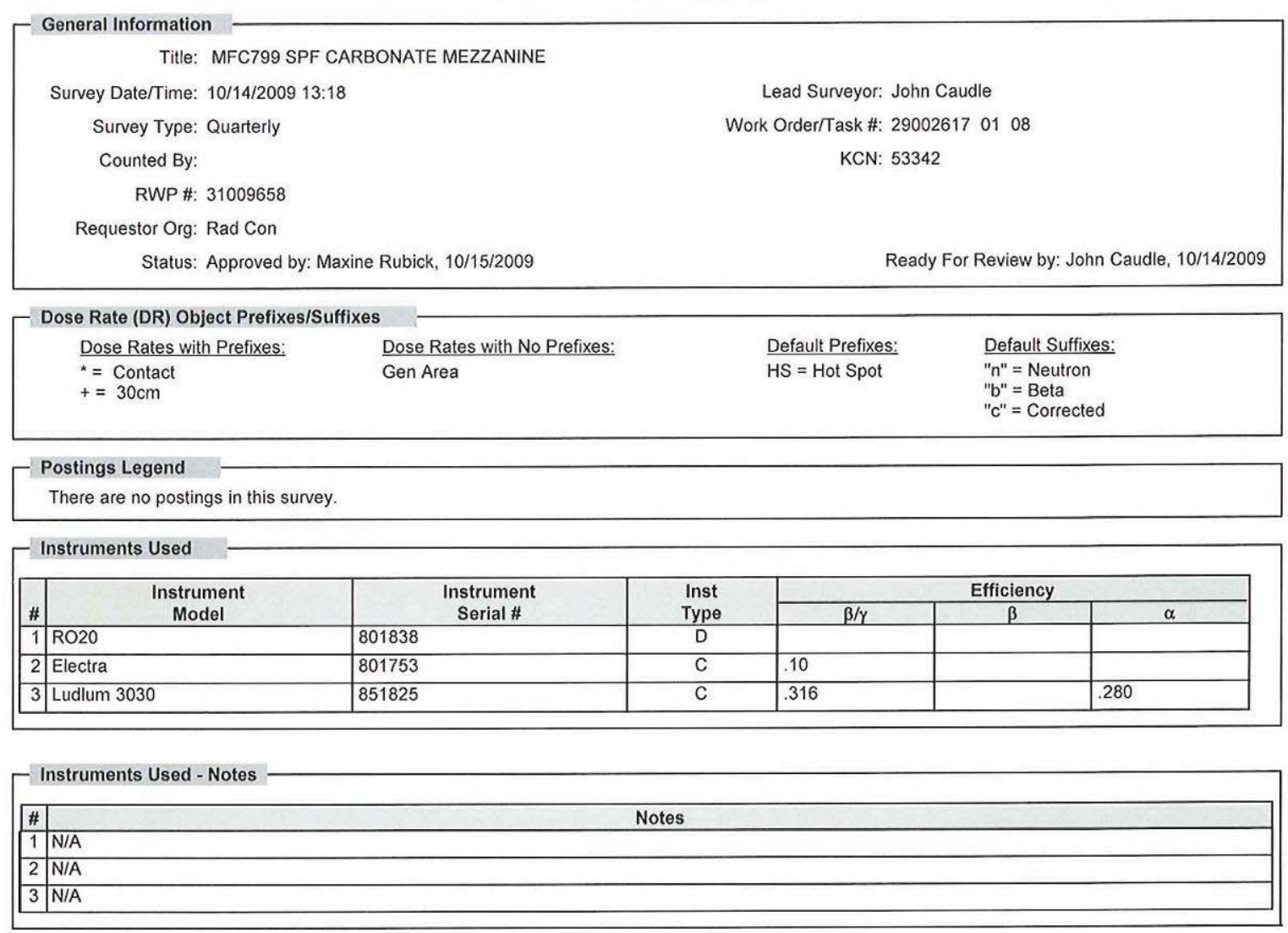

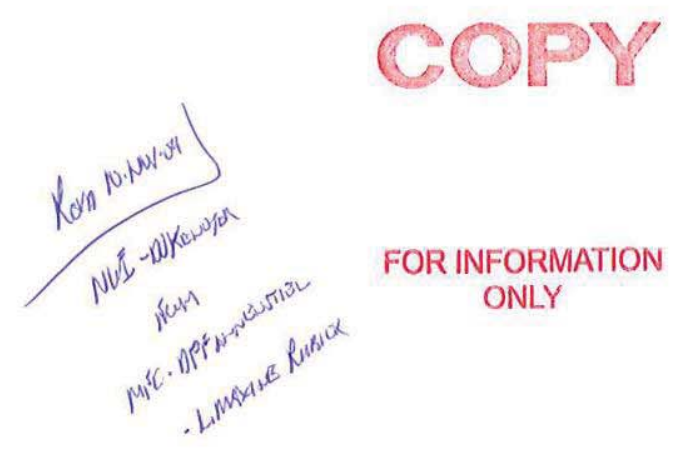

Document \#: N/A

Reference: MCP-139 - 0 pages

Survey \#: M-20091014-30 - Printed On: 11/10/2009 10:17

Page 1 of 3 


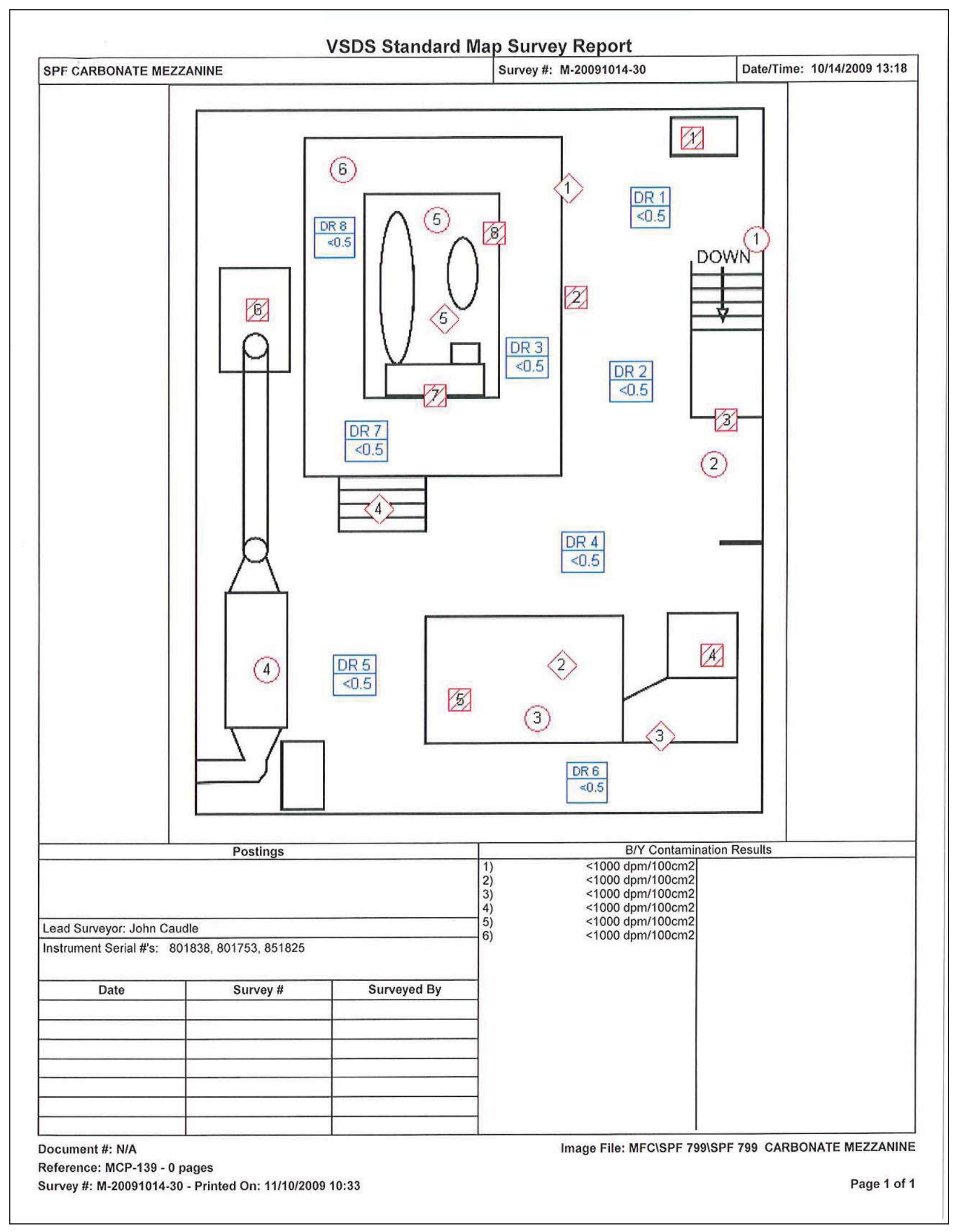




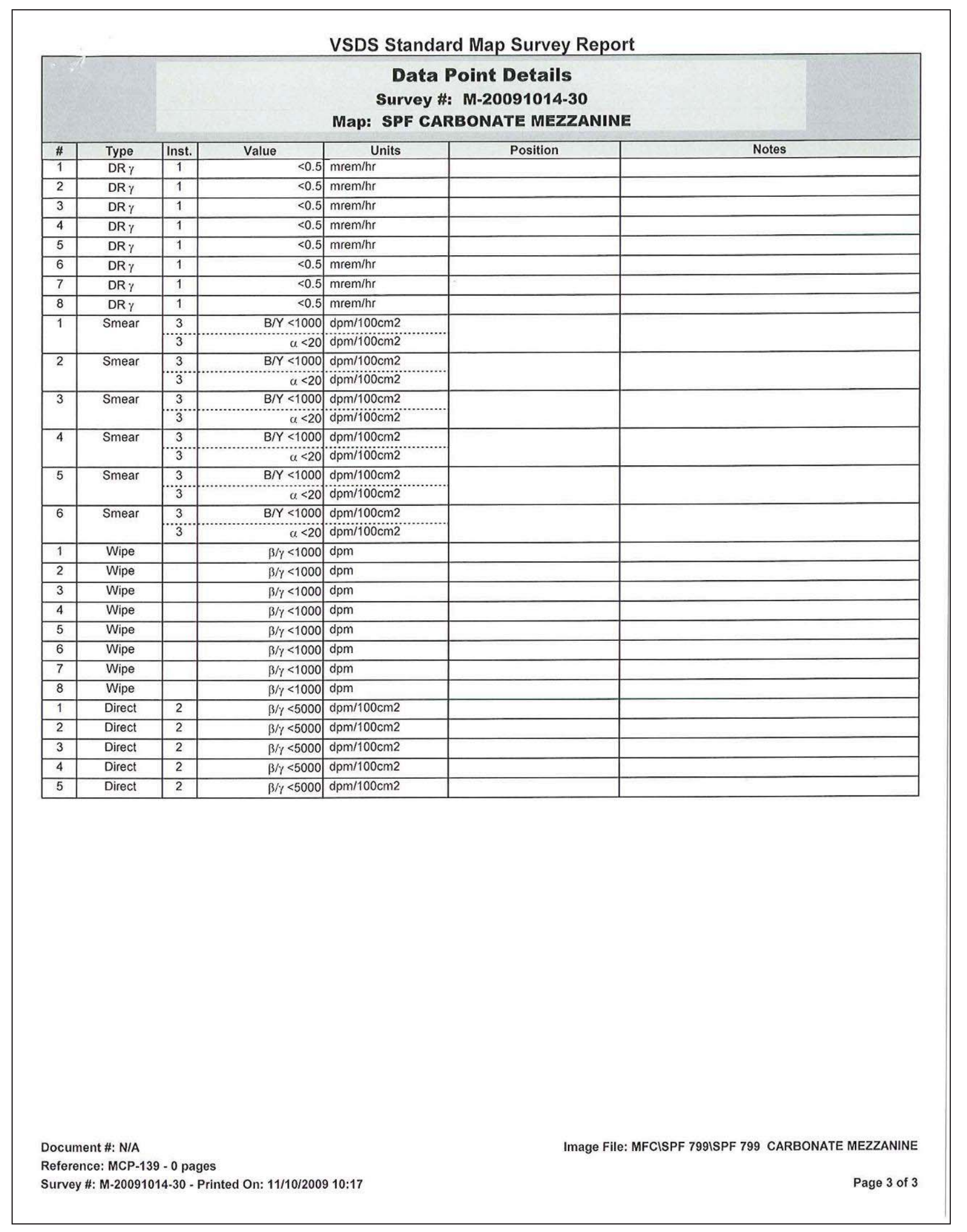




\section{VSDS Standard Map Survey Report \\ Survey M-20091014-29}

- General Information

Title: MFC799 SPF CARBONATE MAIN FLOOR AREA

Survey Date/Time: 10/14/2009 13:07

Lead Surveyor: John Caudle

Survey Type: Quarterly

Work Order/Task \#: 290026170108

Counted By:

KCN: 53342

RWP \#: 31009658

Requestor Org: Rad Con

Status: Approved by: Maxine Rubick, 10/15/2009

Ready For Review by: John Caudle, 10/14/2009

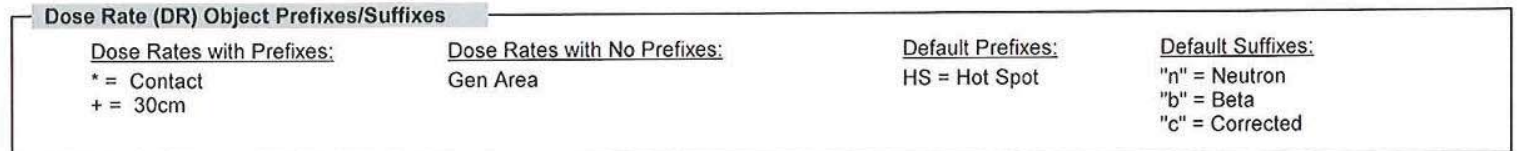

Postings Legend

RMA=Radioactive Material Area

RMSA=Rad Material Storage Area

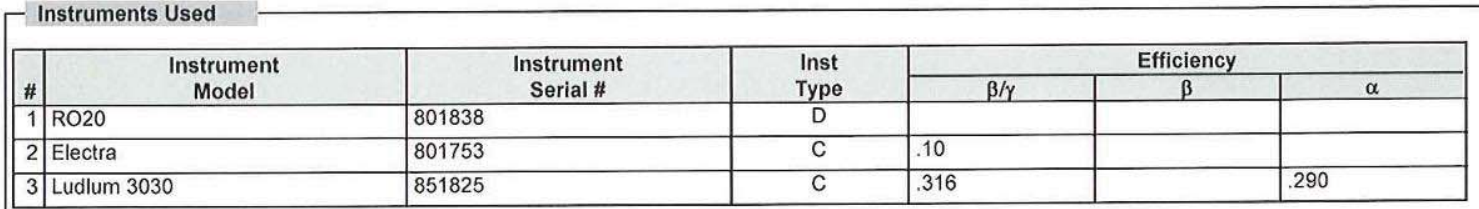

- Instruments Used - Notes

\# $\quad$ Notes

\begin{tabular}{|l|l}
\hline 1 & N/A \\
\hline & 2
\end{tabular}

2 N/A

\begin{tabular}{|l|l|}
\hline 3 & N/A \\
\hline
\end{tabular}

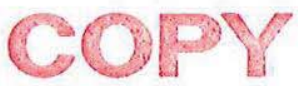

FOR INFORMATION

ONLY

Document \#: N/A

Reference: MCP-139 - 0 pages

Survey \#: M-20091014-29 - Printed On: 11/10/2009 10:18 


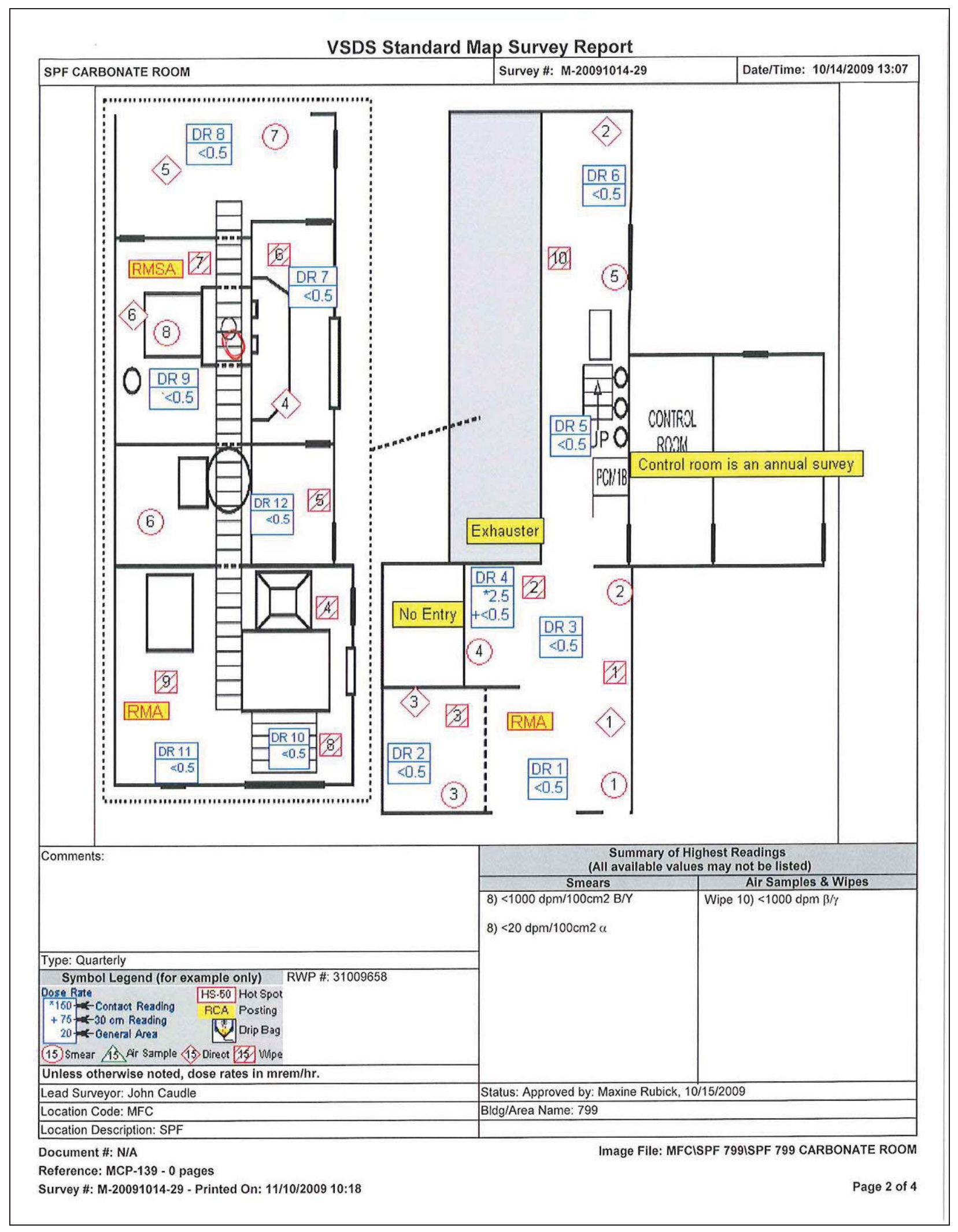




\begin{tabular}{|c|c|c|c|c|c|c|}
\hline \multicolumn{7}{|c|}{ VSDS Standard Map Survey Report } \\
\hline \multicolumn{7}{|c|}{$\begin{array}{c}\text { Data Point Details } \\
\text { Survey \#: M-20091014-29 } \\
\text { Map: SPF CARBONATE ROOM }\end{array}$} \\
\hline$\#$ & Type & Inst. & Value & \begin{tabular}{|r|} 
Units \\
\end{tabular} & Position & Notes \\
\hline 1 & $\mathrm{DR} \gamma$ & 1 & $<0.5$ & \begin{tabular}{|l|}
$\mathrm{mrem} / \mathrm{hr}$ \\
\end{tabular} & & \\
\hline 2 & DR $\gamma$ & 1 & $<0.5$ & mrem/hr & & \\
\hline 3 & $\mathrm{DR} \gamma$ & 1 & $<0.5$ & \begin{tabular}{|l|}
$\mathrm{mrem} / \mathrm{hr}$ \\
\end{tabular} & & \\
\hline \multirow[t]{2}{*}{4} & \multirow[t]{2}{*}{$\mathrm{DR} \gamma$} & 1. & $\begin{array}{r}* \\
* 2.5 \\
\ldots \ldots 2\end{array}$ & \begin{tabular}{|l}
$\mathrm{mrem} / \mathrm{hr}$ \\
$\mathrm{nnem}$
\end{tabular} & & \\
\hline & & 1 & $+<0.5$ & mrem/hr & & \\
\hline 5 & $\mathrm{DR} \gamma$ & 1 & $<0.5$ & mrem/hr & & \\
\hline 6 & DR $\gamma$ & 1 & $<0.5$ & mrem/hr & & \\
\hline 7 & DR $\gamma$ & 1 & $<0.5$ & mrem/hr & & \\
\hline 8 & $\mathrm{DR} \gamma$ & 1 & $<0.5$ & $\mathrm{mrem} / \mathrm{hr}$ & & \\
\hline 9 & $\mathrm{DR} \gamma$ & 1 & $<0.5$ & $\mathrm{mrem} / \mathrm{hr}$ & & \\
\hline 10 & DR $\gamma$ & 1 & $<0.5$ & mrem/hr & & \\
\hline 11 & DR $\gamma$ & 1 & $<0.5$ & mrem/hr & & \\
\hline 12 & $\mathrm{DR}_{\gamma}$ & 1 & $<0.5$ & mrem/hr & & \\
\hline \multirow[t]{2}{*}{1} & \multirow[t]{2}{*}{ Smear } & 3 & $\mathrm{~B} / \mathrm{Y}<1000$ & $\begin{array}{l}\mathrm{dpm} / 100 \mathrm{~cm} 2 \\
\end{array}$ & & \\
\hline & & 3 & $\alpha<20$ & $\mathrm{dpm} / 100 \mathrm{~cm} 2$ & & \\
\hline \multirow[t]{2}{*}{2} & \multirow[t]{2}{*}{ Smear } & 3 & $\mathrm{~B} / \mathrm{Y}<1000$ & $\mathrm{dpm} / 100 \mathrm{~cm} 2$ & & \\
\hline & & 3 & $\alpha<20$ & $\mathrm{dpm} / 100 \mathrm{~cm} 2$ & & \\
\hline \multirow[t]{2}{*}{3} & \multirow[t]{2}{*}{ Smear } & 3 & $B / Y<1000$ & $\mathrm{dpm} / 100 \mathrm{~cm} 2$ & & \\
\hline & & 3 & $a<20$ & $\mathrm{dpm} / 100 \mathrm{~cm} 2$ & & \\
\hline \multirow[t]{2}{*}{4} & \multirow[t]{2}{*}{ Smear } & 3 & $\mathrm{~B} / \mathrm{Y}<1000$ & $\mathrm{dpm} / 100 \mathrm{~cm} 2$ & & \\
\hline & & 3 & $\alpha<20$ & $\mathrm{dpm} / 100 \mathrm{~cm} 2$ & & \\
\hline \multirow[t]{2}{*}{5} & \multirow[t]{2}{*}{ Smear } & 3 & $\mathrm{~B} / \mathrm{Y}<1000$ & $\mathrm{dpm} / 100 \mathrm{~cm} 2$ & & \\
\hline & & 3 & $\alpha<20$ & $\mathrm{dpm} / 100 \mathrm{~cm} 2$ & & \\
\hline \multirow[t]{2}{*}{6} & \multirow[t]{2}{*}{ Smear } & 3 & $\mathrm{~B} / \mathrm{Y}<1000$ & $\mathrm{dpm} / 100 \mathrm{~cm} 2$ & & \\
\hline & & 3 & $\alpha<20$ & $\mathrm{dpm} / 100 \mathrm{~cm} 2$ & & \\
\hline \multirow[t]{2}{*}{7} & Smear & 3 & $\mathrm{~B} / \mathrm{Y}<1000$ & $\mathrm{dpm} / 100 \mathrm{~cm} 2$ & & \\
\hline & & 3 & $\alpha<20$ & $\mathrm{dpm} / 100 \mathrm{~cm} 2$ & & \\
\hline 8 & Smear & 3 & $\mathrm{~B} / \mathrm{Y}<1000$ & $\mathrm{dpm} / 100 \mathrm{~cm} 2$ & & \\
\hline & & 3 & $\alpha<20$ & dpm $1100 \mathrm{~cm} 2$ & & \\
\hline 1 & Wipe & & $\beta / \gamma<1000$ & dpm & & \\
\hline 2 & Wipe & & $\beta / \gamma<1000$ & $\mathrm{dpm}$ & & \\
\hline 3 & Wipe & & $\beta / \gamma<1000$ & $\mathrm{dpm}$ & & \\
\hline 4 & Wipe & & $\beta / \gamma<1000$ & $\mathrm{dpm}$ & & \\
\hline 5 & Wipe & & $\beta / \gamma<1000$ & $\mathrm{dpm}$ & & \\
\hline 6 & Wipe & & $\beta / \gamma<1000$ & dpm & & \\
\hline 7 & Wipe & & $\beta / \gamma<1000$ & $\mathrm{dpm}$ & & \\
\hline 8 & Wipe & & $\beta / \gamma<1000$ & $\mathrm{dpm}$ & & \\
\hline 9 & Wipe & & $\beta / \gamma<1000$ & $\mathrm{dpm}$ & & \\
\hline 10 & Wipe & & $\beta / \gamma<1000$ & dpm & & \\
\hline 1 & Direct & 2 & $\beta / \gamma<5000$ & $\mathrm{dpm} / 100 \mathrm{~cm} 2$ & & \\
\hline 2 & Direct & 2 & $\beta / \gamma<5000$ & $\mathrm{dpm} / 100 \mathrm{~cm} 2$ & & \\
\hline 3 & Direct & 2 & $\beta / \gamma<5000$ & $\mathrm{dpm} / 100 \mathrm{~cm} 2$ & & \\
\hline 4 & Direct & 2 & $\beta / \gamma<5000$ & $\mathrm{dpm} / 100 \mathrm{~cm} 2$ & & \\
\hline 5 & Direct & 2 & $\beta / \gamma<5000$ & $\mathrm{dpm} / 100 \mathrm{~cm} 2$ & & \\
\hline 6 & Direct & 2 & $\beta / \gamma<5000$ & $\mathrm{dpm} / 100 \mathrm{~cm} 2$ & & \\
\hline & Text & & $\begin{array}{l}\text { Control room is an } \\
\text { annual survey }\end{array}$ & & & \\
\hline & Text & & Exhauster & & & \\
\hline & Text & & No Entry & & & \\
\hline & Posting & & RMA & & & \\
\hline Docu & it \#: N/A & & & & & ge File: MFCISPF 799ISPF 799 CARBONATE ROOM \\
\hline Refer & : MCP-1 & $-0 \mathrm{pa}$ & & & & \\
\hline Surve & M-20091 & $4-29$ - & Printed On: $11 / 10 / 200$ & $910: 18$ & & Page 3 of 4 \\
\hline
\end{tabular}




\begin{tabular}{|c|c|c|c|c|c|c|}
\hline \multicolumn{7}{|c|}{ VSDS Standard Map Survey Report } \\
\hline \multicolumn{7}{|c|}{$\begin{array}{c}\text { Data Point Details } \\
\text { Survey \#: M-20091014-29 } \\
\text { Map: SPF CARBONATE ROOM }\end{array}$} \\
\hline$\#$ & Type & Inst. & Value & Units & Position & Notes \\
\hline & Posting & & RMA & & & \\
\hline & Posting & & RMSA & & & \\
\hline
\end{tabular}




\section{VSDS Standard Map Survey Report \\ Survey M-20091014-24}

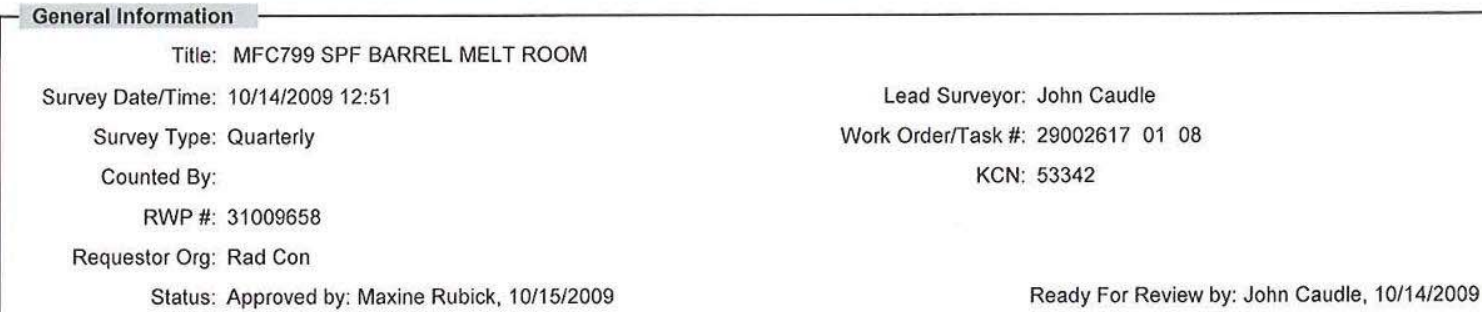

Status: Approved by: Maxine Rubick, 10/15/2009

Lead Surveyor: John Caudle

Work Order/Task \#: 290026170108

KCN: 53342

Ready For Review by: John Caudle, 10/14/2009

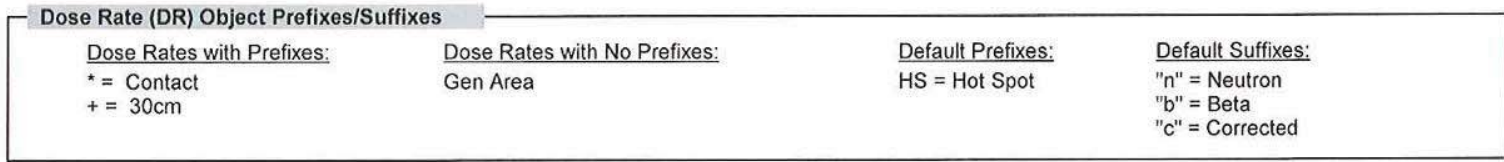

- Postings Legend

RMA=Radioactive Material Area

\begin{tabular}{|c|c|c|c|c|c|c|}
\hline \multirow[b]{2}{*}{$\#$} & \multirow{2}{*}{$\begin{array}{c}\text { Instrument } \\
\text { Model }\end{array}$} & \multirow{2}{*}{$\begin{array}{c}\text { Instrument } \\
\text { Serial \# }\end{array}$} & \multirow{2}{*}{$\begin{array}{l}\text { Inst } \\
\text { Type }\end{array}$} & \multicolumn{3}{|c|}{ Efficiency } \\
\hline & & & & $\beta / \gamma$ & $\beta$ & $\alpha$ \\
\hline 1 & $\mathrm{RO} 20$ & 801838 & D & & & \\
\hline 2 & Electra & 801753 & C & .10 & & \\
\hline 3 & Ludlum 3030 & 851825 & C & .317 & & .290 \\
\hline
\end{tabular}

- Instruments Used - Notes

\begin{tabular}{l|ll}
\hline$\#$ & Notes
\end{tabular}

1 N/A

Notes

\begin{tabular}{l|l}
\hline & N/A \\
\hline 3 & N/A
\end{tabular}

\begin{tabular}{l|l|l}
\hline 3 & NIA \\
\hline
\end{tabular} 


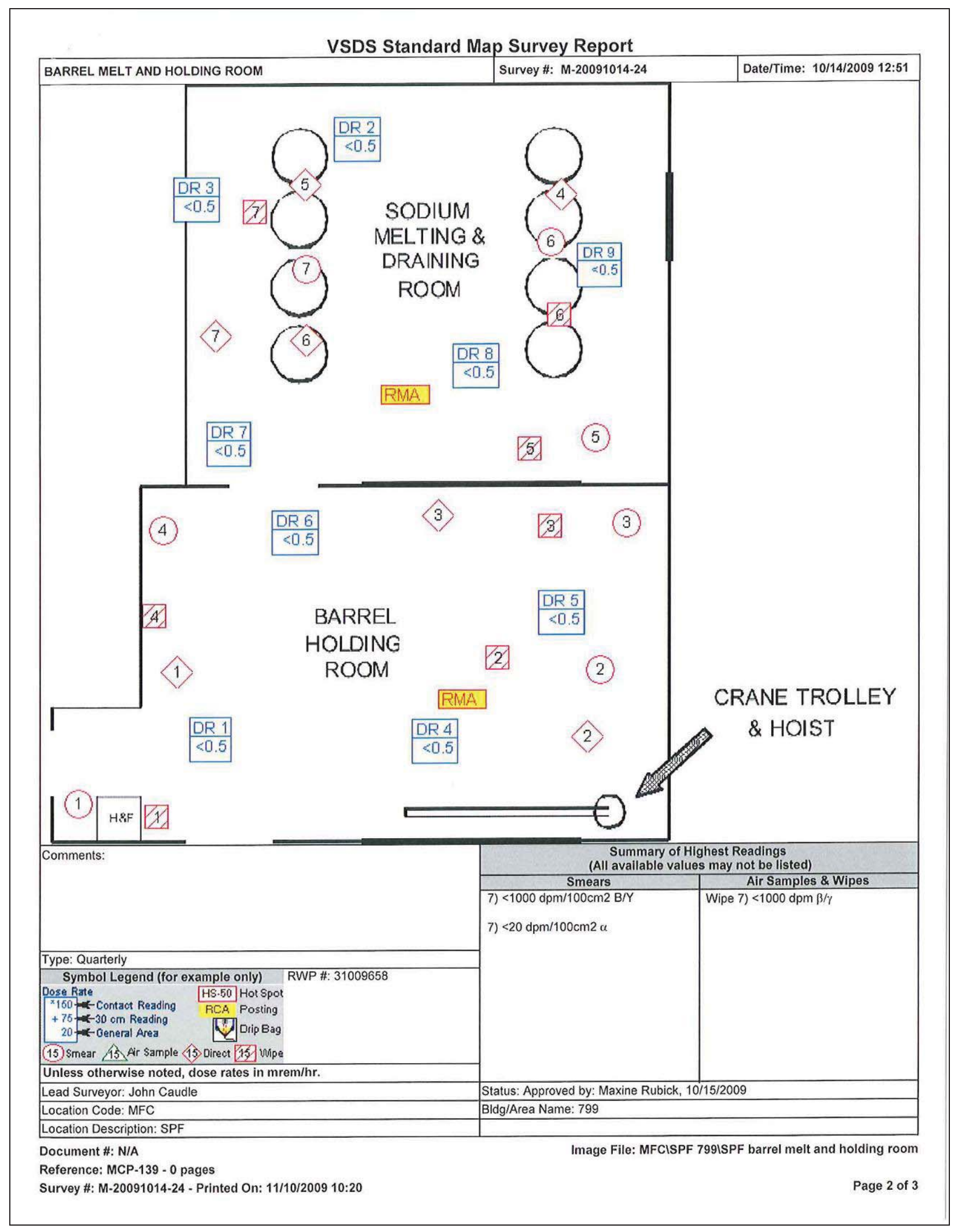




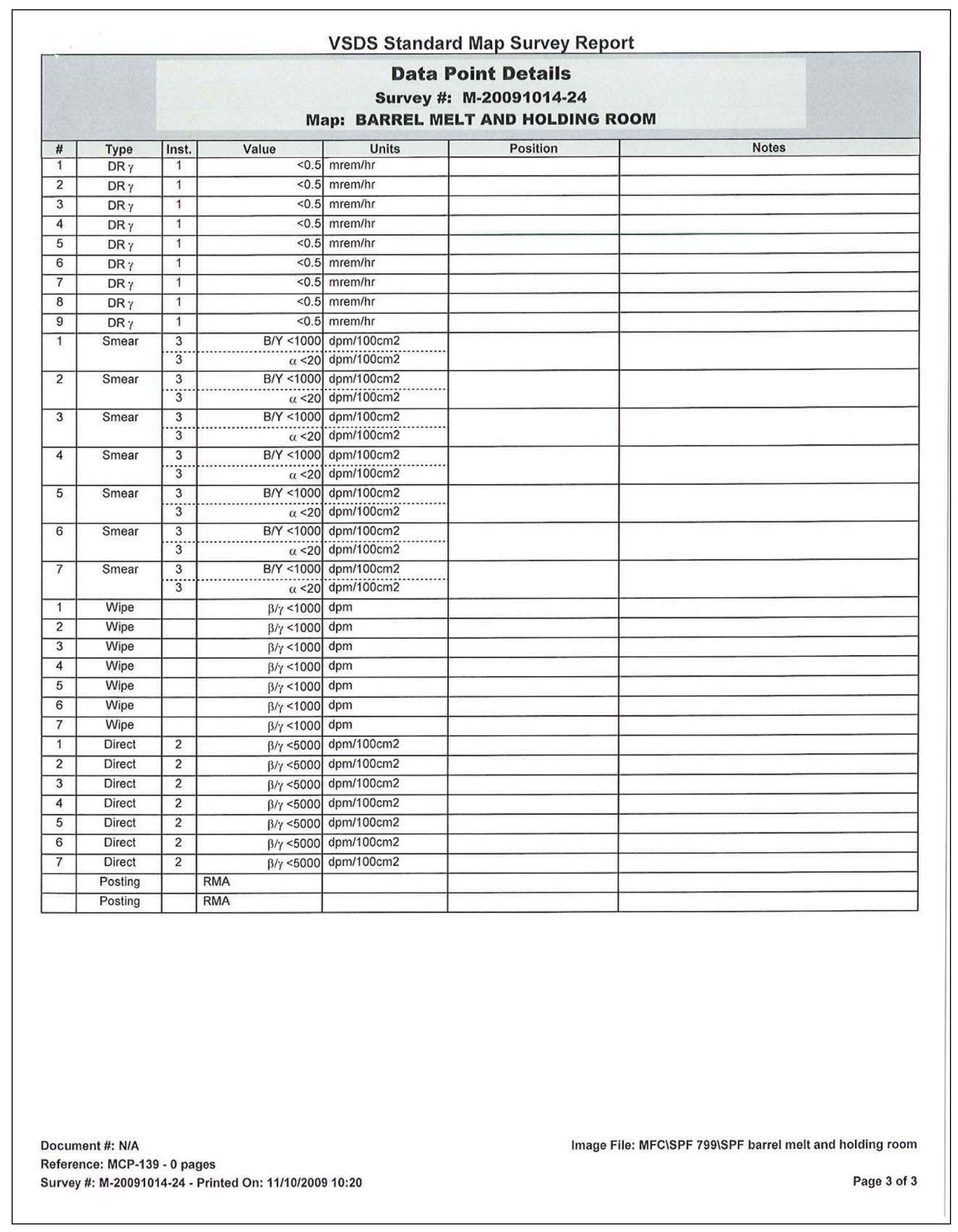




\section{VSDS Standard Map Survey Report}

Survey M-20091014-20

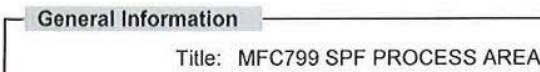

Title: MFC799 SPF PROCESS AREA

Survey Date/Time: 10/14/2009 12:44

Survey Type: Quarterly

Counted By:

Lead Surveyor: John Caudle

Work Order/Task \#: N/A

KCN: 53342

RWP \#: 31009658

Requestor Org: RAD CON

Status: Approved by: Maxine Rubick, 10/15/2009

Ready For Review by: John Caudle, 10/14/2009

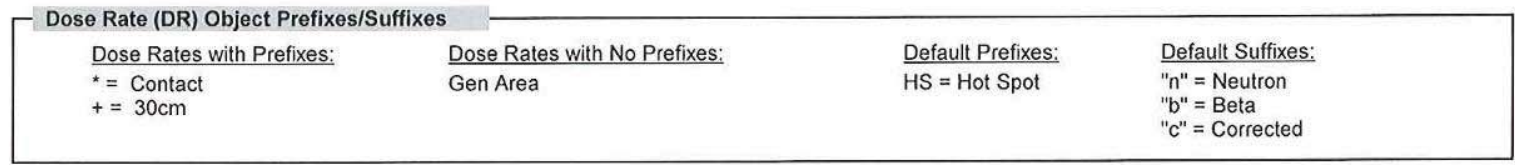

- Postings Legend

RMA $=$ Radioactive Material Area

\begin{tabular}{|c|c|c|c|c|c|c|}
\hline \multirow[b]{2}{*}{ \# } & \multirow{2}{*}{$\begin{array}{c}\text { Instrument } \\
\text { Model }\end{array}$} & \multirow{2}{*}{$\begin{array}{c}\text { Instrument } \\
\text { Serial \# }\end{array}$} & \multirow{2}{*}{$\begin{array}{l}\text { Inst } \\
\text { Type }\end{array}$} & \multicolumn{3}{|c|}{ Efficiency } \\
\hline & & & & $\beta / \gamma$ & $\beta$ & $\alpha$ \\
\hline 1 & RO20 & 801838 & D & & & \\
\hline 2 & Electra & 801753 & C & .10 & & \\
\hline 3 & Ludlum 3030 & 851825 & C & .317 & & .290 \\
\hline
\end{tabular}

- Instruments Used - Notes

\# $\quad$ Notes

\begin{tabular}{l|l}
$\# 1$ & N/A \\
\hline & N/A
\end{tabular}

2 N/A

\begin{tabular}{|l|l|}
\hline 3 & N/A \\
\hline
\end{tabular}

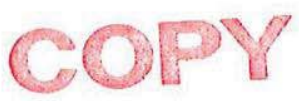

FOR INFORMATION

ONLY 


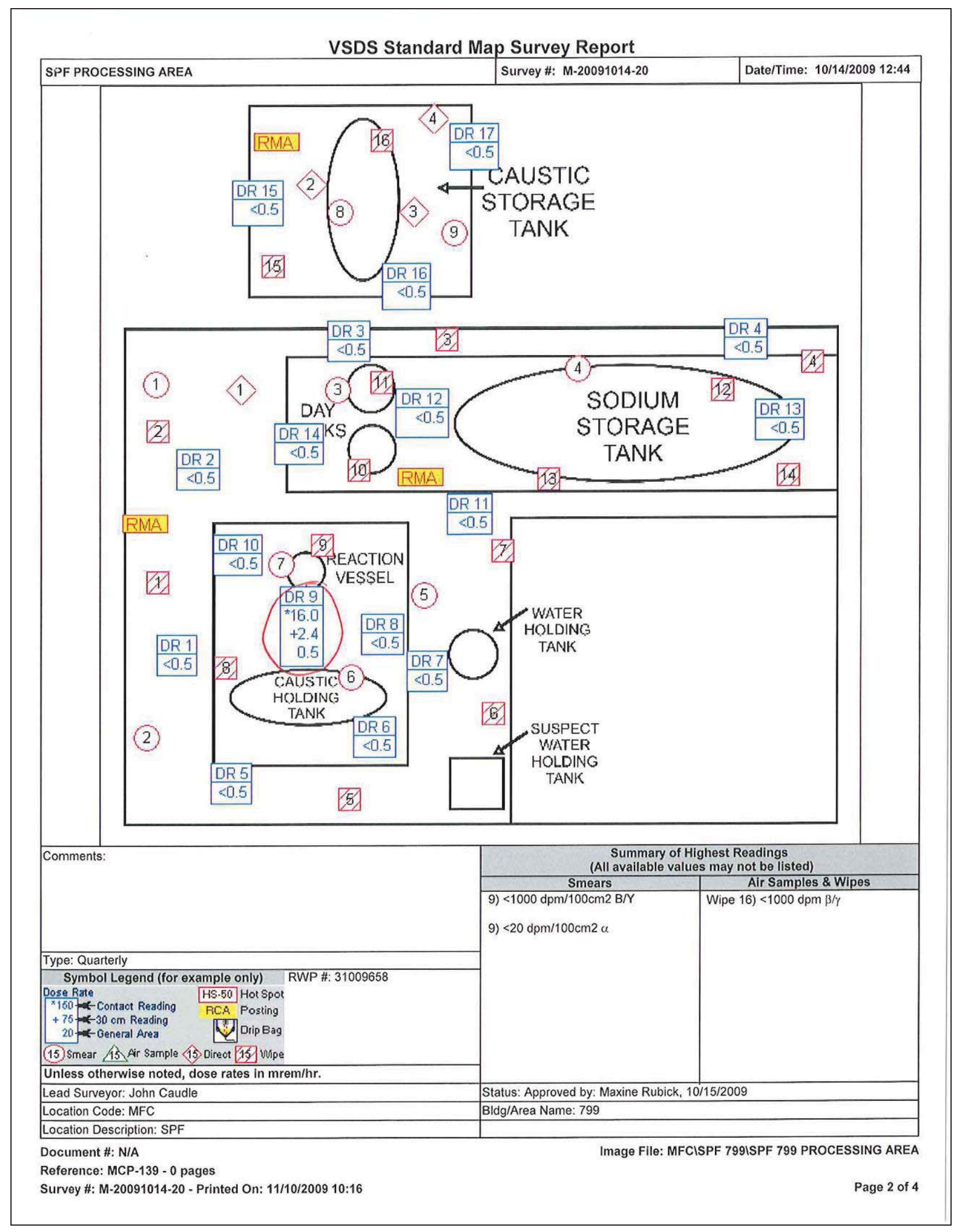




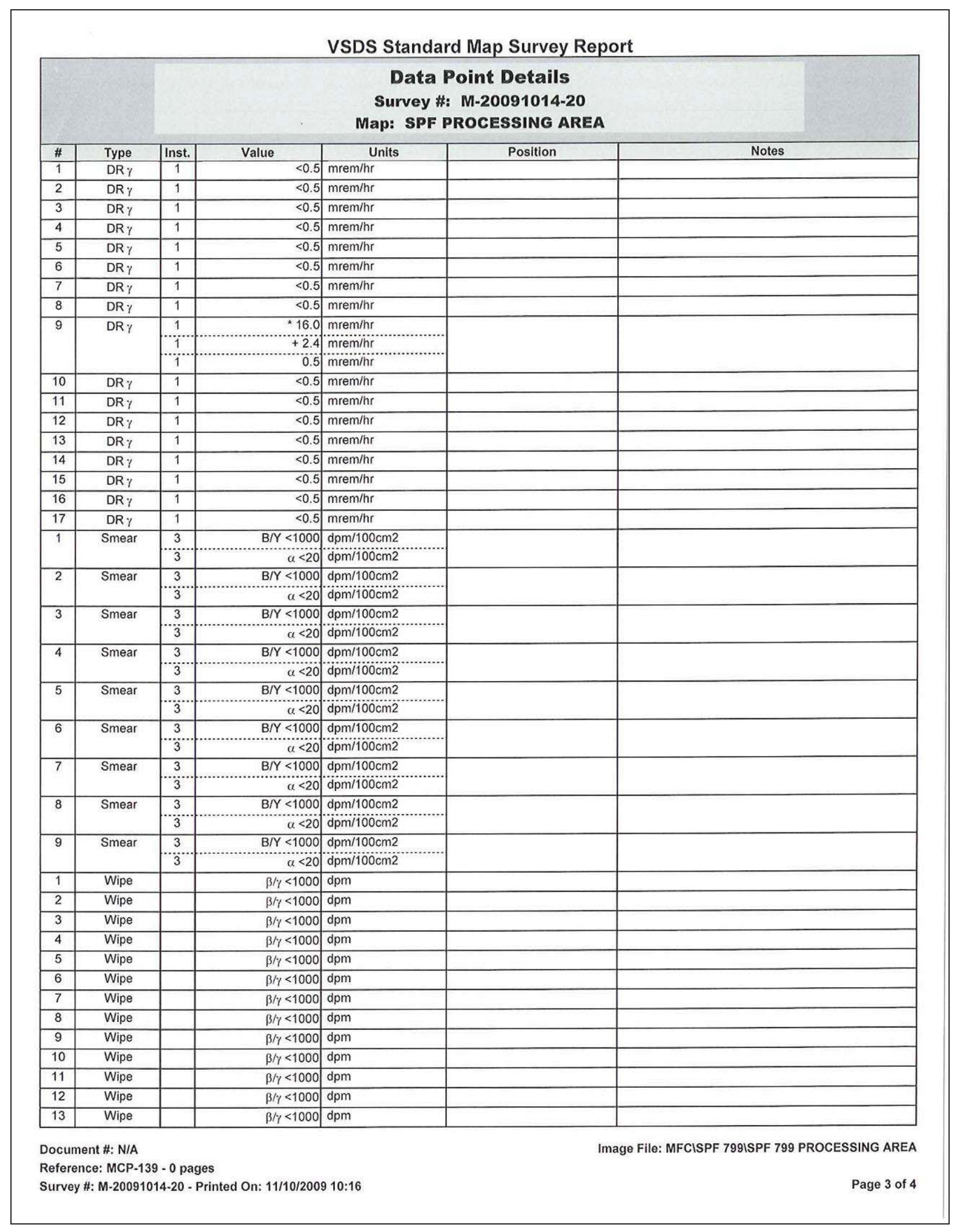




\section{VSDS Standard Map Survey Report}

\begin{tabular}{|c|c|c|c|c|c|c|}
\hline \multirow{2}{*}{$\#$} & \multicolumn{6}{|c|}{$\begin{array}{c}\text { Data Point Details } \\
\text { Survey \#: M-20091014-20 } \\
\text { Map: SPF PROCESSING AREA }\end{array}$} \\
\hline & Type & Inst. & \begin{tabular}{l|l} 
Value \\
\end{tabular} & Units & Position & Notes \\
\hline 14 & Wipe & & $\beta / \gamma<1000$ & $\mathrm{dpm}$ & & \\
\hline 15 & Wipe & & $\beta / \gamma<1000$ & dpm & & \\
\hline 16 & Wipe & & $\beta / \gamma<1000$ & $\mathrm{dpm}$ & & \\
\hline 1 & Direct & 2 & $\beta / \gamma<5000$ & $\mathrm{dpm} / 100 \mathrm{~cm} 2$ & & \\
\hline 2 & Direct & 2 & $\beta / \gamma<5000$ & $\mathrm{dpm} / 100 \mathrm{~cm} 2$ & & \\
\hline 3 & Direct & 2 & $\beta / \gamma<5000$ & $\mathrm{dpm} / 100 \mathrm{~cm} 2$ & & \\
\hline 4 & Direct & 2 & $\beta / \gamma<5000$ & $\mathrm{dpm} / 100 \mathrm{~cm} 2$ & & \\
\hline & Posting & & RMA & & & \\
\hline & Posting & & RMA & & & \\
\hline & Posting & & RMA & & & \\
\hline
\end{tabular}


Appendix E

\section{Detailed Cost Estimate}




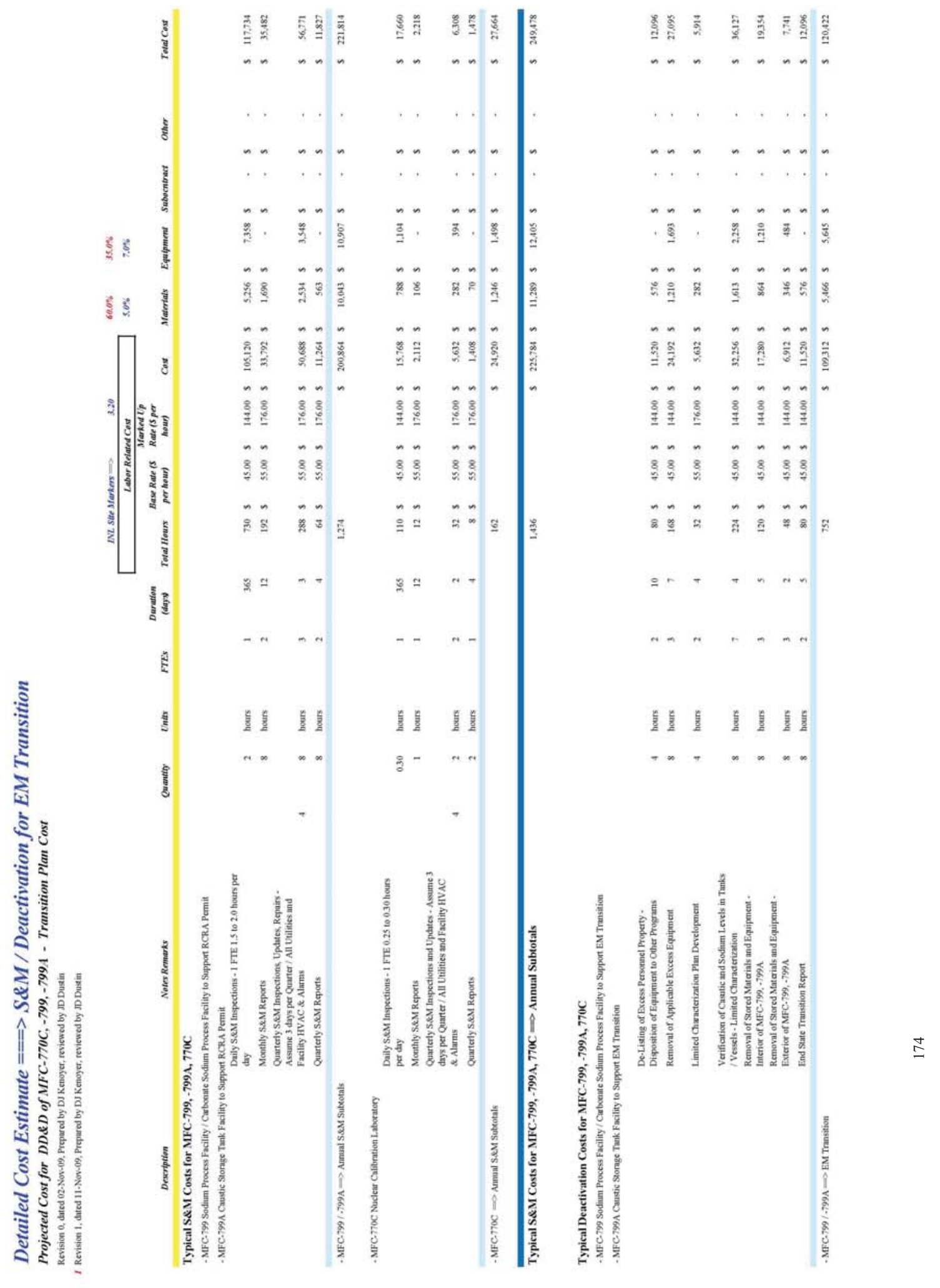




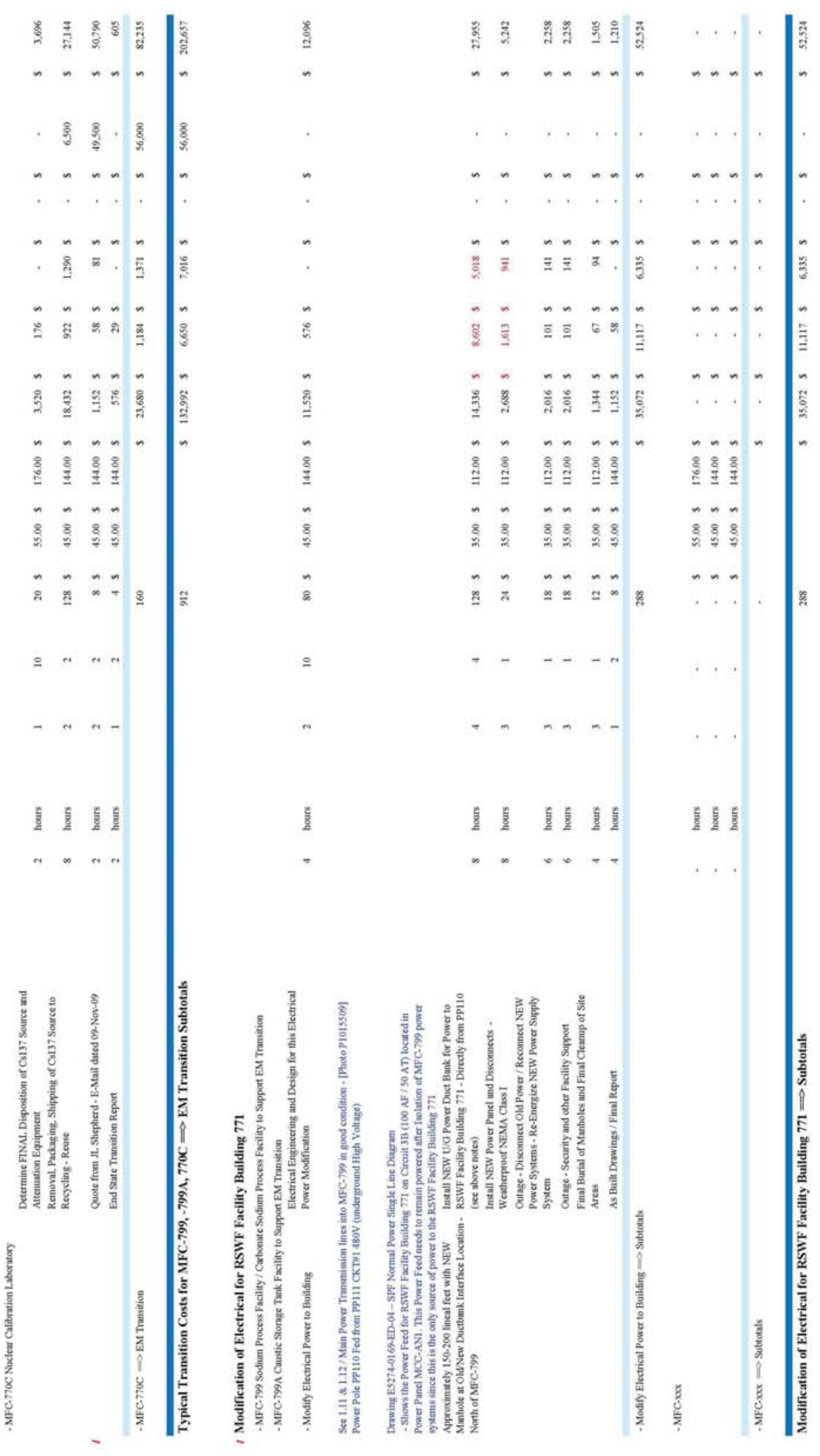

